A History of Force Feeding 

Ian Miller

\section{A History of Force Feeding}

\section{Hunger Strikes, Prisons and Medical Ethics, 1909-1974}

\section{palgrave macmillan}

This book is distributed under the terms of the Creative Commons Attribution 4.0 International License (http://creativecommons.org/ licenses $/$ by $/ 4.0 /$ ), which permits use, duplication, adaptation, distribution and reproduction in any medium or format, as long as you give appropriate credit to the original author(s) and the source, provide a link to the Creative Commons license and indicate if changes were made.

The images or other third party material in this book are included in the work's Creative Commons license, unless indicated otherwise in the credit line; if such material is not included in the work's Creative Commons license and the respective action is not permitted by statutory regulation, users will need to obtain permission from the license holder to duplicate, adapt or reproduce the material. 
Ian Miller

Ulster University

Coleraine, United Kingdom

ISBN 978-3-319-31112-8

DOI $10.1007 / 978-3-319-31113-5$

ISBN 978-3-319-31113-5 (eBook)

Library of Congress Control Number: 2016941754

(C) The Editor(s) (if applicable) and The Author(s) 2016

Open Access This book is distributed under the terms of the Creative Commons Attribution 4.0 International License (http://creativecommons.org/licenses/by/4.0/), which permits use, duplication, adaptation, distribution and reproduction in any medium or format, as long as you give appropriate credit to the original author(s) and the source, provide a link to the Creative Commons license and indicate if changes were made.

The images or other third party material in this book are included in the work's Creative Commons license, unless indicated otherwise in the credit line; if such material is not included in the work's Creative Commons license and the respective action is not permitted by statutory regulation, users will need to obtain permission from the license holder to duplicate, adapt or reproduce the material.

The use of general descriptive names, registered names, trademarks, service marks, etc. in this publication does not imply, even in the absence of a specific statement, that such names are exempt from the relevant protective laws and regulations and therefore free for general use. The publisher, the authors and the editors are safe to assume that the advice and information in this book are believed to be true and accurate at the date of publication. Neither the publisher nor the authors or the editors give a warranty, express or implied, with respect to the material contained herein or for any errors or omissions that may have been made.

Printed on acid-free paper

This Palgrave Macmillan imprint is published by Springer Nature

The registered company is Springer International Publishing AG Switzerland 


\section{ACKNOWLEDGEMENTS}

This study began life in Manchester during 2009 where I first began to write about suffragette hunger strikes and the complexities of prison medicine. I developed further aspects of the research while employed at University College Dublin between 2009 and 2013 where I became intrigued by Irish republican force-feedings. The remainder of this study was kindly supported by a Wellcome Trust Research Fellowship in Medical Humanities undertaken at Ulster University in Northern Ireland, a natural home for a book on hunger strikes to be written.

Due to the long gestation of the project, I have accumulated numerous debts. I am particularly grateful to Leanne McCormick for her support of this project and my other ideas during my time as a researcher at the Centre for the History of Medicine in Ireland at Ulster University. She provided a warm, supportive working environment alongside Andrew Sneddon, Greta Jones, and Donald MacRaild. Further afield, I am grateful to David Nicholl for his enthusiasm for my project. The project has resulted in a number of conferences and public engagement initiatives. I am particularly grateful to Ciara Breathnach and Laura McAtackney for their help in encouraging me to find ways to engage with public audiences. In particular, I would like to thank Dr Berry Beaumont whose campaigns against force-feeding in the 1970s form part of the book.

I am also grateful for the various comments and suggestions from audience members at conferences and events at Birkbeck College, Maynooth University, Ulster University, Universiteit van Amsterdam, Queen's University Belfast, Glasnevin Cemetary (Dublin), University of Liverpool, Trinity College Dublin, Boston College (Dublin), Uppsala Universitet, 
King's College London, and Universität Zürich. I also wish to acknowledge the helpfulness of the staff at the various archives in which this research was conducted: John Rylands Library (University of Manchester); National Archives, Kew; National Library of Ireland; National Archives of Ireland; Public Record Office of Northern Ireland; the Quaker Peace Library; and Linen Hall Library, Belfast. I wish to acknowledge the BBC archives (based at Ulster Folk Museum) for allowing me to access and use audio-visual material. I am also grateful to Greta Jones who allowed me to access oral history material relating to the Troubles held at Ulster University. My research also benefitted from a period as a visiting research fellow at the Max Planck Institute for the History of Emotions.

Finally, I am indebted, as always to my family members: Kevin Miller, Pauline Miller, Sarah Miller, Katie Miller, and Miriam Trevor. 


\section{Contents}

1 Introduction 1

2 'A Prostitution of the Profession'?: The Ethical Dilemma of Suffragette Force-Feeding, 1909-14

3 'The Instrument of Death': Prison Doctors and Medical Ethics in Revolutionary-Period Ireland, c.1917

4 'A Few Deaths from Hunger Is Nothing': Experiencing Starvation in Irish Prisons, 1917-23

5 'I've Heard o' Food Queues, but This Is the First Time I've Ever Heard of a Feeding Queue!': Hunger Strikers, War, and the State, 1914-61

6 'I Would Have Gone on with the Hunger Strike, but Force-Feeding I Could Not Take': The Coercion of Hunger Striking Convict Prisoners, 1913-72 
viii CONTENTS

7 'An Experience Much Worse Than Rape': The End of Force-Feeding?

8 Conclusion

Bibliography

Index 


\section{List of Figures}

Fig. 2.1 Torturing women in prison: vote against the government

Fig. 2.2 A suffragette is force-fed in Holloway Prison

Fig. 6.1 Number of recorded hunger strike incidences responded to, and not responded to, with force-feeding in English Prisons, $1913-40$

Fig. 6.2 Number of times prisoners were force-fed on individual hunger strikes in English prisons, 1913-40

Fig. 6.3 Instruments used for force-feeding in English prisons, 1913-40

Fig. 6.4 English prisons in which incidences of force-feeding occurred, $1913-40$

Fig. 6.5 Recorded motivations for hunger striking in English prisons, $1913-40$ 


\section{Introduction}

In March 2013, a group of detainees at Guantánamo Bay Detention Camp, Cuba, went on hunger strike. At the height of their protest, 106 individuals were refusing to eat. For detainees incarcerated for over a decade without charge or trial, food refusal offered a potent way to rebel. Having been stripped of their capacity for political communication and placed in an institution that severely restricted personal freedom, the simple act of not eating allowed detainees to reassert control over their bodies. It granted autonomy and self-determination, posing a challenge to Guantánamo's disciplinary ethos. These hunger strikes were also highly political. By rejecting food, detainees openly defied the authority of the American government which had incarcerated them. They used their bodies as weapons, the last remaining resource available for remonstrating against adverse institutional conditions. ${ }^{1}$ In turn, the newsworthy nature of these protests drew international attention to allegations of institutional torture and violence seemingly supported by the Obama administration. The protestors knew that hunger strikes attract worldwide interest from journalists, human rights activists, politicians, ethicists, and doctors. They had posed a formidable moral question: Is it acceptable to allow a prisoner to starve to death?

Corpses present problems. A dead hunger striker can offer evidence of deplorable prison conditions. A death also goes some way towards validating dissident political perspectives. These, after all, had been worth dying for. Surely they must have some value? In the event of a death, less sympathetic 
observers always assert that hunger striking amounts to suicide and that the corpse was once a 'terrorist' intent on endangering the public with mindless violence. Why, they ask, should anyone care about a dead 'terrorist'? Yet, in politically charged circumstances, a lifeless hunger striker can swiftly transform into a martyr, a victim of political cruelty whose desperation led him/her to perform the unthinkable act of mutilating one's own body, entirely eradicating it in a grotesque act of disfigurement that (s)he could have halted at any time simply by eating.

Throughout the twentieth century, the emaciated bodies of hunger strikers provided a powerful symbol of determined resistance to aggressive states, not least in Ireland. Hunger strikers who died there did so for a national or collective cause, not to selfishly escape individual suffering or institutional misery. Their deaths were altruistic, selfless acts performed for the greater good of a national, religious, or political cause. ${ }^{2}$ They became 'good deaths', not suicides. In turn, death by hunger strike reshaped public perceptions of victim and aggressor. Bobby Sands provides a compelling example. Allowed to starve in a Northern Irish prison in 1981, the image of his emaciated body still raises claims of political intransigence and cruel, unnecessary treatment at the hands of Margaret Thatcher. Now valorised as an emblem of Irish self-sacrifice, Sands metamorphosed from 'terrorist' to martyr while the British state adopted the role of violent oppressor. Alternative perspectives on Sands' death exist, but this account predominates. $^{3}$ On a less ideological level, Sands' death sparked rioting throughout Northern Ireland, aroused international concern about the treatment of republican prisoners, and altered the trajectory of Northern Irish politics throughout the 1980s. Meanings became attached to Sands' withered body; his corpse became politically encoded. ${ }^{4}$ Both his hunger strike and death provided a public spectacle. ${ }^{5}$

For most governments, deaths from hunger strike are best avoided. But what alternatives are there? At Guantánamo, at the time of writing, detainees are being force-fed. Force-feeding (or forcible-feeding, as it was once termed) involves inserting a stomach tube into the mouth of a prisoner/patient which is then passed downwards through the throat and oesophagus before eventually arriving in the stomach. The passing of the tube causes most patients to gag, choke, and vomit over themselves. Once the patient has been calmed, liquid food is then poured into the top of the tube, and it descends into the stomach. Digestion is resumed. Forcefeeding can also be performed using a nasal tube. It shares similarities with artificial feeding, a procedure that keeps mentally ill patients who refuse 
to eat alive, as well as coma patients. ${ }^{6}$ Yet subtle differences exist. Unlike artificial feeding, force-feeding tends to be performed against the will of patients (mostly prisoners) who have decided not to eat. Moreover, most hunger strikers are not mentally ill. A lack of food by no means impairs the human capacity to make rational judgements. Hunger strikers often experience hallucinations and mental distress, but rarely go insane. This complicates matters. According to accepted medical ethics, sane patients have a basic right to be able to refuse medical treatment (including forcefeeding) if they wish. Moreover, force-fed prisoners typically insist that the procedure is used primarily to punish, degrade, and harm. They claim that the passing of a stomach tube through the inner body is intensely painful, as well as emotionally traumatic. Force-feeding has also been known to kill when liquid food has accidentally been decanted into the lungs rather than stomach, the end result being a rapid death from pneumonia. Forcefeeding emerges from the historical and present-day record as physically dangerous, ethically precarious, and irrefutably unpleasant.

This study examines force-feeding from historical perspectives. It unearths prisoner experiences, public reactions, and ethical debates. It situates force-feeding within broader ideas on pain and suffering, recaptures the emotional and physical sensation of being fed, and assesses the contrasting meanings attached to force-feeding in the various socio-political contexts in which it was performed. The main focus is on England, Ireland, and Northern Ireland, a complex geo-political region in which heated debates on force-feeding first emerged and recurrently resurfaced throughout much of the twentieth century. Although Russian prisoners went on hunger strike in the nineteenth century, ${ }^{7}$ it was English suffragettes who first demonstrated the political potency of hunger striking in groups. ${ }^{8}$ Between 1909 and 1914, imprisoned suffragettes refused food collectively and exhibited an absolute determination to fast until death, if necessary. To avoid a martyrdom, the Home Office authorised forcefeeding. Incensed suffragettes and an array of unpartisan critics posed a number of challenging ethical questions. Is force-feeding safe? Can it kill? Are doctors who force-feed acting ethically, in line with the norms of their profession? Or, instead, have they become pawns in a battle of wills between government and prisoners? And do these doctors really believe that they are saving lives? Or are they perhaps more interested in disciplining recalcitrant prisoners?

When suffragettes stopped hunger striking in 1914, these questions remained unresolved. Undeterred by hostile public opinion, and perhaps 
impressed by the efficacy of feeding technologies in quelling prison rebellion, the British government maintained its policy of feeding hunger strikers. Just as the suffragette campaign quietened during wartime, the Irish republican movement began to gain considerable momentum. Irish national independence was ultimately secured in 1921. As had been the case when dealing with the suffragettes, the British government used imprisonment extensively to tackle republican dissidence. Inspired by the suffragettes, a large number of republicans went on hunger strike, only to be fed against their will. The contentious death of prominent Irish Republican Army (IRA) member, Thomas Ashe, in 1917 ultimately forced a change in hunger strike management policy in Ireland. ${ }^{9}$ Ashe was the first political casualty of force-feeding; pneumonia infected his body following a botched feeding attempt by an inexperienced doctor. But even despite this prominent fatality, prisoners outside of Ireland continued to be fed against their will. In England, conscientious objectors were force-fed throughout the First World War, often in a brutal, degrading way, despite firm evidence that the procedure could kill.

After 1917, England and Ireland had contrasting hunger strike management policies. In Ireland, republican prisoners continued to hunger strike throughout the War of Independence (1919-21) and Civil War (1922-23). In the latter conflicts, approximately 8000 republican prisoners staged hunger strikes. ${ }^{10}$ However, Irish prison doctors were reluctant to force-feed and grappled instead with the uneasy task of caring for patients as they slowly, and deliberately, wasted away. Most notoriously, the former Lord Mayor of Cork, Terence MacSwiney, died in 1920 after enduring seventy-four days without food, causing an international uproar. ${ }^{11}$ After securing national independence, the Irish government never authorised force-feeding. In contrast, force-feeding remained common in English prisons throughout much of the century. Numerous convict prisonersincluding murderers, anarchists, and peace protestors-went on hunger strike only to be subjected to the stomach tube. The commonplace nature of both hunger striking and force-feeding in twentieth-century English prisons passed mostly unnoticed until 1973 when four Provisional Irish Republican Army (PIRA) prisoners, including two young sisters Marion and Dolours Price, decided to refuse food. Their feedings attracted international attention. The death of PIRA prisoner, Michael Gaughan, in the following year following complications with force-feeding finally encouraged the Home Office to change its policies. Partly in response to the British government's mishandling of its politicised prisoners, the 
World Medical Association formally declared force-feeding as unethical in $1975 .{ }^{12}$ For the first time, the medical profession clearly outlined ethical standards on hunger strike management, even though force-feeding had by then proven controversial for nearly sixty years. Prisoners could no longer be fed against their will, one consequence being that ten PIRA members starved to death in Maze Prison, Northern Ireland, in 1981. These included Bobby Sands. Evidently, hunger striking was an important feature of the medical and emotional landscapes of the twentieth-century prison. A complex interplay evolved historically between two contrasting options: force-feeding and allowing self-starvation. Prisoners who went on hunger strike endured deep physical and emotional suffering. Those who were force-fed found themselves subject to pain, degradation, and, in many instances, physical and verbal intimidation. In turn, force-feeding called into question basic tenets that underscored medical ethics and modern understandings of liberal western society itself. The wilful infliction of pain clashed profoundly with expectations of medical professionalism and civilised behaviour.

\section{Historiography}

Why is a historical study of force-feeding important? Such an investigation fills a significant historiographical lacuna. When studying broader political campaigns such as republicanism, historians of Ireland have routinely denounced force-feeding as unsavoury and vicious. Their discussion has been condemnatory but rarely reflective. In his study of Irish imprisonment between 1912 and 1921, William Murphy briefly alludes to the ethical problems posed by force-feeding. ${ }^{13}$ Popular accounts of Irish hunger striking, such as Barry Flynn's Pawns in the Game, condemn the procedure as brutal and torturous. ${ }^{14}$ Yet the ethical issues that surround forcefeeding are far more intricate than these passing mentions suggest and warrant a more focused inquiry. Such a study would also shed light on the ethical, physical, and emotional aspects of hunger striking yet to come to light due to a tendency among historians of Ireland to focus almost exclusively on the political dimensions of twentieth-century prison protests. ${ }^{15}$ Recent oral history research into the Northern Irish Troubles undertaken by Greta Jones, James McKenna, and Farhat Manzoor has opened up possibilities for examining fresh aspects of Irish conflict. In their Candles in the Dark: Medical Ethical Issues in Northern Ireland during the Troubles, the authors highlight the complexity of providing and receiving medi- 
cal care in a conflict zone and the day-to-day challenges in adhering to medical ethical norms. ${ }^{16}$ In their study, the authors firmly demonstrate that hunger striking is a form of protest with implications that extend far beyond the political. For those who willingly starve themselves, food refusal bears physical, psychological, and emotional consequences.

Suffragette historians have proven more attentive to the medical and socio-cultural aspects of force-feeding. The technologies used to feed suffragette prisoners, and their emergence in Victorian asylums, have been illuminated by Elizabeth Williams and Sarah Chaney. ${ }^{17}$ Elsewhere, I have situated debates on force-feeding within a broader context of criticism directed at the Edwardian medical profession as supporters of violence against both animals and women and also investigated the medical ethical debates that emerged during the British suffragette campaign ${ }^{18}$ Feminist historian, Jennian F. Geddes, has rebuked the Edwardian medical profession for failing to speak out against force-feeding and supporting state policies. ${ }^{19}$ These studies highlight the ethical conundrum presented by force-feeding. Yet considerable scope exists for examining the endurance of force-feeding policies beyond the suffragette hunger strike campaign. Force-feeding remained in use in English prisons throughout much of the century. But historians have yet to critically evaluate the ruthless feedings of First World War conscientious objectors, unearth the harrowing experiences of convict prisoners subjected to the stomach tube, or examine the public uproar caused in the mid-1970s by the force-feeding of PIRA prisoners.

The issue of force-feeding taps into far broader historiographical themes including the history of medical ethics, gender, liberal political culture, Anglo-Irish relations, institutional welfare, prisoner well-being, radical movements, and social power. Historical analysis also has much to offer present-day debates. While it cannot hope to resolve the thorny ethical debates that currently surround the body of the twenty-first-century hunger striker, a historically grounded study could certainly help make sense of these controversies by offering historical insight and rooting discussions currently being waged by bioethicists, human rights activists, and politicians at the time of writing in a broader lineage of concern about force-fed prisoners. Although historically disparate, the presence of similar-almost identical-fundamental medical ethical concerns about force-feeding in historical and present-day incidences demonstrates some degree of continuity across time, as well as geographical space. Group hunger strikes tend to occur decades apart, meaning that medical communities often 
lack an immediate ethical framework based upon recent practice to refer to when the state initiates force-feeding policies. Today, the nearest focal point for western doctors is, perhaps, the hunger strikes staged during the Northern Irish Troubles. Yet the force-feedings that took place in that period have been mostly forgotten about outside of Northern Ireland. Concerned doctors are perhaps cognisant of the fact that suffragettes were once force-fed. Some (particularly in Ireland) may be familiar with the death of Thomas Ashe. Yet few would be conscious of the intricacy of the discussions recurrently played out throughout the twentieth century in the pages of Votes for Women, British Medical Journal and the Guardian, or in the tense atmosphere at the public inquest on Thomas Ashe's body in Dublin, 1917. Few would recognise the relevance of historical debates to current ethical discussion. Given the temporal distance of large-scale prison hunger strikes, historiographical analysis of past experiences and debates holds the potential to inform current approaches to hunger strike management and help make sense of a persistent ethical conundrum.

\section{Why Hunger STRIKe?}

In 1975, the World Medical Association formally declared force-feeding as unethical. Why, then, is the procedure still being used? Force-feeding has been resorted to once again in the context of an alarmist concern over 'terror' and the wilful refusal of the Bush and Obama administrations to adhere to international human rights practices. It has helped to tarnish twenty-first American policies. On 11 September 2001, Islamic fundamentalists destroyed the World Trade Center, New York, in an unprecedented display of 'terror'. Two months later, President George Bush authorised the indefinite detention of anyone suspected of involvement in 'terrorist' activity against America. The first group of detainees was transported to Guantánamo from Afghanistan in January 2002. Upon their arrival, Secretary of Defense, Donald Rumsfeld, announced that members of this group were to be held as 'unlawful combatants', not as prisonersof-war. He defended this loss of entitlement to special status on the basis that $\mathrm{Al}$-Queda was not a recognised state party, meaning that its members were exempt from the Geneva Convention, a series of treaties on the treatment of civilians and prisoners-of-war. Al-Queda, Rumsfeld insisted, was an international terrorist group. ${ }^{20}$

In the tense years that followed, experts heavily debated the legal status of Guantánamo, a site in which individuals could be housed indefi- 
nitely without trial. Critics denounced Guantánamo as a 'legal black hole'. ${ }^{21}$ The site seemed exempt from normal rules of law and warfare as well as standard judicial processes. ${ }^{22}$ As Italian philosopher Giorgio Agamben suggested, the legal status of detainees was radically erased at Guantánamo, producing legally unnameable and unclassifiable beings. Ominously, Agamben compared this to the loss of Jewish identity in Nazi concentration camps. ${ }^{23}$ Providing a counter-argument, influential political thinkers such as Michael Ignatieff insisted that the removal of a certain degree of privacy and human rights was a 'lesser evil' than the 'greater evil' which would ensure should the 'terrorists' win. ${ }^{24}$ Yet many disagreed with him. ${ }^{25}$ Even Ignatieff himself eventually tempered his arguments. During his election campaign, Barack Obama opposed the Bush's administration's handling of Guantánamo, although he made few changes to the camp upon coming to power in $2008 .^{26}$

Since 2002, detainees at Guantánamo have protested by hunger striking. ${ }^{27}$ In doing so, they have drawn international attention to their treatment and detention without trial. The camp's first hunger strike started in January 2002 and peaked at 150 detainees. It ended in the following month when officials apologised for mistreating the Quran. A more sustained period of hunger striking began in 2005 when detainees decided to protest their innocence and rally against their institutional treatment by refusing food. Hunger strikes took place intermittently at Guantánamo until 2013, when the aforementioned mass hunger strike commenced. In December 2013, the US military announced that it would no longer disclose information about hunger strikes. Force-feeding is known to have taken place since 2002. ${ }^{28}$

Does the nature of these protests share any commonalities with historical hunger strikes? In many ways, yes. Part of the detainees' anger stems from having been classified as 'enemy combatants' rather than prisoners-of-war. Historically, classification was a common motivation for hunger striking. In the 1910s, the Home Office refused to grant suffragettes political prisoner status, rousing numerous women to go on hunger strike. Similarly, Irish republicans often fasted (in the 1910s, 1920s, and $1970 / 80$ s) in protest against the British government's obstinate refusal to recognise their special status within the prison, to distinguish them from everyday criminals and thieves. Many politicised prisoners viewed having to associate with ordinary criminals as defilement and sought to secure space from the polluting influences of rapists, murderers, and thieves. According to their line of argument, politicised prisoners are different 
from ordinary criminals and should be treated as so. ${ }^{29}$ Yet special category status also held symbolic value. It might have confirmed that dissidents have valid political perspectives. This was ideologically problematic. How could female suffragettes have been awarded political prisoner status in a country that actively denied women political participation? Were individuals who expressed their political views by planting bombs and murdering civilians really deserving of special category status? And would such an acknowledgement have in some way validated political violence?

Evidently, hunger strikes are very much concerned with identity. By criminalising political offences, politicians actively undermined the political agendas of suffragettes and Irish republicans by casting their offences as terrorism or simple crime. A similar line of thought pervades government approaches to Guantánamo today. But this begs the question: What precisely constitutes 'terrorism'? A century ago, many viewed the militant suffragettes as akin to 'terrorists'. Yet few, if anyone, would consider them in this light today. In the 1910s and 1920s, Irish public opinion was deeply divided on the extent of violence being perpetrated for the cause of national independence. Yet the IRA members who then helped to secure Irish independence are today valorised in Ireland as heroes who successfully overthrew centuries of British oppression. Precisely who becomes defined as 'terrorist', 'dissident', or 'criminal' depends heavily on historical and political context. ${ }^{30}$ Nonetheless, political discourses of 'terrorism' and 'criminality' undoubtedly shape prisoner experiences, define terms of imprisonment, and provide the starting point of many incidences of food refusal. They also help governments justify harsh bodily interventions such as force-feeding unlikely to be considered acceptable in 'normal' circumstances.

Hunger strikes, past and present, are equally concerned with bodily autonomy and institutional conditions. For philosophers such as Michel Foucault, the modern prison is a site in which power runs 'through' the body. ${ }^{31}$ Prior to the nineteenth century, criminals who had committed even relatively trivial crimes were liable to be hanged. The gallows provided a visible and potent public symbol in place to deter the living from pursuing crime. ${ }^{32}$ In contrast, imprisonment became more common from the early nineteenth century. Western prisons were systematically reformed, although this reorganisation took the form of solitude, silence, isolation, the control of personal time (as exemplified by rigidly prescribed meal times), and the introduction of physically and psychologically exhausting regimes such as the treadmill. In Foucault's model, the modern prison 
system became inherently disciplinary and punitive; all punishments were now firmly directed towards the body and mind. ${ }^{33}$ The casting of politicised prisoners as 'terrorists' or enemies of the established social order further encouraged harsh institutional treatment, particularly if prison staff viewed their prisoners as part of an enemy threat to the nation, if not western liberality itself. To worsen experiences even further, politicised prisoners were more likely to rebel while incarcerated, to see their imprisonment as unfair and unjust. Pain and force were far from incompatible with the disciplinary tendencies of the prison and were routinely directed at prisoners with unshakeable political views.

Conflict between prison staff and politicised prisoners is regularly played out on the level of the body. Accusations of physical and mental torture-or at least cruel, inhuman, and degrading treatment-have recently solidified the idea that Guantánamo constitutes a serious human rights threat. $^{34}$ If anything, Guantánamo is now a byword for injustice. Upon returning home, released detainees have reported regular beatings, rape threats, psychological intimidation, and the cutting of body parts including the genitals. ${ }^{35}$ Torture can be difficult to define. Psychological torture is immeasurably harder to gauge than physical torture as it tends not to leave an array of physical marks and bruising as evidence. ${ }^{36}$ However, it certainly exists. Sociologists have gone so far as to depict Guantánamo as the archetypical Foucauldian prison, an establishment where penal discourses, practices, and technologies are directed towards the bodies and mind of detainees. According to criminal rights expert Michael Welch, Guantánamo couples penal technologies with harsh interrogation, torture, repressive confinement conditions, and few prospects for release. Power relations act unfavourably on inmates who find themselves confined in a panoptican-like institution where they are constantly monitored by CCTV cameras and forced to sleep in brightly lit cells. ${ }^{37}$ The Pentagon's power over their bodies is absolute.

Suffragettes, conscientious objectors, and PIRA prisoners similarly complained of receiving exceptionally harsh institutional treatment due to their political views. Conditions for suffragette and Irish republican prisoners were perhaps not as imposing as they now are for Guantánamo detainees. However, many suffragettes (particularly those drawn from middle-class backgrounds) left the prisons horrified at the conditions which they had encountered, as did a considerable number of conscientious objectors during the First World War. Similarly, the widespread use of internment in Northern Ireland from 1971, followed by the con- 
struction of the formidable Maze Prison complex in which Bobby Sands died, raised concern about deplorable prison conditions and the manner by which the government chose to treat its incarcerated political opponents. The so-called 'dirty protest', in which Northern Irish republican prisoners smeared their own excrement over their cell walls and refused to wear anything other than a blanket, perhaps exemplifies the lengths politicised prisoners have gone to in order to rally against their institutional treatment.

How can autonomy be regained in such contexts? Fasting offers an important opportunity to reassert bodily control in an environment deliberately designed to curtail individual choice and decision-making. Food is central to prison life. It helps to structure time, conditions custodial life, and is symbolic of the prison experience. ${ }^{38}$ Refusing food directly challenges the normal disciplinary workings of prisons. It disrupts day-to-day schedules and represents a firm rejection by prisoners of the regimented power systems that structure institutional life and the harsh, discriminatory conditions which they often face. It also invokes the idea that a prisoner or detainee has a right to die if they wish, perhaps the ultimate, most extreme, assertion of control over one's own body. If prisons are concerned with controlling life at its most basic levels, then hunger striking (with its potential to rescue a prisoner from unfair judicial systems, political injustice, and institutional brutality through death) signifies a complete dismissal of the basic principles that undergird the modern prison. Hunger striking subverts the power relations that run 'through' the prisoner's body. It also self-consciously presents an open challenge to the government which oversees the prison network and uses it to tackle political dissidence.

Moreover, hunger strikes can be remarkably effective. In numerous historical circumstances, the decaying body of a hunger striker has transformed into an object of political currency, allowing dialogues to open up between prisoners, the public, and the state. As James Vernon suggests, hunger strikes proved their worth in the twentieth century as a means of articulating political critique in a number of contrasting scenarios (including England, Ireland, and India). ${ }^{39}$ Hunger striking itself is a form of political expression transmitted via the body. Given that prisoners can no longer express their political views through traditional means such as voting, publishing, or donating to public organisations, food refusal allows prisoners to articulate their concerns and perspectives. ${ }^{40}$ Hunger striking is a highly communicative act. ${ }^{41}$ As Bobby Sands' example once again dem- 
onstrates, it can force the public to rethink the meanings attached to terms such as 'terrorism' and how the state enacts violence upon the body within institutions. ${ }^{42}$

Nonetheless, governments are armed with their own weapon: the stomach tube. Force-feeding robs prisoners of a scarce opportunity to assert sovereignty over their own bodies. It provides a powerful example of how institutional power and authority can be inscribed onto the bodies of prisoners. Force-feeding is a remarkably intrusive procedure that requires considerable force. Most prisoners struggle against the prison doctor's efforts to secure access to the most innermost of body regions: the digestive system. To avoid impending pain, they might hit or attack the doctor and his/her attendants and struggle violently against the agony of a tube being forcefully inserted through their bodies. For such reasons, prisoners are often pinned down and restrained during the procedure, further adding to a sense of degradation, subjugation, and humiliation. Forcefeeding ultimately negates the prisoners' self-declared reclamation of their own bodies and strips them of their proclaimed right to die. In that sense, it bears a psychological function, discouraging protests by undermining the mental will to continue fasting. In Foucauldian terms, these prisoners become subject to sovereign power acting directly upon their bodies. Force-feeding at Guantánamo can certainly be considered as an expression of sovereign power, a political management of subjects whose lives need to be preserved. ${ }^{43}$ However, force-feeding is an imperfect solution. The most determined prisoners choose to withstand pain and discomfort due to a firm conviction in their moral cause. Such prisoners also attract significant levels of journalistic attention which helps to damage the government's reputation. Moreover, the procedure calls into question basic tenets of western liberal society relating to the acceptability of inflicting pain upon institutionalised groups already bereft of independence and autonomy.

\section{Experiencing Force-FeEding}

What does it feel like to be force-fed? And how does it feel to perform the procedure? The experiences of Lady Judith Todd provide some insight. Born in 1943, Judith was the daughter of Garfield Todd, the president of Rhodesia between 1953 and 1958. In the early 1960s, Judith became politically active and openly opposed the minority government of Ian Smith, leader of the predominantly white government that declared independence from the UK in 1965. Smith—-the personification of white Rhodesia—was 
widely criticised as an unrepentant racist whose policies caused the deaths of thousands of native Zimbabweans. In January 1972, twenty-nine-year-old Judith was arrested and dispatched to a jail in Marandellas, Zimbabwe. Her father, Garfield, was imprisoned elsewhere at the same time. While incarcerated, Judith briefly went on hunger strike to protest against her detention. She was force-fed. Judith's protest proved successful. Her feedings garnered international media attention, and both Judith and Garfield were released several weeks later, although they were expelled from the country. Judith decided to relocate to London where she continued to protest against Smith's government and, later, Robert Mugabe's regime. ${ }^{44}$

Judith had been placed in solitary confinement indefinitely without charge or trial. Like many detainees at Guantánamo, she went on hunger strike to rebel against her circumstances. News of Judith's plight spread internationally. In an hour-long interview on London Weekend Television, Smith casually stated that if Judith chose not to eat, 'it does not worry me a great deal'. When asked if he intended to authorise force-feeding, Smith commented that he was unaware of the hunger strike, that the matter was 'of little consequence', and that he did not receive daily reports. ${ }^{45}$ Yet under his disinterested facade, Smith was determined to break Judith's hunger strike. Embarrassingly, it coincided with Smith's efforts to placate a Peace Commission's concerns that his government was using emergency powers to muzzle political opposition.

During the first few days of her protest, prison staff left tempting food in Judith's room in an effort to break her will power. She steadfastly refused all meals. ${ }^{46}$ Visitors reported that Judith was tremulous and shaking. ${ }^{47}$ After nine days of refusing to eat, Judith was led from her prison cell to the doctor's office and asked to take a seat. She then found herself being forcefully held down while a nurse pushed a tube into her throat. Judith vomited the tube out eight or nine times. Adding to the sense of intimidation in the doctor's office, prison officials warned Judith that this process would continue as long as her fast lasted. Exhausted and shaking, Judith immediately gave up her protest against (what she later described as) 'the vindictive reaction of the Smith regime to those of us who reject the Anglo-Rhodesian settlement proposals'. When the prison authorities allowed Judith's mother to visit her, the distressed prisoner reportedly said 'you must go away and tell people I couldn't take it. I failed. I would have gone on with the hunger strike, but force-feeding I could not take'. ${ }^{48}$ Evidently, Judith's encounter with the stomach tube was marred by intimidation and physical force. Her protest was ultimately broken by 
force-feeding, a procedure which she felt physically and mentally unable to cope with. Force-feeding also broke Judith's emotional resolve to persevere with her fast. Prison discipline had been successfully enacted upon her body to restore institutional order. It seems clear from Judith's account that she experienced force-feeding as a violent assault upon her body and mind, accompanied by physical and verbal intimidation. Its main purpose seemed to be to bring her protest to a sudden end for political purposes and to normalise institutional power relations. It represented an enactment of sovereign power upon the inner body itself.

How did Judith's experiences equate to official claims about the nature and purpose of 'artificial feeding'? Since the British Home Office first declared that suffragette prisoners needed to be fed against their will in 1909, governments have adamantly insisted that 'artificial feeding' is humane and necessary to stop irrational prisoners from taking their own lives. ${ }^{49}$ The contention that 'artificial feeding' is preferable to allowing suicide was similarly evoked by the Home Office in 1974 in its justification for feeding PIRA hunger strikers against their will. ${ }^{50}$ The American government currently presents 'artificial feeding' as a modality of prisoner care, a procedure that prevents self-harm and saves the lives of unreasonable fasting prisoners. ${ }^{51}$ According to the government, 'artificial feeding' is safe, life-preserving, and in line with standard hospital feeding practices, even if it is somewhat uncomfortable. Governments are adept at refuting counter claims. Official reviews of force-feeding practices at Guantánamo have confirmed that force-feeding helpfully saves lives. ${ }^{52}$ In 2007, George Bush's Bioethics Council informed him that force-feeding amounts to torture. Bush ignored the Council's damning opinions. ${ }^{53}$ This was despite a broad international medical consensus on force-feeding being a procedure best avoided. ${ }^{54}$

The portrayal of force-feeding as a benevolent form of therapeutic care forms part of an effort to transform hunger strikes into a medical, rather than political, problem. Upon becoming hospitalised, hunger strikers are no longer dangerous 'enemy combatants' or 'terrorists' but 'recipients of care'. ${ }^{55}$ By invoking notions of care, hunger strikes are medicalised, diverting attention from the political roots of these protests. The portrayal of force-feeding as a medical procedure has consistently undermined complaints made by prisoners of the excruciating agony caused by having a long tube inserted into the innermost reaches of their body. Rather than simply being a form of therapy, force-feeding can easily be construed as a 
political technology of the body, at worst, a degrading, ruthless form of medical treatment used to discipline the bodies of fasting prisoners.

How do those called upon to force-feed perceive the procedure? The medicalisation of hunger striking brings a new actor into the fold: the prison doctor. According to traditional medical ethics, doctors have a duty to save lives and preserve health. Ideally, all medical workers are expected to adhere to the ethical norms of their profession, underpinned by the Hippocratic Oath. This includes treating patients decorously and never providing treatment against a patient's will. The problem is that forcefeeding is not simply a medical procedure, it is a political act. By chance of being employed in a prison during periods of political tension, many doctors have been faced with the uneasy task of deciding what to do with a patient who refuses to eat. If they chose to feed him/her, they found themselves open to accusations of taking part in a broader political programme of subjugating political dissent. It could have been that many prison doctors had little interest in the political tumults outside of the prison and saw their duty to save lives as more important than political exigencies. But it is equally plausible that some male prison doctors employed in the 1910s truly opposed female demands for suffrage and that those employed in the 1970s were horrified at the nature of PIRA violence being perpetrated across Britain, Ireland, and Northern Ireland. Could their perceptions of the 'terrorist' prisoner have informed their decision to pick up the stomach tube and, in some cases, use it to inflict pain and violence?

In theory, governments traditionally left decisions to feed to the discretion of prison doctors. Nonetheless, many doctors undoubtedly felt pressured by the government and their institutional superiors to force-feed, even if the procedure clashed with their ethical or personal inclinations. As Leith Passmore demonstrates in relation to post-war West Germany, the political pressure placed on prison doctors to perform force-feeding has been known to conflict with ethical inclinations and place considerable mental strain on doctors. One West German doctor who was persuaded to force-feed committed suicide. ${ }^{56}$ The role of prison doctors is inherently complex. They operate in a 'dual loyalty' to the ethical norms of their profession and the needs of the institution in which (s)he works. Part of the prison doctor's role inevitably involves helping to enforce institutional discipline. As historian Joe Sim argues, prison doctors historically took on a proactive role in enforcing discipline; they were crucial figures in the disciplining of the body. ${ }^{57}$ According to Sim, prison doctors have not simply benevolently healed prisoners at times of illness but also helped to 
actively enforce the apparatus of physical and psychological control that surrounds prisoners.

Scenarios of conflict often worsened this situation. Prison doctors dealing with politicised prisoners found themselves engaging with political agendas and performing acts that would be deemed unacceptable in peacetime. Certainly, this has been the case at Guantánamo recently. Since 2004, evidence has mounted of medical personnel failing to maintain medical records, conduct routine medical examinations, and take proper care of disabled and injured detainees. Critics have accused them of falsifying medical records and death certificates as well as sharing private medical information to help design coercive psychological interrogation techniques. ${ }^{58}$ An outraged international medical community has expressed vehemence about doctors co-operating in practices widely considered as torturous including sleep deprivation, prolonged isolation, feigned suffocations, and beatings. ${ }^{59}$ Guantánamo's medical staff tend to be depicted as pawns in a political game, as individuals who have abandoned the medical ethical norms of their profession by breaching fundamental human rights to support military objectives. ${ }^{60}$

If Guantánamo can be regarded as a site in which physicians play a pivotal role in enacting discipline, can force-feeding be construed as yet another manifestation of physical and mental torture? This is certainly the view of many medical ethicists and the detainees themselves. The claim that forcefeeding is tantamount to torture has pervaded critiques of the procedure since the suffragettes first objected to being fed in 1909. Suffragettes likened force-feeding to oral rape. ${ }^{61}$ They portrayed it as a vindictive act that did little to preserve health but certainly helped the government to subjugate, degrade, and brutalise its political opponents. Force-fed male prisoners were less inclined to call upon the allegory of oral rape, but similarly depicted their encounter with the stomach tube as needless and excruciatingly painful. Regardless of political or geographical context, representations consistently emerged of force-feeding as an unwarranted assault upon the body performed solely to enact discipline and dissipate political will. Prisoners in all of the historical contexts discussed in this monograph perceived the procedure as a punitive disciplinary mechanism.

Various arguments underpinned historical accusations of torture. The fact that prison doctors normally force-fed in the first week of a hunger strike seemed suggestive. Terence MacSwiney's hunger strike of 1920 firmly demonstrated that prisoners could potentially remain alive without eating for over seventy days. In relation to Judith Todd, The Guardian 
commented in 1972 that there seemed to have been no reason to force-feed her. Quoting an anonymous English doctor, the newspaper stated that 'they obviously hate her guts, quite literally. There is absolutely no need to forcibly-feed a young, healthy adult - no one's going to die after an eightday fast. That's nonsense. To call it "treatment" is medically very cynical'. The commencement of force-feeding early on in a hunger strike, especially when accompanied by verbal and physical intimidation, allowed critics to portray the procedure as brutal and unnecessary. In 1972, the Guardian asserted that force-feeding could only be 'properly described as torture' and asked: 'Is this necessary treatment, with a prisoner's health in mind, or is it closer to punishment, with a prisoner's subjugation in mind?'. The editorial continued by lamenting:

However humane a future physical solution may be, the practice of forciblefeeding is and will always be an assault against the rights of another human being over his own body. After all, to kill yourself outside prison walls is no crime. Unfortunately it is, quite simply, easier to force a tube into someone's stomach than listen to them and see if their demands can be met. ${ }^{62}$

In addition, it hardly seemed to be in the public interest for prison doctors to tackle hunger striking with their stomach tubes. Prison hunger striking caused no harm to other prisoners or staff members, or to the general public. It was an inwardly directed form of violence that harmed only the protestor him/herself. Nor could hunger striking truly be classified as suicide. The intention of refusing food was to draw attention to political or institutional concerns. Hunger strikers did not usually set out with the intention of ending their own lives, although they recognised this as a possibility. ${ }^{63}$ Instead, swiftly curtailing a hunger strike with a stomach tube seemed to be a 'lesser evil' than permitting self-starvation, even if it did entail an impermissible intrusion into personal autonomy. ${ }^{64}$ The forceful ending of a hunger strike also quelled journalistic interest. In comparison, protracted periods of self-starvation have tended to attract prolonged media coverage, as evidenced by the international attention garnered by the Maze Prison hunger strikes of 1980-81.

To further buttress claims of torture and medical excesses, force-feeding has often been performed painfully, violently, and with force and restraint. In the twentieth century, most force-fed prisoners complained of receiving unfair prison treatment more generally. They claimed that their prison experiences were marred by violence and excessive punishment. Given this 
broader context, force-feeding has always become entangled with broader debates on human rights, civil liberties, torture, and the function of statesupported violence in modern liberal societies. Privacy, self-determination, and bodily integrity are now fundamental human liberties in western cultures, even in prisons. Yet the state also has an interest in preserving life and maintaining order in institutions which strongly mitigated against the privacy rights of prisoners such as Judith Todd. In the historical examples outlined in this study, the state's interest in tackling political dissidence in prisons mostly outweighed prisoner rights. This study explores the multifaceted experiences of both being force-fed and performing force-feeding. To achieve this, it uses a wide range of sources including oral history testimonies, autobiographies, prison diaries, propaganda, letters, newspaper accounts, and official documentation to recapture the physical and emotional intricacies historically embodied in the act of force-feeding.

\section{Public Protests}

If force-feeding is entangled with far broader debates about medical ethics, human rights, prisoner welfare, and western liberality, then it is unsurprising that the issue has captured public attention since the inception of force-feeding policies in 1909. It garnered interest even from those who had no sympathy whatsoever for political violence or particular causes. Forcefeeding prompted debate as it conflicted with modern western sensitivities towards pain, humanity, and individual rights. By the early twentieth century, freedom from physical coercion and deliberately inflicted pain was generally seen as a basic human right. In an increasingly secular society, suffering served little symbolic value while citizens were encouraged to demonstrate compassion towards those subjected to interpersonal violence and abuse. Anecdotes of institutional brutality provided reference points for a broader debate on the rights of dependent persons held in state-managed institutions. ${ }^{65}$ Critics encouraged the public to imagine what it felt like to be forcefed, to empathise with those depicted as being in physical and mental agony. It was this imagining of painful encounters that propelled passionate public responses. In the west, the wilful infliction of pain is an act supposedly banished to the past; hanging, lashing, and torture are today seen as barbaric practices that fell out of fashion during the transition from pre-modern to modern society. ${ }^{66}$ Imposing discomfort on criminals seems somewhat superfluous. Exclusion from society is supposed to be punishment enough; there appears to be no need to inflict further distress in prisons. Indeed, in the post 
9/11 world, western commentators typically depict the Muslim East as a space of torturous institutional practices, somewhat ironically. ${ }^{67}$ It is in 'less civilised' countries (such as the Islamic state and often Russia) that outdated prison conditions are meant to prevail, not in the 'civilised' west. ${ }^{68}$ Pain occupies a precarious position in the emotional economies of western societies.

The fact that doctors inflicted pain added further emotional contours to the matter. Over the past century, the western medical profession has built strict ethical standards designed to protect vulnerable patients, including the institutionalised. Largely in response to twentieth-century controversies, including Nazi experimentation and institutional child experimentation, the discipline of bioethics evolved internationally during the 1970s and 1980s to codify ethical practice and safeguard patients from the less savoury aspects of modern orthodox medicine. ${ }^{69}$ The framing of prison doctors as torturers, in both the past and present, raised broader questions about the role of medical professionals, particularly those working in politically charged circumstances. Force-feeding cast negative light on prison medicine. Perhaps unsurprisingly, force-fed prisoners have often received the most vocal support from members of the medical profession.

Inevitably, a large number of people have always existed who hold no sympathy whatsoever for the plight of force-fed 'terrorists'. The extremities of violence perpetrated by political dissidents often mitigated against compassion. Nonetheless, the broader socio-cultural issues at stake in force-feeding debates always ensured that sizable opposition surfaced when the procedure was being used. At the time of writing, international opposition is pronounced. Although World Medical Association guidelines weigh against force-feeding, individual governments are not legally obliged to adhere to these. Critics of the Association's universal rule suggest that it pays inadequate attention to regional and individual circumstances. Hunger strikes, some maintain, occur in a range of complex politicised contexts, a point which international ethical guidelines fail to fully consider. ${ }^{70}$ Declarations on force-feeding are not legally binding, meaning that the legal status of the practice remains blurry.

These arguments have failed to satisfy those concerned with prisoner welfare and an apparent misuse of medical power. The 2013 hunger strikes also encouraged Amnesty International to write to the Secretary of Defense, Charles Hagel, expressing concern about the well-being of Guantánamo detainees and reinforcing its long-held stance that forcefeeding is cruel, inhuman, and degrading. ${ }^{71}$ Yasin Bey, an actor and rapper previously known as Mos Def, featured in a well-publicised video that 
showed him being force-fed. Produced for human rights group Reprieve, the video displayed Bey's intense physical suffering as over a metre of rubber tubing was passed through his inner body. Bey, in tears, begged the physician to stop. ${ }^{72}$ These protests played upon public sensitivities to physical agony and emotional distress. In 2006, Birmingham-based neurologist and human rights activist, David Nicholl, wrote a letter to the Lancet, signed by 262 other doctors, in which he remonstrated against the feeding and restraint of Guantánamo detainees on the basis that it contradicted the Declarations of Tokyo and Malta. Nicholl pointed out that since 1974 British governments had respected the rights of prisoners to refuse medical treatment if they wished under very difficult circumstances, even allowing Northern Irish prisoners to die in $1981 . .^{73}$ In 2013, Nicholl commenced a five-day fast on the twelfth anniversary of the destruction of the World Trade Center. He sought to draw attention to the plight of Shaker Aamer who had been held at Guantánamo for eleven years without being charged. David started his hunger strike at the precise time that the first plane had hit the Twin Towers on 9/11. Shaker Aamer is known to have been part of the 2013 hunger strikes; he was repeatedly force-fed. ${ }^{74}$

In the same year, the American Medical Association wrote a twentyfive-page letter to Hagel condemning force-feeding as degrading and dangerous. ${ }^{75}$ The British Medical Association denounced force-feeding as a 'stain on medical ethics'. ${ }^{76}$ American physicians George Annas, Sondra S. Crosby, and Leonard H. Glantz remonstrated in the New England Journal of Medicine that military physicians should adhere to the same standards of practice as civilian physicians, even if they do work in unusual conditions. Hunger strikes, the authors asserted, are not a medical problem and should never be treated as one. ${ }^{77}$ In November, a task force composed of bioethicists and medical practitioners published a report entitled Ethics Abandoned: Medical Professionalism and Detainee Abuse in the War on Terror. The authors claimed that medical staff were participating in systematic torture and firmly dismissed suggestions that force-feeding was only being used when the life of a detainee was endangered. They also insisted that force-feeding contradicted US Bureau of Prisons policies which had strict rules on how physical restraint could be used and frowned upon the Department of Defense's practice of screening physicians before sending them to Guantánamo to ensure that they are willing to force-feed. The report concluded that force-feeding amounts to torture as it seemed inhumane and degrading. ${ }^{78}$ Torture itself is enough to arouse public anxiety. Yet the idea of pain being wilfully imposed by members of a trusted 
profession raises broader concerns about the nature of medical power and the use of therapeutic technologies for purposes other than to heal.

This study pays close attention to individuals who publicly objected to force-feeding. Intriguingly, many of those who remonstrated against the procedure in the twentieth century had no contact with the prisoners whom they set out to protect. Many had no obvious sympathy with the political agendas of the force-fed. Most abhorred the levels of political violence that was deeply affecting their communities. Nonetheless, they decided to condemn force-feeding due to the powerful meanings attached to the act in modern western liberal culture. In the contexts discussed in this study, groups of medical men organised to investigate suffragette force-feedings; playwrights such as George Bernard Shaw publicly involved themselves in the issue; liberal newspapers including the Guardian rallied against force-feeding; Irish republicans used Thomas Ashe's death to support its propaganda against British rule; peace movements debated the brutal feedings of its members; partisan campaigners with no knowledge of the political intricacies of Northern Ireland took to the streets to protest against PIRA force-feedings; both Northern Irish loyalists and republicans united to object to the feedings of the Price sisters. Force-feeding has always provoked mixed emotions among the public and has proven deeply objectionable to a diverse array of partisan and non-partisan critics.

\section{STRUCTURE}

This study is not intended as an exploration in political history, although the political contexts in which prison doctors force-fed form a backdrop. The main emphasis is on the construction of hunger striking as a medical problem and the institutional and social relations that emerged from this. The focus is on bodies, emotions, and the enactment of institutional and clinical power on a physical and psychological level. Most importantly, it investigates ethics. Since 1909, broadly similar ethical questions have surfaced about force-feeding in contrasting contexts. Yet force-feeding carried particular meanings in different socio-political and geographical climates. The same basic ethical questions remained the same but were negotiated in light of considerations including gender, nationality, and attitudes towards political dissidence. The force-fed body has always been portrayed as a helpless victim of medical torture. Yet stomach tubes were inserted into different types of bodies throughout the twentieth century: 
male and female bodies, British and Irish bodies, politicised and convict bodies, wartime and peacetime bodies.

The omnipresent similarity of debate means that historical analysis of force-feeding can be used to shed light on recurrent ethical problems. In adopting an approach that aims to speak to present-day concerns, this study draws upon the ideas of historians including Sarah Ferber and Duncan Wilson who have called for a greater integration of historical analysis and bioethical research. In Bioethics in Historical Perspective, Ferber suggests that history can be thought about in relation to medical ethics in meaningful ways. Knowledge of ideas and events which still bear on the conduct of medicine could be used to contribute to medical policy and practice. Historical reflection on medical ethics, Ferber maintains, can help to find answers to immediate policy issues while also examining how questions about medical practice and policy were posed in the first place. ${ }^{79}$ It is unlikely that history will always provide firm answers, but it could encourage bioethicists to ask the right questions in the first place by demonstrating how moral positions are rooted in specific socio-cultural and historical contexts. ${ }^{80}$ Strengthening this line of thought, Wilson points out that historians of medicine are conspicuously absent from the interdisciplinary field of bioethics (which is comprised of professionals including doctors, sociologists, and ethicists). Wilson argues that historians need to overcome their long-standing scepticism towards bioethics and view it instead as an interdisciplinary meeting-ground where historical perspectives could productively contribute. The history of medical ethics, Wilson maintains, does not necessarily have to involve radically critiquing dubious aspects of medical history. ${ }^{81}$

This study by no means seeks to add to the sensationalistic trend of writing shocking exposés of the medical past. Accordingly, it refrains from depicting prison doctors simply as brutal torturers intent on shoving stomach tubes deep into the bodies of defenceless suffragettes and Irish republicans. Instead, it offers a more nuanced, reflective, account of prison medical practice and prisoner experiences. For instance, it examines how prison doctors navigated the ethical problems that surrounded forcefeeding; the ways in which the bodies of hunger strikers were monitored, regulated, and cared for; and the diversity of opinion (even within the medical profession) on the need to feed prisoners against their will.

Each chapter focuses on a particular aspect of force-feeding. Combined, the chapters provide a broadly chronological account of force-feeding as it took place across the British Isles. Chapter 2 asks: How and why did 
ethical debates on force-feeding first develop and evolve? What were the main issues at stake? And why did some members of the medical profession find force-feeding so problematic? Between 1909 and 1914, militant suffragettes staged the first group hunger strikes, placing the Home Office and prison doctors in a precarious position. Should these women be released, fed, or allowed to starve? Force-feeding was decided upon. The government presented 'artificial feeding' (as used in asylum care) as a life-saving medical intervention being used to stop irrational women committing suicide. In sharp contrast, released prisoners complained of relentless vomiting, rough treatment at the hands of prison doctors, and physical trauma. Evidently, two opposing interpretations of force-feeding immediately came into play.

The chapter examines how the key ethical questions that still surround force-feeding first formed during the suffragette hunger strike campaign. Contemporary critics denounced force-feeding as torturous, dangerous, coercive, and as a perversion of normal medical ethics. The chapter also pays attention to the troubled role of the prison doctors who force-fed and who, for the first time, became cast as torturers. It suggests that outraged suffragettes were adept at eliciting support from the English medical community who willingly provided damning evidence on the problematic nature of force-feeding and claimed that prison doctors who fed were 'prostituting' their profession to help the government defeat political opposition. Medical ethics, it seemed, had been temporarily abandoned in English prisons. This chapter also examines other questions posed in this period. Is force-feeding psychologically and emotionally damaging? And is it acceptable to feed mentally ill and physically disabled prisoners against their will? Overall, this chapter introduces the core ethical questions that have been asked about the paternalism of force-feeding, setting the stage for a more detailed consideration of specific aspects of these debates in subsequent chapters.

Chapter 3 investigates the fraught career trajectories of doctors employed in prisons at times of political crisis. It focuses on the problem of medical participation in force-feeding and the dubious role of prison doctors who have helped state bodies tackle political dissidence. As a case study, the chapter focuses on one doctor employed at Mountjoy Prison, Dublin, throughout the Irish revolutionary period: Raymond Granville Dowdall. By chance of being employed in a prison during a period of political tumult, Dowdall encountered an array of politicised prisoners, including suffragettes, labour leaders, and Irish republicans. Dowdall force-fed many of them when they 
went on hunger strike. In doing so, he found himself positioned precariously between the state and the fasting prisoners under his care. This chapter also suggests that institutional problems develop when medical staff harbour negative attitudes towards politicised prisoners. Doctors do not always act neutrally; they share attitudes towards certain patients which can affect treatment, particularly during conflict when the willingness of doctors to adhere to medical ethical norms can be compromised by the socio-political climate in which they reside. This problem manifested in the brutal treatment of imprisoned Irish republicans following the Easter Rising of 1916. Republican prisoners were awarded worryingly low levels of therapeutic care and subjected to harsh punishments. When prominent Irish Republican Brotherhood (IRB) member, Thomas Ashe, died in 1917 after being forced to sleep without bedding on the floor of a cold cell for a number of nights, and then being force-fed, Dowdall became implicated as a 'puppet' of the British government, as an individual who had willingly murdered on behalf of the state. An emotionally charged inquest followed. Dowdall suffered a nervous breakdown and died in the following year. By using Dowdall as a case study, this chapter explores the attitudes of doctors towards prisoners whom they fed, the deeply problematic career trajectories of doctors who have worked in conflict zones, and the broader problems that have emerged when prison doctors become embroiled in the task of helping to maintain civil order.

Chapter 4 asks: What does it feel like to be on hunger strike? It makes extensive use of autobiographical evidence to recapture the physical and emotional experiences of fasting in revolutionary period Ireland. It provides a deeply personal account of the physical and emotional trauma entailed in starving oneself to death, encouraging reflection on the question of whether it is more ethical to let prisoners starve than to feed them. After Ashe's death, force-feeding was gradually abandoned in Ireland. New policies of permitting self-starvation were set in place although, in reality, most prisoners were prematurely released. The chapter probes into how the bodies and minds of hunger strikers slowly decayed in Irish prisons. It suggests that hunger strikers tended not to feel the effects of hunger until around ten days into a protest. During the first week, hunger subsided as the body consumed its internal fat supplies. Yet bodies rapidly lost weight and prisoners experienced hallucinations. It was only in the second week of a hunger strike that prisoners began to collapse and become bed-bound. Most were released after around fifteen days. Hunger strikers learnt instinctually that the human body requires a period of slow 
recuperation. If food was consumed too rapidly upon coming off hunger strike, serious injury-even death-could occur.

In addition, this chapter suggests that a series of prolonged hunger strikes in 1920 (which resulted in the deaths of three prisoners including Lord Mayor of Cork Terence MacSwiney) radically changed understandings of human starvation. Whereas suffragette prisoners had been force-fed in the first week of a hunger strike due to a fear that they would die in a matter of days, from 1920, it seemed clear that fasting prisoners could remain alive for some months, albeit in an incapacitated condition. It transpired that force-feeding had in fact been unnecessary in the first week of a hunger strike to save lives. This chapter also examines the changing functions of prison doctors whose role adjusted from force-feeding 'torturer' to helpless overseers of death. It argues that the abandonment of force-feeding in Ireland encouraged relatively compassionate relationships to form between doctors and their starving patients. Doctors struggled emotionally to care for patients who were gradually wasting away and whose health and lives could have been saved by the simple act of resuming eating. Overall, the chapter assesses the problems that emerge when doctors cannot force-feed, pointing to some reasons why certain doctors might consider feeding prisoners as ethically preferable to letting them starve to death.

Chapter 5 investigates how war has impacted on the experiences of hunger strikers. It suggests that broader contexts of international warfare have encouraged military and prison staff to treat politicised prisoners particularly harshly. During wars, politicised prisoners are often cast as enemies of the state, paving the way for institutional violence and inhumane treatment. War breeds hatred and contempt reflected in severe institutional treatment. In such circumstances, hunger striking is exceptionally common. Yet protests take place in the face of powerful discourses on the danger seemingly posed by political dissidents to the safety of the nation. As a case study, the chapter focuses on the plight of First World War conscientious objectors who were imprisoned due to their unwillingness to fight. They were beaten, subjected to verbal intimidation, and forced to live in deplorable conditions. When they went on hunger strike, prison doctors force-fed conscientious objectors in a brutal, degrading, and intimidating manner. Moreover, they fed prisoners despite a knowledge that force-feeding could kill if performed carelessly (as recently demonstrated by the death of Thomas Ashe). One conscientious objector died following a particularly violent bout of force-feeding. Somewhat paradoxically, 
this chapter suggests that wartime hunger strikers were often adept at drawing public attention to unacceptable institutional conditions. While imprisoned, they could do little to challenge the government that had incarcerated them. But opportunities arose to speak out once war ended. In the 1920s and 1930s, former conscientious objector prisoners successfully campaigned for prison reform. Some brought considerable change to the prison system. This chapter also briefly considers the fate of force-fed peace activists during the Cold War and Irish republican prisoners during the Second World War (or the 'Emergency', as it was termed in Ireland) who were allowed to starve to death. In summary, this chapter investigates the relationship between hunger strikers and wartime governments to consider how the discourses that surround conflict can tarnish the experiences of fasting prisoners.

Chapter 6 focuses on the question of whether force-feeding is therapeutic or punitive. Are hunger strikers really fed to keep them alive? Or do prison doctors recognise the punitive value of force-feeding in enforcing discipline, moulding behaviour, and maintaining prison order? It uses statistical and textual evidence relating to twentieth-century English convict prisoners who went on hunger strike to add support to the view that prison doctors performed the procedure to enact discipline and subdue rebellion. It makes extensive use of newspaper coverage and a unique source: a detailed register of hunger strikes staged in English prisons maintained by the Prison Commissioners of England and Wales. Between 1913 and 1940, the Commissioners meticulously recorded prisoner motivations for hunger striking, the length of hunger strikes, the different feeding methods used by doctors, and the prisons in which prisoners staged hunger strikes, leaving behind a detailed record of convict force-feeding.

The chapter maintains that force-feeding was remarkably common in twentieth-century English prisons. It suggests that force-feeding brought most convict hunger strikes to a swift end. Most prisoners were unable to withstand the physical and emotional agony of being fed against their will. However, a small (but highly vocal) number of prisoners did endure prolonged periods of hunger striking and force-feeding (sometimes up to two years) due to the firm conviction which they held in the moral right of their protest. Some sought to maintain their innocence. Others felt that they had been unfairly convicted on the basis of their beliefs, including anarchism and right-wing racism. They successfully resisted the disciplinary tendencies of prison doctors who sought to end their protests with their feeding tubes. In summary, the 
chapter provides evidence that prison doctors who fed fully recognised the disciplinary value of the stomach tube.

Chapter 7 asks: Why was it only in 1975 that the medical profession formally declared force-feeding as unethical? The feeding of hunger strikers had caused controversy for over sixty years. After all, suffragettes and Irish republicans had amassed considerable support for their anti-forcefeeding campaigns. Yet their protests had failed to translate into policy change. This chapter explores the force-feeding of PIRA prisoners in English prisons in the mid-1970s. It focuses on the feeding of two young Northern Irish sisters-Marion and Dolours Price-whose prison experiences garnered international attention. Upon being force-fed, their plight attracted sympathy even among those with little empathy for PIRA violence. This chapter argues that a particular socio-cultural climate existed in the 1970s that facilitated the formal condemnation of force-feeding by the medical profession. As in the past, force-feeding raised basic questions about the purpose of inflicting pain on politicised prisoners in a western, liberal culture that felt compassion for those perceived to be in physical distress. The emotional economies of post-war British culture clashed with the rational political logic of using force to maintain national security. Yet the climate in which force-feeding took place had radically changed by the 1970s. Higher public sensitivities towards medical paternalism and torture existed following the Nuremburg trials of the 1940s. This was linked to the development of a robust human rights movement and, more specifically, the evolution of concern over prisoner welfare. In the 1970s, PIRA prisoners found support from a broader international community of human rights and prisoner welfare activists who saw force-feeding as a severe breach of human dignity and basic rights. The high public profile of debates on PIRA force-feeding (in comparison to that experienced by convict prisoners) drew attention to broader concerns about English and Northern Irish prison conditions.

This chapter also links the abandonment of force-feeding policies in England to the emergence of modern bioethics. The post-war period witnessed mounting concern about the nature and misuse of medical power, as exemplified by contemporary debates on matters such as human experimentation. Prison medicine became targeted as an archetypical example of the excesses of institutional medical power. Medical staff were criticised for helping to maintain prison discipline rather than acting autonomously from the state. In 1974, the death of PIRA prisoner, Michael Gaughan, ultimately forced a reconsideration of the official stance on the safety 
of 'artificial feeding'. The Declaration of Tokyo (1975) outlined forcefeeding as unethical in light of this death, while also considering broader matters relating to medical professionals working in conflict zones who engaged in torture and political coercion. This chapter demonstrates that PIRA force-feedings were pivotal to the announcement of the Declaration and traces the evolution of medical discussion in England between Gaughan's death and the announcement of the Declaration. The chapter concludes by discussing the shifting roles of doctors during the Northern Irish Troubles who were now called upon to care for the starving bodies of hunger strikers without being able to intervene. Using oral history evidence, it suggests that this policy change placed considerable mental strain on doctors working in a conflict zone. Many were unable to cope with the pressure of letting patients die. One shot himself in the head. In summary, this chapter investigates the reasons why force-feeding came to be agreed upon as ethically unacceptable in the context of the Northern Irish Troubles, seemingly ending a debate that had first arisen in 1909 during the suffragette hunger strikes.

\section{Notes}

1. Chris Yuill, 'The Body as Weapon: Bobby Sands and the Republican Hunger Strikes', Sociological Research Online, 12:2 (March 2007). www. socresonline.org.uk/12/2/yuill.html. Accessed 2 March 2015, 12.18; Megan A. O'Branski, “The Savage Reduction of the Flesh': Violence, Gender and Bodily Weaponisation in the 1981 Irish Republican Hunger Strike Protest', Critical Studies on Terrorism, 7:1 (2014), pp. 97-111.

2. Patrick Hanafin, 'D(en)ying Narratives: Death, Identity and the Body Politic', Legal Studies, 20:3 (September 2000), pp. 393-408 on p. 393.

3. See, for instance, Barry Flynn, Pawns in the Game: Irish Hunger Strikes 1912-1981 (Cork: Collins Press, 2011), pp. 202-23.

4. Allen Feldman, Formations of Violence: The Narrative of the Body and Political Terror in Northern Ireland (Chicago: University of Chicago Press, 2008), pp. 234-5.

5. See Dominique Martine Grisard, 'The Spectacle of the Hunger-Stricken Body: A German-Italian Terrorist, Swiss Prisons and the (Ir)Rational Body Politic', European Review of History, 22:1 (2015), pp. 136-60.

6. 'Rethinking the Role of Tube Feeding in Patients with Advanced Dementia', New England Journal of Medicine, 342:3 (20 January 2000), pp. 206-10.

7. Vera Fichner, Memoirs of a Revolutionist (New York: Greenwood Press, 1968 [1927]). 
8. Kevin Grant, 'British Suffragettes and the Russian Method of Hunger Strike', Comparative Studies in Society and History, 53:1 (January 2011), pp. 113-43.

9. William Murphy, Political Imprisonment and the Irish 1912-1921 (Oxford: Oxford University Press, 2014), p. 33.

10. Michael Biggs, 'The Rationality of Self-Inflicted Sufferings: Hunger Strikes by Irish Republicans, 1916-23', Sociology Working Papers, 3 (2007), pp. 1-24.

11. Dave Hannigan, Terence MacSwiney: The Hunger Strike that Rocked an Empire (Dublin: O'Brien Press, 2010).

12. www.ma.net/en/30publications/10policies/cl8/index.html. Accessed 11 March 2013, 15.19.

13. Murphy, Political Imprisonment and the Irish, pp. 21-2.

14. Flynn, Pawns in the Game, pp. 18-38.

15. Book-length studies not cited above include David Beresford, Ten Men Dead: The Story of the 1981 Hunger Strike (London: HarperCollins, 1994 [1987]); Padraig O'Malley, Biting at the Grave: The Irish Hunger Strikes and the Politics of Despair (Belfast: Blackstaff Press, 1990); Danny Morrison, Hunger Strike: Reflections on the 1981 Republican Hunger Strike (London: Brandon, 2006); R. K. Walker, The Hunger Strikes (Belfast: Lagan Books, 2008); F. Stuart Ross, Smashing H-Block: The Popular Campaign Against Criminalisation and the Irish Hunger Strikes, 1976-1982 (Liverpool: Liverpool University Press, 2011); Thomas Hennessey, Hunger Strike: Margaret Thatcher's Battle with the IRA, 1980-1981 (Dublin: Irish Academic Press, 2013).

16. James McKenna, Farhat Manzoor and Greta Jones, Candles in the Dark: Medical Ethical Issues in Northern Ireland during the Troubles (London: Nuffield Trust, 2009).

17. Elizabeth A. Williams, 'Gags, Funnels and Tubes: Forced Feeding of the Insane and of Suffragettes', Endeavour, 32 (2008), pp. 134-40; Sarah Chaney, "Fat and Well': Force Feeding and Emotion in the NineteenthCentury Asylum'. emotionsblog.history.qmul.ac.uk/2012/06/fat-andwell-force-feeding-and-emotion-in-the-nineteenth-century-asylum. Accessed 24 April 2015, 14.38.

18. Ian Miller, 'Necessary Torture? Digestive Physiology, Vivisection, the Suffragette Movement and Responses to New Forms of Clinical Practice in Britain, c.1870-1920', Journal of the History of Medicine and Allied Sciences, 64:3 (July 2009), pp. 333-72; Ian Miller, A Modern History of the Stomach: Gastric Illness, Medicine and British Society, 1800-1950 (London: Pickering and Chatto, 2011), pp. 61-2 and pp. 72-9; Ian Miller, "A Prostitution of the Profession?': Forcible Feeding, Prison Doctors, Suffrage 
and Medical Ethics, 1909-14', Social History of Medicine, 26:2 (April 2013), pp. 225-45.

19. Jennian F. Geddes, 'Culpable Complicity: The Medical Profession and the Forcible Feeding of Suffragettes 1909-14', Women's History Review, 17 (2008), pp. 79-94.

20. Luisa Vierucci, 'Prisoners of War or Protected qua Unlawful Combatants? The Judicial Safeguards to which Guantánamo Bay Detainees Are Entitled', Journal of International Criminal Justice, 1:2 (August 2003), pp. 284-314.

21. George P. Fletcher, 'Black Hole in Guantánamo Bay', Journal of International Criminal Justice, 2:1 (March 2004), pp. 121-32.

22. Fleur Johns, 'Guantánamo Bay and the Annihilation of the Exception', European Journal of International Law, 16:4 (2005), pp. 613-35; Derek Gregory, 'The Black Flag: Guantánamo Bay and the Space of Exception', Geografiska Annaler, 88B:4 (December 2006), pp. 405-27.

23. Giorgio Agamben, States of Exception (Chicago: University of Chicago Press, 2005), pp. 3-4.

24. Michael Ignatieff, The Lesser Evil: Political Ethics in an Age of Terror (Edinburgh: Edinburgh University Press, 2005).

25. Derek O'Keefe, Michael Ignatieff: The Lesser Evil? (London and New York: Verso, 2011).

26. Tung Yin, “Anything but Bush?': The Obama Administration and Guantánamo Bay', Harvard Journal of Law and Public Policy, 34:2 (December 2010), pp. 453-92.

27. The Guantánamo Prisoner Hunger Strike and Protests February 2002-August 2005: A Special Report by the Center for Constitutional Rights (New York: Center for Constitutional Rights, 2005); Andy Worthington, Guantánamo's Hidden History: Shocking Statistics of Starvation (London: Cageprisoners, 2009).

28. http://america.aljazeera.com/articles/multimedia/guantanamohungerstriketimeline.html. Accessed 22 April 2015, 16.58.

29. Feldman, Formations of Violence, p. 156.

30. For definitions, see Randall Law, Terrorism: A History (Hoboken: Wiley, 2013), pp. 1-7.

31. Michel Foucault, Discipline and Punish: The Birth of the Prison (London: Penguin, 1977 [1975]).

32. Victor A. C. Gatrell, The Hanging Tree: Execution and the English People, 17701868 (Oxford: Oxford University Press, 1994). For Ireland, see Ian Miller, “No Hanging Here': The Persistence of the Death Penalty in TwentiethCentury Ireland', in Lisa-Marie Griffith and Ciaran Wallace (eds), Grave Matters: Death and Dying in Dublin (Dublin: Four Courts Press, 2016).

33. Foucault, Discipline and Punish. See also, Michael Ignatieff, A Just Measure of Pain: The Penitentiary in the Industrial Revolution, 1750-1850 (London: 
Macmillan, 1978); Patrick Carroll-Bourke, Colonial Discipline: The Making of the Irish Convict System (Dublin: Four Courts Press, 2000), pp. 21-60.

34. Richard J. Wilson, 'United State Detainees at Guantánamo Bay: The InterAmerican Commission on Human Rigs Respond to a 'Legal Black Hole", Human Rights Brief, 10:3 (March 2003), pp. 2-5; David Rose, Guantánamo: America's War on Human Rights (London: Faber and Faber, 2004); David Cole, Enemy Aliens: Double Standards and Constitutional Freedoms in the War on Terrorism (London and New York: The New Press, 2005).

35. Clive Stafford Smith, Bad Men: Guantánamo Bay and the Secret Prisons (London: Weidenfeld and Nicolson, 2007), pp. 49-80.

36. Metin Başoğlu, 'Torture vs Other Cruel, Inhuman and Degrading Treatment', Archives of General Psychiatry, 64 (March 2007), pp. 277-85 on p. 278.

37. Michael Welch, 'Guantánamo Bay as a Foucauldian Phenomenon: An Analysis of Penal Discourse, Technologies and Resistance', Prison Journal, 89:1 (March 2009), pp. 3-20 on p. 4.

38. Rebecca Godderis, 'Dining In: The Symbolic Power of Food in Prison', Howard Journal of Criminal Justice, 45:3 (July 2006), pp. 255-67. For Irish historical contexts, see Ian Miller, Reforming Food in Post-Famine Ireland: Medicine, Science and Improvement, 1845-1922 (Manchester: Manchester University Press, 2014), pp. 74-81.

39. James Vernon, Hunger: A Modern History (Cambridge, Mass. and London: Belknap Press, 2007), p. 60.

40. N. Y. Oguz and Steven H. Miles, 'The Physician and Prison Hunger Strikes: Reflecting on the Experience in Turkey', Journal of Medical Ethics, 31:3 (March 2005), pp. 169-72 on p. 170.

41. Lionel Wee, 'The Hunger Strike as a Communicative Act', Journal of Linguistic Anthropology, 17:1 (June 2007), pp. 61-76.

42. For broader discussion of hunger striking and shifting perceptions of 'terrorist' violence, see Patrick Anderson, 'To Lie Down to Death for Days: The Turkish Hunger Strike 2000-2003', Cultural Studies, 18:6 (November 2004), pp. 816-46.

43. Lauren Wilcox, 'Dying is not Permitted: Sovereignty, Biopower and Force Feeding at Guantánamo Bay', in Shampa Biswas and Zahi Zalloua (eds), Torture, Power, Democracy and the Human Body (Washington D. C.: University of Washington Press, 2011), pp. 101-28 on pp. 102-3.

44. Judith Todd, Through the Darkness: A Life in Zimbabwe (Cape Town: Zebra, 2007).

45. 'Mr Smith Indifferent if Miss Todd does not Eat', Times (14 February 1972), p. 6.

46. 'The Tempting of Judy: Smith Regime goes All-Out to End Her Jail Hunger Strike', Daily Mirror (14 February 1972), p. 4. 
47. 'Miss Todd goes on Jail Hunger Strike', Times (7 February 1972), p. 1.

48. 'Miss Todd's Hunger Strike Ended', Times (15 February 1972), p. 1.

49. See, for instance, the debate in 'Suffragettes in Prison (Supply of Food)', House of Commons Debates (6 October 1909), vol. 11 cols 1999-2002.

50. 'Prisoner (Artificial Feeding)', House of Commons Debates (30 January 1974), vol. 868 cols 441-5.

51. Corinna Howland, 'To Feed or Not to Feed: Violent State Care and the Contested Medicalization of Incarcerated Hunger Strikers in Britain, Turkey and Guantánamo Bay', New Zealand Sociology, 28:1 (2013), pp. 101-16 on p. 107.

52. Leonard S. Rubenstein, 'Medical Ethics at Guantánamo Bay Detention Centre and in the US Military: A Time for Reform', Lancet, 374 (25 July 2009), pp. 353-5.

53. Vladimir Bukovsky, 'Account of Torture', in Being Human: President's Council on Bioethics (Washington D. C.: President's Council, 2003), pp. 218-19.

54. Assistance in Hunger Strikes: A Manual for Physicians and Other Personnel Dealing with Hunger Strikers, trans. Paulien Cooper (Amersfoort: Johannes Wier Foundation, 1995).

55. Wilcox, 'Dying is not Permitted', p. 104.

56. Leith Passmore, 'The Ethics and Politics of Force Feeding Terror Suspects in West German Prisons', Social History of Medicine, 25:2 (May 2012), pp. 481-99.

57. Joe Sim, Medical Power in Prisons: The Prison Medical Service in England 1774-1989 (Milton Keynes and Philadelphia: Open University Press, 1990).

58. Peter A. Clark, 'Medical Ethics at Guantánamo Bay and Abu Ghraib: The Problem of Dual Loyalty', Journal of Law, Medicine and Ethics, 34:3 (Fall 2006), pp. 570-80.

59. 'Doctors and the War on Terrorism', British Medical Journal, 329 (10 July 2004), p. 66; Robert Jay Lifton, 'Doctors and Torture', New England Journal of Medicine, 351:5 (29 July 2004), pp. 415-16; M. Greg Bloche and Jonathan H. Marks, 'Doctors and Interrogators at Guantánamo Bay', New England Journal of Medicine, 353:1 (7 July 2005), pp. 6-8; Susan Okie, 'Glimpses of Guantánamo: Medical Ethics and the War on Terror', New England Journal of Medicine, 353:24 (15 December 2005), pp. 252934; Michael Wilks, 'Guantánamo: A Call for Action: Doctors and their Professional Bodies Can Do More Than You Think', British Medical Journal, 332 (11 March 2006), pp. 560-1; Steven H. Miles, 'Medical Ethics and the Interrogation of Guantánamo 063', American Journal of Bioethics, 7:4 (2007), pp. 5-11.

60. Jonathan H. Marks, 'Doctors as Pawns? Law and Medical Ethics at Guantánamo Bay', Seton Hall Law Review, 37:3 (2007), pp. 711-31. 
61. Miller, Modern History of the Stomach, p. 76.

62. Jill Tweedie, 'Editorial', Guardian (21 February 1972), p. 9.

63. See the debates in A Catholic Priest, The Ethics of Hunger Striking (London: Sands and Co., 1920), pp. 6-7. See also John Waters, 'The Morality of the Hunger Strike', Irish Ecclesiastical Record, 5:7 (August 1918), pp. 89-108; P. J. Gannon, 'The Ethical Aspect of the Hunger Strike', Studies: An Irish Quarterly Review, 9:35 (September 1920), pp. 448-54.

64. For debates on hunger striking and death, see Steven C. Sunshine, 'Should A Hunger Striker Be Allowed To Die?', Boston College Law Review, 25:2 (March 1984), pp. 423-58 on p. 458.

65. Elizabeth B. Clark, 'The Sacred Rights of the Weak: Pain, Sympathy and the Culture of Individual Rights in Antebellum America', Journal of American History, 82:2 (September 1995), pp. 463-93 on pp. 463-5.

66. Lynn Hunt, Inventing Human Rights: A History (New York and London: W. W. Norton and Company, 2007), pp. 70-112; Joanna Bourke, The Story of Pain: From Prayer to Painkillers (Oxford: Oxford University Press, 2014), pp. 231-69.

67. Shaista Patel, 'Racing Madness: The Terrorizing Madness of the Post-9/11 Terrorist Body', in Liat Ben-Moshe, Chris Chapman and Allison C. Carey (eds), Disability Incarcerated: Imprisonment and Disability in the United States and Canada (Basingstoke: Palgrave Macmillan, 2014), pp. 201-16.

68. Mikhail Khodorkovsky, My Fellow Prisoners (London: Penguin Books, 2014).

69. For broad analyses of the development of medical ethics, see David J. Rothman, Strangers at the Bedside: A History of how Law and Bioethics Transformed Medical Decision Making (New York: Basicbooks, 1991); Albert R. Jonsen, A Short History of Medical Ethics (Oxford and New York: Oxford University Press, 2000); Duncan Wilson, The Making of British Bioethics (Manchester: Manchester University Press, 2014). For case studies of medical ethical controversies, see, among others, Robert N. Proctor, Racial Hygiene: Medicine under the Nazis (Cambridge, M. A. and London: Harvard University Press, 1988); Francis R. Nicosia and Jonathan Huener (eds), Medicine and Medical Ethics in Nazi Germany (New York and Oxford: Berghan Books, 2002); Harriet A. Washington, Medical Apartheid: The Dark History of Medical Experimentation on Black Americans from Colonial Times to the Present (New York: Anchor Books, 2006); Allen M. Hornblum, Judith L. Newman and Gregory J. Dober, Against their Will: The Secret History of Medical Experimentation on Children in Cold War America (Basingstoke: Palgrave Macmillan, 2013).

70. Mary A. Kenny, Derrick M. Silove and Zachary Steel, 'Legal and Ethical Implications of Medically Enforced Feeding of Detained Asylum Seekers on Hunger Strike', Medical Journal of Australia, 180 (1 March 2004), pp. 237-40. 
71. www.amnestyusa.org/news/news-item/usa-authorities-must-endindefinite-detention-in-guantanamo-as-hunger-strike-grows. Accessed 31 March 2015, 15.07.

72. http://reprieve.org.uk/press/2013_07_08_guantanamo_force_feeding_ yasiin_bey. Accessed 25 March 2015, 12.21.

73. 'Force Feeding and Restraint of Guantánamo Bay Hunger Strikers', Lancet, 367 (11 March 2006), p. 811.

74. www.birminghammail.co.uk/news/local-news/birmingham-doctorhunger-strike-over-5910696. Accessed 24 April 2015, 13.06.

75. http://hrw.org/news/2013/05/13/joint-letter-chuck-hagel-forcefeeding-hunger-striking-prisoners-guantanamo-bay. Accessed 25 March $2015,12.34$.

76. Eleanor Crispin and Vivienne Nathanson, 'Force Feeding of Mentally Competent Detainees at Guantánamo Bay', British Medical Journal, 347 (12 July 2013), pp. 1-2.

77. George J. Annas, Sondra S. Crosby and Leonard H. Glantz, 'Guantánamo Bay: A Medical Ethics-Free Zone?’, New England Journal of Medicine, 369 (11 July 2013), pp. 101-3.

78. Ethics Abandoned: Medical Professionalism and Detainee Abuse in the War on Terror (New York, N. Y.: Institute on Medicine as a Profession, 2013), pp. xxi-xxvi.

79. Sarah Ferber, Bioethics in Historical Perspectives (Basingstoke: Palgrave Macmillan, 2013), pp. 2-10.

80. David Rothman, 'Behaviour Modification in Total Institutions', Hastings Center Report, 5:1 (February 1975), pp. 17-24 on p. 24.

81. Duncan Wilson, 'What can History do for Bioethics?', Bioethics, 27:4 (May 2013), pp. 215-23.

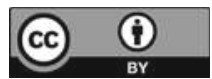

This chapter is distributed under the terms of the Creative Commons Attribution 4.0 International License (http://creativecommons.org/ licenses/by/4.0/), which permits use, duplication, adaptation, distribution and reproduction in any medium or format, as long as you give appropriate credit to the original author(s) and the source, provide a link to the Creative Commons license and indicate if changes were made.

The images or other third party material in this chapter are included in the work's Creative Commons license, unless indicated otherwise in the credit line; if such material is not included in the work's Creative Commons license and the respective action is not permitted by statutory regulation, users will need to obtain permission from the license holder to duplicate, adapt or reproduce the material. 


\section{'A Prostitution of the Profession'?: The Ethical Dilemma of Suffragette Force- Feeding, 1909-14}

In 2013, the British Medical Association wrote to President Obama and US Secretary of Defense Chuck Hagel inveighing against force-feeding policies at Guantánamo Bay. The Association was deeply concerned with the ethical problems associated with feeding prisoners against their will, seeing this as a severe violation of medical ethics. To support its emotive claims, the Association pointed to the Declarations of Tokyo (1975) and Malta (1991) which had both clearly condemned force-feeding as unethical. ${ }^{1}$ Nonetheless, American military authorities had resurrected the practice, the Association suggested, to avoid facing an embarrassing set of prison deaths that risked turning international opinion against Guantánamo and the nature of its management. ${ }^{2}$ Like other critics, the Association had some compassion for military doctors who seemed to be caught in an unhappy dilemma: Should they prevent suicides by force-feeding or oversee slow, excruciating deaths from starvation? Yet despite showing empathy, critics from within the medical profession, such as British general practitioner, Bernadette Gregory, generally concluded that 'doctors who participate in these practices [force-feeding] need to examine their own consciences'. ${ }^{3}$

Intriguingly, these sentiments echo those of suffragist sympathiser and physician Frank Moxon who, in 1914, asserted:

I consider that in a grave matter such as the forcible-feeding of sane and resisting prisoners, when one has strong reason to believe, despite ministerial statements to the contrary, that strong pressure is brought to bear on 
the prison doctors in order to induce them to carry out a procedure for the purpose of compelling prisoners to serve their sentences, that then it is not only permissible, but an obvious duty to protest against what I can only call a prostitution of the profession. It becomes all the more necessary to appeal to the general public when the leading officials of the medical profession are so blinded in their misplaced anxiety for the maintenance of the law, as to forget the real duties of their calling, as so well defined in the aforementioned Hippocratic Oath. ${ }^{4}$

Moxon published this powerful statement in his pamphlet What Forcible Feeding Means, distributed towards the end of five years of inconclusive debate about the ethical appropriateness of force-feeding suffragette prisoners. Throughout the thirty-six pages of his acerbic pamphlet, Moxon lambasted prison doctors for having abandoned the basic tenets of the Hippocratic Oath, lowering their standards of professional conduct, succumbing to government pressure to help defeat its political opposition, and performing a dangerous procedure on defenceless women. ${ }^{5}$ The similarities inherent in both of these renderings of force-feeding suggest considerable continuity over time. Both expressed astonishment that members of their own profession would wilfully partake in torture and brutality. Both voiced concern about the nature of the relationship between the state and prison doctors. And both sought to re-establish autonomy in medical decision-making to protect vulnerable patients. The persistence of these questions over almost a century suggests that the problems first posed by Moxon and others a century ago remain mostly unresolved.

The ethical quandary posed by prison force-feeding first became apparent during the suffragette hunger strikes of 1909-1914. This chapter traces the evolution of public opposition to the practice and demonstrates the effectiveness of suffragette appeals to medical ethics in eliciting professional support and challenging the government's insistence that 'artificial feeding' was safe. Suffragettes portrayed their force-fed bodies as being battered, assaulted, and harmed in an orgy of prison violence. In doing so, they evoked a crisis in professional conduct. They raised the spectres of medical torture, the politicisation of prison medicine, and an overruling of patient autonomy. In turn, force-feeding provoked an emotional public response rooted in sympathy for those seen as being in unbearable pain. The Home Office stood by its rational argument that prison doctors were simply saving the lives of irrational, suicidal women. Yet many felt horrified at the idea of defenceless women being tortured in penal institutions. The image 
of doctors wilfully inflicting pain on vulnerable female prisoners clashed with the emotional economies of modern, liberal Britain. Critics sought to negotiate the appropriate boundaries of bodily intervention and delineate the point at which medical practice mutated into torture. Somewhat perplexingly, historians have failed to fully examine the issues and ethical debates that surrounded suffragette force-feeding. June Purvis has commended members of the movement for showing courage and bravery when enduring force-feeding, which she denotes as torture. ${ }^{6}$ Similarly, Jennian F. Geddes has denounced force-feeding as 'an abuse', and one in which the British medical community was complicit for failing to formally condemn the practice. ${ }^{7}$ While both authors view force-feeding as an atrocity, neither fully considers the ethical intricacy of force-feeding debates. However, as I have noted elsewhere, the issues and questions raised in this short fiveyear period impacted significantly on public perceptions of prison medical practice. $^{8}$ A new penal technology - the stomach tube-had been introduced into English prisons and was to remain in place throughout much of the century. Understanding how these issues emerged paves the way for a more nuanced appreciation of the medical, ethical, and emotional aspects of hunger strike management in other historical and present-day contexts.

\section{From Asylums to Prisons}

Where did the idea of force-feeding come from? Fasting had not always been viewed as particularly problematic. Until the nineteenth century, the ability of certain women to refrain from eating for prolonged periods had been considered miraculous. ${ }^{9}$ If gluttony was a major form of lust, then fasting provided renunciation and a literal way of encountering God. ${ }^{10}$ However, medicine became recognisably modern and empirical from around 1790. Superstition and religious thought had little place in this new and blossoming medical science. Physicians came to regard an apparent ability to abstain from food more sceptically. Although fasting girls remained newsworthy, doctors now accused them of being dishonest or ill. They pathologised fasting girls as anorectic or psychologically unstable. ${ }^{11}$ As A.R. Turnbull, Medical Superintendent of Fife and Kinross District Asylum, wrote in 1895 in an article on force-feeding, published in the Journal of Mental Science, 'refusal of food may be due to mere stupidity, or to the restlessness and inattention of maniacal excitement; much more frequently it is seen in cases of melancholia, melancholic stupor or delusional 
insanity'. ${ }^{12}$ Fasting was still a public spectacle of self-enforced suffering. ${ }^{13}$ Nonetheless, doctors now saw it as a problem that demanded therapeutic intervention. In this context, asylum doctors came to recognise the usefulness of force-feeding for breaking the physical and emotional resolve of fasting girls and correcting their seemingly errant behaviour. ${ }^{14}$

When the suffragettes first went on hunger strike, force-feeding was well-established in asylums. ${ }^{15}$ It had gained popularity in late-eighteenthcentury France after eminent psychiatrist, Philippe Pinel, refuted a commonly held belief that insane patients never felt hungry, and therefore required little food. Believing that hunger could have a disastrous effect on the mind, Pinel instead ensured that his patients were well-nourished. ${ }^{16}$ The practice of feeding patients with an elastic tube soon became standard in French asylums. ${ }^{17}$ Nineteenth-century technological developments further promoted the use of feeding technologies. In 1868, German physician, Adolf Kussmaul, introduced the stomach tube to medical practice after perfecting the technology by experimenting on a professional sword swallower. ${ }^{18}$ Yet psychiatrists heavily debated the safety of the stomach tube. ${ }^{19}$ Despite considerable reservations, force-feeding became established as a standard therapeutic practice for halting starvation. Yet it also formed part of the disciplinary tendencies inherent in asylum practice that weighed particularly heavily upon women whose behaviour was deemed abnormal. ${ }^{20}$

While asylum physicians were perfecting their feeding technologies, groups of women were gathering together to discuss why they were not allowed to vote. In England, the Reform Act of 1832 had extended voting rights to adult males who rented propertied land of a certain value. It gave voting rights to around one in seven men. The Reform Act of 1867 extended the franchise to men in urban areas who met a property qualification, further increasing the scope of male suffrage. Campaigns for female suffrage began to surface. The Manchester Suffrage Committee was formed in 1867. In 1872, the National Society for Women's Suffrage formed. In 1897, the National Union of Women's Suffrage Societies was established, bringing together a number of disparate local and national groups. $^{21}$ Frustrated with this movement's lack of success, in 1903 Emmeline Pankhurst formed the Women's Social and Political Union (WSPU) in Manchester, a group who, by 1905, had adopted a militant approach to suffragist demands. Its members chained themselves to railings to provoke arrest, poured harsh chemicals into mailboxes, broke windows, and committed acts of arson. This recourse to violence shocked 
the British public, not least because it challenged contemporary norms of expected feminine behaviour. However, it drew considerable attention to the female suffrage cause. ${ }^{22}$

Artist and illustrator, Marion Wallace Dunlop was an active member of the WSPU. Police regularly arrested her for offenses including 'obstruction' and leading groups of women on protest marches. In July 1909, Marion stencilled a passage from the Bill of Rights on a wall of the House of Commons which read: 'It is the right of the subject to petition the king, and all commitments and prosecutions for such petitioning are illegal'. Police once again arrested her. Upon entering Holloway Prison, the prison authorities rejected Marion's application to be placed in the first division (which would have acknowledged her offense as political). Entirely on her own initiative, Marion decided that she would refuse to eat until her demands were met. She found herself released from Holloway after just four days. Prison staff feared that she might otherwise starve. ${ }^{23}$

What seemed at the time to be an inconspicuous episode in the ongoing campaign for female suffrage escalated into years of controversy over the management of hunger strikers. The WSPU quickly realised the strengths of hunger striking. The tactic fitted well with the burgeoning ethos of self-sacrifice attached to the militant campaign; hunger striking was underscored by an explicit threat of martyrdom. From 1909, other imprisoned suffragettes imitated Marion. In turn, hunger striking evolved into a standard political protest. ${ }^{24}$ These protests immersed prison authorities and the Home Office in a highly problematic predicament. Two options were left open to them: allow rebellious politicised prisoners to slowly commit suicide or release them before the completion of their sentences. Both could have proven publicly distasteful. Initially, the Home Office chose the latter option, but criticism mounted during summer 1909. The simple act of refusing to eat was undermining the workings of the prison and judicial system, raising concern that all manner of prisoners-even murderers and sex offenders-might go on hunger strike to secure release. The Home Office required an alternative solution.

In September, Charlotte Marsh, Laura Ainsworth, and Mary Leigh were arrested while demonstrating at a public meeting being held by Prime Minister Herbert Asquith. A judge sentenced them to two weeks imprisonment at Winson Street Gaol, Birmingham, where the prisoners immediately went on hunger strike. One Saturday afternoon, a wardress entered Mary Leigh's cell and forced her onto her bed. Two doctors entered the room. While Mary was being pinned down, one of the doctors inserted a 
tube into her nose with a funnel at the end. The tube had a glass junction in the middle that allowed the doctor to see if liquid was passing through. The doctors pushed over twenty inches of the tube into Mary's body while the wardresses held her down. A pint of milk and eggs was then poured into the tube. For Mary, the sensation of being fed was intensely agonising. She suffered throat and breast pain and a distressing sense that the drums of her ear were bursting. ${ }^{25}$ Mary believed that force-feeding was illegal. It came as some surprise that her prison doctors had resorted to such an intrusive strategy.

Over the five years that followed, the contentious issue of force-feeding acquired considerable depth. Force-feeding was an imperfect solution. Patients who had refused food in asylums were considered insane. They had lost the rationality to make an informed decision about whether or not to eat. Prison hunger strikes were entirely different. Suffragettes tended not to be mentally ill, despite the audacious claims of some critics. ${ }^{26}$ Moreover, their decisions to abstain from eating were premeditated, deliberate, and political. Suffragettes valorised their capacity to withstand hunger as an indication of moral strength, not mental weakness. ${ }^{27}$ Their protests offered a new articulation of militant violence, albeit one directed inwardly towards the body of the female protestor.

\section{Ethical Dilemmas}

Force-feeding created a pronounced ethical debate widely discussed by doctors, suffragettes, politicians, journalists, and literary figures. Between 1909 and 1914, English prison medicine became a very public affair. Force-feeding raised problems with implications that stretched far beyond the relatively limited confines of arguments for gender equality from which they had emerged. It called into questions the nature of medical practice itself. Indeed, this can be considered one of the key strengths of hunger striking: its ability to challenge the authority of a male-dominated medical profession and state in using medical technologies to quell female political rebellion. Force-feeding evoked powerful images of hunger strikers as oppressed, vulnerable individuals unfairly stripped of political and bodily rights. Yet suffragettes did not necessarily view their subjugation by prison doctors as too incompatible with the general behaviour of contemporary medical men. Many were actively campaigning against certain medical activities. The paternalistic maledominated profession had a reputation for dealing harshly with deviant 
women, as evident in the passing of the Contagious Diseases Act (1864) which had enforced compulsory, often humiliating, venereal disease checks on arrested prostitutes. ${ }^{28}$ Suffragettes also regularly accused the profession of supporting torture, as demonstrated by its willingness to scientifically experiment on animals and, some feared, humans. ${ }^{29}$ As historian Martin Weiner argues, the disciplinary face of Victorian medicine, expressed through its support for compulsory vaccination and venereal examination of prostitutes, meant that the disciplinary tendencies of the prison medical service did not necessarily conflict with the values or world views of the medical profession more generally. Medicine and punishment had many points of affinity and contact. ${ }^{30}$

Nonetheless, for some, force-feeding was a step too far. According to critics, the usage, techniques, and instrumentation of force-feeding went far beyond the accepted boundaries of medical ethics and clinical norms that traditionally guided medical practice. ${ }^{31}$ Admittedly, the boundaries between what did and did not constitute an appropriate bodily intervention were not fully decided upon, as demonstrated by the embroilment of medical practitioners in matters such as compulsory vaccination, animal vivisection, and human experimentation. ${ }^{32}$ All of these seemed to have some discernible therapeutic value. But did force-feeding? Unlike compulsory vaccination, it did not seem to improve health or protect against disease. And unlike vivisection and experimentation, force-feeding had no clinical or research value. If force-feeding was indeed bereft of medical value, then it could easily be denounced as an unnecessary tool of discipline and punishment, as something that clashed profoundly with the intended functions of professional medicine.

Medical men had demonstrated only sporadic enthusiasm for the cause of female suffrage. Indeed, bacteriologist, Almroth E. Wright, penned damning anti-suffrage literature towards the end of the campaign that reinforced perspectives shared by many doctors on the social and biological superiority of men. ${ }^{33}$ Nonetheless, the issue of force-feeding encouraged more sympathetic members of the profession to engage with feminist concerns. According to critics from within the profession, force-feeding differed from other disciplinary forms of medical intervention as it clashed with the basic principles of medical ethics which rested on a sense of duty to patients, polite and respectful interactions with patients, and a general commitment to the welfare of society as a whole. ${ }^{34}$ But was it really the duty of prison doctors to feed to save lives? Did prison doctors perform the procedure decorously? And did the feeding of fasting prisoners 
against their wishes really benefit society? The answers to these questions appeared unclear.

The safety of force-feeding was a particularly pressing matter. If forcefeeding was dangerous, then it could hardly be considered appropriate. Prison doctors used two instruments to feed: the nasal tube and stomach tube. They occasionally used a stomach pump. Medical agreement on the physical safety of these technologies had never been satisfactorily reached. ${ }^{35}$ Nasal tubes were generally less intrusive than stomach tubes, although the more invasive stomach tube was the preferred technology of feeding. Even in normal clinical practice, patients were known to vomit and suffer from internal bruising and cutting should the tube used be too coarse. Some accidentally swallowed the tubes. ${ }^{36}$ When the Home Office first authorised force-feeding, the WSPU swiftly rallied medical support, filling pages of their newspaper, Votes for Women, with testimony which insisted that feeding practices, especially when used on resisting prisoners, could cause serious and permanent internal injury. Force-feeding, opponents vociferously declared, could cause a plethora of complaints and, on that basis, constituted a gross perversion of medical norms. It risked causing laceration of the throat, stomach damage, heart complaints, and syncope, as well as septic pneumonia should food accidentally enter the lungs, so opponents insisted. ${ }^{37}$ Expert uncertainty about the safety of feeding technologies, even in clinical contexts, granted the suffragettes opportunities to converse with concerned medical professionals who, although not necessarily attracted to the issue of female enfranchisement, felt uneasy about the state's harnessing of prison medicine. The suffrage cause and the medical profession were not obviously allied. Nonetheless, medical opinion offered a powerful resource for fortifying anti-force-feeding rhetoric.

At the heart of force-feeding controversies also rested the thorny matter of whether or not prison doctors were obliged to perform the procedure as part of their medical duty. If not, then force-feeding seemed coercive. The Home Office portrayed force-feeding as therapeutic, not penal, as an indispensable life-saving mechanism. In its view, 'artificial feeding' was safe, humane, and ethically uncomplicated; it was required to save the lives of suicidal women. To support their argument that force-feeding corresponded with asylum feeding practices, Home Secretaries always used the less sensitive, clinically detached term 'artificial feeding'. ${ }^{38}$ Yet the government was too implicated as a hostile adversary of the suffragettes for this somewhat simplistic rendering to go unchallenged. The issue of medical consent proved particularly problematic as performing a potentially 
harmful procedure on an unwilling and sane participant clearly violated one of the most basic patient rights: to be able to choose whether or not to receive medical treatment. ${ }^{39}$ If consent had not been given, then was force-feeding simply a state-sanctioned abuse of medical power? Worse still, was prison medicine being manipulated for political purposes under the auspices of saving lives? Moreover, the apparent enthusiasm of the government to intervene at the prison bedside caused considerable concern about the diminished decision-making capacities of prison physicians who had traditionally reserved a right to make their own clinical choices. ${ }^{40}$ Although, technically, prison doctors still decided whether individual prisoners ought to be fed, the overarching presence of the state at the back of these decisions energised discussion on the degree of control or persuasion that the state now held in prison medical practice.

Resolving these issues was not an easy task given a distinct absence of a firm tradition of British medical ethics. The British Medical Association had adopted an ethical code only reluctantly, while the General Medical Council was generally reticent to issue ethical guidance. ${ }^{41}$ It was widely presumed that a strict ethical system did not in fact require codifying and setting in place in Britain as practitioners there could be trusted to perform their work gentlemanly and ethically. ${ }^{42}$ Furthermore, ethical issues, where they did arise, tended to be handled internally, not in law courts or Parliament. ${ }^{43}$ Opponents of force-feeding disrupted this custom. Suffragettes thrust discussion of the medical ethical dimensions of forcefeeding into public forums, an approach that ran counter to traditional British medical etiquette which frowned upon criticism levelled against medical conduct being made in public or in the lay press. ${ }^{44}$

From 1909, various prominent medical figures offered expert opinion on the harmful effects of force-feeding and the unwarranted extension of state authority into medical autonomy. Some opposition came from predictable sources. Suffragette medical doctor, Louisa Garrett Anderson, asserted that the stomach tube was not being used to save lives, as it would be in clinical settings, but was instead being deployed to coerce militant prisoners. ${ }^{45}$ Charles Mansell-Moullin also protested. Mansell-Moullin had established a reputation for his research into shock and peptic ulcer disease, but was also married to prominent suffragette Edith Mansell-Moullin. In September, he vehemently remonstrated in the British Medical Journal against the use by politicians of the term 'hospital treatment', announcing that 'if it was used in the sense and meaning in which it appears in your columns it is a foul libel. Violence and brutality have no place in hospital' ${ }^{4} 6$ 
Both of these individuals made firm distinctions between clinical practice and hunger strike management by insinuating that prison medicine was being politically manipulated.

Notably, medical criticism was not always confined to medical men with any obvious affiliations to suffragism. It also surfaced from individuals with limited interest in votes for women but whose attention had nonetheless been captured by the ethical implications of force-feeding. Lyttelton Forbes Winslow was a controversial psychiatrist who had gained notoriety for investigating the Jack the Ripper murders, and had long argued that crime and alcoholism resulted from insanity. His interest in punishment encouraged him to write to Votes for Women stating that he had long since abandoned artificial feeding in clinical practice due to its various problems, mentioning one case where a patient had bitten off his own tongue after it had become twisted behind the feeding tube. ${ }^{47}$ Similarly, impartial surgeon Forbes Ross stated in The Observer that he considered force-feeding to be 'an act of brutality beyond common endurance'. Ross noted that it was only used in asylums as a last resort and that it almost always brought on fatal chronic pigmentary colitis. ${ }^{48}$

Nonetheless, a lack of expert consensus on the safety of force-feeding enabled the Home Office to assemble a contrasting body of medical evidence. It consulted a number of medical figures accustomed to performing artificial feeding. In October 1909, Home Secretary, Herbert Gladstone, privately acquired data from Frederick Walter Mott, pathologist to London County Council Asylum at Claybury. Responding directly to Forbes Ross' public claims, Mott claimed that he had never noticed medical complaints being brought on by artificial feeding in ten years of feeding asylum patients. ${ }^{49}$ The Home Office also maintained close contact with controversial prison medical officer, William Cassels, of Winson Street Gaol who had performed the first suffragette feedings. Cassels kept a close watch on the health of his force-fed prisoners and reported daily to the Home Office. In his private correspondence, he dismissed accusations that force-feeding caused intense vomiting. He admitted that Mary Leigh had once vomited for hours after he had fed her, but claimed that this was probably self-induced.$^{50}$ Cassels also refuted suggestions that prison doctors knowingly fed prisoners whose bodies had been severely weakened by hunger striking. Suffragette prisoners, Cassels insisted, refused to be physically examined meaning that he could hardly be held responsible if a sick patient was accidentally force-fed. Cassels recalled that Mary Leigh had refused to answer questions about her throat and nose pains. Upon 
asking to examine her tongue, Mary had flippantly answered 'I will give you enough of that when I get the vote'. Cassels carefully noted this incident. If a patient refused to provide information or be examined, then it was impossible for him to determine health problems such as a sore throat. On this matter, he stated that 'I do not believe that I should be justified in forcing the mouth open merely to see whether the throat is all right' ${ }^{51}$ The message was clear. If a patient was injured, Cassels could not be held responsible. He was merely attempting to perform his medical duties in the face of recalcitrant, hostile, and un-cooperative prisoners.

Cassels had sound reasons for highlighting his professionalism. Upon leaving the prison, Mary Leigh took the brave step of taking legal action against Cassels and Gladstone for unlawful assault. Mary was faced with the formidable problem of taking on the Home Office. She was in a disadvantageous position. Ultimately, the official stance on 'artificial feeding' as curative and life-saving was formally confirmed during the proceedings of Leigh $v$ Gladstone. The outcome of the trial would continue to be referred to throughout the century in various hunger striking contexts. At the proceedings, witnesses made efforts to negotiate the contested boundaries between treatment and torture and, by extension, establish whether the state was brazenly harnessing prison medicine. Witnesses discussed key questions raised in the public debate on force-feeding. Firstly, did force-feeding have potential health implications? Predictably, Cassels insisted that harm only resulted if patients refused medical inspection or struggled, adding that vomiting was always self-induced. Confirming this, Guy's Hospital physician, Maurice Craig, claimed to have fed patients up to 2500 times at Bethlem Hospital without having witnessed a death or problematic symptoms, such as heart disease, indigestion, or gastric ulceration. Accordingly, prison doctors who force-fed were cast as innocent of charges of wilful assault. Secondly, did prison medical practice correspond with asylum practice? One witness claimed that rectal feeding was a more common hospital procedure, although the feasibility of performing this on imprisoned suffragettes was dismissed as 'to do it [feeding] by rectal treatment would mean holding her legs and subjecting her to great indignity ... in the presence of both men and women'. Issues of feminine delicacy and decorum indicated that feeding via the mouth or nose would remain the most appropriate form of treatment. Thirdly, and importantly, was force-feeding compliant with the prison doctor's ethical duties to save lives? Witnesses concluded that doctors did indeed have a basic responsibility to preserve health and life and were not obliged to pay damages 
to prisoners. None of the medical witnesses could decisively decide upon when death was likely to occur or, in view of that, when force-feeding should commence. Accordingly, compulsory feeding at an early stage was advised to ensure that time did not elapse for starvation to bring on serious physical debilitation. ${ }^{52}$

Evidently, the opening months of the suffragette hunger strikes opened up a number of medical ethical problems that still bear relevance. Then, as now, critics alleged that force-feeding amounted to torture, adding that the act was inherently political and constituted a serious breach of medical ethics. Opponents focused on the physical harm caused by force-feeding and challenged the right of doctors to perform the procedure. The implementation of force-feeding also established the role of the prison doctor as arbiter between the state and its prisoners, as the individual, in the eyes of critics, expected to perform the actual act of physical subjugation.

\section{The Loyalties of Prison Doctors}

Force-feeding was far more than a technical issue in medical ethics. Critics considered the force-fed suffragette body in light of contemporary sensibilities towards pain and suffering. In the nineteenth century, the infliction of pain had been considered relatively acceptable in prisons. It was considered important to character reformation. Physical and emotional suffering, it was believed, helped to cure immorality. ${ }^{53}$ Yet ideas changed considerably from the mid-Victorian period onward. Suffering lost much of its religious connotations in an increasingly secular society. ${ }^{54}$ Moreover, medical innovations such as anaesthesia made pain less common. As the threshold of public sensitivity to pain lowered, the idea that it was being wilfully inflicted by members of a respectable profession made forcefeeding seem all the more shocking. ${ }^{55}$ The idea that the government had over-ruled medical autonomy in prisons to support such actions caused further provocation, as demonstrated by Frank Moxon in his impassioned outcry against force-feeding.

Force-feeding also raised concern about the willingness of the state to use prison medicine to help tackle political dissidence by enforcing physical and psychological discipline. The enactment of discipline with what was easily interpreted as a painful and degrading assortment of medical techniques proved particularly challenging for liberals who considered force-feeding to be at odds with their natural political impulses. When tendering his resignation from the Liberal Association in October 1909, 
Reverend Lloyd Thomas angrily announced that, by resorting to the stomach tube, the government 'offers the violated bodies of these highminded women as a living sacrifice to the obstinacy of the Prime Minister and a few of his colleagues'.$^{56}$ Lady Blake resigned from her presidency of the Berwick Women's Liberal Association in the same month, proclaiming that she could no longer maintain her connection with the Liberals. ${ }^{57}$ A particularly well-publicised response came from Henry Brailsford and Henry W. Nevinson in 1909. When resigning as editors of Liberal newspaper The Daily News, they condemned the forceful use of the stomach tube as an instrument of punishment, questioned its life-saving value, and announced that they would no longer continue denouncing torture in Russia while supporting it in Britain. ${ }^{58}$ This evaluation was far from accidental: It tapped into a discourse likely to gain a strong reception within a liberal culture that tarred Tsarist Russia with labels of otherness and authoritarianism, partly to promulgate faith in the civilised nature of modern British society and its cultural ideals. ${ }^{59}$ In fact, hunger strikes were then a novelty in Britain, having only been heard of in Russia. Furthermore, Russian hunger strikes were widely agreed upon in Britain as necessary acts of militancy in the face of a barbaric and inhumane government. ${ }^{60}$ The adoption of force-feeding strategies in a country that preferred to present itself as the antithesis of all that was wrong with Russia-as liberal, civilised, and modern-infused anti-force-feeding rhetoric with deep cultural resonance. For liberals, the infliction of pain called into question basic tenets of western, civilised society itself. ${ }^{61}$

The suffragettes found various opportunities to express their views on the unprofessional nature of force-feeding. Apparent lapses of medical professionalism allowed them to emphasise their suffering at the hands of prison doctors. Many maintained that medical staff had eagerly (rather than reluctantly) tortured and degraded them. They presented the stomach tube as a disciplinary technology used daily solely to rectify deviant behaviour and punish prisoners who refused to conform. It is difficult to assess whether prison doctors truly believed in their ethical duty to intervene for the sake of saving lives, if they played upon this suggestion when justifying their actions in the face of negative publicity or if some found sadistic pleasure in assaulting female prisoners. Most did not speak publicly about their actions. Information about them can be gleaned primarily from propagandist sources such as Votes for Women, a publication whose authors had reasons to portray doctors as wilful perpetrators of violence. What seems clear is that evocative images of suffering and medical torture 
cast doubt on the professionalism of members of a trusted, learned profession allowing a clear sense of antagonists and victims to emerge.

This was problematic for the prison medical community. From around the late 1880s, the English prison medical service had strove to be more attentive to prisoner health. ${ }^{62}$ More generally, conceptions of crime and its management had gradually moved away from a harsh mid-Victorian obsession with 'reforming' immoral members of society by punishing. Ideas about rehabilitation increasingly infiltrated social thought on crime, meaning that prisons were seen as ideally serving a restorative, rather than solely punitive, function. ${ }^{63}$ Contemporary anti-force-feeding propaganda challenged progressive images of prison medicine's new functions by re-casting the work of the prison doctor in a more ambiguous light. Upon release, force-fed suffragettes cast dispersions on prison doctors by exposing their compliance with, if not sheer enthusiasm for, force-feeding. These propagandist renderings, in turn, implied that prison doctors were willingly conspiring with the coercive agendas of the state. These claims were potentially damaging, given their appearance in a period when prison doctors were motivated to professionalise, in a timeframe when, as Joe Sim details, they sought to distance their institutional work from disciplinary duties by campaigning for better pay and taking on more sophisticated psychiatric and therapeutic duties. ${ }^{64}$

Problematically, from late 1909, released prisoners not only complained of a range of physical problems brought on by the use of feeding technologies, but also made strong accusations about their encounters with prison doctors. If anything, doctors seemed to be carelessly damaging the health of female prisoners. Rather than benevolently offering therapy, they seemed intent on restoring institutional order regardless of the levels of physical force and harm needed. Hannah Sheppard was force-fed at Strangeways while suffering from a stomach ulcer. Despite her condition, Sheppard endured a fortnight of being fed before capitulating by resuming eating. Eventually released, physically and emotionally weak, Sheppard was deposited late at night outside a WSPU office. ${ }^{65}$ Sheppard was imprisoned alongside Helen Liddle, who recounted her experiences of being forcibly fed as follows:

I consider the medical treatment as an absolute farce; the senior medical officer was perfectly brutal, short-tempered and very rough. My chief accusation is against the senior medical officer for his use of the gag; by the end of the second week my mouth was so painful and swollen, inside and outside, that two wardresses noticed it. My lip was gathering, and the whole 
operation was so painful and repulsive and needlessly cruel that two of the wardresses went away four times, sick and faint. They complained of sick headache ... the last week they fed us by the nasal tube, pouring down a whole quart of liquid at a time, causing great discomfort for hours and a curious feeling in the ears which seemed to make speaking difficult. ${ }^{66}$

Another female prisoner recalled how she had once overheard her doctor exclaiming that 'this is like stuffing a turkey for Christmas', indicating an inappropriate amount of joviality, if not sadism. ${ }^{67}$ Lillian Lenton declared in Votes for Women that:

If forcible feeding is at once intensely painful, highly dangerous and altogether futile as to achieving its avowed object there is only one name by which it can be designated and only one purposed which it can be intended to serve. It is torture, carried on by those on whom it is inflicted. As such it is repugnant to all modern ideas of punishment, and is a return to the dark ages of barbarism. ${ }^{68}$

Similarly, members of the Pankhurst family later insisted that forcible feeding was coercive and torturous. Christabel Pankhurst described the procedure as a violent and painful assault. ${ }^{69}$ In 1912, Sylvia Pankhurst claimed that some force-fed prisoners had been handcuffed, thrown into dark, damp punishment cells, frog-marched, beaten, and bruised..$^{70}$ In 1913 , Sylvia Pankhurst was herself force-fed. Drawing clear parallels with rape, she described her experiences in Votes for Women as follows:

When six women had got me on the bed, holding me by the ankles, knees and shoulders, the doctors came stealing in. They hadn't the courage to show themselves until I was securely held. Somebody caught me by the head from behind and tied a sheet under my chin. I set my teeth like a vice and my breath came so quickly that I thought I should suffocate. I felt a man's hand trying to force my mouth open. I felt a steel instrument being forced against my gums, where I had had two teeth out. I fought against it with all my strength, but cutting its way into the flesh, it worked its way in, and then they turned a screw, which gradually forced my jaws apart. It felt as though I were having my teeth drawn. They then started to force the tube down my throat. I tightened the muscles and struggled with all my might. Presently they said, "That's all," and dragged out the tube. It was quite a long time before I could get my breath. They left me on the bed exhausted and shaking with sobs. The same thing happened in the evening, but I was too tired to fight so long. So it went on day after day. ${ }^{71}$ 
These accounts deeply problematised the official stance on 'artificial feeding' by casting medical officers as individuals knowingly subverting the natural therapeutic agendas of their profession by wilfully inculcating pain and harm. Suffragette propaganda portrayed prison doctors as individuals refusing to act in the gentlemanly, decorous fashion expected of members of their profession.

Following the Leigh $v$ Gladstone outcome, the suffragette movement actively sought to refute the uncomplicated, official stance on 'artificial feeding' and its therapeutic benefits. WSPU propaganda continuously cited examples of abuse, neglect, and brutality deliberately inflicted upon prisoners intended to discredit the character of prison doctors. Although few doctors spoke out against these insinuations, in January 1910, William Cassels sceptically commented in the British Medical Journal that Laura Ainsworth's voice was no more 'weak and husky' after being force-fed than when she had entered the prison, despite her complaints of throat ache. He also suggested that Hilda Burkitt, despite having publicly lamented her severe physical weakening in prison, had once privately informed him that, when alone, she would waltz around the polished floor of the hospital ward. Hilda had also frequently announced to Cassels that she felt fit enough to take on ten policemen. ${ }^{72}$ Cassels voiced his public statements in the face of frequent attacks being made upon his home, which the WSPU proudly reported in Votes for Women as being besieged daily by its members. Since the previous September, his house had been guarded day and night by policemen to protect him against crowds of fuming women assembled outside with sandwich boards. ${ }^{73}$

Evidently, the work of prison doctors such as Cassels became increasingly disrupted by female militancy. But perhaps it was the case that Cassels felt sickened at the thought of women starving to death en masse in his workplace? Perhaps he genuinely believed in his duty to prevent such an emotionally perturbing scenario, even if this did involve performing a harmful procedure? And could his hostility have been caused by impatience at dealing with a set of stubborn, un-cooperative women who steadfastly refused his medical assistance and subjected him to insults, resistance, and public criticism? The image of Cassels as torturer was certainly provocative, but this image could have concealed a far more complex range of emotions felt by him when called upon to force-feed and avoid group death.

Nonetheless, further claims about prison treatment continued to cast negative light on the character of prison doctors. Lady Constance Lytton was a particularly prominent suffragette, being the daughter of Robert 
Bulwer-Lytton who had once proclaimed Queen Victoria as the Empress of India. Her mother, Edith Villiers, had acted as Queen Victoria's ladyin-waiting. In 1909, Constance was imprisoned at Newcastle Gaol but was prematurely released after just a few force-feedings after being diagnosed with a weak heart. Yet Constance believed that she had been given preferential treatment due to her prominent social status. Working-class suffragettes, Constance alleged, remained imprisoned and force-fed for much longer periods as they had limited social influence. Their fate in prisons was less likely to be heard. Constance insinuated that the state, fully aware of its dubious legal and moral rights to force-feed, was less inclined to inflict pain upon those like herself with a louder social voice. But if prison doctors were truly performing medical duties by force-feeding, surely these were meant to extend to all patients equally, regardless of class or fame? Angered by Gladstone's formal debunking of her claims, Constance bought a set of clothes commonly worn by working-class females, adopted the pseudonym of Jane Warton, and deliberately got arrested and imprisoned. ${ }^{74}$ The treatment given to 'Jane Warton' differed remarkably to that given to Lady Constance Lytton, whose supposed weak heart had led to a hasty release just months earlier. She observed that 'Warton's' heart was not examined until after her third feeding, and claimed that her doctor once slapped her across the cheek..$^{75}$ Lytton/Warton's experiences were reported nationally. In keeping with broader concerns about the emerging trajectories of liberal policy, The Law Times complained of gross preferential treatment and 'a peculiar perversion of justice' that 'savours overmuch of Russia'. ${ }^{76}$

Accounts of Constance's plight illustrate the inherent duality of constructions of the prison doctor that materialised during the suffragette force-feeding controversy. These typically juxtaposed him as either fulfilling normal ethical duties or distorting them by engaging in political subjugation. These negative depictions openly queried the English medical profession's preferred image as decorous and gentlemanly. They also sought to instil a sense that prison medical behaviour ran counter to the norms of Edwardian medicine, accompanied as it now was with physical violence, verbal intimidation, and limited concern over health risks. The claims made by suffragettes were undeniably propagandist in nature. However, their intent determination to depict prison doctors in a negative light highlights the precarious position in which prison doctors found themselves placed (and often still do) upon involving themselves in forcefeeding. During the Edwardian period, the prison doctor's voice was 
seldom heard-Cassel's public statements being a notable exceptionwhich, in itself, might speak volumes about their unwillingness, or inability, to publicly challenge state commands. It is also likely that some prison doctors, as the accounts of Constance Lytton and others imply, rendered them unsympathetic to the physical and emotional well-being of troublesome, recalcitrant prisoners whose unruliness disrupted the daily norms of prison medical practice, resulting in harsher institutional attitudes towards those prisoners and a willingness to inflict pain and abuse.

\section{Bodies, Minds, and Stomach Tubes}

The later years of suffragette hunger strike management saw the production of constantly evolving propaganda narratives that strove to find new ways of confirming the damaging physical and emotional effects of force-feeding. Leigh $v$ Gladstone had provided legal precedence to suggestions that forcefeeding was safe and ethically appropriate, effectively castigating suffragette contestation as hyperbolic. In response, opponents stepped up their efforts to connect feeding practices to ill health and reveal them as a gross bodily and mental assault. In light of this, new problems were raised: Does force-feeding have potential psychological and emotional implications? Can it directly cause illness or hasten pre-existing conditions? And finally, is it appropriate to force-feed physically or mentally disadvantaged individuals? The very existence of these concerns highlights the ethical complexity that the issue of force-feeding acquired in a remarkably short timeframe.

In March 1910, the government implemented Rule 243a, awarding suffragettes special privileges in prison, including more regular visits, permission to wear their own clothes, and better food. Force-feeding ceased, at least temporarily. However, in 1911, a further controversy erupted when Alfred Abbey, member of the Men's Political Union, was force-fed. Alfred had gone on hunger strike to protest against not being awarded special treatment on the basis that he was male. From Christmas Day 1911, a fellow prisoner-William Ball—went on hunger strike in protest against Alfred's treatment. By February, William believed that he was being tormented by electricity. Although his imaginary fears of electrical torture subsided, he began smashing his prison windows under an illusion that a detective was waiting outside for him. Some weeks later, William announced to his prison officials that he no longer minded the electrical torture so much, but objected vehemently to the needle torture that he was now being subjected to. ${ }^{77}$ 
Exactly what might have caused Williams's apparent insanity was heavily disputed. His wife pointed out that William had once been a fine athlete and had never suffered any serious illness, physical, or psychological. ${ }^{78}$ Angered by William's plight, the Men's Society for Equal Rights distributed various leaflets with titles including The Case of William Ball: Official Brutality on the Increase and Imprisoned under a Liberal Government. The WSPU printed one entitled Torture in an English Prison. ${ }^{79}$ These publications further characterised British penal institutions as out of step with the agendas of a modern, liberal country. Christabel Pankhurst announced: 'Has the Russian government ever devised so infamous a procedure as the persons responsible to the present Liberal Government!' ${ }^{80}$ In the House of Commons, Lord Robert Cecil asked what might have driven William insane, although his insinuation that force-feeding had caused mental illness was firmly rebutted. ${ }^{81}$ Home Secretary, Reginald McKenna, suggested that William's mental balance had been upset 'by his mind, apparently never a strong one, dwelling continually on the questions of votes for women and political prisoners', an announcement met with universal laughter. ${ }^{82}$ Despite such underlying joviality, an official investigation followed, and a white paper was published which concluded that William 'was kindly and properly treated, and his insanity could not be attributed to any treatment to which he was subjected' ${ }^{83}$ The Manchester Guardian derided the report as unsatisfactory as it offered no cross-examination of the Home Office or prison officials, despite them being accused of wrongdoing. The newspaper also denounced the report for refraining to speculate on what else might have caused William's mental deterioration, given that force-feeding and insanity had suspiciously commenced simultaneously. ${ }^{84}$ Nonetheless, official investigations cleared attending medical officers of blame for neglect or negligence and dissociated William's mental disorder from force-feeding. ${ }^{85}$

William's case proved useful as it enabled opponents to portray forcefeeding as a harmful mechanism of emotional, as well as physical, torture. William's pitiful fate strengthened arguments against the procedure, further calling into question the therapeutic nature of prison feeding practices. State policies could now be powerfully depicted as intent on infiltrating the psyche of suffragette prisoners as well as their bodies. Ultimately, however, little firm evidence could be procured that forcefeeding could cause insanity. Certainly, the severity of Ball's delusions suggests that he was already suffering from an underlying mental condition that had previously evaded diagnosis. But even if direct connections could 
have been convincingly proven, less sympathetic opinion might well have insisted that William had brought on his condition himself by refusing to eat in the first place. Revealingly, when it was reported in the House of Commons in August 1912 that a woman had been discharged after becoming hysterical during a feeding, universal laughter followed. ${ }^{86}$ When Emily Davison dramatically flung herself from the top floor of the prison after being fed-crashing onto a set of stone stairs-politicians expressed little sympathy. ${ }^{87}$

Politicians also disregarded medical investigations into the damaging effects of force-feeding. In 1912, Charles Mansell-Moullin joined forces with dermatologist, Agnes Savill, and renowned surgeon Victor Horsley to pen an extensive report into force-feeding, subsequently published in the Lancet. The authors provided a powerful indictment of force-feeding, detailing a range of physical and emotional effects upon the nervous system including neurasthenia. The report also identified the mental anguish produced by hearing the cries, choking, and struggles of their friends as psychologically traumatic. The authors asserted that Home Secretary, Reginald McKenna, had persistently deceived the public by claiming that 'artificial feeding' was safe and had relied upon reports sent to him by prison doctors that underplayed the extent of physical and mental suffering involved in feeding hunger strikers. ${ }^{88}$

Privately, the Home Office came to believe during 1913 that the WSPU was encouraging 'abnormal and neurotic' individuals to commit crimes likely to result in imprisonment to increase the movement's chances of securing martyrdom. ${ }^{89}$ Militants, the Home Office feared, were being specially selected to commit punishable crimes who were 'weaklings suffering from physical defects in order to cause as much embarrassment as possible to the authorities'. One confidential government report determined that the health of recently imprisoned female prisoners fell far below the average of the general population. Types thought to have been chosen ranged from the dyspeptic, people with histories of fits, those who had suffered a nervous breakdown, the 'mentally unstable', and the 'eccentric'. ${ }^{90}$

While the reality of these suggestions remains unclear, one suffragette, May Billinghurst, gained national press coverage, a paralytic who relied upon a wheelchair. Despite her condition, she was force-fed. The emotive image of a female cripple being subjected to the procedure aroused considerable sympathy. ${ }^{91}$ Similarly, the Home Office described Margaret James-sentenced to six-months imprisonment in 1913 for shop-breaking - as 'a dwarf, an epileptic, and a cripple, and in weak physi- 
cal condition'. According to Leigh $v$ Gladstone, prison medical officers were only immune from liability if fatal or serious consequences of forcefeeding could not reasonably have been expected to manifest. ${ }^{22}$ However, the Home Office feared that if she [Margaret] is left to die, there would, in the case of such a miserable weakling, be not only an outburst of public indignation, but possibly criminal proceedings might be taken by her friends against the prison authorities'. Medical officers feared that, if forcefed, epilepsy and mental excitement might ensue, firmly tipping James over the borderline to insanity. However, Margaret was not considered certifiably insane. Problematically, Reginald McKenna viewed releasing Margaret as undesirable as Margaret was 'just the sort of woman who would repeat her offence as soon as she got out, and while in prison she has used threats of shooting and violence which the Prison Officers regard as serious'. McKenna privately sought legal advice. ${ }^{93}$ In many ways, this suggests that medical officers, and the Home Office, were becoming (privately) aware of the potential psychological and physical ramifications of force-feeding and fearful of conclusive evidence being provided of the dangers of force-feeding. ${ }^{94}$

In the face of organised opposition and public scepticism, during 1913, the government introduced the Prisoners (Temporary Discharge for Ill Health) Act or the 'Cat and Mouse Act'. ${ }^{95}$ This was also implemented in response to the unmanageable burdens that hunger striking was placing on the prison system. The Act effectively legalised hunger striking, specifying that fasting prisoners should be released upon falling ill, but then later re-arrested to complete their sentences. If these prisoners resumed hunger striking, they were to be once again released upon falling ill. ${ }^{96}$ The government's reputation, already tarnished by public uncertainty about the Cat and Mouse Act, was not improved by recourse to increasingly drastic disciplinary feeding methods throughout 1914 including the alleged drugging of prisoners including Mary Richardson and the rectal feeding of Frances Gordon. ${ }^{97}$ By this point, the medical community had developed a more sophisticated network of protest, having set up the Forcible Feeding Protest Committee of Medical Men who intervened in such cases. The Committee also investigated incidences of non-suffragette hunger striking including the case of a male prisoner who was force-fed 230 times before a magistrate ordered his confinement in an asylum where he resided for four months. ${ }^{98}$ The Committee found no evidence of insanity. ${ }^{99}$

The basic medical ethical questions posed from 1909-focusing on issues such as the safety of force-feeding, medical collusion with the 
state and the claim that harm was being done to patients-were gender neutral. The problems at stake bore equal relevance to both male and female patients. Yet the fact that force-feeding was mostly performed on female prisoners proved particularly emotive and helped to propel the issue to public attention in this initial period when ethical debates were formed. In the act of force-feeding, broader socio-political debates were played out directly on the female body. By playing upon the gendered aspects of force-feeding, militant suffragettes proved adept at drawing out the emotive issue of inflicting pain upon a woman.

For instance, throughout their campaign, the movement published evocative posters at election times. Figure 2.1 is a poster entitled 'Torturing Women in Prison' produced during the 1913 by-election. It features an anonymous female prisoner being held down and nasally fed by a seemingly soul-less prison doctor whose penetrating, macabre eyes gaze at the milk which he is pouring into the feeding funnel. The prisoner is held down by a female wardress and clutched at the neck by a gentlemanly figure. The patient lies death-like and defenceless, her chair falls backwards as she repels from the tube. The poster is stripped of any sense that a valid medical procedure was being performed; the perpetrators of violence show no emotion or remorse at their actions (Fig. 2.2).

A similar image was produced in Emmeline Pankhurst's The Suffragette depicting a terrified female prisoner pinned to her chair. Her perpetrators are dressed in black, their faces hidden by the darkness of the night. The suffragette is dressed in white, implying a spiritual goodness that contrasts with the evil being performed by her perpetrators.

The ethical issues surrounding force-feeding arose in a specific sociocultural context in which the bodies of militant women came to serve as a site of conflict between the state and its political opponents. In many ways, the feeding of politically motivated women against their will represented the ultimate expression of contemporary gender relations. Force-feeding was performed at the will of a male-led government and male prison doctors. In attempting to reassert authority over her own body, the hunger striking female found herself subjected to a physical procedure that, in her accounts, shared similarities to oral rape as it was accompanied with force and intimidation. Although force-feeding acquired public prominence in this period as it was mostly performed on female bodies, the debates and questions raised were to be played out throughout the twentieth century in a number of socio-cultural and national contexts in which men were more likely to be force-fed. 


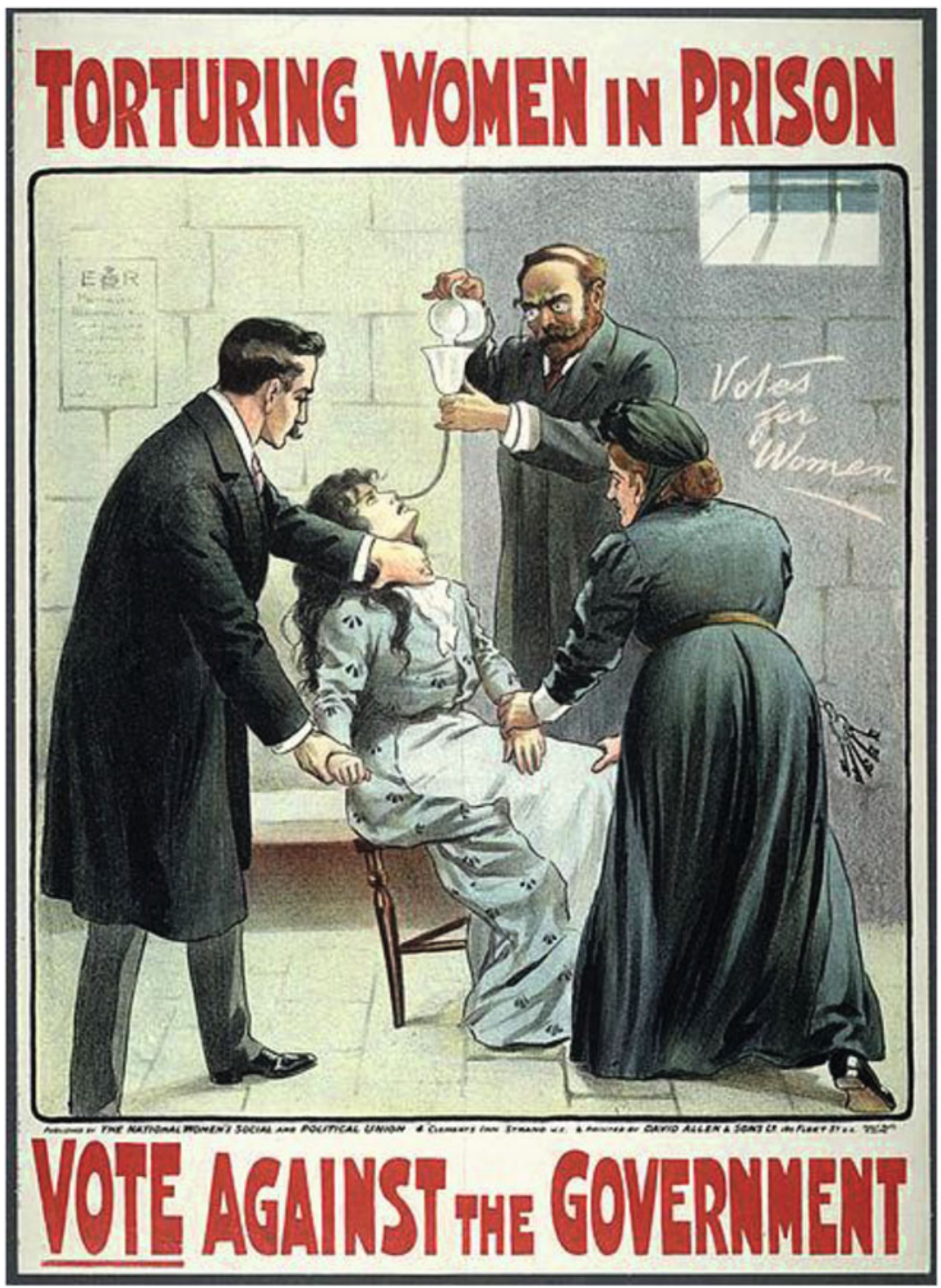

Fig. 2.1 Torturing women in prison: vote against the government. (Poster published by the National Women's Social and Political Union (London: David Allen and Sons, 1913)). All rights reserved. 


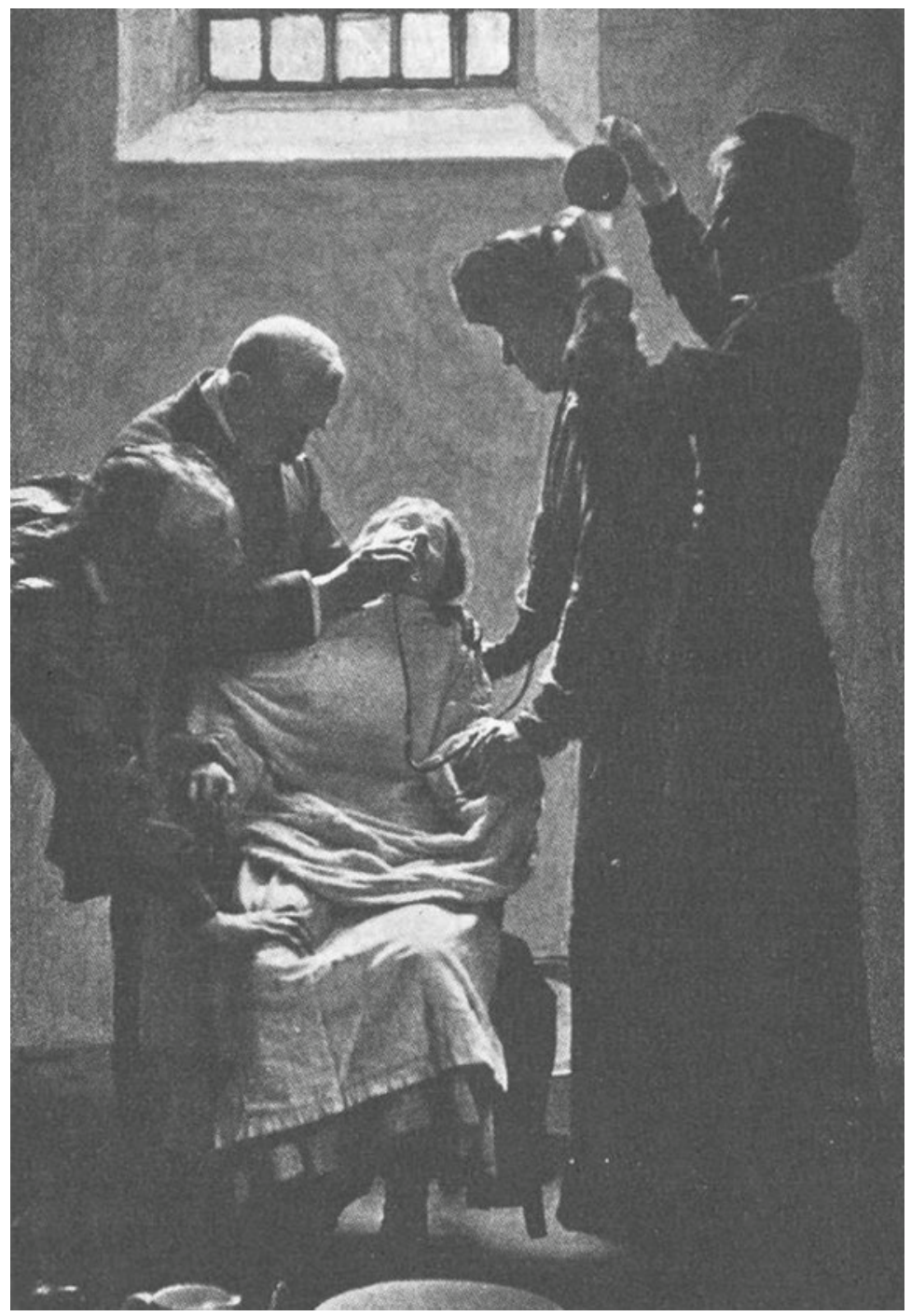

Fig. 2.2 A suffragette is force-fed in Holloway Prison (Emmeline Pankhurst, The Suffragette (New York: Sturgis and Walton Company, 1911), p. 433). All rights reserved. 


\section{CONCLUSION}

The suffragette hunger strikes ceased as war commenced, meaning that neither pro- nor anti-force-feeding campaigners ever achieved a clear opportunity to prove once and for all that prison feeding was either therapeutic or torturous. Nonetheless, it seems clear that medical opposition to hunger strike management subtly evolved between 1909 and 1914 as opponents posed new ethical problems and as new bodily and emotional scenarios emerged. Far from remaining static, discussion of the medical dimensions of force-feeding perpetually mutated, constantly offering new claims about physical and emotional harm. This facilitated the development of an increasingly multifaceted interplay between the state, prison doctor, and prisoner-patient. In this period, the Home Office proved more interested in exempting itself from legal action. Opponents were more concerned with bringing to an end what they perceived to be a coercive tactic with detrimental bodily ramifications. The most sophisticated medical critiques were published towards the end of the campaign, a somewhat inopportune time given that the public was now distant from the initial shock of forcefeeding. Public interest had waned considerably. Nonetheless, opponents had laid down a particular set of questions about force-feeding that helped to set the practice apart from normal therapeutic care.

Between 1909 and 1914, the core questions at the heart of forcefeeding debates were rehearsed for the first time. These related to whether or not force-feeding amounts to torture, if prison doctors who force-feed act autonomously or on behalf of the state and if the procedure is actually safe. The suffragette hunger strike campaign rendered visible the potential physical and emotional hazards of the procedure, particularly when performed on struggling patients. It also demonstrated the complex role of prison doctors called upon to force-feed. Doctors such as William Cassels found themselves publicly accused of torture and brutality. Outraged suffragettes publicly reported any signs of physical abuse, verbal intimidation, or emotional breakdown and probably invented many others. The debates gained prominence in light of modern western sensitivities towards the infliction of pain and concern about the nature of medical power in early twentieth-century societies. The idea that women were being subjected to an allegedly painful procedure further guaranteed high public interest in suffragette force-feeding. Critics also pointed to other ethical issues such as the potential of force-fed individuals to go insane, the ethical acceptability 
of feeding wheelchair-bound women against their will, and the apparent targeting of voiceless working-class women.

The debates about force-feeding discussed in this chapter were played out against the socio-cultural norms and ideas of the time. Dubious aspects of prison medicine could be linked to broader paternalistic moralising tendencies in medicine that acted unfavourably on vulnerable women such as compulsory venereal disease testing. Prison doctors force-fed suffragettes in a period when ideas on medical ethics were relatively unformed in comparison to the bioethics of today and when prison medicine itself was hardly considered as the most professional role within medicine. Nonetheless, basic ethical questions emerged that were to resurface in various geographical, socio-cultural, and political contexts in which hunger striking occurred throughout the remainder of the century. For western societies, force-feeding raises particular questions about civility, pain, and medical professionalism that clash with expectations of what our society is meant to be like. Torture and brutality are acts supposedly perpetrated in less civilised nations whose seemingly lower standards are often seen as worth waging wars for. The idea that western governments willingly support the torture and degradation of political opponents arouses much sympathy and compassion, appealing to the emotional economies of western society in which trust is placed on medical professionals and governments to behave decorously and ethically.

\section{Notes}

1. I use the modern term 'force-feeding' throughout unless quoting directly from primary material. The term 'forcible-feeding' was used until the 1970s when it was gradually replaced with 'force-feeding'. The term 'artificial feeding' will be used when referring to government perspectives or to the therapeutic use of the medical procedure without force.

2. http://bma.org.uk/working-for-change/international-affairs/ human-rights/guantanamo-force-feeding. Accessed 22 October 2015.

3. Bernadette Gregory, 'Hunger Striking Prisoners: The Doctors' Dilemma', British Medical Journal, 331 (13 October 2005), p. 866.

4. Frank Moxon, What Forcible Feeding Means (London: The Women's Press, 1914), pp. 4-5.

5. Ibid.

6. June Purvis, 'Prison Experience of the Suffragettes in Edwardian Britain', Women's History Review, 4 (1995), pp. 103-33. 
7. Geddes, 'Culpable Complicity'.

8. Miller, 'A Prostitution of the Profession?'.

9. Joan Jacobs Blumberg, Fasting Girls: The Emergence of Anorexia Nervosa as a Modern Disease (Cambridge, M. A. and London: Harvard University Press, 1988), pp. 41-60.

10. Caroline Walker Bynum, 'Fast, Feast and Flesh: The Religious Significance of Food to Medieval Women', Representations, 11 (Summer 1985), pp. 1-25.

11. Blumberg, Fasting Girls, pp. 61-100.

12. A. R. Turnbull, 'Some Remarks on the Forcible Feeding of Insane Patients', Journal of Mental Science, 41:175 (October 1895), pp. 64656 on p. 646.

13. Sigal Gooldin, 'Fasting Women, Living Women and Hunger Artists: Spectacles of Body and Miracles at the Turn of a Century', Body and Society, 9:2 (June 2003), pp. 27-53.

14. Blumberg, Fasting Girls, p. 104.

15. Chaney, 'Fat and Well'.

16. For broader discussion of psychiatric ideas on the mind and food, see Ian Miller, 'Food, Medicine and Institutional Life in the British Isles, c.1790-1900', in Carol Helstosky (ed.), The Routledge History of Food (London: Routledge, 2015), pp. 200-19.

17. Elizabeth A. Williams, 'Stomach and Psyche: Eating, Digestion and Mental Illness in the Medicine of Phillipe Pinel', Bulletin of the History of Medicine, 84:3 (Fall 2010), pp. 358-86 on pp. 378-83. See also Elizabeth A. Williams, 'Neuroses of the Stomach: Eating, Gender and Psychopathology in French Medicine', Isis, 98 (March 2007), pp. 54-79.

18. Theodore H. Bast, The Life and Times of Adolf Kussmaul (New York: P. B. Hoeber, 1926), p. 100. For a broader overview of the development of gastric technologies, see Ian Miller, 'Necessary Torture?'; Miller, Modern History of the Stomach, pp. 57-80.

19. See Elizabeth A. Williams, 'Gags, Funnels and Tubes'.

20. Showalter, Female Malady.

21. Jill Liddington and Jill Norris, One Hand Tied behind Us: The Rise of the Women's Suffrage Movement (London: Virago, 1978).

22. Christopher J. Bearman, 'An Examination of Suffragette Violence', English Historical Review, 120 (April 2005), pp. 365-97.

23. Laura E. Nym Mayhall, The Militant Suffrage Movement: Citizenship and Resistance in Britain (Oxford: Oxford University Press, 2003), pp. 83-4.

24. 'Hunger Strike at Strangeways', Manchester Guardian (9 September 1909), p. 9. 
25. www.spartacus-educational.com/Whunger.htm. Accessed 24 April $2015,15.13$.

26. See Thomas Claye Shaw, 'The Psychology of the Militant Suffragette', Lancet, 181 (17 May 1913), p. 1415.

27. Vernon, Hunger, p. 60.

28. Judith Walkowitz, Prostitution and Victorian Society: Women, Class and the State (Cambridge: Cambridge University Press, 1980).

29. Miller, 'Necessary Torture?'; Miller, Modern History of the Stomach, pp. 61-2, pp. 79-81. See also Susan Lederer, Subjected to Science: Human Experimentation in America before the Second World War (Baltimore, M. D.: John Hopkins University Press, 1995).

30. Martin J. Weiner, Reconstructing the Criminal: Culture, Law and Policy in England, 1830-1914 (Cambridge: Cambridge University Press, 1994), p. 129.

31. For contemporary perspectives on medical ethics, see Robert Saundby, Medical Ethics: A Guide to Professional Conduct (Bristol: John Wright and Co., 1902).

32. For discussion of late nineteenth-century debates on compulsory vaccination, see Nadia Durbach, Bodily Matters: The Anti-Vaccination Movement in England, 1853-1907 (Durham, N. C.: Duke University Press, 2005). For British vivisectionism and the development of the anti-vivisectionist movement, see, among others, Roger D. French, Antivivisection and Medical Science in Victorian Society (London: Princeton, 1976); Coral Lansbury, The Old Brown Dog: Women, Workers and Vivisection in Edwardian England (Madison, Wis.: University of Wisconsin Press, 1985); Stewart Richards, 'Drawing the Life-blood of Physiology: Vivisection and the Physiologists' Dilemma, 1870-1900', Annals of Science, 43:11 (1986), pp. 27-56; Nicolaas A. Rupke, ed., Vivisection in Historical Perspective (London: Croom Helm, 1987); Susan Hamilton (ed.), Animal Welfare and AntiVivisection 1870-1910: Nineteenth Century Women's Mission (London and New York: Routledge, 2004); Paul White, 'Sympathy Under the Knife: Experimentation and Emotion in Late Victorian Medicine', in Fay Bound Alberti (ed.), Medicine, Emotion and Disease 1700-1950 (Basingstoke: Palgrave Macmillan, 2006).

33. Almroth E. Wright, The Unexpurgated Case against Woman Suffrage (London: Constable, 1913).

34. Jonsen, Short History of Medical Ethics, p. x and p. 45.

35. D. Anderson Moxey, 'Feeding by the Nose in Attempted Suicide by Starvation', Lancet, 100 (1872), pp. 444-6.

36. George A. Herschell, Manual of Intragastric Technique (London: H. J. Glashier, 1903), pp. 3-13; George M. Niles, The Diagnosis and 
Treatment of Digestive Diseases (London: Henry Kimpton, 1914), p. 170; Miller, Modern History of the Stomach, pp. 70-1.

37. 'Forcible Feeding: Opinions of Medical Experts'.

38. Moxon, What Forcible Feeding Means, p. 11.

39. 'Forcible Feeding: Opinions of Medical Experts, Grave Danger to Life Involved', Votes for Women (1 October 1909), p. 2.

40. Rothman, Strangers at the Bedside, pp. 18-27.

41. Andreas-Holger Maehle, 'Medical Ethics and the Law', in Mark Jackson (ed.), The Oxford Handbook of the History of Medicine (Oxford: Oxford University Press, 2011), pp. 543-60 on pp. 547-8.

42. Robert B. Baker, 'The Discourses of Practitioners in Nineteenth- and Twentieth-Century Britain and the United States', in Robert B. Baker (ed.), The Codification of Medical Morality: Historical and Philosophical Studies of the Formalization of Western Medical Morality in the Eighteenth and Nineteenth Centuries Volume Two: Anglo-American Medical Ethics and Medical Jurisprudence in the Nineteenth Century (Dordecht: Kluwer 1995), pp. 446-64 on p. 451.

43. Jonsen, Short History of Medical Ethics, p. 62; Roy Porter, 'Medical Ethics: History of Nineteenth-Century Great Britain', in Warren T. Reich (ed.), Encyclopaedia of Bioethics Volume Three (New York: Free Press, 1978), p. 1553.

44. Moxon, What Forcible Feeding Means, p. 4.

45. 'Fasting Prisoners and Compulsory Feeding', British Medical Journal, ii (9 October 1909), p. 1099.

46. The Times (29 September 1909), p. 10.

47. 'Forcible Feeding: Opinions of Medical Experts', p. 2.

48. 'A Doctor's Protest', Observer (3 October 1909), p. 9. See also Miller, 'A Prostitution of the Profession?', pp. 233-4.

49. National Archives, Kew (hereafter Kew), HO45/10417/183577/113, 'Letter from Frederick W. Mott to Prison Commission, Home Office', 8 October 1909.

50. Kew, HO45/10417/183577/124, 'Memorandum from Winson Street Gaol', 18 October 1909.

51. Kew, HO45/10417/183577/130, 'Memorandum from Winson Street Gaol', 20 October 1909; Miller, 'Prostitution of the Profession?', pp. 234-5.

52. Kew, HO45/10418/183577/351, 'Leigh Vs Gladstone: Medical Evidence', 7 December 1909; Leigh v Gladstone (1909) 25 TLR 139; Miller, 'Prostitution of the Profession?', pp. 235-6.

53. Weiner, Reconstructing the Criminal, p. 178.

54. Clark, 'The Sacred Rights of the Weak'.

55. James Turner, Reckoning with the Beast: Animals, Pain and Humanity in the Victorian Mind (Baltimore and London: John Hopkins 
University Press, 1980); Martin S. Pernick, A Calculus of Suffering: Pain, Professionalism and Anaesthesia in Nineteenth-Century America (New York: Columbia University Press, 1985); Weiner, Reconstructing the Criminal, p. 111; Rob Boddice (ed.), Pain and Emotion in Modern History (Basingstoke: Palgrave Macmillan, 2014); Bourke, Story of Pain.

56. Votes for Women (8 October 1909), p. 21.

57. 'The Question of Prison Treatment', The Times (1 October 1909), p. 7. For broader discussion of liberalism and female suffragism, see Martin Pugh, March of the Women: A Revisionist Analysis of the Campaign for Women's Suffrage 1866-1914(Oxford: Oxford University Press, 2002), p. 120.

58. The Times (5 October 1909), p. 8.

59. Kevin Grant, 'British Suffragettes and the Russian Method of Hunger Strike', Comparative Studies in Society and History, 52 (January 2011), pp. 113-43.

60. 'The Siberian Suicides and Hunger-Strikes', The Times (28 February 1890), p. 13; 'Poles and Ruthenes in Austria', The Times (23 February 1907), p. 5.

61. Miller, 'Prostitution of the Profession', p. 232.

62. Anne Hardy, 'Development of the Prison Medical Service 1774-1895', in Richard Creese, William F. Bynum and Joe Bearn (eds) The Health of Prisoners: Historical Essays (Amsterdam: Rodopi, 1995), pp. 59-82.

63. Martin Weiner, Reconstructing the Criminal: English Culture, Law and Policy, 1830-1914 (Cambridge: Cambridge University Press, 1990).

64. Joe Sim, 'The Prison Medical Service and the Deviant, 1895-1948', in Creese, Bynum and Bearn (eds), Health of Prisoners, pp. 102-17 on p. 106.

65. 'Releases at Manchester', Votes for Women (26 November 1909); Ian Miller, 'Suffragette Prison Experiences in Manchester and their Legacies', in Camilla Røstvik and Louise Sutherland (eds), Suffragette Legacy: How Does the History of Feminism Inspire Current Thinking in Manchester? (Cambridge: Cambridge Scholars Publishing, 2015), pp. 81-2.

66. "Miss Liddle's Indictment of 'Medical Treatment," Votes for Women (26 November 1909), p. 232.

67. 'The Treatment of Remand Prisoners', Votes for Women (4 February 1910), p. 208.

68. Votes for Women (17 October 1913), p. 32.

69. 'Methods of Violence', Votes for Women (8 October 1909), p. 12.

70. 'Miss Sylvia Pankhurst Answers Mr McKenna', Votes for Women (26 April 1912), p. 468. 
71. "Miss Pankhurst's Terrible Experiences," Votes for Women (22 March 1913), p. 369.

72. 'Forcible Feeding', British Medical Journal, i (1 January 1910), p. 50.

73. 'Protest against Birmingham Doctors', p. 122; Miller, 'Prostitution of the Profession?', p. 238.

74. Constance Lytton, Prisons and Prisoners: The Stirring Testimony of a Suffragette (London: Virago, 1988 [1914]), pp. 239-42.

75. 'The Outlook', Votes for Women (28 January 1910), p. 274.

76. As reprinted in Votes for Women (4 February 1910), p. 306. See also Miller, 'A Prostitution of the Profession?', pp. 238-9.

77. Kew, HOl44/1183/218081/2, 'Letter from P. R. Mandler, Medical Officer to Home Office', February 1912.

78. 'The Pentonville Tragedy', Votes for Women (16 February 1912), p. 303.

79. Kew, HOl44/1182/218081/23, 'Correspondence and Papers as to the Treatment of William Ball', March 1912.

80. 'The Pentonville Tragedy', p. 303.

81. 'Conviction of William Ball (Removal to Asylum)', House of Commons Debates (19 February 1912), vol. 34 cols 283-6.

82. Kew, HOl44/1182/218081/16, 'Case of William Ball', 22 February 1912.

83. George Savage, The Case of William Ball (London, 1912).

84. 'The Case of William Ball', Manchester Guardian (10 May 1912), p. 4.

85. See also Miller, 'A Prostitution of the Profession?', pp. 240-2.

86. 'Royal Arsenal, Woolwich (Minimum Wage)', House of Commons Debates (5 August 1912), vol. 41 cols 2273-91.

87. 'Release of Mr Pethick Lawrence', Manchester Guardian (28 June 1912), p. 8.

88. Agnes F. Savill, Charles Mansell-Moullin and Victor Horsley, 'Preliminary Report on the Forcible Feeding of Suffrage Prisoners', Lancet, 180 (24 August 1912), pp. 549-51; British Medical Journal, ii (31 August 1912), pp. 505-8.

89. Kew, HOl44/1721/233014/2, 'Correspondence: Forcible Feeding of Prisoners', 1913.

90. Kew, HOl44/1721/233014/12, 'Correspondence: Forcible Feeding of Prisoners', 1913.

91. For emotive public responses, see 'Letter Box Outrages: A Cripple Rescue-Worker's Defence', Manchester Guardian (9 January 1913), p. 8; 'Miss Billinghurst', Manchester Guardian (21 January 1913), p. 6.

92. Kew, LO3/439 box 25, 'Anonymous letter', 11 March 1912.

93. Kew, LO3/439 box 25, 'Letter from Secretary of State', undated.

94. Miller, 'Prostitution of the Profession?', pp. 243-4. 
95. Prisoners (Temporary Discharge for Ill-Health) Act, 1913 ( $3 \& 4$ Geo 5).

96. Vernon, Hunger, p. 65.

97. For drugging, see Kew, HOl44/305/248506/6, 'Forcible Feeding Correspondence', undated. For rectal feeding, see 'Atrocity in a Prison', Votes for Women (10 July 1914), p. 627.

98. 'From Prison to Asylum', Irish Citizen (25 July 1914), p. 2.

99. 'Prisoner who Tried the Hunger Strike: Put into an Asylum', Manchester Guardian (20 July 1914), p. 10; Miller, 'A Prostitution of the Profession', p. 244.

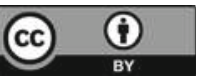

This chapter is distributed under the terms of the Creative Commons Attribution 4.0 International License (http://creativecommons.org/ licenses/by/4.0/), which permits use, duplication, adaptation, distribution and reproduction in any medium or format, as long as you give appropriate credit to the original author(s) and the source, provide a link to the Creative Commons license and indicate if changes were made.

The images or other third party material in this chapter are included in the work's Creative Commons license, unless indicated otherwise in the credit line; if such material is not included in the work's Creative Commons license and the respective action is not permitted by statutory regulation, users will need to obtain permission from the license holder to duplicate, adapt or reproduce the material. 


\section{'The Instrument of Death': Prison Doctors and Medical Ethics in Revolutionary-Period Ireland, c.1917}

Weaker and weaker grows the once muscular body of the young Republican, the curly head falls helplessly on the shrunken shoulder and the once red lips are rapidly turning blue. The tube is quickly pulled out, and Thomas Ashe's tortured stomach vomits forth some of the food that has been forced into it. The straps are unbound and the tortured prisoner falls limply forward into a state of collapse. Dr Lowe tells the warders to lead him forth and to leave him down quietly on his bed-he has done his sacred duty and has assuredly earned his five guineas! ${ }^{1}$

In 1917, emerging Irish playwright, Seán Ó’Cathasaigh (or Seán O’Casey), wrote this piercing indictment of his close friend Thomas Ashe's treatment at the hands of the medical staff at Mountjoy Prison, Dublin. Thomas was serving a two-year sentence of hard labour for sedition when he went on hunger strike in protest against the prison authorities' refusal to grant him political prisoner status. As Ó'Cathasaigh lamented, he died soon after being force-fed. Thomas's controversial death was set against a backdrop of mounting political conflict across Ireland as well as the international milieu of the First World War. This chapter examines force-feeding in revolutionary-period Ireland, and the contours added to force-feeding debates as they surfaced in a new national and socio-political context. It focuses specifically on the problem of medical participation in hunger strike management. As demonstrated in the opening chapter, the careers of English prison doctors such as William Cassels gained considerable complexity once the Home Office called upon them to force-feed. Prison doctors 
found themselves subject to public censure, accused of colluding in political agendas, and exposed to legal action. During conflicts, medical professionals are often called upon to aid political and military agendas. Many of them work in prisons and encounter highly politicised prisoners. In these circumstances, their role becomes complicated. Even in 'normal' times, prison doctors operate in a 'dual loyalty' to the ethical norms of their profession and the needs of their institution. As Joe Sim argues, prison doctors have always proactively helped to enforce discipline; they are crucial figures in the disciplining of the body. ${ }^{2}$ According to Sim, prison doctors have not simply benevolently healed prisoners but also helped to enforce the apparatus of physical and psychological control that surrounded them. This situation gains added intricacy in conflict zones, particularly when prison doctors feel obliged to support state objectives. They do things that clash with accepted medical ethical standards and which would seem unacceptable in times of peace. At worst, prison doctors associate themselves with torture. Force-feeding is often considered as one of these lapses in medical ethics.

In the years preceding Thomas Ashe's death, the suffragette movement had made considerable inroads in Ireland. ${ }^{3}$ The apparent imminence of Irish independence had produced opposing perspectives on whether Ireland should be autonomous from the UK. ${ }^{4}$ In response, two paramilitary forces came into existence prior to the outbreak of war: the Ulster Volunteers-formed to help maintain the Union with Britain-and the Irish Volunteers, a group co-founded by Thomas with the agenda of forcefully securing national independence. ${ }^{5}$ During the First World War, the constitutional path to Irish independence supported for some decades by the Irish Parliamentary Party was severely undermined by militant republicanism. ${ }^{6}$ In the 1910s, the Irish Republican Brotherhood (IRB) (later renamed as the Irish Republican Army or IRA) adopted a violent approach to securing independence and staged the Easter Rising in 1916.7 From the mid-1910s, republicans sought to undermine the legal and judicial systems established in Ireland by the British government. Hunger striking was central to their effort. ${ }^{8}$ Thomas Ashe was among the first known casualties of prison force-feeding. ${ }^{9}$ Like other hunger strikers, Thomas chose to self-mutilate and disfigure his own body by starving in a public spectacle of self-defacement. In an effort to restore digestion, prison doctors tackled the protest with their stomach tubes.

But what implications did the exigencies of conflict have for prison doctors dealing with hunger strikers? This chapter addresses this question 
using the case study of a doctor employed at Mountjoy Prison, Dublin: Raymond Granville Dowdall. By chance of being employed in a prison during a period of political tumult, Dowdall came face-to-face with an array of politicised prisoners, including suffragettes, labour leaders, and republicans. Many of these staged hunger strikes and were force-fed by Dowdall. Dowdall was forced to negotiate his precarious position as intermediate between the state and the fasting prisoners under his care. Yet Dowdall harboured negative attitudes towards politicised prisoners. Doctors do not always act neutrally; they share attitudes towards certain patients which can affect treatment. This is particularly the case at times of conflict when the willingness of prison doctors to adhere to medical ethical norms can be compromised by the specific socio-political context in which they work and reside. Unfavourable attitudes towards prisoners deemed 'terrorists' or 'dissidents' can encourage severe institutional treatment, especially if medical staff support government agendas. During civil conflicts, notions of the 'terrorist' shape doctor-patient interactions. Even physicians who normally adhere to the bioethical guidelines of their profession can experience serious ethical and psychological discord when dealing with individuals who have perpetrated violence, often against the members of their own communities. ${ }^{10}$ Anger and disdain might be felt by a doctor who believes that a 'terrorist' is undeserving of his or her assistance. At worst, (s)he might turn a blind eye to violence inflicted upon certain prisoners. ${ }^{11}$ At the time of writing, this problem is endemic at sites of incarceration including Guantánamo. Yet the problem is far from new. In the past, it encouraged a propensity to use force-feeding as a punitive, rather than therapeutic, mechanism.

Much depends on context. Force-feeding has been performed, experienced, and represented in contrasting, but deeply meaningful, ways. In the 1910s, different types of bodies were force-fed: male and female bodies; English and Irish bodies; wartime and peacetime bodies; suffragette and republican bodies. Different meanings came to be applied to the various types of force-fed bodies, depending on considerations such as gender and political identity. In the early 1910s, the Home Office sought to protect the weakened suffragette hunger striker from a self-imposed death, if only to avoid martyrdom. Her femininity played an important role. Yet prison doctors such as Dowdall performed force-feeding less carefully on male Irish republican bodies, a problem that resulted in death. Ultimately, Thomas Ashe's corpse came to be imbued with qualities of self-sacrifice and heroism in the face of an unrelenting government. As this chapter 
also suggests, Thomas's death had important professional implications for Dowdall and his colleagues who were called upon to provide evidence in a remarkably well-publicised and deeply contentious inquest. Their willingness to force-feed on behalf of the British state reverberated in revolutionary-period Ireland. As force-feeding crossed national boundaries, the procedure was no longer something done to recalcitrant, seemingly erratic, British women; it evolved into an act that symbolised the apparent threat posed by Britain to the sanctity of Ireland as a whole. Thomas's death held national meaning; his corpse illuminated the aggressiveness of the British government and its willingness to murder Irish men rather than grant them independence. In republican rhetoric, the stomach tube itself became a powerful political symbol; it transformed into a medical technology deeply imbued with political connotations. In using the stomach tube, Dowdall and his colleagues found themselves at the crossfire of this highly politicised scenario.

\section{Suffragette Force-Feedings in Ireland}

Dowdall pursued a career in prison medicine during a period of deep political tumult. At the start of the century, Dowdall was a well-respected public figure. Coroners regularly called upon him to provide evidence at inquests in Dublin. He was also a key Irish witness at the Royal Commission on the Care and Control of the Feeble-Minded between 1904 and 1906. ${ }^{12}$ Although little is known about his private life, census records reveal that Dowdall was a single Protestant who turned fifty in 1908 who lived with his housekeeper Catherine Gilbert. ${ }^{13}$ Prison medical services at Mountjoy were somewhat lacking. In the earlier stages of his career, Dowdall found himself at the centre of a number of controversies. In 1903, a female prisoner died at Mountjoy while serving a short fourteen-day sentence. Upon noticing her fading health, Dowdall consulted a second doctor who advised him that the prisoner's only hope of survival rested in a major operation for acute intestinal obstruction. The prison lacked the resources required to undertake this procedure. Although a jury later absolved Mountjoy's medical staff of blame for the prisoner's death, it highlighted a lack of medical facilities at the prison that might have saved her life had they been in place. ${ }^{14}$ Five years later, prisoner Richard O'Brien died suddenly of heart failure. The medical officer in charge, Dr Paisley, had announced midway through his shift that he was leaving the prison to attend the University Club in Stephen's Green. Paisley returned considerably later than expected 
with a strong smell of alcohol on his breath to learn that O'Brien had unexpectedly passed away. The prison staff incurred the wrath of Dowdall who, upon asking Mr Gamble, the prison clerk, 'why did you not telephone for me?', was informed that the Chairman of the Prisons Board did not recognise the use of the public telephone. ${ }^{15}$

As Ireland's socio-political climate changed, Dowdall began to encounter prisoners with strong political views. The Irish female suffrage movement formally emerged in 1876 when Quaker feminist, Anna Haslam, founded the Dublin Women's Suffrage Association, renamed the Irish Women's Suffrage and Local Government Association in 1911. Despite its modest beginnings, the Association attracted a significant number of new members in the opening decades of the twentieth century. ${ }^{16}$ Hanna Sheehy-Skeffington and Margaret Cousins founded the Irish Women's Franchise League in 1908. ${ }^{17}$ In summer 1912, Irish suffrage groups organised a number of peaceful protests which were overshadowed by the violence wrought by English WSPU members, Mary Leigh, Gladys Evans, and Lizzie Baker. The women not only threw a hatchet at Prime Minister Herbert Asquith and John Redmond, leader of the Irish Parliamentary Party but also tried to set fire to the Theatre Royal in Dublin. Lizzie Baker was convicted of conspiracy and given a sentence of seven months' hard labour. Mary Leigh and Gladys Evans were convicted of conspiracy, arson, and explosive charges and awarded five years' penal servitude, the lengthiest prison sentence given to a suffragette. ${ }^{18}$ As George Bernard Shaw pointed out in a letter published in the Irish Times, the severity and length of the sentencing rendered force-feeding problematic. Prisoners, he remarked, could not be kept alive with force-feeding for five years. Nor could they be released for such a serious crime. ${ }^{19}$ Yet the Home Office was determined to keep female hunger strikers alive to avoid martyrdom and circumvent public opinion turning firmly against its contested policies. ${ }^{20}$

At Mountjoy, the prisoners went on hunger strike and encountered Dowdall. The medical reports recorded by Dowdall during their feedings provide a rare portal into force-feeding from a doctor's perspective. They are challenging to interpret, but deepen and complicate propagandist suffragette claims of torture and abuse. They suggest that force-feeding was not always the haphazard, coercive process depicted by outraged suffragettes. Mary Leigh's medical report demonstrates that force-feeding could be a closely regulated, technological procedure that incorporated a range of diagnostic and observational medical techniques designed to monitor prisoner health, if only to avoid prison fatalities. It was not simply the case 
that doctors carelessly crammed a tube into the gullet of female patients, aiming to cause as much pain and discomfort as possible, despite suffragette claims. However, the high levels of care taken by Dowdall could be ascribed to political context. As William Murphy observes, hunger striking suffragettes serving sentences in Irish prisons tended to be treated more compassionately than their English counterparts. ${ }^{21}$ The high levels of media attention directed towards the prisoners cast Dowdall in the public spotlight. It is likely that he took particular care while feeding to avoid negative publicity or injury. Moreover, Dowdall was in close contact with Dublin Castle and the Home Office who received regular reports on the health of hunger striking suffragettes. He was under close observation.

How did Dowdall perform force-feeding? Prior to feeding Mary Leigh, Dowdall, Joseph O'Carroll of Richmond Hospital, and two prison medical officers carefully examined her for symptoms of organic disease. They measured her pulse, temperature, weight, and the gravity of her urine and its albumen and sugar content before deciding to 'artificially feed' her. Before commencing the procedure, the two medical officers loosely strapped Mary in a chair while preparing a funnel and soft rubber tube for her nasal feeding. They heated Mary's food-consisting of ten ounces of milk with one beaten up egg-to $98.4^{\circ} \mathrm{F}$ and fed her twice a day. Dowdall added medicines - bismuth and cascara - to his patient's food as required. On each occasion before administering food, he carefully examined Mary, meticulously recording her temperature, pulse, and weight.

Dowdall seemed to have approached (or at least recorded) his task as a medical procedure rather than a purely punitive one and paid close attention to his patient's health. Yet although Dowdall ostensibly sought to preserve his patient's health, he found that he could do little to stem the negative physical and emotional effects of force-feeding. A considerable degree of bodily manipulation was required for the procedure to run smoothly. Throughout her feeding, Dowdall failed to curb Mary's intense vomiting caused naturally by the rejection of the stomach tube and its contents by her body. To counter this relentless vomiting, Dowdall tried feeding Mary with foods of different temperatures. When this failed, he experimented with introducing food into the tube at various speeds. On one occasion, he kept his patient in the chair for an hour and fed her slowly under the hope that this might contain her vomiting. He then tried a slow feeding period lasting two hours, also to no avail. Dowdall's final step involved purchasing a special chair from Messrs Carter of London that allowed Mary to rest on her back after being fed. This also failed to stem Mary's vomiting. 
Dowdall's perception of his work appears to have been deeply informed by his gendered perspectives on the behaviour and mental health of militant women, as evidenced by the comments which he sketched on his patient's medical report. 'The act of evacuating the contents of the stomach', explained Dowdall, 'cannot in this woman's case properly be described as vomiting. The liquid food wells up in to the mouth and is expelled by her. It is more akin to the vomiting of hysteria'. This latter comment suggests that Dowdall subscribed to a popularly held perception of the suffragette as hysterical, excitable, and irrational, an idea commonly referred to when explaining her violent tendencies. ${ }^{22}$ As Rachael Russell notes, it was not uncommon for psychiatrists to interpret vomiting as a symptom of hysteria, as a product of the reflex action of the brain. Unlike normal vomiting, hysterical vomiting was sudden and unexpected. The stomach simply emptied itself. ${ }^{23}$ It is likely that Dowdall's perception of his patient as hysterical legitimated his view of the procedure as a medical necessity that needed to be enforced upon a mentally unstable patient whom he had a duty to care for. Casting his patient as hysterical also allowed Dowdall to divert blame for her body's adverse response to the feeding tube to the patient's poor mental health, not the feeding process. Dowdall also noted that Mary developed convulsive seizures while being fed. The first of these seemed to resemble tetanus; two subsequent seizures bore resemblance to the convulsions of hysteria. Arms flexed at the elbow, hands clenched, and both feet extended in a state of tonic spasm, Dowdall subjected Mary to a further five minutes of feeding. After he completed his task, Dowdall recorded: 'No appearance of pain caused by the nasal tube or any complaint of pain by the patient. No palpitation, irregularity of the heart, collapse, weakness or icy coldness of the extremities. No injury has been inflicted on the nasal passage or any bleeding. ${ }^{24}$

Interpreting this medical report presents problems. It is tempting to swiftly demonise Dowdall as a harsh, unfeeling, brutal individual who perhaps took great pleasure in the task newly assigned to him, following the lead of suffragette activists who routinely castigated prison doctors as torturers in their propaganda. ${ }^{25}$ Adopting a gendered perspective, Dowdall could be portrayed as a dominating male medical figure eager to subject his unfortunate female patient to an array of medical and technological procedures applied relentlessly even despite the obvious trauma, pain, and vomiting being caused by the procedure. There is also an experimental aspect to Mary Leigh's force-feeding; her body became an object that was restrained, observed, manipulated, and tested for its ability to withstand 
force-feeding. The emotions experienced by Mary during this handling of her body are left mostly unrecorded. However, can a certain extent of care-giving be detected in Dowdall's actions? One alternative reading would be that Dowdall took considerable care to measure his patient's health, temperature, and weight. He paid scrupulous attention to the amounts of food being inserted into the tube, its contents, and the speed in which it was inserted, and even obtained a chair from London to ease his patient's discomfort. Regardless of his motivations for keeping Mary healthy, she presumably interpreted her endless vomiting and the insertion of an intrusive tube into her body as emblematic of the state-sanctioned brutality which she found herself exposed to. Mary was eventually released from Mountjoy on licence following a consultation between President of the Royal College of Surgeons in Ireland, Thomas Myles, and renowned Mater Hospital physician Christopher Nixon. Prison doctors transferred Mary to the nearby Mater Hospital in a debilitated condition, too weak to stand up without help and in a state of collapse. ${ }^{26}$ In the following month, Gladys Evans was discharged in a similar condition. ${ }^{27}$ Force-feeding appears to have done little to improve or uphold bodily health, despite Dowdall's efforts to avert vomiting and pain.

\section{Republican Force-Feedings}

The value of having such a vivid account of Mary Leigh's experiences is that it allows for comparison with other politicised prisoners fed by Dowdall. In turn, evidence can be pieced together about the fraught relationships forged between Dowdall and the politicised prisoners whom he encountered. Dowdall seems to have acquired a taste for force-feeding. During the Dublin Lockout of 1913, he fed prisoners including Arthur Fagan who swiftly resumed eating and promised to behave. ${ }^{28}$ In 1913 , Dowdall force-fed labour leader, Frank Moss, for nine days followed by a lengthier period of eighteen days. ${ }^{29}$ Upon being released, Frank recalled to the Daily Herald that on one occasion Dowdall had lost his temper while experiencing difficulty inserting a nasal tube. Frank vividly described the sensation of Dowdall's failed attempts at insertion. He claimed that he 'seemed to feel something snap in his head' and that the agony continued when he was returned to his cell 'as if his brain was going'. 'I did not mind dying', he lamented, 'but I wanted to die sane'. ${ }^{30}$ Two years later, Dowdall announced his desire to feed prominent Irish pacifist, suffragist, and writer Frances Sheehy-Skeffington, although the Chief Secretary 
of Ireland, Augustine Birrell, directed against this, presumably due to Sheehy-Skeffington's high public profile. ${ }^{31}$ Evidently, Dowdall was firmly immersed in the political dramas of the day. As Mountjoy's chief medical officer, he came into contact with leading feminist, labour, and republican activists armed with his stomach and nasal tubes. He seemed undeterred by the intricate ethical discussion about the potential dangers of forcefeeding taking place in England and proved himself as a formidable opponent for many politicised prisoners who refused to eat.

It is difficult to determine whether Dowdall truly believed in his medical duty to save the lives of 'suicidal' prisoners or if he recognised the punitive value of feeding technologies in disciplining recalcitrant prisoners. What does seem clear is that Dowdall paid considerably less attention to the health and well-being of non-suffragette prisoners. Perhaps this was because the Home Office and Dublin Castle were less concerned about the health of republican prisoners than the suffragettes? Under less government scrutiny, Dowdall had free reign to perform the procedure as he wished. Or perhaps he felt more comfortable inflicting pain on a male body? Could it also be that Dowdall felt more invested in tackling Irish labour and republican prisoners? It is plausible that Dowdall had little interest in the cause of female suffrage, given that the movement was relatively less disruptive in Ireland. In contrast, republicanism posed a threat to the political and social structure of his nation. In the 1910s, it was presumably difficult not to hold an opinion on Irish independence. As a Protestant who had partaken in government Commissions, it seems likely that Dowdall felt at least some attachment to the existing political establishment that employed him. But did this worsen disciplinary conditions for the republican prisoners whom he fed?

Irish republicans began hunger striking following the Easter Rising. In 1917, forty prisoners were force-fed. ${ }^{32}$ Historian George MacSweeney presents republican hunger strike as an integral part of Irish history and mythology and argues that republicans including Thomas Ashe chose to refuse food in light of the influence of a national revival in traditional Gaelic cultural practices. ${ }^{33}$ However, it seems more conceivable that republican prisoners were cognisant of the recent efficacy of the suffragette hunger strikes in garnering public attention and sympathy. As Murphy suggests, suffragette hunger striking provided a template referred to by republicans during their campaign for independence. ${ }^{34}$ Irish republicans knew full well that force-feeding brought state policies into question and severely disrupted prison management. Nonetheless, war had now hardened the 
attitudes of state bodies and prison authorities to prison militancy and also towards republicanism, viewed from British and unionist standpoints as a betrayal to the more urgent cause of defeating German aggression..$^{35}$

The idea that Irish citizens were being fed against their will prompted an emotional public response rooted in sympathy for those imagined to be in physical and mental agony. Republican hunger striking was influenced by a vastly different set of gendered considerations than their suffragette equivalents. The issue of maltreating a female suffragette body had been deeply inflected by consideration of her femininity. Performing force-feeding on a female prisoner-deemed frailer and more physically vulnerable than her male counterpart-carried different connotations than subjecting a male prisoner to the same procedure. The Irish republican was stereotypically strong, muscular, and male, an image which Sikita Banerjee denotes as 'muscular nationalism'. ${ }^{36}$ In light of this, male republicans were presumed to be able to endure pain and discomfort, to withstand the procedure of force-feeding. Less therapeutic care was needed.

However, male republican prisoners also experienced force-feeding as an emotional and physical violation. Austin Stack, for instance, had been politically active since 1908 and joined the IRB in 1916 while acting as the commandment of the Kerry Brigade of the Irish Volunteers. In 1916, Austin was arrested and sentenced to death due to his involvement in the Easter Rising, although his sentence was commuted to penal servitude for life. He went on hunger strike in May 1917. Austin recorded his experiences of being fed in pencil on a sheet of poor quality paper (possibly toilet paper) which he intended to smuggle out of the prison to reach Thomas's sister Nora. Lamenting his encounter with the tube, Austin scrawled:

We resisted being carried to the operation room on Saturday evening when forcible-feeding began. Each of us was strapped arms and legs to a chair. I was fed on this occasion by Dr Cooke. It was very painful. My eyes watered during the whole time so that I could see nothing. I vomited during and after the process so that not one half of the food entered my stomach. My clothes were covered with the stuff. There was no attempt made to examine me or even to check my pulse before I was fed. On Sunday morning I was fed by Dr Dowdall. He was longer about the work and caused me even more pain than Dr Cooke. I said to him when he was trying to get the tube down my throat: 'the other doctor' (I did not then know Cooke's name) 'did not have half the difficulty'. Dowdall replied 'that may be' and went on with the work. ${ }^{37}$ 
Recollections made by other force-fed prisoners (contained in the Bureau of Military History oral history interview collection) further demonstrate that male prisoners experienced the procedure as a physical and mental assault upon their bodies, as a thoroughly degrading and brutal emotional experience. Eamon O'Dwyer later recounted that:

Each man in turn was brought to a large room in which they had the usual
operating chair. We were tied into this chair with bands around the legs and
arms, a band around the body and also a band around the neck, and into
each man's mouth an instrument was passed to keep it open. The forcible-
feeding outfit was brought along - a pint of milk with an egg broken into it,
the pump and the tubing. The tubing was passed down through the mouth
and into the stomach. I never had any fear of hunger striking and that was
the first one, but I certainly did not like this pipe being passed down through
my throat and I began to have a horror of it. I must admit that I was very
much afraid of it, and often in years afterwards I woke up and felt this damn
pipe or tube going down my neck like a snake. Every one of the crowd who
suffered this vomited terribly. The days passed with this [force-feeding] as
the only relief from the monotony of being held in the cell. . $^{38}$

For Eamon, force-feeding was not only highly uncomfortable but also left a lasting emotional and psychological impression. As the experiences of William Ball had demonstrated, male mental distress following forcefeeding was hardly unknown. Even despite recent evidence to the contrary, the mental stamina of male prisoners was expected to be robust, whereas the psychological instability of female prisoners was taken almost for granted. This indifference was also reflected in the relatively low levels of therapeutic attention awarded to male republicans by Dowdall and his colleagues in comparison to their female suffragette counterparts. Republican prisoners expressed deep concern over the limited attention being paid to their well-being. When scrawling his message to Nora Ashe on his prison paper, Austin Stack recorded that one of the male prisoners suffered from a weak heart. He advised his fellow prisoner to 'demand the attendance of an indifferent doctor', a clear reference to the sense felt by Austin that their treatment was being dictated, in part, by the conflicting political perspectives of doctors such as Dowdall and, perhaps, the objection of the medical staff to the upheaval created by events such as the Easter Rising of 1916 which Thomas Ashe and Austin Stack had both been involved in. ${ }^{39}$ 
It is important to note that this hostility and indifference towards republican prisoners was not endemic among all of the prison staff, a scenario that illuminates the complex relationships formed between prisoners and staff. Patrick J. Berry had joined the prison service as a warder in 1906 and became friendly with Thomas Ashe during 1917. He appears to have been sympathetic to the prisoners and their cause given that he later joined the IRB. Berry later recalled:

On the Sunday morning when they were bringing him down to the surgery room to administer the forcible-feeding by Dr Dowdall, it was I who took him down and I told him to give the doctor a bit of his mind. When he went in, the doctor asked him to take his food voluntarily. Ashe replied "no". Then the doctor said "If not I have no other alternative but to feed you forcibly". Thomas Ashe then said to the doctor [that] he would go down to posterity crowned with the blood of innocent Irishmen on his soul. He fed him through the mouth then and after that Ashe walked back to his cell. ${ }^{40}$

A shift in the behaviour of the medical staff occurred midway through the 1917 hunger strikes. Dowdall passed responsibility for feeding to $\mathrm{Dr}$ Lowe, a local physician who Patrick later denounced as 'a man who knew nothing about forcible-feeding'. This decision was made after Cooke failed to arrive at work after receiving a warning to not go near the prison. ${ }^{41}$ Prison doctors working in times of civil conflict often find their lives at risk, particularly if members of the public view them as complicit in torture or harsh punitive regimes. This was certainly the case in 1917 when doctors who force-fed could be viewed as akin to torturers. Although this death threat was presumably intended to ameliorate the situation of the prisoners by discouraging further feedings, it inadvertently led to a less experienced doctor being called in to undertake a procedure normally performed with greater care by the experienced Dowdall and Cooke. As Austin Stack wrote:

I was fed that morning by a strange young doctor, whose name I subsequently learned was Lowe... The doctor did not examine me in any way, but he felt my pulse. This was the first time any of the doctors had done even this with me. So far as I recollect he did not ask me any questions. He tried to put the tube down my throat for a long time and caused me very much pain. The hospital orderly kept my mouth open with a spoon lest I might take off the fellow's finger which he was putting down my throat for part of the time so that I felt almost strangled. After he had put down the tube 
a little way or the whole-I could not tell which-twice or three times, he took it out again.

The second or third occasion I vomited some stuff and thought the operation was over until he came to renew the efforts. I said, "I thought it was all over. The other doctors had not anything like this difficulty in feeding me". "Dr Cooke", I added, "is able to get down the tube without half the trouble". "Which side does he put it down?" asked Lowe. "Straight down my throat", I told him. He then went to work again and I suffered indescribable pain while he fiddled with his finger and with the tube to get the tube down my throat. Eventually, the thing was at an end and I vomited about half of what had been pumped into me. The reason why I could not say whether I was fed or not after his earlier effort was due to the pain I lost my senses for the moment. I was unable to see anything on account of water running from my eyes. ${ }^{42}$

If Austin's account can be taken at face value, the prison medical staff had brought in a relatively inexperienced doctor to undertake a procedure which required care and technical skill. The doctor caused levels of physical agony which Austin struggled to translate into words. Lowe persevered with force-feeding despite the severity of Austin's physical and emotional distress.

\section{Thomas Ashe's Inquest}

It seems clear that republican prisoners experienced a similar range of emotions to their suffragette counterparts while being fed by Dowdall and his colleagues. They felt fear towards the stomach tube, apprehension about its insertion into their bodies, and distress at the pain caused as liquid food poured through their digestive tracts. Yet they experienced a stronger sense that force-feeding was not being used solely for medical purposes. If anything, republican prisoners felt disdain at the lack of medical attention provided by Dowdall, contrasting sharply with the close levels of medical superintendence awarded to Mary Leigh. Indeed, republicans experienced force-feeding as part of a broader regime of punishment and discipline enacted upon their bodies. This feeling strengthened when Lowe fatally fed Thomas Ashe. The potential dangers of force-feeding were now irrefutably clear; Lowe's inexperience and carelessness had caused a death, bringing Mountoy's medical staff into public disrepute.

Dowdall now found himself allegedly complicit in a broader political agenda of subjugating Irish rebellion. Rather than having acted 
autonomously as part of the medical profession, he was now decisively cast as a doctor who had willingly abandoned the long-established medical ethical norms of his profession to force-feed. For a number of years, doctors who force-fed prisoners had clung to their argument that they had a duty to provide medical treatment when lives seemed endangered. Yet the boundaries between force-feeding as therapy or torture swiftly closed once Thomas's death made clear that the procedure could kill, if performed haphazardly. In this context, Dowdall's feedings came to be viewed as part of a broader discriminatory prison regime supported by the state that supported disciplinary techniques marred by violence and brutality.

Thomas Ashe's death prompted a passionate public response (buttressed by republican cries of murder) which transformed the prison fatality into a national tragedy in which all 'true' Irish citizens were expected to emotionally engage. National and local newspapers reported daily on the controversial inquest proceedings that followed Thomas's death. The inquest was a public display of anger, sentiment, and grief in which far broader debates about British presence in Ireland were played out. Republicans used the inquest to galvanise public feeling against British rule. ${ }^{43}$ To ensure that the public remained aware of its outcomes, the proceedings were published in pamphlet format. The result was a significant historical text that provides a unique insight into early twentieth-century Irish medical ethics and prison medical practice, albeit one which British authorities sought to destroy as many copies of as possible. ${ }^{44}$

In its preface, the pamphlet's editor asserted that Thomas's death was 'a graphic example of British government and Irish officialism in their operation'. 'A Government instinctively alive to its own interests and to the interests that it is supposed to represent in Ireland would have averted the disaster' explained the author, adding that 'apologists describe it as a "regrettable accident" but it was one of those accidents that was inevitable under the system of government that exists in Ireland'. As the author elaborated, 'the treatment of Thomas Ashe reveals a carelessness of consequences and a worship of the iron regulation which in themselves must make the detailed administration of Irish government a ceaseless and hopeless provocation of popular antagonism. ${ }^{45}$ Evidently, Thomas's death provided a suitable trope for casting wider judgement on the nature of British rule in Ireland in a period of burgeoning national political and social turmoil. ${ }^{46}$ Indeed, the inquest essentially served as a forum at which broader tensions between nationalist and unionist communities were rehearsed. The editor portrayed force-feeding as emblematic of the 
inhumanity inherent in British governance and as further justification for the need for political independence, a step that firmly implicated Mountjoy's medical staff.

The inquest continued a conversation initiated by the suffragettes in 1909 on technical matters relating to the safety of force-feeding and the extent to which the procedure fitted with contemporary medical ethics. Yet unlike the formal proceedings of Leigh v Gladstone in 1909, opponents of the practice now had the evidence of death on their side. Moreover, the harsher treatment meted out to Irish republican prisoners (due, in part, to institutional violence enacted upon men being less controversial than on women) ensured that a weightier catalogue of violence and intimidation was available as damning supporting evidence. Moreover, the idea that the British establishment supported a prison network so intent on disciplining that it willingly resorted to torture and intimidation (including forcefeeding) imbued the inquest with deep political resonance. The state, it seemed, was quite happy to use its prison staff as puppets to maim and kill its political opponents. The stomach tube was now firmly embroiled in a centuries-old debate on British rule.

At the inquest, Timothy Healy acted as counsel for Thomas's family. As an MP for the Irish Parliamentary Party, Healy had firm republican credentials. Healy single-handedly transformed the inquest into an arraignment of British rule. ${ }^{47}$ Like many English critics of force-feeding, he sought to establish the procedure as dangerous and incompatible with normal medical ethical practice. However, Healy went further. He claimed that force-feeding amounted to torture, seemingly exposing the human cost of Britain's incursion into Ireland, casting Dowdall as a puppet in a far broader political game. Ulster Unionist Henry Hanna represented the Crown and unsuccessfully tried to ensure that witnesses at the inquest discussed only the immediate cause of Thomas's death, not its broader political implications. ${ }^{48}$

The inquest was politically and emotionally charged. Healy commenced by calling upon John Irwin to provide evidence. Irwin had served as Chairman of the Visiting Committee of Prisons when Mary Leigh had been force-fed. During the republican feedings, he had visited the prison with medical doctor Kathleen Lynn and Thomas Myles to warn staff about the potential dangers of force-feeding. Irwin had personally witnessed the physical and emotional effects of force-feeding in asylum practice and during the suffragette hunger strikes. Healy's questioning revealed harrowing issues about Thomas's death. It transpired that Thomas's bed and 
bed-clothing had been removed on the two nights immediately preceding his feeding, a punishment that had prompted Irwin and the Lord Mayor of Dublin to head to Dublin Castle to remonstrate. ${ }^{49}$ Thomas's body had not only been force-fed but also subjected to a range of physical and mental punishments that had lowered his physical and mental stamina. This supporting evidence indicated that, in this instance, force-feeding formed part of a far broader disciplinary regime for Mountjoy's politicised prisoners. In turn, this raised the problematic question of why Dowdall had authorised force-feeding on an already debilitated individual.

Professor Edmund Joseph M'Weeney, pathologist at National University Dublin and the Mater Hospital, provided further disquieting evidence. M'Weeney had been tasked with examining Thomas's corpse. At the inquest, he described the corpse as muscular and well-developed with few signs of emaciation. He recounted having seen superficial scratches around Thomas's jaw, nine superficial excoriations on his chin, scratches on his lips, and number of small excoriations visible around his Adam's apple. M'Weeney reported that a depression 'not unlike the mark of a thumb nail' had been perceptible below Thomas's thyroid cartilage. M'Weeney concluded that Thomas's death had resulted partly from syncope owing to the failure of a weak and slightly dilated heart and partly from passive congestion and oedema of both lungs. ${ }^{50}$ The violence enacted upon Thomas by Dowdall, Cooke, and Lowe had been rendered visible; force-feeding had left physical scars in addition to the emotional scars reported by prisoners including Austin Stack. Thomas seemed to have been 'force'-fed rather than 'artificially' fed.

But had the force-feeding actually killed Thomas? A protracted debate ensued about Thomas's heart, which M'Weeney noted to have been three ounces above the average weight of a male heart. Thomas, M'Weeney commented, was a man of excellent physique, if slightly fat. 'One would expect a large heart to go with a large physique,' he explained. When asked how long a well-nourished man with a fairly fat physique could withstand hunger, M'Weeney made clear his view that 'the deceased did not die of hunger' but instead from congestion of the lungs brought about by having been force-fed before his weak, dilated heart failed. 'I consider that a man of that type of heart', explained M'Weeney, 'would be very apt to succumb to any sudden shock or to any prolonged physical struggle which he might have to go through', adding that even if the prison medical staff had actually taken the time to examine Thomas's heart prior to feeding, it was unlikely that they would have detected its 
true state of health by auscultation. ${ }^{51}$ M'Weeney's views on the role of shock in increasing susceptibility to heart conditions corresponded with contemporary medical thought on the relationship between the emotions and heart conditions. Various esteemed physiologists (most notably William Osler, Clifford Allbutt, and William Sadler) ascribed sudden heart failure to mental stress and strain, to physical exertion coupled with mental stress. They understood heart conditions as simultaneously emotional and physical. ${ }^{52}$ In McWeeney's view, the mental and emotional shock which Thomas had been continually exposed to in prison had predisposed him to a sudden and fatal heart condition. The very fact that forcefeeding had broken down the body of a stout, muscular, and masculine male republican bore testimony to the apparent viciousness and danger of the practice when used on prisoners, something which critics across the British Isles had argued for almost a decade. Following McWeeney's evidence, Healy vehemently announced that the British state had managed to murder Thomas.

By this stage of the inquest, it seemed clear that Thomas had died from complications with the forceful insertion of a stomach tube. Hanna insisted that Thomas had not been force-fed but, on the contrary, had refused to feed himself. He also pointed out that the prison had been in a state of pandemonium due to the hunger strikes, stating that 'the whole prison system and Government could not be held up because these men refuse to take food for two days'.$^{53} \mathrm{He}$ then made the case that Dowdall, Cooke, and Lowe had simply tried to fulfil their medical ethical duties to sustain life in highly unusual and challenging circumstances. 'If these men [the prisoners], in times like these', asserted Hanna, 'endeavour to raise sedition and disaffection amongst his Majesty's subjects, they had no reason to complain that the law that they were up against-so long as it had power-must be enforced'. Hanna evoked the broader crisis of the First World War to further justify force-feeding. For him, the infliction of pain on recalcitrant prisoners to quell Irish rebellion was more than welcome at a time when Britain and Ireland were confronted with the far broader problem of international war. Yet Hanna's claim that the doctors had performed a safe, therapeutic procedure seemed unconvincing given the cuts and bruises evident on Thomas's body and the fatal damage done to his inner body. Healy persisted in disrupting Hanna's interpretation of prison events. 'I want the instrument that killed him', Healy demanded to Dr Lowe at one point, 'the instrument of death-I want to find out your experience as a "pumper". ${ }^{54}$ 
Under considerable pressure, Dowdall provided evidence and stood by his argument that he had been required to authorise 'artificial feeding' in line with his ethical and professional duty to sustain patient health. Nonetheless, he struggled to explain why he had decided to feed Thomas after two days of solitary confinement without a bed, bedding, or boots. ${ }^{55}$ Hanna then called in Dr Kinsella, prison medical officer at Maryborough Prison, who informed the inquest that he had once fed a prisoner artificially for nearly two years, adding that this individual had even gained weight in that time. In response, Healy furiously asked: 'Before you fed your patients artificially did you put them naked in a cell and deprive them of their bed, bedding, boots and clothes for fifty hours? ${ }^{56}$ Following a number of similar assertions, Hanna jumped to his feet, announced his objections to the repetition of words such as 'killed' and 'murdered', and stormed out of the inquest. ${ }^{57}$ Sensing the unfavourable direction in which the inquest was heading, Hanna spent the closing hours of the inquest taking steps to ensure that Lowe was not charged with negligence. In many ways, Lowe was fortunate. Even Austin Stack was forced to admit that the inexperienced physician had in fact been the only person who had taken the time to check his pulse before commencing force-feeding. ${ }^{58}$ Dowdall and Cooke's handing over of the task of force-feeding to Lowe absolved them of direct blame, although their re-assignment was negatively commented upon.

Until the end of the inquest, Hanna remained determined to convince the jury that Thomas would still be alive had he not commenced a hunger strike. In his view, Thomas had died from a condition brought about only by himself and due to a weak heart condition which he had the misfortune to have been born with. 'It would be unfair', Hanna concluded, 'to lay the blame of his death on the shoulders of any one man', a final attempt at absolving Lowe. ${ }^{59}$ Ultimately, the jury concurred that Thomas had died of heart failure and congestion of the lungs caused by having his bed and boots removed and then being force-fed. The jury also concluded that Thomas had only gone on hunger strike to protest against the cruel punishment being inflicted on a class of prisoner who deserved special category status. Importantly, they condemned force-feeding as inhumane and dangerous and recommended its discontinuance in Ireland. ${ }^{60}$ Evidently, the attitudes of the prison staff towards its republican prisoners had mitigated against appropriate medical treatment. Ultimately, Thomas has been subjected to a series of punishments and feedings without proper attention being paid to his health. The violence and emotional trauma suffered 
by Thomas was brought to light in his inquest and cast disparity on the practice of force-feeding. The strong emotions sparked by force-feeding guaranteed that Dowdall and his colleagues found themselves at the epicentre of a broader political debate, conducted at a time of deep political tension, about the nature of British rule. They were cast as agents of an aggressive state willing to kill its political opponents rather than provide humane institutional conditions and grant politicised prisoners special category status.

\section{Conclusion}

At times of conflict, the medical ethical behaviour of prison medical staff has often been compromised by over-riding socio-political demands. Due to their 'dual loyalty' to their profession and the needs of the state, prison doctors have often found themselves embroiled in broader political debates when working in spaces of civil conflict. By virtue of being employed in a prison at a time of escalating socio-political discord, Dowdall came into contact with a number of politicised prisoners. Wittingly or not, he played an important role in helping the state confront political dissidents who had decided to hunger strike. Prisoner experiences varied. Dowdall exhibited skill and care while force-feeding suffragette prisoners, supporting the government's desire to avoid martyrdom. However, Mountjoy's staff seem to have held less favourable views towards republican prisoners, particularly those on hunger strike. They responded to prison protests with harsh punishments and careless force-feeding. The attitudes of prison medical staff towards these hunger strikers were clearly mediated through considerations including gender, nationality, and political perspectives. Negative perceptions of republicans as 'terrorists' and 'dissidents' encouraged prison experiences marred by violence and brutality. Prisoners experienced fear, resentment, and psychological distress upon being fed with a stomach tube. Thomas Ashes's death still occupies an important place in the emotional landscape of Irish republicanism; at the time it became upheld as a national occasion for grieving. Dowdall's participation in tackling political dissidence ultimately cast him in negative light. As Mountjoy's chief medical officer, he played a somewhat prominent role in the Irish revolution. His feedings were nationally reported and he was ultimately forced to provide evidence at a highly publicised inquest.

Analysis of Dowdall's career trajectory demonstrates that doctors can become subject to an array of professional and personal problems when 
called upon to force-feed politicised prisoners. The strain of managing large groups of recalcitrant prisoners places pressure on prison medical practice and encourages lapses in medical ethics less likely to occur in peacetime. Medical practice is deeply embedded in socio-political contexts. This is particularly the case at times of conflict. Politicised prisoners tend to be armed with the propaganda machines of their particular movements. Moreover, a death from force-feeding-publicly perceived as a painful, degrading, and unnecessary assault upon the body-can elicit sympathy and compassion even among those who do not support the agendas of political dissidents. Force-feeding casts prison doctors as perpetrators of violence and torture in a western socio-cultural climate that mostly abhors the idea of pain being inflicted upon individuals who have already lost their liberty. Claims that force-feeding amounts to therapeutic treatment generally prove unconvincing, a problem with significant implications for those doctors who choose to force-feed.

\section{Notes}

1. S. O'Cathasaigh, The Story of Thomas Ashe (Dublin: Fergus O'Connor, 1917), p. 11.

2. J. Sim, Medical Power in Prisons: The Prison Medical Service in England 1774-1989 (Milton Keynes and Philadelphia: Open University Press, 1990).

3. For a classic account, see Rosemary C. Owens, Smashing Times: A History of the Irish Women's Suffragette Movement, 1889-1922 (Dublin: Attic Press, 1984).

4. For an insightful overview of the various forms of nationalism present in early twentieth-century Ireland, see Thomas Hennessey, Dividing Ireland: World War One and Partition (London and New York: Routledge, 1998), pp. xi-xxi. For Unionism, see Paul Bew, Ideology and the Irish Question: Ulster Unionism and Irish Nationalism, 1912-16 (Oxford: Clarendon Press, 1994).

5. For the Ulster Volunteer Force, see T. Bowman, Carson's Army: The Ulster Volunteer Force, 1910-22 (Manchester: Manchester University Press, 2012). A standard text on the Irish Volunteers is F.X. Martin, The Irish Volunteers 1913-15: Recollections and Documents (Dublin: James Duffey, 1963).

6. See Michael Laffan, The Resurrection of Ireland: The Sinn Féin Party, 19161923 (Cambridge: Cambridge University Press, 1999).

7. Owen McGee, The IRB: The Irish Republican Brotherhood from the Land League to Sinn Féin (Dublin: Four Courts Press, 2007). 
8. Murphy, Political Imprisonment and the Irish.

9. Casualties had been reported in asylums. In 1912, suffragette newspaper, the Irish Citizen, reported on the inquest of a lunatic, James McGavigan, who had died at Letterkenny Lunatic Asylum, Co. Donegal, half an hour after being force-fed. McGavigan's stated cause of death was heart failure, an outcome used by the Irish Citizen to remind its readers 'of what this process really means and what it may involve'. See 'Forcible Feeding: Death of a Patient in an Irish Asylum', Irish Citizen (14 December 1912), p. 247.

10. Benjamin Gesundheit, Nachman Ash, Shraga Blazer and Avraham I. Rivkind, 'Medical Care for Terrorists: To Treat or not to Treat?', American Journal of Bioethics, 9:10 (2009), pp. 40-2.

11. For recent debate, see Jonathan H. Marks, 'The Terrorist and the Doctor: A Legal and Ethical Response', American Journal of Bioethics, 9:10 (2009), pp. 49-51; Michel Davis, 'Terrorists are Just Patients', American Journal of Bioethics, 9:10 (2009), pp. 56-7.

12. Minutes of Evidence of the Royal Commission on the Care and Control of the Feeble-Minded Volume III, Commons, Reports of Commissioners, 1908 [Cd. 4215], p. ix.

13. www.census.nationalarchives.ie/pages/1911/Dublin/Inn_s_Quay/ Mountjoy_Prison/18165. Accessed 15 May 2013, 11.32am.

14. British Journal of Nursing, 31 (19 September 1903), pp. 231-2.

15. 'Death at Mountjoy Prison', Irish Times (26 October 1908), p. 11.

16. Rosemary Cullen Owens, Smashing Times: A History of the Irish Women's Suffrage Movement, 1889-1922 (Dublin: Attic Press, 1984), pp. 24-5.

17. Owens, Smashing Times, pp. 41-2.

18. William Murphy, 'Suffragettes and the Transformation of Political Imprisonment in Ireland, 1912-1914', in Louise Ryan and Margaret Ward (eds), Irish Women and the Vote (Dublin: Irish Academic Press, 2007), pp. 114-35 on p. 129.

19. 'Dublin Suffragist Prisoners: Letter from Mr Bernard Shaw', Irish Times (17 September 1912), p. 7.

20. Miller, 'A Prostitution of the Profession', p. 229.

21. Murphy, 'Suffragettes and the Transformation of Political Imprisonment', p. 117.

22. Elaine Showalter, The Female Malady: Women, Madness and English Culture, 1830-1980 (London: Virago, 1987), pp. 162-4; Vernon, Hunger, p. 67.

23. Rachael Russell, 'Nausea and Vomiting: a History of Signs, Symptoms and Sickness in Nineteenth-Century Britain', Unpublished PhD thesis, University of Manchester, 2012, pp. 79-81.

24. National Archives of Ireland (hereafter NAI), GPB/SFRG/1/42, 'R. G. Dowdall, Medical Report', Autumn 1913. 
25. Showalter, Female Malady, pp. 162-4; Miller, 'A Prostitution of the Profession', pp. 236-40.

26. 'Suffragist Prisoner Released: Mrs Leigh taken to a Nursing Home', Irish Times (21 September 1912), p. 8.

27. 'Release of Miss Gladys Evans: Victory of Hunger Strikers', Irish Times (12 October 1912), p. 6.

28. NAI, GPB/SFRG/1/42, 'Newspaper Clippings', Freeman's Journal, 11 October 1913.

29. NAI, GPB/SFRG/1/18, 'List of Prisoners on Hunger Strike'.

30. NAI, GPB $/ 1 / 24$, 'Letter from Raymond G. Dowdall to General Prisons Board', 26 October 1913; 'Strapped to Torture Chair: Brutal Warders Recruited from the Hibernians; The Sufferings of Frank Moss', Daily Herald (26 February 1914), p. 2.

31. NAI, GPB/1915/3088.

32. Flynn, Pawns in the Game, p. 4.

33. George Sweeney, 'Irish Hunger Strikes and the Cult of Self-Sacrifice', Journal of Contemporary History, 28:3 (July 1993), pp. 421-37.

34. Murphy, 'Suffragettes and the Transformation of Political Imprisonment', p. 129.

35. Keith Jeffrey has noted that martial law was imposed during the Easter Rising primarily due to the circumstances of war. See Keith Jeffrey, Ireland and the Great War (Cambridge: Cambridge University Press, 2000), pp. 52-3.

36. Sikita Banerjee, Muscular Nationalism: Gender, Violence and Empire in India and Ireland, 1914-2004 (New York and London: New York University Press, 2012), pp. 45-57.

37. National Library of Ireland (hereafter NLI), MS44.612, 'Account of the Forcible Feeding at Mountjoy Prison resulting in the Death of Thomas Ashe', 20-25 September 1917, pp. 7-9.

38. Bureau of Military History (hereafter BMH), Witness Statement 1474, Eamon O'Dwyer, pp. 14-15.

39. Ibid., p. 12.

40. BMH, Witness Statement 942, Patrick J. Berry, p. 4.

41. Ibid., p. 5.

42. 'Account of Hunger Strike', pp. 19-23.

43. Ben Novick, Conceiving Revolution: Irish Nationalist Propaganda during the First World War (Dublin: Four Courts Press, 2001), p. 239.

44. Thomas Ashe, The Death of Thomas Ashe: Full Report of the Inquest (Dublin: J. M. Butler, 1917).

45. Ibid., p. viii.

46. Novick, Conceiving Revolution, pp. 236-9.

47. Frank Callanan, T. M. Healy (Cork: Cork University Press, 1996), p. 529. 
48. For a detailed account of the inquest, see Flynn, Pawns in the Game, pp. 27-38.

49. Ashe, Death of Thomas Ashe, pp. 4-5.

50. Ibid., p. 6.

51. Ibid., p. 7.

52. Fay Bound Alberti, Matters of the Heart: History, Medicine and Emotion (Oxford: Oxford University Press, 2010), pp. 153-6; Mark Jackson, The Age of Stress: Science and the Search for Stability (Oxford: Oxford University Press, 2013), p. 59.

53. Ashe, Death of Thomas Ashe, p. 15.

54. Ibid., p. 17.

55. Ibid., pp. 24-5.

56. Ibid., p. 28.

57. Ibid., p. 41.

58. Ibid., p. 80 .

59. Ibid., p. 82 .

60. Ibid., p. 93.

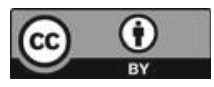

This chapter is distributed under the terms of the Creative Commons Attribution 4.0 International License (http://creativecommons.org/ licenses/by/4.0/), which permits use, duplication, adaptation, distribution and reproduction in any medium or format, as long as you give appropriate credit to the original author(s) and the source, provide a link to the Creative Commons license and indicate if changes were made.

The images or other third party material in this chapter are included in the work's Creative Commons license, unless indicated otherwise in the credit line; if such material is not included in the work's Creative Commons license and the respective action is not permitted by statutory regulation, users will need to obtain permission from the license holder to duplicate, adapt or reproduce the material. 


\section{'A Few Deaths from Hunger Is Nothing': Experiencing Starvation in Irish Prisons, $1917-23$}

What does it feel like to be on hunger strike? What actually happens, physically and emotionally, to fasting prisoners? And how do doctors interact with hunger strikers when they are not allowed to force-feed? In many ways, the problems created by allowing prisoners to starve are similar to those posed in euthanasia debates. These centre on whether physicians should withhold treatment to let a patient die if requested, an act normally seen as ethically preferable to actively killing a patient. ${ }^{1}$ In such circumstances, physicians tend to value the principle of patient autonomy but consider their options in light of ethical and legal considerations. ${ }^{2}$ However, hunger striking presents a slightly different quandary. Hunger strikers do not normally wish to die, although they are willing to do so if absolutely necessary. Also, unlike euthanasia patients, their intention to die usually stems from political agendas, not from any desire to escape from pain or suffering through death. Dying in no way benefits a hunger striker, although it can certainly aid his or her broader political cause. To further complicate matters, prison doctors are normally dealing with patients in the prime of their lives who would be perfectly healthy if they simply resumed eating. Unlike euthanasia, hunger strikers inflict pain and suffering upon their healthy bodies and refuse medical intervention; they manipulate and damage their own bodies for a broader political purpose.

Using the case study of revolutionary-period Ireland, this chapter examines prisoner experiences of fasting. Using autobiographical evidence, it recaptures historical experiences of hunger striking to illuminate 
the physical and emotional consequences of hunger striking, the means of coping developed by prisoners, and the structuring of prison medical encounters. Relatively little is known about what happens to the human body without food. It would be somewhat unethical to starve a healthy human being for research purposes. Moreover, politicised hunger strikers are rarely, if ever, willing to be monitored for experimental purposes. ${ }^{3}$ The scientific writing that exists on what happens to the starving human body tends to be highly technical; it fails to communicate the human suffering involved in the spectacle of starving oneself. Yet it is this physical and mental anguish that captures the attention of a sympathetic public. Hunger striking is an intensely personal act involving a body in distress. Yet the suffering body also has immense rhetorical potential. Bodily pain might be experienced privately behind the enclosed walls of the prison, but it reaches out to a public sphere that shares particular discourses on civility, compassion, and the need to avoid senseless deaths. ${ }^{4}$

Between 1917 and 1923, group hunger strikes were allowed to run their course for the first time, occasionally to death. After 1917, Irish prison doctors could no longer cling to their argument that they had an ethical duty to force-feed fasting prisoners. The procedure had become far too associated with violence, torture, and brutality. But perhaps many doctors genuinely saw force-feeding as a lesser evil than watching patients inflict a slow, agonising death upon themselves. Exacting pain with a stomach tube certainly clashed with the medical ethical norms of the day. But allowing prisoners to die without intervening was equally problematic in a socio-cultural context that placed high value on the sanctity of life. Today, doctors in most countries are obliged to maintain distance from hunger strikers - to observe, but not halt, their gradual disfigurement and deterioration. They cannot hinder a slow descent into death as the personal autonomy of hunger strikers is now respected. When faced with a hunger striker, doctors are advised to establish trust, inquire into whether the protest will be short or until death, and determine whether the prisoner will allow physical examinations, weight measurements, daily visits, and hospitalisation. ${ }^{5}$ Doctors also ensure that hunger strikers understand the likely consequences of refusing food. As mental deterioration (accompanied by a loss of competence) occurs in the later stages of a hunger strike, physicians are advised to obtain a living will type advance directive that would guide them in conforming to the patient's wishes if starvation progressed to coma stage. ${ }^{6}$ Force-feeding is only permissible when a hunger striker seems incapable of forming a rational judgement (although 
American courts have regularly failed to support the right of a rational prisoner to choose to starve).

To shed light on such issues, this chapter examines the transition away from force-feeding policies in Ireland following Thomas Ashe's death in 1917. Historians of the Irish revolutionary period have mostly focused on the small number of hunger strikes that actually ended in death (most notably that of Terence MacSwiney) at the expense of numerous non-fatal protests. ${ }^{7}$ Yet between 1917 and 1923, thousands of hunger strikes took place in Ireland. William Murphy has provided a broader narrative which details many of these protests. ${ }^{8}$ But deeper analysis of doctor-patient relations and the decaying hunger striking body itself could offer insight into the broader issue of how doctors and patients in conflict areas interact and cope with the physical and mental strain of hunger striking. Unlike forcefeeding, self-starvation is something done to one's own body; it raises few claims of unwarranted assault and bodily violation. In the late 1910s, this radically altered doctor-patient relationships. In fact, tensions eased considerably between Irish doctors and hunger strikers. Many doctors felt compassion and sympathy towards their fasting patients. In light of this, prisoners began to experience hunger striking differently. They felt pain, discomfort, and hallucinations as hunger took its natural course. Some prisoners progressed to coma stage as their bodies finished depleting natural fat reserve supplies. Although traumatised, hunger strikers enjoyed more positive interactions with their doctors than had been the case when the government supported force-feeding. Once the personal autonomy of a patient began to be respected, something closer to a normal medical encounter occurred. Nonetheless, the extent of bodily harm inflicted during a hunger strike can help to explain why some doctors might consider force-feeding as ethically preferable to allowing prisoners to starve themselves to death.

\section{Changing Relations}

From 1917, new relationships were forged around hunger striking prisoners. Prison doctors fashioned new identities as helpless overseers of death; prisoners transformed from torture victims to political martyrs; hunger striking evolved from a last resort of the seemingly irrational to a form of spiritual sacrifice. Thomas's death made clear, even to advocates of 'artificial feeding', that the procedure was potentially dangerous, life-threatening, and incompatible with standard therapeutic care. Although the 
government never formally conceded that force-feeding could be unsafe, even despite a prominent prison fatality, its enthusiasm for resorting to the stomach tube in Ireland swiftly waned. There, force-feeding was now highly contentious.

Thomas's death occurred during a period of strain in Anglo-Irish relations caused by the controversial execution of the leaders of the 1916 Easter Rising, delays in implementing Home Rule (postponed indefinitely until after the First World War), antagonism towards plans to impose wartime conscription in Ireland, and vexed debates on the idea of partitioning Ireland to appease Ulster Unionists in the north of the country who remained loyal to the British state. ${ }^{9}$ This turbulent backdrop ensured that what could have been an isolated prison incident transformed into a national scandal. Republicans harnessed Ashe's death as emblematic of British brutality. In the turbulent years that followed the First World War, Irish prisoners went on hunger strike with remarkable alacrity. From 1918, political and social tensions between England and Ireland intensified. In the general election of that year, republican political party Sinn Féin gained 73 seats in Ireland out of a total of 105, although Unionists retained a majority in the northern province of Ulster. Sinn Féin members refused to take their seats in the House of Commons and pledged to set up an autonomous Irish parliament. The First Dáil government (legally unrecognised by the British government) met for the first time in January 1919 at Mansion House, Dublin, and declared that England and Ireland were at war. ${ }^{10}$ The Irish War of Independence followed, a period of national violence in which the IRA, the army of the self-proclaimed Irish Republic, fought a protracted guerrilla war against the British government and its forces in Ireland. ${ }^{11}$ The autonomous Irish Free State was established in 1922, although conflict ensued between two opposing republican groups over the contested terms of the Anglo-Irish Treaty which left six counties in the north of Ireland within the UK. Contestation over this matter resulted in the Irish Civil War (1922-23), a violent conflict between proand anti-Treaty factions of the republican movement. ${ }^{12}$

The extent of hunger striking during these conflicts placed tremendous pressure on the Irish prison service. Michael Biggs has estimated that between 1916 and 1923, prisoners and internees staged approximately 10,000 hunger strikes. The vast majority gained concessions. Many were released. This severely undermined policies of imprisonment and internment and demoralised the police and military forces who wondered why they were bothering to arrest republicans only to see them prematurely 
released while on hunger strike. ${ }^{13}$ The numbers of republican prisoners willing to hunger strike en masse took a mental toll on prison medical staff. In 1916, a doctor at Frongoch internment camp, Merionethshire, Wales, threw himself into a quarry reportedly due to the mental stress of dealing with up to 200 fasting Irish prisoners. ${ }^{14}$ In the House of Commons, nationalist politician, Laurence Ginnell, insinuated to the Home Secretary that this doctor had committed suicide after being forced to perform an 'act of cruelty', a tacit reference to force-feeding. ${ }^{15}$ During the War of Independence, hunger strikes formed part of a broader republican strategy of undermining the British administrative system (also reflected in the targeting of Royal Irish Constabulary officers). As republican publicity officer, Frank Gallagher, asserted, 'by smashing the prison system we become free to continue the smashing in Ireland of their Empire ... a few days' hunger in payment for such a blow is nothing... even a few deaths from hunger is nothing. ${ }^{16}$ For such reasons, thousands of prisoners staged hunger strikes. During the subsequent Civil War, anti-Treaty Republicans went on hunger strike to protest against the mass imprisonment of prisoners who felt betrayed by the creation of an independent state without the six northern counties. ${ }^{17}$ In October 1923 (five months after the conflict had formally ended), around 7800 anti-Treaty republicans initiated a mass hunger strike. ${ }^{18}$

During this period of intense socio-political tumult, it became evident that policies of allowing self-starvation harboured their own set of ethical problems. Starving prisoners suffered from a spectrum of physical, psychological, and emotional conditions, but mostly refused therapeutic care. How did prison doctors transition from being perpetrators of forcefeeding to carers of the starving? As early as 1912, George Bernard Shaw had recognised the precariousness of allowing prisoners to starve. In a letter published in the Irish Times, Shaw had commented that 'as long as the Government placed within the prisoner's reach a sufficiency of food, I do not see how it could be held responsible for the prisoner's death'. Nonetheless, Shaw fully appreciated the emotional complexity of hunger striking and the degree of public feeling likely to emerge should a prison death occur, even if staff had provided food. The government could still be held responsible if seen as having created or supported the conditions that encouraged prison protest or as having obstinately failed to concede to reasonable demands. Shaw perceptively added that if 'the suffragists in Mountjoy are allowed to kill themselves, the sorrow which such an event will create, in spite of all logic, will be inspired by the Government and 
not by the victims. And that is the final weakness of the position of the Government'. ${ }^{19}$ For Shaw, the emotional consequences of a prisoner starving to death would always outweigh the logical, but less impassioned, argument that death was something a hunger striker had brought upon him/ herself. Shaw also alluded to the problem of prematurely releasing prisoners committed for serious crimes (in this instance, arson). As he observed, 'to release a really dangerous criminal after a fortnight's stomach pumping would be ridiculous. ${ }^{20}$ The inherent dilemma for the government was that concessions (such as early release) or prison deaths were both negative outcomes. Moreover, the government also feared that if it yielded to hunger strikers, then further politicised prisoners would go on hunger strike, as well as convict prisoners. ${ }^{21}$ But a prison death would only strengthen public perceptions of the sacrificial (rather than suicidal) hunger striker, bolstering public support for the prisoners and their broader cause. ${ }^{22}$

How, then, did policies change? By 1917, force-feeding was widely agreed upon in Ireland as hazardous, whether performed on men or women. The fact that a stout, strong male body had succumbed to the effects of the procedure strengthened the case against force-feeding. Irish newspapers emphasised Thomas Ashe's strength and brute masculinity to demonstrate antipathy towards the procedure. The King's Co. Independent reported his death under the heading 'he was of magnificent physique', adding that 'he was generally spoken of as the man who would be able to hold out longest and bear the hardship and its ill effects'. ${ }^{23}$ The stomach tube was no longer simply a weapon used against physically and emotionally frail female prisoners. It was now portrayed as a potent weapon that could subjugate- even murder-muscular Irish prisoners.

Meanwhile at Mountjoy, prison staff had to decide what to do with those prisoners still on hunger strike in the tense days that followed Ashe's death. At the end of September, a Board assembled at the prison to find a solution. It concluded that 'artificial feeding' did little to uphold the health of prisoners after all. Accordingly, the Board recommended the conditional release of thirty-nine prisoners including Austin Stack. ${ }^{24}$ In November, Dublin Castle instructed Irish prison governors that prisoners should only be force-fed by special order and should recommend temporary discharge under the Cat and Mouse Act if physical collapse seemed imminent. A further memorandum dispatched to Irish prisons in November from the Under-Secretary for Ireland, William Byrne, instructed that 'any prisoner, whose condition in the opinion of the medical officer requires it, should immediately be released without waiting for further authority'. ${ }^{25}$ 
Force-feeding was by no means ruled out. Yet, in Ireland, the tide had turned firmly against the procedure. Doctors who force-fed found themselves subject to strong public censure. In January 1918, Mountjoy's medical staff force-fed Sinn Féin prisoners, James Roche and Edward Horan, raising protests from Count Plunkett and Irish MP (and future president of Ireland) Seán T. O'Kelly. ${ }^{26}$ They fed Edward for nine days and James for ten before recommending temporary release. ${ }^{27}$ Dowdall, O'Carroll, and Cooke refused to continue 'artificial feeding' for any longer unless a Commission or Committee represented by expert medical opinion endorsed such a decision. ${ }^{28}$ Given Dowdall's fervour for feeding politicised prisoners, this was unexpected. He presumably felt little concern about James and Edward's welfare. However, he was reluctant to be placed once again in a legal scenario where he might be forced to assume responsibility for death or injury. Dowdall was now feeding prisoners in the face of high public sensitivities. Upon being released, eighteen-year-old Edward complained to an Irish Independent journalist that he had vomited blood while being fed. ${ }^{29}$ Dowdall wrote privately to the General Prisons Board stating that he had stopped feeding upon noticing this blood and that Roche's gum complaints had been self-inflicted. ${ }^{30}$ Nonetheless, the sight of blood seemed to have finally encouraged Dowdall to put down his stomach tube once and for all.

During the War of Independence, force-feeding was performed occasionally, but strong public feeling ultimately deterred prison doctors. When doctors at Limerick Prison force-fed a number of prisoners in February 1919, public anger mounted. ${ }^{31}$ Two months later, the Limerick Board of Guardians refused to appoint Dr McGrath as a dispensary medical officer due to his involvement in these feedings, even though McGrath had temporarily held the post for the past three years. ${ }^{32}$ In 1920, the unexpected removal of three prisoners from Cork Prison stirred excitement when a Cork Examiner journalist reported that the men, close to death and spitting blood, had been removed to Cork Military Hospital to be force-fed. He commented:

It is not sufficient that these brave men should die, as Thomas Ashe had died, in defence of a principle. Their deaths must be made agonising and their bodies and souls tortured by the refined brutality of forcible feeding. Such are the methods a British government has been reduced to in its brutal attempt to destroy the soul and spirit of the Nation. ${ }^{33}$

One prisoner, Maurice Crowe, later recounted that he had indeed been informed that he was to be fed. However, negative media coverage seemed 
to have discouraged the prison doctors. As an alternative solution, the prisoners were transported to Pembroke Prison, England, where a further attempt was made to feed them. ${ }^{34}$

The British government never quite admitted that it no longer force-fed Irish prisoners. Senior politicians carefully evaded questions raised in the House of Commons about whether politicised prisoners were still being fed. ${ }^{35}$ Abandoning the rhetoric of 'artificial feeding' would have required backtracking on a decade of official statements on the safety of the practice and conceding some degree of responsibility for Ashe's death. It seems plausible that the government was also reluctant to entirely dispose of a potent weapon in its artillery at a time when Irish prison rebellion was intensifying. Nonetheless, both Dublin Castle and the British government remained cautious about force-feeding republican prisoners in Ireland, fearing it would prove too politically contentious. Moreover, the large numbers of prisoners on hunger strike during the War of Independence made the option less feasible. Considerable medical facilities, staffing, and resources would have been required to feed such a large number of prisoners. ${ }^{36}$ Even if these had been available, force-feeding occupied a dubious position in the Irish national psyche. It stirred resentment among the public as the stomach tube was now implicated as a lethal weapon in the ongoing Anglo-Irish struggle.

This scenario set the stage for new forms of hunger strike management and the formation of new relationships between doctors and prisoners. If, by 1917, force-feeding had been broadly agreed upon as unethical, it seemed that the Home Office and prison authorities had only two options left as predicted by Shaw: recommend early release or allow starvation to run its course. In February 1918, Mountjoy officials began to inform hunger strikers that they would neither be fed nor released. ${ }^{37}$ In the following month, John Irwin warned prisoners that the government was determined to stop authorising releases under the Cat and Mouse Act. ${ }^{38}$ This policy shift caused immediate unease among prison medical staff. Many still believed that death could occur in a matter of days of hunger striking. In 1912, the General Prisons Board had invited Dublin physician, Joseph O'Carroll, to Mountjoy to offer his expert opinion on how long Mary Leigh and Gladys Evans were likely to remain alive without eating. Leigh and Evans had been hunger striking for just two days. O'Carroll observed that the prisoners already appeared weak and cold, noting an acetone odour on their breath characteristic of starvation cases. He concluded that Mary and Gladys were already suffering physically from starvation 
and that de-nutrition was firmly established. If their protests continued, O'Carroll warned, the frail bodies of the prisoners would rapidly decay as their reserve supplies of consumable tissues expended. O'Carroll ominously predicted that it is dangerous to their lives to allow the starvation to go further' ${ }^{39}$ Evidently, prison medical staff shared a deep-rooted fear of the rapidity of human starvation during the suffragette hunger strikes. O'Carroll firmly believed that prisoners could endure starvation for just two or three days. In the 1910s, this belief had underpinned-indeed justified-force-feeding policies and informed decisions to resort to the stomach tube at an early stage of a hunger strike.

An absence of force-feeding policies changed the function of prison doctors who were no longer accused of torture but instead forced to adopt an uneasy palliative role in cases of severe prisoner health decline. Did this in any way ease the pressures that had been placed on certain prison medical staff since 1909? Initially, some doctors continued to intervene. When IRA (Tipperary) Officer, Eamon O'Dwyer, went on hunger strike in Cork Prison in 1918, an elderly doctor named Dr O'Flaherty attended him. Eamon later recounted:

He had me turned lying on my face and I got the impression he was doing something he shouldn't be doing in the way of forcible feeding, not in the way it was done in Mountjoy but forcible-feeding of another kind. I said "What are you trying to do?" and he said "I am giving you something to keep up your strength". "Well, my God", I said, "If you continue you may overpower me, but I'll tell you this, whenever I get out, or I will get word out somehow, I will have you killed". I was under the impression he was giving me forcible-feeding through the posterior passage. He desisted and said "I have only been trying to save your life".

It is unclear from this account whether O'Flaherty had been persuaded by senior prison staff to attempt a surreptitious rectal feeding or whether the doctor had acted on his own initiative to preserve Eamon's life. Nonetheless, O'Flaherty presented his actions as an act of kindness and sympathy. As Eamon continued:

Most of these doctors then thought that a week's hunger strike was dangerous. They got to know as time went on that a month's hunger strike wasn't a danger to a great many men. He said he was sorry. I said, "That's all right as long as you don't do it". He said, "It is a heartbreak for me to have you here, and if you die on my hands what will I do? Do you suggest I release 
you and lose my job?" "I have not suggested to you to do any such thing", I said, “and I have not asked you to release me. Don't do anything that will do yourself harm, Dr O'Flaherty. Don't try anything like forcible-feeding but, at the same time, I will let the hunger kill me before I will give up". ${ }^{40}$

Eamon's narrative suggests that he formed a relatively compassionate relationship with his doctor once force-feeding policies had been abandoned. O'Flaherty appears to have held conflicting emotions towards caring for a prisoner whom he believed to be dying ranging from genuine pity to a fear of being dismissed from his post. O'Dwyer appeared equally sympathetic to his prison doctor, perhaps realising the precariousness position of institutional medical staff as unwilling intermediaries between the government, prison officials, and republican prisoners. Eamon took care in his account to note O'Flaherty's concern with keeping him alive, despite firmly objecting to the attempted rectal feeding. It seems that O'Flaherty believed that feeding was preferable to death.

Notably, prison doctors still felt anxious about the potential legal implications of a prison death. In February 1918, the General Prisons Board suggested that legislation was urgently needed to protect medical staff against potential manslaughter charges. ${ }^{41}$ Many doctors remained ambiguous about overseeing self-starvation. Frank Gallagher recalled on his twelfth day of a hunger strike at Mountjoy Prison that his attending doctor seemed more afraid of a fatality than the prisoners themselves. 'He has stopped smiling, the doctor', Frank claimed, 'why should be be afraid? The men are not afraid-except a little at night when the mind will not stay quiet, but even Christ had that physical fear'. ${ }^{42}$ Medical staff working in hospitals close to prisons were also concerned about their legal standing. In the same month, Limerick County Infirmary physician, J.F. Devane, telephoned the General Prisons Board to discuss a hunger striker under his care. Devane announced that he would take no responsibility should the prisoner die. ${ }^{43}$ Evidently, new hunger strike management policies caused disquiet among medical staff. Those who had previously force-fed had the safeguard of medical duty to fall back upon, as well as the legal precedent of Leigh $v$ Gladstone. Yet being expected to oversee death was uncharted ethical and legal territory. It was only in 1920 that the government clarified the position of prison medical officers by formally specifying that civil or criminal responsibility for a death would not rest on a staff member in charge of a hunger striker. ${ }^{44}$ But other threats existed. Prison staff maintained an uneasy relationship with the IRA who regularly dispatched death threats to prisons where a hunger strike was taking place. One posted 
to the Governor of Cork Prison in 1920 read: 'If any of these men are allowed to die, the soldiers of the Irish Republican Army in this country will at once take action of the most drastic kind to avenge the murders. ${ }^{45}$

For many reasons, certain prison doctors in Ireland refused to participate in hunger strike management with the enthusiasm desired by the General Prisons Board as they either sympathised with the prisoners or had little desire to become entangled in the exigencies of conflict. When the General Prisons Board requested that Dr Flynn, medical officer at Cork Prison, write a separate medical report for each prisoner, Flynn emphatically refused unless he was paid a guinea per hunger striker, adding that 'they can throw me out if they like'. Flynn insisted that the hunger strike was a moral cause requiring daily visits by a chaplain, not a medical problem. ${ }^{46}$ Earlier, Flynn had refused to force-feed. ${ }^{47}$ Similarly, in June 1920, Flynn made clear in a telephone message to the General Prisons Board that he would assume no further responsibility for one ailing hunger striker under his care and recommended his immediate transfer to a local hospital. ${ }^{48}$ Flynn regularly endorsed the early release of prisoners by claiming that they were suffering from conditions such as valvular heart disease or myocardial degeneration. His zealousness in diagnosing heart conditions soon drew the attention of members of the Board who began to over-rule his recommendations. ${ }^{49}$

Whereas force-fed suffragettes and republicans such as Thomas Ashe had been emotively presented as powerless, vulnerable victims of a government intent on causing physical harm with the use of medical technologies, it seems clear that starving hunger strikers possessed greater control of their actions. They had more autonomy than force-fed prisoners, particularly if they possessed the self-control and determination needed to abstain from food indefinitely for an important moral cause: securing an independent Ireland. The shift towards permitting self-starvation allowed hunger strikers to become actively involved in their own institutional fate and harness control of their environment in a manner that the passive, but aggressively weakened, victims of force-feeding had been unable to. They had been granted permission to subvert the normal disciplinary workings of the modern prison by reclaiming bodily autonomy. Diverse encounters ensued between medical staff and hunger strikers. Most doctors felt uneasy about overseeing self-starvation. Although some were undoubtedly wary of courting adverse publicity or being prosecuted, others sympathised with the hunger strikers (perhaps irrespective of whether they agreed with their broader cause). Doctor-patient interactions were now discernibly more compassionate in nature. 


\section{EXPERIENCING STARVATION}

What is it like to be on hunger strike? How is fasting experienced physically and emotionally? And do doctors perceive the distressing spectacle of self-starvation as any less problematic than force-feeding? Republican prisoners left an abundant supply of autobiographical material that offers insight into deeply personal aspects of their hunger strikes. These differ from sources such as suffragette propaganda as they were mostly written, recorded, and published long after the revolutionary period. In contrast to suffragette accounts of force-feeding penned during their campaign for the vote, most autobiographical republican literature was not intended to stimulate immediate change in state policies or attract public support for a pressing political cause. It was written some time after. First-person testimony of prisoner experiences is contained in sources including the Bureau of Military History oral history witness statements collected by the Irish state between 1947 and 1957 and in published accounts such as Frank Gallagher's Days of Fear (1928). ${ }^{50}$ The physical, psychological, and emotional strain caused by abstaining from food figures prominently in their accounts, indicating that hunger striking occupied a central place in the shared memory of the War of Independence and Civil War and informed how republicans subsequently articulated their historical experiences.

The production of these sources inevitably involved a certain extent of retrospective self-fashioning that reflected a tendency in independent Ireland to remember those involved in the events leading up to independence as heroic and victorious. While some authors openly admitted that they considered abandoning their hunger strikes, the overwhelming majority emphasised their determination and resolve to persevere with fasts that sometimes lasted for weeks. As Alannah Tomkins argues, the process of self-presentation historically embodied in the production of autobiographies can influence the inclusion and omission of events. Moreover, many autobiographical texts or interviews make extensive use of established motifs or narratives. ${ }^{51}$ Certainly, sources such as the Bureau of Military History witness statements tend not to provide details on prisoners who refused to participate in group hunger strikes or who gave up after a few days. ${ }^{52}$ Oral history sources are also notoriously problematic due to issues such as memory, bias, and impartiality. In addition, Gallagher was a master at producing republican propaganda meaning that his rendering of his prison experiences was structured by the impression which he sought to create of his endurance for the cause of an independent 
Ireland. ${ }^{53}$ From republican perspectives, the prison was not a site of personal rehabilitation but a space in which injustice (often, internment) existed, a view that ensures that the hunger strike narratives recorded in this format depict a bodily struggle and, in many instances, victory against a multitude of institutional and state forces.

On a quiet evening at Mountjoy in 1919, prison staff heard an unexpected commotion. Upon inspecting, they encountered a group of republican prisoners setting fire to their beds, smashing their windows, and wrecking their cells. A clear signal had been sent: A hunger strike was underway. The prison warders subdued the rebellious prisoners with fire hoses. ${ }^{54}$ It was common for prisoners to announce hunger strikes with displays of disruptive behaviour. In 1920, fifty prisoners broadcasted their intention to hunger strike at Wormwood Scrubs by simultaneously tearing down their cell doors, initiating a battle of wills between staff and prisoners. ${ }^{55}$ Prison warders placed steamed kippers in the prisoners' cells, hoping to entice them to eat. Windows were smashed and the food thrown outside. A member of the Home Office then visited the prisoners promising concessions if the protest was called off. The prisoners refused to move from their beds to listen to him. ${ }^{56}$ Five days into the protest, warders began to supply better quality food to all prisoners. ${ }^{57}$ The hunger strikers refused to budge. Starvation was allowed to ensue.

At the time, doctors knew very little about the physical and emotional processes of starvation. They learnt gradually through day-to-day observation. Scientific research into human starvation was in a nascent state. American physiologist, Francis Gano Benedict, had published an important study in 1915 based on his observations of a man who had agreed not to eat for thirty-one days. ${ }^{58}$ Yet it is unlikely that English and Irish prison doctors were familiar with this research. Physiology tended to be viewed as a somewhat abstract discipline with relatively little clinical value. ${ }^{59}$ In many ways, the bodies of prisoners generated knowledge as they decayed. Attending physicians learnt to recognise characteristic symptoms such as decreasing heart rate and physical wasting, even if the precise nature of the physiological processes of starvation remained unclear. ${ }^{60}$ They saw the bodies of hunger strikers rapidly decay during the first week of fasting, arousing fears of imminent death. Indeed, the speed of this initial decline had previously encouraged prison doctors to force-feed. The hunger strikers' bodies were quickly exhausting the fat reserves held in the adipose tissue. Once these had depleted, their bodies set to work consuming the glycogen stores, a secondary energy store located in the liver and mus- 
cles. Ammonia was produced at this stage, creating the distinctive smell observed by Joseph O'Carroll when he visited the suffragettes imprisoned at Mountjoy in 1912. However, this ammonia was then excreted with keto acids to spare sodium loss and decrease the speed of weight loss. Physical decay began to slow. Doctors also saw other physical symptoms at this early stage including a loss of heart mass and the development of bradycardia, a resting heart rate of less than sixty beats per minute. ${ }^{61}$ It was this slow pulse that had encouraged doctors to force-feed just days into a hunger strike and pay close attention to the heart rate of prisoners including Constance Lytton (but less so with Thomas Ashe). ${ }^{62}$

During their first week of hunger striking, prisoners experienced various physical and emotional sensations. Sinn Féin MP, Constance Markievicz, privately wrote, 'I only did three days and I was quite happy and did not suffer at all. I slept most of the time and had lovely dreams and time went by quickly.' ${ }^{63}$ Many prisoners felt surprisingly little longing for food. Frank Gallagher recorded in his diary:

[I] noticed in yesterday's papers that some French journalist spoke of our 'pangs of hunger'. Nobody would ever believe that there are none. There is revulsion at death, a wild longing to live, but no physical call for food. That ceased on the second day. Now tastes and smells are pleasant to think of, but mean nothing. If the mind took the fast as quietly as the body does, the whole thing would seem like a joke, there would be so little suffering in it. If our friends outside would believe this. But it is true and they never will. ${ }^{64}$

Others seemed to have coped less well. IRA (Southern Division) member Seán Moylan recounted:

Day after day I found my mind preoccupied with the devising of menus. Elaborate and often incongruous combinations of food-flesh, fruit, vegetables-passed on the assembly belt of imagination before my eyes leaving the craving that encompassed me more insistent as the days went by. At no time, however, did this delicious dream of food tend to weaken my determination to continue the strike. Spirit triumphed over matter ... it makes clear the point that before a man can live spiritually he must have a physical being; the measure of man's spiritual development is the extent of his control over the body's demand. ${ }^{65}$

Despite recalling contrasting experiences of food cravings, both Frank and Seán called attention to the pride that they felt in having conquered 
physical hunger using will power and mental determination. Seán, in particular, presented his struggle against hunger as a spiritual feat, exemplifying the sense felt by many imprisoned republicans that hunger striking served a spiritual purpose.

Feeling hungry was not the only problem. Prison meals were central to the monotonous sense of time and routine that structured prison experiences. ${ }^{66}$ Food serves important disciplinary purposes in prisons. Tedious meals and the serving of poor quality food can form part of the punitive landscape of the prison, providing a potent reminder of the liberties that prisoners leave behind after choosing to commit crime. ${ }^{67}$ Nonetheless, by refusing to eat, hunger strikers severely disrupted their daily routines. After seven days of hunger striking, Frank Gallagher recalled:

Tonight my head aches. Those first days of hunger-striking are cruel days. Yet the hardest thing of all to bear is that there are no meal hours. Jail life hinges on the three meals. It is morning, and one is brisk and vigorous because the tin at the door has porridge in it. It is afternoon, and a calm studiousness invades the mind because the contents of that tin are soup and potatoes. It is drowsy evening, and one begins to yawn because soup and potatoes have given way to cocoa and crusted bread and now there is no division of the day, no beginning and no end. The head aches, the body is damp and weak. Even sleep has gone. ${ }^{68}$

The lack of institutional routine without food seems to have deeply affected Gallagher who faced monotony and boredom without the distraction of meal times to break up the tedium of institutional life. After eleven days of hunger striking, Gallagher began to rave about clocks, perhaps a further indication of the centrality of perceptions of time to his experiences. ${ }^{69}$

Until 1920, prison doctors remained highly concerned about the prospect of death during this initial stage of fasting. Reportedly sympathetic doctors at Limerick Prison tended to release hunger strikers after seven days without food. ${ }^{70}$ Prisoners also played on the fears shared by their doctors. Robert Brennan was imprisoned at Cork Prison during 1917. He later recalled that the prisoners deliberately made medical staff nervous by constantly pretending to be ill. On one occasion, Robert recollected, 'when the strike was only five or six days old, we arranged that one of our fellows should collapse and be carted off to hospital, but before he could do so, another man actually did collapse. The doctor, in a panic, recommended our immediate release. ${ }^{71}$ Similarly, Terence MacSwiney 
once jovially placed his bare feet on the cold hot-water pipes while hunger striking prior to a visit from his prison doctor. Cold feet were recognised as a symptom of heart disease. ${ }^{72}$ Seán Moylan went further. He decided to feign insanity. When being examined by the prison doctor, Moylan refused to do anything but snarl when touched. Upon being provided with food, Seán leapt frenziedly out of bed, grabbed the tray, and hurled it at the window shouting 'poison' repeatedly. Rumours circulated around the prison that a hunger striker had gone insane. Prisoners kicked down doors and broke windows. Seán later recalled that 'the unfortunate prison governor and doctor were far nearer to mental derangement than I ever pretended to be'. ${ }^{73}$

Conditions for hunger strikers tended to be worse in English prisons. Accounts of going on hunger strike in England tend to be far less jovial. In 1920, IRA (Kerry) Commandant, Thomas Treacy, was dispatched by ship from Belfast Prison to Wormwood Scrubs during the first week of a hunger strike. He recalled the voyage as traumatic. Handcuffed in pairs, the prisoners suffered from violent seasickness and empty retching. ${ }^{74}$ When Denis Morgan delivered his evidence to the American Commission on Conditions in Ireland in 1921, he recounted that he and his fellow prisoners had broken down their cell doors at Wormwood Scrubs in protest against the cell doors being locked at night. This would have allowed the healthier hunger strikers to attend the weaker. Morgan recounted thus:

We were taken out of the cells where we were and thrown into what are called punishment cells. We were three days on hunger strike at this time and were getting pretty weak. These punishment cells are in the basement, low down. They had not been opened for twenty years, I think. They were very small and close and the dust was thick in them.

Denis added that the size of the cells was only twelve by eight feet and that the prisoners remained imprisoned there for four days without being offered water to wash with. ${ }^{75}$ Similarly, IRA (Derry Brigade) member, Patrick Rankin, recounted that Wormwood Scrubs prisoners were forced to share single cells with up to five other prisoners. Rankin recounted that 'our health was not going to be improved under those conditions ... in our ground floor cells we were packed like cattle-no room, poor ventilation, overcrowded floor space'. ${ }^{76}$

It was only after around seven days of hunger striking that the physical and mental condition of prisoners significantly worsened. During the 
Civil War, detainees at the Gormanston Camp, Co. Meath, organised their own medical service during a mass hunger strike. Prisoners were divided into hunger strikers and those who would provide care by nursing, making beds, and cleaning. One of the key duties of the quasi-medical staff was to ensure that a palatable water supply remained available. They supplied hunger strikers with boiling water mixed with salt and pepper (nicknamed 'soup' by the prisoners), a mixture believed to minimise the harmful effects of fasting. ${ }^{77}$ On the seventh day of this protest, IRA Captain (Dublin), Seán Prendergast, recalled that a number of men took to their beds exhausted and weak. He recollected his experiences of providing care as follows:

Night duty was the worst of our ordeals. It was uncanny, weird and singularly unpleasant to sit at the fire ... there to listen to the moanings and groaning of some of the men and to witness others as they tossed, turned and moved in their beds in troubled unsatisfying sleep or at other times being suddenly called to pay attention to one or more men, or requests for drinks of water... some would dream, openly and aloud, much of it and indeed much of their dream talk and sleep 'ramblings' concerned food, the lovely tasty and appetising meals they sometimes had, thought they had or would like to have ... how such talk must have jarred their nerves and added to their other misery in not being able to sleep. ${ }^{78}$

By this stage, sustained food abstinence had resulted in dramatic calorie restriction which produced megalomaniac and persecutory delusions, auditory hallucinations, somatisation, dissociation, and confusion..$^{79}$ As Seán suggested, it was at this stage that the emotional state of many of the prisoners deteriorated. In the initial days of their protest, hunger strikers had taken pride in their ability to use mind over matter. After seven days, they soon developed hallucinatory tendencies made worse by an inability to sleep.

Frank Gallagher recollected vivid hallucinations coupled with sleeplessness on his eleventh night. He recorded in his diary:

Must have raved all night. Thought I was stronger than that. But this sleeplessness is unbearable. But even an uncontrollable imagination darting in and out among dark thoughts, searching the closets of the mind, tearing up the very floorboards of the soul, could not find the idea of compromisethat gives me great strength. My weakness is physical, nervous only. ${ }^{80}$

Frank's account suggests that the psychological changes that occurred during fasting in no way impaired his competence or produced severe 
mental deterioration. The changes that took place tended to be emotional (such as an increase in anger or anxiety). But he remained able to make a competent assessment of his situation. ${ }^{81}$ Gallagher also noted that his experiences were common among his fellow hunger strikers. On his thirteenth night, he recorded:

Men are nearly mad now. Some of the other men, I know, but I am not mad. They are trying to make me mad. They are sending men to watch for me fear I should sleep. Telling the sentries to shout when I seem like sleeping. I am perspiring. Curious delusion that was. It has made me weak.

Evidently, Frank had begun to experience paranoia about the prison staff. Yet his accounts suggest that he remained relatively lucid, drifting in and out of delusions but mostly conscious that his paranoia was not real. Gallagher provided an account not of a gradual descent into mental illness but instead of constantly shifting emotional states. As he also wrote: 'I must fight all these mad thoughts when they come, the moment they come. Otherwise they will eventually crowd in and stay in and... Ugh! Better not think of that. It will come if we have much longer to lie here awake but it has not come yet. ${ }^{82}$

At around ten days of hunger striking, many prisoners became bed bound. Glycogen stores were exhausted and muscle loss had ensued, particularly around the heart. Once $18 \%$ of the body's weight had been lost, serious physical problems arose. The main disabling symptoms were faintness and dizziness. ${ }^{83}$ During the War of Independence, most prison doctors recommended discharge after ten days, and not normally after fifteen. Upon release, hunger strikers tended to be hospitalised. During his second hunger strike of March 1920, Mountjoy medical staff discharged Maurice Crowe to the Mater Hospital, Dublin, after ten days without food. Maurice kept his medical chart until at least the 1950s which included entries such as 'temperature 103. Condition: very weak'. He remained in hospital for a fortnight. ${ }^{84}$ In the following month, the Visiting Committee at Mountjoy reported that twenty-two prisoners had collapsed overnight after fasting for ten days. The Committee recommended early release. ${ }^{85}$ In 1923, after her tenth day of hunger striking, a doctor at Mountjoy reported that Mary MacSwiney (sister of Terence) was dangerously weak. She seemed to need food, stimulants, and special nursing if she was to remain alive. ${ }^{86}$ As the physical condition of prisoners gradually weakened and prison doctors came to fear death, hunger strikers in England were also transported by 
ambulance to nearby civilian hospitals. Edmond McGrath was moved to St. James Hospital, Highgate Hill, London, after fasting for nineteen days. After spending a number of days recuperating, the London branch of the Irish Self-Determination League paid for his fare home. Edward returned to Ireland by boat still feeling weak and sick. ${ }^{87}$

Most prisoners who had been fasting for over a fortnight needed a careful recuperation period. However, rapid re-alimentation could be potentially dangerous as ingesting carbohydrates after fasting rapidly reverses many of the physiological processes of starvation, causing measurable weight gain and potentially acute oedema (an excessive build-up of fluids in the body). Heart problems were a further potential hazard. A sudden increase in fluid volume can precipitate heart failure. ${ }^{88}$ The quality of aftertreatment available to recuperating prisoners varied, as did patient compliance. Many prisoners developed their own networks of care both inside and outside of the prison. By hunger striking, they came to understand what happens to the human body without food. For instance, they became progressively aware that eating needs to be resumed slowly after a hunger strike. When Mountjoy officials released the remainder of the prisoners on hunger strike following Thomas Ashe's death in 1917, the group recuperated in Mahony's Hotel, Dublin, where IRA (Wexford) officer, Paddy Brennan, instructed them not to consume solid food until advised to by the doctor called in to provide care. Nonetheless, William McNamara and Jack Madigan slipped out that night and drank numerous bottles of stout. Upon returning to the hotel in the early morning, they discovered that many of the released prisoners had surreptitiously eaten ham sandwiches, despite having been given advice to the contrary, and now appeared close to death. ${ }^{89}$

Upon becoming hospitalised, prisoners found that doctors had varying levels of knowledge about how to recuperate hunger strikers. When IRA (Tipperary) Officer, Seán O'Carroll, was dispatched from Wormwood Scrubs to Highgate Hill Hospital, his doctor had no understanding of the effects of hunger striking, even though many of the prisoners understood the basic principles. Seán knew full well that he should not consume solid food for at least a week. Other prisoners fared less well. Fed with bread and butter while hospitalised, fifty recuperating patients began to suffer from violent heartburn and crippling stomach pain..$^{90}$ Evidently, the informal networks of bodily knowledge accrued by prisoners were not necessarily shared by the doctors who attended them. However, it is important to note that some prisoners had more 
favourable experiences. On the twentieth day of his hunger strike, James Rankin was discharged to St. James Infirmary and put under the charge of two nurses, several layman orderlies, and a doctor. He later remembered receiving far better medical attention than he had in prison, and even at home in Ireland. His doctor performed a minor operation which James believed had saved his life. His local doctor in Ireland had been relatively indifferent to James's agonising stomach pains. The doctor at St. James Hospital also seemed more aware than his colleague at Highgate Hill that hunger strikers needed to resume eating at a moderate pace. Rankin recollected that the hospital staff were kind and thoughtful and allowed visitors to provide food. 'The doctor became alarmed', Rankin recalled, 'that we would overeat in our delicate state of health but he was needlessly alarmed as he did not know the capabilities of an Irishman's stomach'. After a few weeks in the hospital, Rankin escaped after securing a day pass from a Scottish doctor. ${ }^{91}$

It is worth noting that lower levels of medical care seem to have been provided for hunger strikers during and following the Civil War, a problem that encouraged prisoners at Gormanston Camp to fend for themselves. Seán Prendergast vividly remembered the fifteenth day of the mass hunger strike as:

A critical moment in relation to the strike and effecting [sic] the general welfare of the men involved. It was a tense and anxious time for us who were attending to the wants of so many frail men. Some of them were barely hanging on to life by slender threads while even the strong and burly were showing signs of physical weakness under the strain and rigours of that long food fast. Our hut, other huts also, registered an uncommon number of bed patients. A few of the more robust were sticking it out more by will power and a strong governing spirit than any other known or unknown reason. ${ }^{92}$

The leaders called off the Gormanston hunger strike on the sixteenth day. Seán partook in a slow process of helping the hunger strikers recover their health. Immediately after the strike had finished, the prisoners were given hot milk and advised not to consume coarse food. Light dishes were provided. ${ }^{93}$ Evidently, by the Civil War, hunger strikers were aware of the circumstances of bodily decay that result from prolonged fasting and the therapeutic strategies required for successful recovery. If anything, the existence of a quasi-medical service at Gormanston demonstrates the extent to which republicans informally understood the 
physical, psychological, and emotional implications of hunger striking even if many doctors remained less familiar with the physiological effects of self-starvation.

Notably, a shared understanding of fifteen days as a likely danger point fostered reluctance among some prisoners to hunger strike. IRA (Dublin) member, Stephen Keys, reluctantly went on strike at the Curragh Camp during the Civil War. Keys was determined not to abstain from food for any longer than fifteen days as a rumour had circulated around the camp that 'after fifteen days on hunger strike, you lived on the marrow of your bones and that you were likely to be a cripple for the rest of your life'. Keys recounted that up to 600 individuals broke the hunger strike on the fifteenth day. Although initially provided with small drops of Bovril, Keys witnessed one prisoner consuming large quantities of food from a swill bucket once the strike had been called off. The prisoner collapsed and was taken away on a stretcher. "Two or three men happened to die from the same thing', recalled Keys, 'eating too much and not being able to get to hospital quick enough'. ${ }^{94}$

Evidently, autobiographical evidence demonstrates that physical and emotional trauma was salient in the landscape of the revolutionary-period prison. The majority of republican prisoners who went on hunger strike were released between around ten and fifteen days as alarm rose about their decaying bodies. Initially, prison doctors believed that the rapid physical and psychological decay evident in the first few weeks of a hunger strike signalled imminent death. While doctors treated their patients with varying degrees of compassion, they deeply feared a controversial prison death. Notably, hunger strikers developed an intimate knowledge of what happens to their bodies while fasting. They came to understand the physical and emotional effects of starvation, recognised potential danger points, and accrued knowledge about recuperation. Informal networks of bodily knowledge were formed during the hunger strikes of this period that equalled-if not bettered-that possessed by doctors. It seems clear that the abandonment of force-feeding policies produced a range of bodily and emotional circumstances. Bodies decayed, prisoners hallucinated, and some struggled to recuperate. This was a situation that many doctors who supported force-feeding deeply wished to avoid. Patient autonomy was seen as important, yet doctors struggled to weigh the need to grant autonomy against the physical consequences of overseeing starvation. 


\section{Overseeing Death}

Republican hunger strikes rarely lasted beyond fifteen days. Rather than let starvation run its course, prison doctors favoured early release. Politicians needed the backing of the British public for its campaign in Ireland which might have been hindered by an unfavourable prison death. Moreover, the government continued to believe that moderate Irish nationalists might be won over to the British cause until 1920. Michael Biggs suggests that a prisoner, by dying, would have signalled the deepness of his or her conviction in the justice of his cause, giving a convincing impression that the institutional circumstances that had resulted in a hunger strike were truly intolerable. ${ }^{95}$ However, in 1920, the government did allow some prisoners to starve to death. In Spring, Michael Darven was transferred to Mountjoy's hospital after twenty days of hunger striking. Three doctors visited him daily to assure him that there was no hope for his life. As his condition worsened, doctors and priests visited Michael hourly believing that he was only hours away from death. Throughout May, thousands of locals kept vigil outside the prison gates. Despite his woeful condition, the Home Office dispatched a proclamation which was read out to Michael stating that release was not an option. Michael later recounted that 'the three doctors were in tears and it was quite clear that their sympathy was with us, as medical men'. Ultimately, the government gave way. Prison doctors released Michael under the Cat and Mouse Act and conveyed him through the dense crowds outside the prison to the Mater Hospital. ${ }^{96}$

Nonetheless, the government remained determined not to continue caving in to hunger strikes. In August, a mass hunger strike commenced in Cork involving sixty IRA members, most of whom were being held without charge or trial. The British released or transferred most of the prisoners until only eleven were left. One prisoner, Terence MacSwiney, was transferred to Brixton Prison, London, where he continued his hunger strike. Terence had been arrested in Cork for possessing seditious documents and a cipher key. He died while on hunger strike, while two prisoners, Michael Fitzgerald and Joseph Murphy, died in Cork. These prisoners were allowed to starve as the government feared a mutiny among the disgruntled military and police in Cork. The group hunger strike in Cork eventually stopped in November at the request of Arthur Griffith, acting President of the Irish Republic. ${ }^{97}$ Although autobiographical material detailing the experiences of republican hunger striking beyond around twenty days does not exist (as hunger strikers had been released or were 
too weak to speak and write), insight into their physical, psychological, and emotional experiences can be gleaned from sources including Terence MacSwiney's medical reports, collated daily by the Home Office, and the Cork Examiner which printed regular interviews with visiting family members and friends.

The prolonged hunger strikes of 1920 made clear for the first time that human starvation could ensue for far longer than a fortnight. Indeed, these protests continued for over sixty days. The severity of physical and mental weakening, reported internationally in graphic detail, allowed images to circulate on the horrific impact of hunger striking on the human body that rivalled earlier depictions of force-feeding in their horror and intensity. The public spectacle that ensued led to international condemnation of British policies and generated deep concern over the welfare of Irish prisoners. ${ }^{98}$ Twenty days into the hunger strikes, the Cork Examiner ominously announced that 'the climax of the hunger strike in Cork Gaol is now at hand and will probably be reached in the next twenty-four hours'. ${ }^{99}$ However the hunger strikers did not die as quickly as expected. When Michael O'Reilly's sister visited him on the twenty-first day, she reported: 'My brother is very weak. His lips are cold. His hands are clammy, and his pulse is beating very slowly. He is much worse today. When he looked at me, with watery eyes, I was startled with his shrunken and haggard appearance.' Seán Hennessy's mother reported that he was suffering from blood poisoning in his heavily swollen leg and had lost his ability to speak. ${ }^{100}$ Two prisoners collapsed on the twenty-third day, raising concerns that their health would never be restored even if they were released. Seán Hennessy struggled to concentrate when his father read him extracts from a newspaper while Bourke complained of intense pains in his head and stomach. ${ }^{101}$ On the twenty-sixth day, Thomas Donovan collapsed, having begun to suffer from an abscess in the mouth creating fears that septic poisoning was developing. ${ }^{102}$ At this point, the prisoners began to object to visits being made by their doctors, arguing that if the position of his government was to let them die, then medical staff should let them die in peace. ${ }^{103}$ Sharing similar fears about the prospect of death, upon the twenty-sixth day of Terence MacSwiney's hunger strike, the Home Office requested daily reports on his health. The attending prison doctor visited Terence every two hours during working hours to compile his bulletins. By this stage, Terence was in a weak condition, but still conscious. He was dizzy and weak, and prone to sudden changes in his condition. He had begun to suffer from severe back and limb pains as well as constant dizziness. ${ }^{104}$ 
But even after twenty-six days, the prisoners remained alive. After thirty-three days, the prisoners in Cork no longer had the strength to speak. They barely slept at night and were unable to recognise their visitors. Ex-County High Sherriff, Philip Harold Barry, attempted to intervene by sending a telegram to General Officer Commanding-in-Chief, Neville MacReady, in which he stated that 'it is very difficult to understand how the prisoners are alive at all', especially given that they had refused medical attention. Notably, MacReady observed that the prison doctors expressed deep sympathy with the men who were now being nursed by volunteer nuns. ${ }^{105}$ Fully aware that the prisoners and relatives might view them as agents of the British administration, medical staff made clear to the public that they were willing to step aside and allow neutral doctors to attend the patients if their families wished. ${ }^{106}$ Whereas a significant corpus of medical men had previously viewed force-feeding as unethical, it appears that prison doctors employed at Cork Jail felt similar unease about having to oversee self-starvation.

After around thirty-five days, the regional press stopped discussing death as imminent. Instead, they began to comment on the miraculous longevity of the prisoners. 'In the history of hunger strikers', reported the Cork Examiner, 'this is presumably a record'.${ }^{107}$ From here on, journalists began to valorise the perseverance of the hunger strikers in battling both the British government and human nature for the moral cause of securing an independent Ireland. As Murphy argues, the press told the stories of their deaths in ways that offered solace and admiration rather than condemnation. ${ }^{108}$ The Cork Examiner wrote:

The hunger strikers in Cork and Brixton still maintain their struggle with death, and wonder grows at their marvellous endurance and sets precedent at nought. Sustained by unswerving faith in the justice of their cause, these exhausted youths and men continue to make their protest, even though they are convinced that it entails the ultimate sacrifice. ${ }^{109}$

After enduring thirty-seven days on hunger strike, the Home Office raised the number of reports compiled daily on Terence MacSwiney's health to six. Their content differed little until the fiftieth day of Terence's fast. Each day, the attending doctor repetitively reported that the former Lord Mayor remained conscious with his condition having changed little since the issuing of the previous bulletin. ${ }^{110}$ Bereft of gruesome details of physical decay to report on, a journalistic rhetoric evolved that helped 
to transform the hunger strike into something miraculous, as a psychological victory of endurance and a spiritual triumph of mind over matter.

In October 1920, a number of rumours (or, as James Vernon describes them, carefully calibrated leaks) emerged that Terence MacSwiney was being secretly supplied with food, a claim intended to demystify the hunger striker's lengthy fast. ${ }^{111}$ The medical profession quickly rebutted this suggestion. In October, the Medical Press and Circular rejected insinuations that individuals who abstained from food for longer than a month were surreptitiously consuming food by scouring the medical literature to examine the careers of professional fasters who had survived without food for up to fifty days. 'An energetic and determined will', explained the Medical Press and Circular, 'whether it be sane or insane, is the strongest weapon man can oppose to inanition'. ${ }^{112}$ Similar suspicion about prison activities also emerged in Ireland. On the fortyeighth day of the Cork Gaol hunger strikes, two doctors (Drs Learson and Battiscombe) agreed to be interviewed by the Cork Examiner and expressed their amazement that eleven hunger strikers in Cork Prison remained both alive and semi-conscious. The doctors took care to ridicule rumours that the nuns caring for the prisoners were disguised Government nurses. ${ }^{113}$

It was on the fiftieth day of hunger striking that Terence MacSwiney's physical condition rapidly deteriorated as he entered into a state of complete exhaustion. Six days later, his doctor wrote, 'it causes him great distress to say even a single word. He tries to whisper something, gasps, becomes very exhausted, and then cannot continue. ${ }^{114}$ Between days sixty-seven and seventy-four of his hunger strike, Terence developed scurvy, although his wife refused to feed him the recommended lime and orange juice. The prison doctor also reported that Terence's mental condition had worsened, noting that he was suffering from a violent delirium caused by prison officials having placed meat juice in his mouth. "They have tricked me and I did not know it", he exclaimed, "take it away! Take it away!" Terence MacSwiney died on 25 October 1920 after enduring a seventy-four-day hunger strike. ${ }^{115}$ His treatment in England differed profoundly from his fellow prisoners in Cork where prison doctors had shown greater respect for the wishes of the prisoners and their families. Michael Fitzgerald died in Cork Gaol on 17 October 1920 after enduring a hunger strike of sixty-seven days. ${ }^{116}$ On 25 October, a further untried prisoner, James Murphy, died after a fast of seventy-six days, on the very same day as Terence MacSwiney. ${ }^{117}$ 
To some surprise, the longevity of these hunger strikes firmly demonstrated that humans could potentially survive without consuming food for over two months, even in unfavourable prison conditions. This revelation added important new contours to ongoing debates on hunger strike management. Nonetheless in the public eye, allowing prisoners to slowly starve over protracted periods of time was deeply objectionable. Self-starvation was widely understood only as a quasi-suicide, as a necessary protest predicated, in this instance, to add weight to the legitimacy of the republican cause. It could still be construed as a form of violence being used by a government who had alternative options available such as recommending early release, granting concessions, or bringing internees to trial. In its eagerness to avoid a further controversial death associated with force-feeding, the British government helped to create a new, perhaps more dangerous, type of Irish martyr, one who could be construed as a victim of British policies of bodily repression in the way that Thomas Ashe had been valorised as an individual with a sound moral cause suffering a self-imposed atonement for a broader spiritual and political cause: Irish independence.

\section{Conclusion}

Between 1917 and 1923, hunger strike management policies in Ireland rapidly adjusted. Although the Home Office refused to formally acknowledge that force-feeding was potentially life-threatening, even despite the irrefutable evidence of Thomas Ashe's death, it gradually abandoned the practice. The War of Independence and Civil War placed new pressures on prison medical staff as republican prisoners mobilised to undertake a series of (often successful) hunger strikes as part of their attempt to disrupt key institutions of the British administration. Although the Home Office officially stated that it would no longer release prisoners prematurely under the Cat and Mouse Act, in practice the vast majority of hunger strikers were released between around ten and fifteen days of fasting. Throughout much of the period of conflict, prison doctors believed that prisoners would not be able to endure fasting for any longer. Hunger strikers displayed a range of physical, emotional, and psychological conditions, causing considerable alarm among prison medical staff who tended to recommend early release. The hunger strikes of 1920 decisively demonstrated that humans could in fact sometimes remain alive without food for periods of over two months. Yet rather than easing the pressure on prison officials to either force-feed or support early release, the graphic 
and well-publicised details of long-term starvation aided the cause of the rebellious prisoners, attracting widespread sympathy even among those not naturally allied to the militant cause.

It seems clear that policies of permitting self-starvation place pressure on prison medical staff, albeit in different ways than force-feeding. Self-starvation disrupts the normal workings of prisons, leaving medical staff bereft of their normal technologies of discipline and punishment and granting prisoners bodily autonomy in a system deliberately curtailed to curtail personal independence. Although force-feeding has always been associated with brutality and torture, it fulfils the idea that doctors have a medical duty to preserve health and save lives. In the absence of forcefeeding policies, doctors are obliged to stand back and watch groups of prisoners mutilate and damage their own bodies, sometimes irreparably. They find themselves in a situation where healthy, young politicised prisoners inflict harm upon themselves and refuse medical intervention. It is common practice today for hunger strikers to be left to their own devices (with Guantánamo providing an important exception). Yet doing so is physically and emotionally traumatic for both prisoners and doctors, a problem that goes some way towards explaining why many prison doctors, when faced with hunger strikers, might feel a need to provide food, even if this does involve resorting to a painful, degrading procedure.

\section{Notes}

1. For discussion, see James Rachels, 'Active and Passive Euthanasia', in Nancy S. Jecker, Albert R. Jonsen and Robert A. Pearlman (eds), Bioethics: An Introduction to the History, Methods and Practice (London: Jones and Bartlett, 1997), pp. 77-82.

2. Terri R. Fried, Michael D. Stein, Patricia S. O'Sullivan, Dan W. Brock and Dennis H. Novack, 'Limits of Patient Autonomy: Physician Attitudes and Practices Regarding Life-Sustaining Treatments and Euthanasia', Archives of Internal Medicine, 153:6 (March 1993), pp. $722-8$.

3. For exceptions, see Ancel Keys, The Biology of Human Starvation (Minneapolis: University of Minnesota Press, 1950); M. Başoğlu, Y. Yetimalar, N. Gürgör, S. Büyükçatalbaş, T. Kurt, Y. SeÇil and A. Yeniocak, 'Neurological Complications of Prolonged Hunger Strike', European Journal of Neurology, 13:10 (October 2006), pp. 1089-97.

4. Gerard A. Hauser, 'Body Rhetoric: Conflicted Reporting of Bodies in Pain', in Simone Chambers and Anne Costain (eds), Deliberation, 
Democracy and the Media (Lanham: Rowman and Littlefield Publishers, 2000), pp. 135-55.

5. Assistance in Hunger Strikes.

6. Daniel M. T. Fessler, 'The Implications of Starvation Induced Physiological Changes for the Ethical Treatment of Hunger Strikers', Journal of Medical Ethics, 29 (2003), pp. 243-7 on p. 244.

7. Francis J. Costello, Enduring the Most: The Life and Death of Terence MacSwiney (Kerry: Brandon Book Publishers, 1995); Dave Hannigan, Terence MacSwiney: The Hunger Strike that Rocked an Empire (Dublin: O’Brien Press, 2010).

8. Murphy, Political Imprisonment and the Irish.

9. Literature on this period is voluminous. For a detailed discussion of British policy and deteriorating Anglo-Irish relations, see Ronan Fanning, British Government and Irish Revolution 1910-1922 (London: Faber and Faber, 2013).

10. Michael Laffan, The Resurrection of Ireland: The Sinn Féin Party, 19161923 (Cambridge: Cambridge University Press, 1999), pp. 266-303.

11. For the Irish War of Independence, see, among others, Michael Hopkinson, The Irish War of Independence (Dublin: Gill and Macmillan, 2002). For discussion of IRA activities in this period, see Peter Hart, The IRA and its Enemies: Violence and Community in Cork, 1916-1923 (Oxford: Clarendon Press, 1998) and Peter Hart, The IRA at War, 1916-1923 (Oxford: Oxford University Press, 2003).

12. Michael Hopkinson, Green against Green: A History of the Irish Civil War (Dublin: Gill and Macmillan, 1988).

13. Biggs, 'The Rationality of Self-Inflicted Sufferings', p. 3.

14. BMH Witness Statement 355, Joseph Furlong, p. 12.

15. 'Frongoch Camp', House of Commons Debates (31 December 1916), vol. 88 cols $1604-5$.

16. Frank Gallagher, Days of Fear: Diary of a 1920s Hunger Striker (Dublin: Mercier Press, 2008 [1967]), p. 55.

17. See, for instance, the discussion in 'Prisoners on Hunger Strike', Dáil Éireann Debates (17 April 1923), vol. 3, no. 3, cols 190-6.

18. James Healy, 'The Civil War Hunger Strike: October 1923', Studies: An Irish Quarterly Review, 71 (1982), pp. 213-26 on p. 214.

19. 'Dublin Suffragist Prisoners: Letter from Mr Bernard Shaw', Irish Times (17 September 1912), p. 7.

20. Ibid., p. 7.

21. Public Record Office of Northern Ireland (hereafter PRONI), $\mathrm{CAB} / 8 \mathrm{G} / 26$, 'Agenda for Cabinet Meeting: Report by Major Long, Governor of Belfast Prison', 31 October 1923.

22. Biggs, 'Rationality of Self-Inflicted Suffering', p. 5. 
23. 'Sinn Féin Prisoners', King's Co. Independent (29 September 1917), p. 5

24. NAI, GPB/1917/Folder 2, 'Proceedings of a Board Assembled at Mountjoy Prison on the 29 September 1917 by order of G. O. C. in Chief of the Forces in Ireland for the Purpose of Examining and Reporting upon the State of Health of Certain Prisoners who have been on Hunger Strike for Several Days', 29 September 1917.

25. NAI, GPB/1918/Folder 2, 'Memorandum in Reference to the Practice of the Abandonment of Forcible Feeding of Prisoners in Ireland', 9 November 1918.

26. 'Mountjoy Prison (Forcible Feeding)', House of Commons Debates (23 January 1918), vol. 101 cols 1008-9.

27. NAI, GPB/1918/Folder 2, 'Daily Reports on Prisoners on Hunger Strike: Edward Horgan', January 1918; NAI GPB/1918/Folder 2, 'Daily Reports on Prisoners on Hunger Strike: James Roche', January 1918.

28. NAI, GPB 1918/Folder 2, 'Letter from Joseph O'Carroll to Dublin Castle', 23 January 1918.

29. 'Hunger Strikers Free: Effects of Forcible Feeding', Irish Independent (25 January 1918), p. 2.

30. NAI, GPB 1918/Folder 2, 'Letter from Dr Dowdall to General Prisons Board', 28 January 1918.

31. BMH Witness Statement 1415, Michael Hartney, p. 6.

32. 'Limerick Doctor and Forcible Feeding: Guardians and Dispensary Appointment', Irish Times (2 April 1919), p. 6.

33. 'Hunger Strikers Dying: Are They being Forcibly Fed?', Cork Examiner (19 August 1920), p. 3.

34. BMH Witness Statement 517, Maurice Crowe, p. 8.

35. See, for instance, the discussion on force-feeding in 'Death of Thomas Ashe', House of Commons Debates (15 November 1917), vol. 99 cols 561-2561.

36. NAI, GPB/1919/7248, 'Letter from C. A. Monro to General Prisons Board', 14 October 1919.

37. NAI, GPB/1918/Folder 2, 'Memorandum in Reference to the Practice of the Abandonment of Forcible Feeding of Prisoners In Ireland', 9 November 1918.

38. NAI, S14059, 'Letter from John Irwin to Mr. Duke', 7 March 1918.

39. NAI, GPB/SFRG/1/33, 'Letter from Joseph O'Carroll to Edgar Flinn', 17 August 1912.

40. BMH Witness Statement 1474, Eamon O'Dwyer, pp. 26-7.

41. NAI, 'Memorandum in Reference to the Practice of the Abandonment of Forcible Feeding of Prisoners in Ireland'. 
42. Gallagher, Days of Fear, p. 59.

43. NAI, GPB/1918/Folder 2, 'Telephone Message: J. F. Devane to General Prisons Board', 7 February 1918.

44. NAI, GPB/1920/144, 'Government Minute with Copy of Attorney General's Opinion as to the Duty of Prison Officials in relation to Prisoners who voluntarily Abstain from Food', 9 January 1920.

45. NAI/GPB/1920, 'Letter from the Competent Military Authorities to the Governor of Cork Male Prison', 9 January 1920.

46. NAI, GPB/1920/144, 'Letter from J. Iding to General Prisons Board', 6 January 1920.

47. NAI, GPB/1920/144, 'Telegram from Governor of Cork Prison to General Prisons Board', 10 January 1920.

48. NAI, GPB/1920/5175, 'Memo from Cork Prison to General Prisons Board', 14 June 1920.

49. NAI, GPB/1920/5175, 'Memo: General Prisons Board for Ireland', 14 June 1920.

50. Gallagher, Days of Fear.

51. Alannah Tomkins, 'Workhouse Medical Care from Working-Class Autobiographies, 1750-1834', in Jonathan Reinarz and Leonard Schwarz (eds), Medicine and the Workhouse (Rochester, N. Y.: University of Rochester Press, 2013), pp. 86-102 on p. 88.

52. Biggs, 'The Rationality of Self-Inflicted Suffering', p. 11.

53. See Graham Walker, “The Irish Dr Goebbels': Frank Gallagher and Irish Republican Propaganda', Journal of Contemporary History, 27:1 (January 1992), pp. 149-65.

54. BMH Witness Statement 517, Maurice Crowe, p. 1.

55. BMH Witness Statement 671, Patrick Rankin, p. 16.

56. BMH Witness Statement 1702, Seán O’Carroll, pp. 15-16.

57. BMH Witness Statement 671, Patrick Rankin, p. 15.

58. Francis Gano Benedict, A Study of Prolonged Fasting (Washington D. C.: Carnegie Institute of Washington, 1915).

59. See Miller, Modern History of the Stomach, pp. 57-80.

60. For an overview of the history of scientific investigations into starvation in this period, see Kevin Grant, 'Fearing the Danger Point: The Study and Treatment of Human Starvation in the United Kingdom and India, c.1880-1974', in Marshall D. McCue (ed.), Comparative Physiology of Fasting, Starvation and Food Limitation (Berlin and New York: Springer, 2012), pp. 365-78.

61. Peter R. Kerndt, James L. Naughton, Charles E. Driscoll and David A. Loxterkamp, 'Fasting: The History, Pathophysiology and Complications', Western Journal of Medicine, 137:5 (November 1982), pp. 379-99 on p. 396. 
62. Kerndt, Naughton, Driscoll and Loxterkamp, 'Fasting', p. 383.

63. PRONI, D4131/K/79, 'Letter from Constance Markievicz from North Dublin Internment Camp to Unknown Recipient', 1923.

64. Gallagher, Days of Fear, p. 75.

65. BMH Witness Statement 836, Seán Moylan, pp. 68-9.

66. For an extended discussion of time and imprisonment, see Alyson Brown, English Society and the Prison: Time, Culture and Politics in the Development of the Modern Prison (Woodbridge: Boydell, 2003).

67. Miller, Reforming Food in Post-Famine Ireland, pp. 74-8; Miller, 'Food, Medicine and Institutional Life'.

68. Gallagher, Days of Fear, p. 21.

69. Ibid., p. 39.

70. BMH Witness Statement 1135, William McNamara, p. 16.

71. BMH Witness Statement 779, Robert Brennan, p. 421.

72. BMH Witness Statement 779, Robert Brennan, p. 416.

73. BMH Witness Statement 836, Sean Moylan, p. 70.

74. BMH Witness Statement 1093, Thomas Treacy, p. 61.

75. Albert Coyle, Evidence on Conditions in Ireland Comprising the Complete Testimony, Affidavits and Exhibits Presented before the American Commission on Conditions in Ireland (Washington D. C.: Bliss Building, 1921), pp. 24-5.

76. BMH Witness Statement 671, Patrick Rankin, pp. 15-16.

77. BMH Witness Statement 802, Sean Prendergast, pp. 132-6.

78. Ibid., pp. 139-40.

79. Fessler, 'Implications of Starvation Induced Psychological Changes', p. 244.

80. Gallagher, Days of Fear, p. 39.

81. Fessler, 'The Implications of Starvation Induced Psychological Changes', p. 246.

82. Gallagher, Days of Fear, pp. 69-70.

83. 'Hunger Strikes: Understanding the Underlying Physiology will Help Doctors Provide Proper Advice', British Medical Journal, 315 (4 October 1997), pp. 829-30.

84. BMH Witness Statement 517, Maurice Crowe, p. 7.

85. NAI, GPB/1920/2169, 'Extract from the Visiting Committee's Minute Book', 15 April 1920.

86. NAI, S11369/9, 'Letter from M. H. O'Connor to Military Governor', 13 November 1922.

87. BMH Witness Statement 1393, Edmond McGrath, pp. 10-11.

88. 'Hunger Strikes: Understanding the Underlying Physiology', p. 830.

89. BMH Witness Statement 1135, William McNamara, p. 7. 
90. BMH Witness Statement 1702, Seán O’Carroll, p. 16.

91. BMH Witness Statement 671, Patrick Rankin, pp. 18-20.

92. BMH Witness Statement 802, Seán Prendergast, p. 147.

93. Ibid., pp. 153-5.

94. BMH Witness Statement 1209, Stephen Keys, p. 40.

95. Biggs, 'The Rationality of Self-Inflicted Suffering', p. 8.

96. BMH Witness Statement 1348, Michael Darven, pp. 34-5.

97. For more detailed analysis, see Murphy, Political Imprisonment and the Irish, pp. 174-92.

98. See Hannigan, Terence MacSwiney.

99. 'Twentieth Day of Hunger Strike', Cork Examiner (29 August 1920), p. 8 .

100. 'Cork Prisoners: All in Grave Condition', Cork Examiner (1 September $1920)$, p. 5.

101. 'Cork Prisoners: Two Collapse', Cork Examiner (3 September 1920), p. 4.

102. 'The Cork Prisoners: Twenty-Seventh Day without Food', Cork Examiner (6 September 1920), p. 5.

103. 'The Cork Prisoners: Twenty-Seventh Day without Food', Cork Examiner (6 September 1920), p. 5.

104. University College Dublin (hereafter UCD) archives, MS 8446/1, 'Daily Reports on Terence MacSwiney's Health', 1920.

105. 'Cork Prisoners: Visited by Bishop of Cork', Cork Examiner (13 September 1920), p. 5.

106. 'Cork Prisoners: Still Alive and Determined', Cork Examiner (15 September 1920), p. 5.

107. 'Cork Prisoners: Military Inquiry Over', Cork Examiner (16 September $1920)$, p. 5.

108. William Murphy, 'Dying, Death and Hunger Strike: Cork and Brixton, 1920', in James Kelly and Mary Ann Lyons (eds), Death and Dying in Ireland, Britain and Europe: Historical Perspectives (Dublin: Irish Academic Press, 2013), pp. 297-316 on p. 297.

109. 'The Hunger Strikers', Cork Examiner (24 September 1920), p. 4.

110. UCD archives, MS 8446/1, 'Daily Reports on Terence MacSwiney's Health'.

111. Vernon, Hunger, p. 77.

112. Quoted in 'Abstinence from Food: Causes of Endurance', Cork Examiner (7 October 1920), p. 6.

113. 'The Cork Prisoners: Forty-Eight Days Fast: Interview with Doctors', Cork Examiner (27 September 1920), p. 6.

114. UCD, MS 8446/1, 'Daily Reports on Terence MacSwiney's Health'. 
115. UCD, MS 8446/1, 'Daily Reports on Terence MacSwiney's Health'. 116. 'The First Death', Cork Examiner (12 October 1920), p. 5.

117. 'Another Death at Cork Gaol', Cork Examiner (26 October 1920), p. 4.

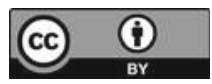

This chapter is distributed under the terms of the Creative Commons Attribution 4.0 International License (http://creativecommons.org/ licenses/by/4.0/), which permits use, duplication, adaptation, distribution and reproduction in any medium or format, as long as you give appropriate credit to the original author(s) and the source, provide a link to the Creative Commons license and indicate if changes were made.

The images or other third party material in this chapter are included in the work's Creative Commons license, unless indicated otherwise in the credit line; if such material is not included in the work's Creative Commons license and the respective action is not permitted by statutory regulation, users will need to obtain permission from the license holder to duplicate, adapt or reproduce the material. 


\section{'I've Heard o' Food Queues, but This Is the First Time I've Ever Heard of a Feeding Queue!': Hunger Strikers, War, and the State, 1914-61}

During wars and conflicts, state bodies can assume unprecedented levels of power. By declaring states of emergency under the aegis of protecting their citizens, governments can acquire discretionary powers that impinge upon personal privacy, resort to actions that would normally be deemed unacceptable during peace-time and allow political opponents to be detained, often without trial. ${ }^{1}$ Inevitably, this works unfavourably for politicised prisoners. War breeds hatred and contempt which is often reflected in severe institutional treatment. In such circumstances, hunger striking can be exceptionally common. Physical and emotional violence suffered in prisons encourages a desire to reassert bodily autonomy. In turn, the broader context of war allows governments to reaffirm their conviction that hunger strikers form part of a group that poses a threat to socio-political order. In wartime, hunger striking takes place in the face of powerful discourses on the danger seemingly posed by political dissidents to the safety of the nation. Acts such as force-feeding help to reinforce the sovereignty of the state on a physical and metaphorical level. When performing the procedure, prison doctors help to re-establish prison order but also overtly contribute to the broader political project of protecting national security. To worsen matters even further for hunger strikers, media coverage can be censored, interpersonal violence can be justified by the exigencies of war, and prisoners can be easily denounced as enemies of the state at times of patriotic fervour. In a frenzy of panic over 'terror' and enemy threats, the public is discouraged from caring about the plight of disruptive prisoners. 
This chapter focuses on the experiences of conscientious objectors in First World War England. After 1917, force-feeding was no longer resorted to in Ireland. However, force-feeding policies remained in place in England. During the First World War, politicised prisoners, while hunger striking, were exposed to harrowing levels of institutional violence and brutality. Their subversive ideas seemed to threaten national order, a problem that bred contempt between staff and prisoners. Conscientious objectors sought peace in an era of heightened patriotism.

Somewhat paradoxically, wartime hunger strikers are often adept at drawing public attention to unacceptable institutional conditions. While imprisoned, politicised prisoners can do little to challenge the government that has incarcerated them. But wars end and opportunities arise to speak out. This was certainly the case for First World War conscientious objectors. In the 1920s, exposure to disproportionate violence and suffering encouraged many of them to campaign for prison reform. Some brought considerable change to the prison system. Deaths from starvation and brutal force-feedings buttressed the broader claim that early twentieth-century prisons were beset with problems; that the disciplinary functions of these sites were excessive and unjust. Prisons, by their very nature, are enigmatic sites. The disciplinary regimes enacted within them on the bodies of prisoners are mostly hidden from public view. However, politicised prisoners are often skilled at gathering support for prisoner welfare concerns. Upon release, they prove remarkably vocal about their institutional experiences. As Martin J. Weiner suggests, politicised prisoners tend to feel extremely alienated from authority and are particularly sensitive to mistreatment. Many are highly articulate. ${ }^{2}$ They are able to convey details of prison life in a way that the majority of convict prisoners cannot. Many are educated and communicate their memories eloquently and fluently. Through their writings and campaigning, they bring to light conditions that normally remain hidden from public view. In turn, tales of excessive suffering jar with public sensitivities towards pain and torture, sparking debate about governmental support of dismal institutional conditions, unethical behaviour, and inhumane treatment. The rational political logic of protecting national security can certainly lend support to mass internment or wartime imprisonment, as well as the claim that hunger strikers inflict death upon themselves. But, the emotional economies of western societies provide a counterbalance. Suffering, after all, is something which the barbaric enemy supposedly enacts. It holds no place in a society battling to maintain its values of humanity and decency. When 
investigating the relationship between governments and hunger strikers, historians have regularly outlined the complexities of political manoeuvrings. ${ }^{3}$ However hunger strikes have rarely been contextualised in relation to ideas about the body, pain, and emotions. A distinct emotional script exists in the public sphere that counters the rational logic adopted by governments in tackling hunger strikes at times of crisis, a world of feeling that condemns actions such as force-feeding that seem to contradict western sensibilities on suffering. ${ }^{4}$

In recent years, an outflowing of best-selling autobiographical literature from released Guantánamo detainees testifies to the high interest in the plight of prisoners considered to be treated unfairly during the "war on terror'. ${ }^{5}$ Hunger strikers find ways to publicly challenge the governments that mistreat them. While support for radical religious extremism is limited in the west, enthusiasm for anti-terror measures and military intervention in Islamic countries is far from universal. A humanitarian narrative exists that has called into question the capacity of the state to detain individuals and use doctors to force-feed. An inherent tension exists between the rational political logic of imposing punishment at times of crisis to help maintain socio-political order and the emotions involved in sympathising with prisoners imagined to be in pain. Indeed, the stories told by released Guantánamo detainees have inspired considerable opposition to the feeding methods currently being used in the name of the 'war on terror'. ${ }^{6}$

\section{Force-Feeding Conscientious Objectors}

During the First World War, large numbers of conscientious objectors refused to fight. In Britain, many accepted civilian work or service in noncombatant Corps. A small, but vocal, group of absolutists refused to compromise. These individuals had been conscripted and classified as soldiers but refused to perform military service. They found themselves in a recurrent cycle of being court-martialled, imprisoned, and released. While in prison, they disobeyed institutional rules on the grounds of conscience and, emulating militant suffragettes and Irish republicans, actively sought to undermine the prison system. ${ }^{7}$ David Boulton estimates that, in total, 1543 conscientious objectors served sentences in English prisons. ${ }^{8}$ While incarcerated, they faced extraordinary levels of contempt and physical violence. They had objected to conflict at a time when the state and much of the population supported war. Their harshest critics dismissively portrayed them as degenerate, effeminate, and unhealthy, not to mention inherently 
dangerous. Their refusal to fight threatened to jeopardise the national war effort. ${ }^{9}$

Faced with antagonism, violence, and deplorable living conditions, many conscientious objectors went on hunger strike. Prison doctors forcefed them brutally. A considerable number of hunger strikers quickly capitulated. When Wandsworth Prison's medical officer, James Pitcairn, tried to feed one conscientious objector, the stomach tube 'proved disagreeable'. Writhing in pain, the prisoner swiftly resumed eating. ${ }^{10}$ Nonetheless, others unwaveringly endured remarkably long periods of being fed against their will. In 1917, Joseph Garstand was force-fed for thirteen days. In the same year, J.W. Illingworth endured forty-five days of being fed in Birmingham. Between 1917 and 1918, prison doctors fed Frank Higgins twenty-two times in Newcastle, followed by a longer period of sixty-three days. ${ }^{11}$ The infliction of suffering upon men with peaceful, pacifistic tendencies aroused an emotional public response, demonstrating that public sensibilities towards needless violence could co-exist with support for the war effort. Although intense animosity was felt towards men who refused to fight, a perceptible unease emerged towards using excessive force on peaceful prisoners. The exigencies of war provided state bodies and prison officials with a rationale for supporting, or turning a blind eye to, physical and psychological intimidation, particularly when directed at seemingly contemptuous individuals. However prisons were no longer meant to be sites of pain, violence, and brutality. In theory, prisons were now intended to rehabilitate, not engage in relentless disciplining.

In light of this conflicting opinion, the plight of conscientious objectors attracted the attention of sections of left-wing newspapers, most notably those which had denounced force-feeding during the recent suffragette hunger strike campaign. Circumventing wartime censorship, the Manchester Guardian regularly published (necessarily objective) reports on the predicament of conscientious objectors such as Manchester silver engraver, Emmanuel Ribeiro. In January 1917, Emmanuel was courtmartialled for refusing to undertake military service. He found himself removed to military barracks in Bury where he went on hunger strike. Emmanuel was then transported to a military hospital in nearby Warrington and force-fed for seventeen months. Six months into Emmanuel's feedings, James MacPherson, Under-Secretary of State for War, stated in the House of Commons that Emmanuel was not resisting the prison doctors. The feedings were in no way 'forceful', he suggested, because Emmanuel was compliant. ${ }^{12}$ Contradictory accounts, published in the Manchester 
Guardian, suggested that Emmanuel's feedings were in fact painful and deeply degrading. In July, Constance Lytton contacted Emmanuel's wife asking if he had sent any personal accounts from the prison. Emmanuel had. In these, he claimed that he had actively resisted the prison doctors for the first three months. He wrote:

They force a gag into my mouth which causes terrible pain. Then a tube was put in the mouth and forced into my stomach ... with six men holding me down from moving. On Tuesday... I resisted after falling on the ground; they, with all hands holding me on the ground, forcibly-fed me there. This I say is scandalous. It is not only inhuman but barbarous torture of the worst kind.

In his mournful letters, Emmanuel portrayed a system of institutional intimidation intent on violently ending his protest. He portrayed forcefeeding as a daunting encounter with a vast network of medical, institutional, and military power determined to bring his errant behaviour (or viewpoints) into line by forcing food into his gullet. Emily Lutyens, Lytton's sister, argued in the Manchester Guardian that 'apart from the question of humanity, it would seem to be a waste of the manhood of the nation in this time of war to employ six able-bodied men to torture one defenceless man. ${ }^{13}$ But using military manpower to undermine a protest undertaken by a single individual served symbolic purposes. Exerting power and authority over one conscientious objector allowed the state to make visible its determination to maintain social and institutional order, uphold the authority of its conscription Acts, and deter like-minded individuals from refusing to fight. It set a strong example to others on the need for national solidarity at a time of international crisis.

In February 1918, a friend obtained permission to visit Emmanuel. By this stage, Emmanuel had been force-fed for thirteen months. He reported to the Manchester Guardian that:

Ribeiro was forcibly-fed during our visit but we were not allowed to witness the process, although we saw the tube brought in. It was over in a few minutes, and when we returned he was ill and giddy from the effect of the treatment. He was evidently suffering with very strong movements of the heart. He pressed his hand hard on his left breast, seemed pale and exhausted, and for a time could only speak with difficulty ... I consider that the condition of Ribeiro is alarming, his health being much worse than when I last saw him. I fear he will die if not quickly liberated. 
This statement encouraged readers to empathise with Emmanuel by detailing a gradual breakdown brought on by having a stomach tube involuntarily forced deep into his body. Force-feeding was portrayed as physically and emotionally exhausting; as a procedure that debilitated, rather than restored, the health of starving prisoners. On the basis of this account, conscientious objector, physician, and Labour politician, Alfred Salter, asserted that 'the authorities know that he will never be in a fit state of health to be court-martialled yet still they continue their persecution of him rather than discharge him. ${ }^{14}$ Five months later, the Manchester Guardian subtly reported that 'Emmanuel Ribeiro, the Manchester conscientious objector, who has been on hunger-strike for seventeen months, has been released from Wormwood Scrubs Prison owing to the serious condition of his health', adding that 'it was time'. ${ }^{15}$ Emmanuel's force-feeding was an overtly political act supported by a wartime state that clashed with public sensitivities towards pain, medical ethics, and institutional norms. However objectionable refusing to fight might have seemed, performing force-feeding for over a year appeared morally problematic and somewhat futile. If anything, it seemed to highlight the state's inherent vindictiveness. For such reasons, Emmanuel amassed support from eminent individuals, including Constance Lytton. The ethical discussion that ensued about Emmanuel's force-feeding shared similarities with earlier debates on the plight of hunger striking suffragettes. Yet the broader context of war in which conscientious objectors staged hunger strikes meant greater exposure to antagonism, resentment, hostility, and violence. The force-fed body of a male conscientious objector held less political currency than that of a female suffragette body, particularly when damage and harm had been inflicted upon it to support the popular wartime cause.

The experiences of other conscientious objectors held in military prisons further demonstrate that war amplified the viciousness of prison encounters. In 1917, conscientious objector, Clarence Henry Norman, prosecuted Lieutenant Reginald Brooke for unlawful assault. The Manchester Guardian reported on the proceedings. Henry alleged that he had been spat on, placed in a strait-jacket, verbally abused, and force-fed at Wandsworth Detention Barracks. He had initially been detained for refusing to submit to a medical examination or put on a military uniform. The lieutenant defended his belligerence by claiming that he had no option but to place Henry in a strait-jacket. The prisoner was clearly suicidal, having announced his intention to die from hunger and thirst. During his multiple feedings, Brooke aggressively yelled 'coward', 'swine', 'beast', 
and 'sham conscientious objector'. Verbal abuse had been necessary, the lieutenant insisted, as Henry was a coward, not a conscientious objector. He fully deserved every word of the strong language uttered to him. ${ }^{16}$

In the following year, another conscientious objector, imprisoned at Newcastle, was reportedly forced to his cell floor and held down by several officers to have a feeding tube forced through his nose so violently that it caused intense bleeding. The prison doctor sat laughing at the prisoner, taunting him by imitating his moans and cries. The incident was discussed in the House of Commons. ${ }^{17}$ The few accounts that entered the public domain demonstrate the extremities of violence directed towards hunger striking conscientious objectors. War could be used to justify verbal intimidation, unwarranted intrusions in the inner body, and psychological humiliation. Conscientious objectors were made to suffer as they posed a national threat. Such assaults embodied the exertion of sovereign power onto the bodies of those deemed too cowardly to fight.

Even death was of little consequence. Censorship could be used to hide details from the public; prison doctors could deny responsibility while feeling little remorse over the death of a traitor to the nation. The passing away of a conscientious objector did not carry the same emotional meanings in wartime England as Thomas Ashe's death had done in revolutionary Ireland. In England, pacifists were cast as cowards, not heroes. In 1918, a conscientious objector named William Edward Burns passed away in Hull Prison after a bout of force-feeding. An inquiry was overseen by prominent surgeon and bacteriologist, William Watson Cheyne, and Guy's Hospital physician Maurice Craig. Notably, Craig had been called upon by the Home Office during the trial of Leigh $v$ Gladstone where he had openly supported the official line on 'artificial feeding' as safe, necessary, and therapeutic. ${ }^{18}$ His appointment at this inquiry was hardly impartial. At the inquiry, it transpired that William had gone on hunger strike to protest against receiving inadequate medical attention and to obtain a transfer (by weakening himself) to a nearby nursing home. The prison doctor, Dr Howlett, admitted that he had noted Burns' anaemic appearance but had decided that all conscientious objectors suffered from the condition. 'They are anaemic in their brains', he caustically added. Howlett admitted that William had regularly complained to him about his weak legs and general physical debility. ${ }^{19}$ Yet Howlett had considered William's leg reflexes to be normal. Defending his decision to intercept a letter sent by Burns' to his wife, the prison governor insisted that William had made exaggerated claims about his poor health, adding that letters 
were not allowed to leave the prison that might alarm relatives and friends. Accordingly, the governor had ordered William to re-write his letter to provide a more accurate account about his health. At this point, William bemoaned that he was falling to pieces.

As a last resort, William went on hunger strike. During the forcefeedings that ensued, William does not appear to have resisted the stomach tube, although he did audaciously question whether Howlett had the permission of the Home Secretary. William was fed two pints of milk and cocoa through a stomach tube. During his second feeding, he began to spasm, splutter, and regurgitate his food. After the prisoner had settled down, Howlett continued his work. The following morning, William awoke with an alarmingly high temperature of $101{ }^{\circ} \mathrm{F}$ and a sharp pain in his side. Fearing that William had contracted pneumonia, Howlett removed William to a hospital cell and continued to force-feed him twice a day until he eventually died. The inquiry brought to light the fact that Howlett had never performed force-feeding before. Cheyne remained somewhat sceptical of Howlett's suggestion that the 'blood-stained frothy stuff' which Burns had coughed up was 'the sticky stuff of pneumonia'. Instead, he suggested, Howlett had noted globules of milk that, due to the excessive quantity of food being inserted into the stomach tube, had remained in William's lungs for a number of days. ${ }^{20}$ Notwithstanding this suggestion, Craig and Cheyne concurred that William had died from pneumonia, a condition worsened by inhaling fluid food while being fed. No blame was attributed to Howlett. ${ }^{21}$ In the House of Commons, Home Secretary George Cave reported that artificial feeding had been necessary and that William's death could not be attributed to a lack of care or skill on the part of the medical officer. ${ }^{22}$

William's plight highlights the anger felt by medical staff towards prisoners who challenged the state during wartime, the consequences being a lack of therapeutic care and an eagerness to inflict violence. Not even death could bring out remorse or compassion from the military doctors who force-fed. Howlett was too antagonistic to William's steadfast belief in the futility of war. Ironically, in rejecting international violence, William found himself subject to state-supported violence. In the context of war, it seems likely that Howlett used force-feeding primarily to discipline and punish. It also seems probable that Emmanuel Ribeiro and Clarence Henry Norman experienced force-feeding as a coercive accompaniment to a retributive system in which sovereign power was articulated through beatings, restraint, and bodily intrusion. In the First World War, force-feeding 
was used as part of a broader military complex which discouraged political dissent. Hunger strikers encountered inexperienced doctors and belligerent lieutenants who shared an agenda of helping to secure military victory. This over-ruled any moral objections which doctors might have otherwise had towards feeding pacifist prisoners against their will. Staff working within the military machine were undeniably aligned to the state, perhaps more so than prison doctors employed during the suffragette hunger strike campaign. They used force-feeding to violently punish those who failed to share their views on the need to support the national war effort.

\section{Twentieth-Century Peace Movements and Hunger STRIKING}

During war, governments are able to support methods of dealing with its opponents that would normally clash with accepted ethical behaviour. Employing prison doctors to force-feed is one example of how control is regained over the bodies of those who threaten state objectives. However politicised prisoners rarely forget their institutional experiences. They communicate their prison encounters in a range of narrative forms, most notably autobiography. Often, they bring to light occurrences that passed unnoticed until censorship is lifted. After the First World War ended, conscientious objectors initiated a robust campaign for prison reform. Leading members of the movement were articulate and determined, and they felt impassioned by their wartime incarceration. It is also likely that the unfamiliarity of conscientious objector prisoners to the normally secretive world of the prison enhanced the sense of revulsion felt towards institutional conditions. In the 1920 s, peace advocates were well placed to act as spokesmen for convict prisoners; a group who tended not to possess the means or ability to convey details of English prison conditions to the general public. Most notably, Stephen Hobhouse was invited by prominent social reformer, Beatrice Webb, to lead a Prison System Enquiry Committee that included Lord Olivier, the former governor of Jamaica, and George Bernard Shaw. The results were published in the comprehensive English Prisons Today in 1922. ${ }^{23}$ They initiated a wave of prison reform that has continued to this day.

Calls for prison reform were buttressed by emotive texts and pamphlets penned by former conscientious objectors. Since the late nineteenth century, middle-class individuals such as the anonymous author of Five Years Penal Servitude (1893) had penned memoirs that called attention to 
institutional problems that would have otherwise gone unnoticed. ${ }^{24}$ In the interwar period, conscientious objectors embraced this tradition by penning a considerable amount of autobiographical literature that highlighted the physical and psychological experiences of wartime imprisonment. In his Prisoners of Hope, published in 1918, Charles S. Peake claimed that, while imprisoned, prisoners of conscience had fatally contracted pneumonia, been removed to lunatic asylums despite being mentally sound, died from severe malnutrition and, in some instances, committed suicide. ${ }^{25}$ Hunger striking and force-feeding loomed large in their accounts. The ongoing incarceration of conscientious objectors long after the end of war retained a prominent place in memories of war. In March 1919, Colonel Wedgewood rallied in the House of Commons against the ongoing imprisonment of conscientious objectors and excessive use of forcefeeding, lamenting that 'we are now forcibly-feeding more men in prison than were forcibly-fed during the whole of the women's agitation and when it is realised that these people are being unjustly kept in prison, that we should have that aggravated by forcible-feeding seems to me to be an atrocious commentary upon the administration of the criminal law in this country. ${ }^{26}$ Richard Michael Fox was among the conscientious objectors who took part in the mass hunger strikes of 1919. In his Drifting Men of 1930, published by Leonard and Virginia Woolf, Fox recollected his experiences as follows:

They were lined up and put one by one in a big chair where burly men in white overalls gripped their arms and legs, forcing their heads back. Each man had a wooden gag jammed roughly in his mouth. Through a hole in this a long rubber tube was worked down his throat. Every choking, suffocating breath only drew the tube further down till, with a sickening sensation, it reached the stomach. Milk food was then poured in through a funnel. A hunger striker from Wigan commented with grim humour, "well I've heard o' food queues, but this is the first time I've ever heard of a feeding queue!”. One man, looking very ill, his face greenish-white, was being pushed round the exercise yard by the two guards. As he fainted and collapsed he was picked up by his head, lifted to his feet and gently urged on. It was all done so deliberately, so quietly and so decorously. He was not allowed to rest for a moment. Hunger strikers were immediately moved into the dungeons-dirty, dark, half-underground cells calculated to induce depression and increase mental torture. ${ }^{27}$ 
Fox added that:

Forcible-feeding, with its assault on personality-the white-smocked doctor, his uniformed assistants, his paraphernalia of rubber tube, gag and funnel, all mobilised to defeat the will of the prisoner-is a horrible business. I do not think there are many prisoners who have entered on a hunger strike, who would not prefer to starve to death rather than submit to this mauling, especially as after the first two days the ravenous desire for food vanishes. By staking their lives on the issue, the hunger strikers helped to force an inquiry into the conduct of the prison. ${ }^{28}$

Although it actively campaigned for prison reform, the pacifist movement was unable to end prison force-feeding. Throughout the Cold War, peace protestors continued to challenge the government by staging hunger strikes. In 1959, John Francis Otter and Philip Cook, members of the Direct Action Committee against Nuclear War, went on hunger strike in Norwich while imprisoned for protesting outside a rocket site at Swaffham..$^{29}$ In 1962 , Committee of Hundred members, Helen Allegranza, staged a forty-eighthour fast in Holloway to remonstrate against Britain's resumption of nuclear tests. ${ }^{30}$ In the same year, senior aircraftman, Brian McGee, disobeyed military instructions in sympathy with the campaign for nuclear disarmament. He found himself imprisoned at the Colchester Military Corrective Training Establishment where he also went on hunger strike. ${ }^{31}$

Many Cold War peace protestors were force-fed. Their relatively high public profile ensured that their protests attracted media interest. Pacifists still formed part of a broader supportive community who could draw attention to matters such as unfavourable prison treatment. Perhaps, the most prominent anti-nuclear war protestor to go on hunger strike was Pat Arrowsmith. Pat was an educated middle-class peace campaigner who ultimately served eleven prison sentences for her political activities and even took the British government to court for alleged breaches of human rights. In 1961, Pat refused food in Gateside Prison, Greenock, to protest against being made to sew canvas bags intended for use as sandbags. Prison doctors force-fed Pat four times. Pat resolutely believed in nonviolent resistance and decided not to physically resist her doctors. The Daily Express reported Pat's mother to have said 'I have telephoned the prison and sent her a verbal message that this action of hers is foolish and oversteps the mark. If she was forced to make bullets I would have every 
sympathy for her but in the circumstances I think she is going too far. ${ }^{32}$ Pat resumed eating after four days. In the House of Commons, Labour politician, Emrys Hughes, pointed out that force-feeding had been performed before the prisoner had displayed any signs of health deterioration from hunger. 'Is he [John Maclay, Secretary of State for Scotland] aware that there are still in this country suffragettes who recall with horror experiences of this kind in prison?', Hughes asserted, 'is it not time that he took a definite line to stop this?'33

It later transpired that sewing sandbags had not actually been compulsory, although Pat later claimed that prison staff had failed to clarify this while she was hunger striking. In The Guardian, Labour politician, Judith Hart, asserted that the Scottish Home Department's 'insistence that the tube-feeding to which Miss Arrowsmith was subjected was 'artificial feeding' and not 'forcible feeding' is absurd; it is only because Miss Arrowsmith did not resist that the feeding was not 'forcible'. ${ }^{34}$ Emrys Hughes also wrote to The Guardian querying why prison doctors had felt a need to feed Pat 'artificially' before her hunger strike had started to endanger her health? Refuting suggestions that force-feeding was not a violent act when performed on a compliant patient, Hughes retorted 'but it does not follow from this that, while she was waiting for this twice-aday operation in the solitude of her cell, she did not suffer considerable strain and mental suffering knowing what was to come. Your view of this of course depends on what end of the rubber tube you are. ${ }^{35}$ Adding to the debate, Owen Staley suggested that Pat's force-feeding was an effort to break the emotional will of a courageous, principled woman. ${ }^{36}$ Not all letters published in The Guardian were entirely supportive. One read: 'Even the most convinced pacifist must admit that a sandbag, in so far as it is a military weapon, is a very inoffensive one. Many a life has been saved by a sandbag but I never heard of one being taken by it. ${ }^{37}$ Yet most contributors took issue with the seemingly excessive punitive techniques being deployed in English prisons to tackle individuals whose ideas ran against the grain of contemporary public thought on war and peace.

In 1971, Pat reflected on her experiences of being force-fed in The Guardian. She recalled:

I decided to go on hunger strike because prisoners were being made to work on sandbags and CND was then campaigning against civil defence. I wanted to take some action and what else can you do but refuse to eat? To begin with I got a spell of solitary 'for inciting a riot' which is rather funny for a 
pacifist: no books except the Bible and that's quite a subversive book. For the first few days they just let me alone. The screws were quite nice. They'd come and chat me up. They were troubled about my not eating. Then a lady doctor appeared, a rather pinched sort of woman, and said "come now, can't go on like this". I'd already decided I'd better agree with whatever was said so I made agreeing noises. She said at the end of five days with no food I couldn't be thinking clearly and I said "yes, yes, quite likely". "You need help", she said. "My help", she said. Next, I was visited by a psychiatrist and had to talk about myself for half an hour, which is always gratifying. He tried to make out that I was muddled but he couldn't do much really. He was a member of Scottish CND himself.

Pat recounted that she was later visited by a second psychiatrist, once journalists began to cover the story. 'They had to cover themselves', Pat claimed, 'to see if I was going bonkers or not. Actually going without food was quite disagreeable; I like my food and all the things I'd ever read about hunger turned out to be wrong.' For Pat, the most traumatic aspect of being force-fed was waiting for the footsteps of the doctors in the corridor leading to her cell. Pat contrasted her experiences to earlier groups such as the suffragettes. As she suggested:

The suffragettes, for instance, weren't [pacifists]; they had to resist, bite and spit and that makes things much worse... They push this tube down your throat to your stomach, you soon get a sore throat, and pour in stuff like Benger's Food. The worst part is when they pull it up again. It's like vomiting and sometimes I did vomit. If you won't co-operate, they put it through your nose and that is very painful. And I think I'd have been much more frightened if I'd known then what I know now, that there's a fair chance of pushing the tube through from the oesophagus into the windpipe and killing you ... No one was particularly malevolent. Even the doctor said, "I'm not employed to do this, I'm supposed to cure people" and there was certainly relief all round when they had orders to stop. ${ }^{38}$

The force-feeding of politicised prisoners always served a political purpose; it helped to quell dissidence. Yet, as Pat's statements suggest, performing force-feeding on the body of a pacifist evoked a particular sense that excessive violence was being perpetrated on an individual with no aggressive intentions. The act seemed all the more belligerent when the state authorised its use on individuals with peaceful motivations for hunger striking. What seems clear is that force-feeding continued to be deployed in England as a weapon for tackling political dissidence at times 
of international crisis throughout the twentieth century. Indeed, war and conflict continued to provide discourses that helped to justify the use of force-feeding, even as punishment. During the First World War, imprisoned conscientious objectors were fed against their will despite an awareness that force-feeding could kill if performed carelessly. Wartime exigencies increased the levels of violence inflicted on prisoner groups deemed as enemies of the state and its military aims. Prison doctors and military staff treated conscientious objectors with contempt and disdain. Their scorn was reflected in deep levels of violence that marred prison experiences, including death, viscious beatings, prolonged feedings, and tubes being inserted so brutally that prisoners bled through their mouths. Politicised prisoners have complex interactions with the state. Convict prisoners tend not to have offended the state, other than having committed disruptive criminal acts. However pacifists actively oppose the state. The brutal treatment of conscientious objectors and peace protestors represented an overexertion of the power of a state intent on preserving national security, even if this did involve inflicting physical and emotional harm.

\section{Wartime Irish Hunger Strikes}

It is worth briefly outlining the contrasting manner by which the Irish state tackled its wartime hunger strikers in the absence of a force-feeding policy. The partition of Ireland remained a divisive issue long after the Irish Civil War. In the 1920s, the Cumann na nGaedheal government consolidated the new Irish state. ${ }^{39}$ A relatively small number of anti-Treaty IRA members remained determined to re-unite the island. Éamon de Valera's Fianna Fáil government, which came into power in 1932, initially acted congenially towards the IRA. Indeed, de Valera himself had been a key revolutionary figure. Upon coming to power as Taoiseach, he legalised the IRA and freed republican prisoners interned under the Cumann na nGaedhael administration. Yet tensions mounted throughout the 1930s. In 1936, de Valera outlawed the IRA after a controversial series of murders and shootings. ${ }^{40}$ Hostility peaked during the Emergency (the term used for the Second World War in neutral Ireland). Irish public feeling towards the IRA was mixed. Given that many of its members had fought valiantly for the cause of independence just two decades earlier, a degree of sympathy existed. Nonetheless, the IRA stepped up its violence as the Second World War commenced, incurring governmental wrath. ${ }^{41}$ The onset of war coincided with a renewed period of republican violence 
in both Britain and Ireland. Major British cities were bombed. Fianna Fáil implemented emergency legislation to tackle political subversion, the most penetrative of which was the Offences Against the State Act (1939). This established special criminal courts and increased garda (the Irish police force) power to prevent seditious activities. The Emergency Powers Amendment Act (1940) conferred additional powers, including extended powers to use capital punishment. ${ }^{42}$ Fianna Fáil justified these security policies by warning that the IRA was likely to collude with Nazi Germany, disrupt Anglo-Irish relations, and disturb Irish efforts to remain neutral. ${ }^{43}$

Like many wartime leaders, de Valera used imprisonment extensively to quell political opposition. Like the conscientious objectors before them, IRA members protested by hunger striking in a climate of media censorship, and heightened public concern about political dissidence. Furthermore, de Valera was anxious to maintain good relations with the wartime British government, encouraging him to pursue ruthless strategies of neutralising militant republicanism. ${ }^{44}$ In September 1939, de Valera appointed Gerald Boland as Minister of Justice, an IRA veteran who was steadfastly loyal to the Taoiseach and who took a hard-line stance against militant republicanism. After being swiftly rounded up and detained, a number of imprisoned republicans decided to refuse food. De Valera sternly warned that he would not grant concessions. The prisoners, de Valera insisted were pursuing a violent, subversive path against the wishes and desires of the Irish population. He mournfully added that responsibility for a prison death would rest solely with the hunger strikers themselves and not with a government who refused to give in to unreasonable demands. ${ }^{45}$ De Valera depicted the starvation of a hunger striker as a self-imposed, if undesirable, tragedy; as a consequence of the irrational behaviour of politically subversive individuals. War allowed him to do so. National security was central to de Valera's rhetoric. Yet under the layers of compassion that permeated de Valera's announcement rested a crucial opportunity to permanently deal with a violent, subversive group.

The imprisonment of republicans fighting for the moral cause of a united Ireland stimulated mixed emotions. Hunger striking was deeply entrenched in the Irish psyche as a morally just action, a last resort against political injustice. The strong republican credentials of many of the protestors presented an irreconcilable ideological quandary. In October 1939, Con Lehane, a solicitor and later co-founder of republican political party Clann na Poblachta, went on the first reported hunger and thirst strike of the Emergency to protest against his detainment at Arbour Hill military 
prison. ${ }^{46}$ Labour politician, William Norton, sardonically asked Boland in the Dáil: 'am I to understand that hunger strikes or thirst strikes of this nature which were right in 1922 and 1923 are wrong in 1939? ? $^{4}$ Norton's shrewd comment pointed to the deeply embedded positioning of hunger striking in the Irish national psyche. Despite endorsing some releases, de Valera maintained that he was still willing to let hunger strikers die if necessary. In November, eminent republican and prisoner rights campaigner, Madam Maude Gonne MacBride, wrote to the President of Ireland, Douglas Hyde, pleading with him to intervene in a hunger strike being staged by Patrick McGrath. As part of her impassioned appeal, MacBride reminded Hyde that Patrick still had an English bullet lodged in his chest received during the Easter Rising. The bullet had lodged too close to the heart to allow for safe surgical removal. MacBride also pointed out that Patrick had fought valiantly in the War of Independence. She emotively warned that if one of them is allowed to die it will create a bitterness which nothing will be able to repair and we have had bitterness enough in our country since 1921. ${ }^{48}$ Nonetheless, de Valera remained firm despite the crisis of conscience produced by the idea of allowing an eminent former comrade to die. ${ }^{49}$ Ultimately, the hunger strikers were released and conveyed to a nearby nursing home..$^{50}$

Patrick's premature released was a victory for Irish republicanism. Nonetheless, it ultimately had lasting implications for the IRA. On 23 December 1939, fifty IRA members raided the Irish army's ammunition store in the Magazine Fort, Phoenix Park, stealing over a million rounds of ammunition. The raid heightened public concern about IRA activity, clashing as it did with the broader context of international conflict. After the raid, garda officers arrested and detained a number of individuals. Patrick McGrath was one of the arrested men, causing de Valera to regret his earlier decision to release hunger strikers. ${ }^{51}$ Indeed, he faced severe criticism in the Dáil for having given way earlier to McGrath's protest. ${ }^{52}$ From hereon, de Valera refused to succumb to further pressure to authorise the release of hunger strikers. The raid also prompted Boland to swiftly implement the amended Emergency Powers Act.

As Eunan O'Halpin suggests, hunger strikes now stopped being an effective means of extracting concessions. What followed was a purposeful wartime clampdown on political subversion. ${ }^{53}$ In February 1940, Anthony D’Arcy, Seán 'Jack' McNeela, Tomas MacCurtain, Michael Traynor, Thomas Grogan, Jack Plunkett, and John Lyons went on hunger strike at Arbour Hill Internment Camp. ${ }^{54}$ The prisoners declared that, in the event 
of a death, successive prisoner groups would pursue hunger strikes and take up the fight. ${ }^{55}$ Michael Traynor later recalled that 'day followed day. I cannot remember any particular incident, except that regularly three times a day an orderly arrived with our food, which we of course refused to take. We were by now nursing our strength realising that this was a grim struggle, a struggle to the death. We jokingly made forecasts of who would be the first to die.' Notably, Michael recounted that the prison medical staff, as is often the case in incidences of prison self-starvation, remained mostly sympathetic and accorded the protestors kind, humane treatment. ${ }^{56}$

Jack Plunkett was the brother of Joseph Plunkett, one of the executed leaders of the Easter Rising. In March 1940, his mother, Josephine Mary, wrote to Cardinal Joseph McRory pleading for his intervention. She steeped her letter with allegations of rampant immorality in convict prisons. Republican prisoners, she claimed, including a young seventeenyear-old, were imprisoned in Mountjoy alongside sexual degenerates, a tacit reference to the potential exposure of prisoners to homosexuality. ${ }^{57}$ Maud Gonne MacBride also wrote to McRory. As an active campaigner for improvement in Irish prison conditions, she framed her letter in terms of the cruelty of prison life and the harsh, demeaning rules in place that structured prison life. She claimed that 'non-recognition of political status leads to endless trouble, confusion and often to tragedy.' To fortify her point, she wrote:

So we have men like Jack Plunkett—whose family, God knows, have made sacrifices for Ireland which should have spared them this new torment-on hunger strike for sixteen days and people wondering how long they will last... none of these distressing things would have occurred if the prison code laid down recognition for political status. Is it necessary that another prisoner should die or another prisoner have to be transferred to a lunatic asylum before the prison code is altered to recognise political status? ${ }^{58}$

Nonetheless, sympathy towards the hunger strikers remained confined mostly to committed republicans. While the Lord Mayor of Dublin, Caitlin Bean ní Cléirigh, publicly conceded in March that 'it is sad to think that the brother of Joseph Plunkett is on hunger strike at Arbour Hill while preparations are being made to honour the memory of the Easter week leaders,' he added that 'it is sadder still to think that the uprising of 1916 against a foreign enemy should be so distorted as to be used as an excuse for condoning armed attacks on our people.' While acknowledging Plunkett's 
irrefutable republican credentials, ní Cléirigh portrayed the remaining IRA as a group of individuals who misunderstood the true nature of the War of Independence and the Civil War. ${ }^{59}$ Ultimately, the dilemma of allowing hunger strikers to starve even despite their close connections to national heroes of an earlier generation failed to weaken de Valera's resolve. While removing a small group of prisoners from prison to an internment camp appeared, on the surface, to be a somewhat trifling demand, the symbolic implications of acknowledging the IRA's political and military status, fortified with concern that further IRA internees might stage protests, remained omnipresent. In this instance, the state firmly maintained its sovereign right to maintain control over the prison environment. Moreover, the death of a hunger striker would present a stark warning to other potential protestors that national security interests needed to take precedence over IRA deaths for the foreseeable future.

When two deaths did occur, the attitudes of even hard-liners such as ní Cléirigh softened. On 16 April 1940, Anthony D’Arcy died following fifty-two days on hunger strike. Throughout his protest, Anthony had refused medical examination. At a subsequent inquest, ex-IRA Chief of Staff and lawyer Seán MacBride (and son of Maud Gonne MacBride) addressed the jury stating that individuals convicted for political reasons should be awarded political status. He accused the government of inhumanity and intolerance. ${ }^{60}$ The verdict read 'exhaustion from want of nourishment', although the jury recommended that action should be taken in relation to other hunger strikers. ${ }^{61}$ In the face of sharp criticism, de Valera re-reiterated that hunger strikers could not dictate government policy. ${ }^{62}$ Three days after Anthony's death (and four hours after the protest had been called off), Jack McNeela died after a fifty-five day hunger strike. Jack was the nephew of Fianna Fáil TD Michael Kilroy. ${ }^{63}$ At the inquest that followed, Seán MacBride charged Boland with responsibility for the unnecessary deaths of two republican men. ${ }^{64}$

Whereas the death of Terence MacSweeney and others had caused international outrage and elicited considerable sympathy for the cause of full Irish autonomy, Emergency-period hunger strikes took place in an environment that lacked overwhelming support for IRA violence and where partition had been gradually, sometimes reluctantly, accepted. Notably, although D'Arcy's death received media coverage in both Ireland and England, the Daily Mirror speculated that 'Dublin, with the exception of the small IRA following, appears unmoved by the news of D'Arcy's death. ${ }^{65}$ If accurately reported, this situation compared unfavourably with 
earlier incidences of death from hunger strike. In the 1940s, prisoners were not dying in support of the Irish nation, they died because they opposed it. As John Maguire suggests, de Valera was essentially the first politician to successfully undermine the power of the hunger strike as a weapon of political confrontation. ${ }^{66}$

Emergency-period hunger strikes were limited in scope and failed to elicit political change. Faced with a government resolutely opposed to conceding to IRA demands, prisoners and internees realised the futility of starving themselves and, for the most part, refrained from hunger striking following the deaths of Anthony D'Arcy and Jack McNeela. When hunger strikes did take place, the IRA struggled to amass public support or maintain group cohesion while in prison. Public enthusiasm for an internal war against the Irish and Northern Irish states remained limited, a backdrop that did little to boost morale in the prison. When assessed in terms of their political effectiveness, the protests had limited impact. Indeed, de Valera's determinedness not to concede to prisoner demands can be conceived as a Fianna Fáil victory. In many ways, this scenario compares to the outcome of the conscientious objector hunger strikes pursued in the First World War, protests that aroused some degree of humanitarian sympathy towards the plight of prisoners but ultimately failed to attract new recruits. Indeed, the British government, like de Valera's wartime government, successfully re-asserted its authority in maintaining civil order against a backdrop of international crisis.

Nonetheless, imprisoned republicans did help to draw public attention to the adverse prison conditions which they encountered. Upon release, they conveyed evocative details of alleged institutional brutality and violence. Their experiences unintentionally helped to shape a broader discussion of institutional conditions in both Ireland and Northern Ireland. Former IRA Chief-of-Staff, Seán McCaughey, went on hunger strike in April 1946 at Portlaoise Prison. Four years earlier, Seán had been sentenced to death for assaulting Stephen Hayes, ex-Chief of Staff of the IRA and an alleged gardaí informer. Seán's sentence was subsequently commuted to life. Notably, Seán went on hunger strike to protest against the brutal and inhumane institutional conditions in which he resided. After sixteen days of refusing food, he refrained from drinking. Seán died on the twenty-third day of his hunger strike (and eighth day of his hunger and thirst strike). In May 1946, the Republican Prisoners' Release Association passed a resolution expressing 'the horror and detestation of the inhuman treatment of Seán MacCaughey' and demanding 'the immediate ending 
of the torture of his comrades'. Con Lehane claimed that McCaughey had been 'driven to death by inhuman conditions in Portlaoise Prison' and described the prisoner as the thirteenth victim of de Valera's prison system. ${ }^{67}$

A jury returned a verdict of death caused by heart failure brought on by inanition and dehydration caused by a lack of food and fluid intake. Importantly, the inquest provided Seán MacBride with an important opportunity to initiate a discussion of Irish prison conditions. ${ }^{68}$ Macbride brought to the witness stand a sense of emotion and drama that the public could identify with. During the proceedings, he brought to light the fact that Seán McCaughey had not been allowed outside into the fresh air or sunlight during four years of imprisonment. In consequence, Seán had suffered numerous nervous breakdowns. When asked by MacBride, 'If you had a dog, would you treat it in that fashion?', Dr Duane, after a brief pause, reluctantly replied 'no'. MacBride concluded his scathing indictment of Seán's imprisonment by asserting, 'my submission is that the treatment meted out to this man was responsible for his death in this place called a prison, which is a hell' ${ }^{69}$ The jury concurred, stating that 'the conditions existing in the prison were not all that could be desired according to evidence furnished. ${ }^{70}$ Following the inquest, an anonymous letter sent to de Valera on the subject of Seán's death compared Irish prison conditions to the barbarity of Russian institutions. Moreover, allegations of prison brutality provided a platform upon which to campaign for the release of other interned prisoners, most notably the son of Tómas MacCurtain (the murdered Lord Mayor of Cork who had preceded Terence MacSweeney in the position). ${ }^{71}$

McCaughey's death reinvigorated public interest in prisons. Angered by Seán's plight, in May 1946, the Farmers Party and the Labour Party called for an inquiry into conditions at Portlaoise, although this was defeated. Seanad Éireann passed a motion calling for an inquiry. A subsequent report condemned prison conditions, devoting a dedicated section to the plight of political prisoners who appeared to have been treated particularly harshly. The findings of the report formed the basis of Labour Party prison policies from the late 1940s. Between 1946 and 1947, a number of administrative changes were made aimed at improving material conditions in Irish penal institutions. These included an increase in the number of visits, extended privileges, improved diet, more appropriate recreation facilities, and a general trend towards rehabilitation rather than reform. ${ }^{72}$ Indeed, following the McCaughey revelations, serious efforts were made 
to improve conditions in institutions such as Portlaoise which witnessed a dramatic improvement in prison conditions and in areas such as prison diet. ${ }^{73}$ Perhaps more significantly, the death of Seán McCaughey served as a springboard for the various disparate political elements that would eventually coalesce around MacBride and his call for the formation of a new constitutional republican political platform. In 1948, Clann na Poblachta replaced Fianna Fáil in power. ${ }^{74}$

Notably, Seán McCaughey's prison death coincided with a hunger strike initiated in Belfast Prison by David Fleming whose plight aroused similar concerns about Northern Irish prison conditions. In 1944, twenty-eight prisoners, led by former IRA Chief of Staff Hugh McAteer, went on hunger strike in Belfast Jail to protest against poor quality food and unhealthy conditions. Force-feeding was not performed as the prison governor and the Minister of Home Affairs chose to ignore the protest. ${ }^{75}$ Yet David Fleming was force-fed in 1946. He also claimed to have suffered violent manhandling during the procedure. ${ }^{76}$ Notably, David went on hunger strike in response to alleged brutality and victimisation by prison staff, not to secure political status or release. He was subject to brutal beatings. On one occasion, so much of his blood splattered over the cell walls that they needed to be whitewashed..$^{77}$ In 1946, David staged two hunger strikes. The first lasted for eighty-two days; the second for forty-eight. During his first hunger strike, David was force-fed for five days, although the prison doctors were unable to pursue this treatment for longer as David was prone to violently attacking them. ${ }^{78}$ After his last assault on the prison doctor, David found himself placed in a padded cell. Minister of Home Affairs Edmond Warnock brought in a psychiatric specialist to assess David's mental health. The specialist found no reason to diagnose the prisoner as mentally unstable. Warnock invoked the diagnostically vague term 'religious mania'. However, Fleming's hunger strike was too purposeful for a convincing claim of insanity to be formed..$^{79}$ Given a tendency of prison medical staff to proclaim hunger strikers as mentally unsound, Warnock's efforts can be interpreted as an attempt to permanently remove a troublesome politicised prisoner from the institution. Towards the end of his second protest, David was released and transported in a weak, emaciated condition to Pembroke Nursing Home, Dublin, a journey of over hundred miles. ${ }^{80}$ Despite having been ordered not to return to Belfast, David was apprehended in September 1947 at Nutts Corner Airport, Belfast, after arriving from Dublin in an Aer Lingus plane. He then went on a further hunger strike. ${ }^{81}$ 
David's experiences can be situated in a broader context of discussion about Northern Irish prison conditions. Two years earlier, questions had been raised in the House of Stormont about whether prisoners were hunger striking in Belfast Prison to protest against harsh, humiliating institutional conditions. ${ }^{82}$ Labour Party MP, Jack Beattie, had claimed that prisoners were being regularly subjected to unnecessary cell searches and strippings, as well as indecent searching by the warders who accompanied their intrusive cavity inspections with verbal abuse and insults. Beattie also pointed out that politically motivated prisoners were being placed in cells where they were forced to associate with individuals committed for sexual crimes, to listen 'to their filthy and degrading talk'. In addition, Beattie claimed that food rations fell far below the authorised allowance. It was also badly cooked and served on unwashed plates. Milk was watered-down and cocoa served in tins containing remnants of turnips and vegetables. Beattie insisted that 'Northern Ireland is the only place in the world where you find cruelty existing to the extent that I outlined.' He concluded his powerful indictment by announcing 'we are more akin to the Nazis in Germany than we are to the democratic world outside it', adding his intention to appeal to the American Red Cross and the Council of Civil Liberties. ${ }^{83}$

Although Stormont MPs paid scant attention to the political dimensions of David Fleming's hunger strike, a number of them expressed concern over his motivations for hunger striking; rooted as they were in broader questions about prison conditions. Fleming's protest raised important questions about the extent to which imprisonment-with its monotony, loss of individuality, and endless punishment-truly reformed or aimlessly punished. In the House of Stormont, Mr Healy suggested that 'the present [prison] buildings ought to be blasted to the ground' and called for a public inquiry into the state of Northern Irish prisons. Healey emotively concluded by pleading:

I ask you, if you have any humane instincts left in you, not to look on this from a prejudiced point of view. Think of this boy Fleming being brought into his cell by four or five warders and there beaten. His skull was crashed in and he was left lying for hours with blood flowing from his head. Is it any wonder that to-day he is on hunger strike? Is it any wonder that previous to that he acted in an irrational manner? Surely if we are not blinded by prejudice and carried away with political sentiment, the time has come when matters should be looked into and an impartial inquiry held. ${ }^{84}$ 
It seems evident that Irish republicans were treated with undue harshness and violence while imprisoned during the Emergency and Second World War. War justified their detainment and encouraged hostility between staff and prisoners. The context of war also allowed politicians, including de Valera, to support actions that would normally be deemed harsh, including letting a number of hunger strikers die. His strategy was successful in terms of quelling hunger strikes but raised broader humanitarian concerns. Yet, as is often the case when wartime prisoners are treated harshly, prisoners amassed considerable public attention when news of the violence inflicted upon them reached beyond the prison walls, in this instance, raising calls for prison reform.

\section{Conclusion}

During wartime, politicised prisoners often pursue activities that seem to threaten the integrity of the state. They find themselves exposed to imprisonment and a relative lack of public sympathy in their plight. A need to protect national security interests justifies particularly brutal methods of force-feeding or, in some instances, a willingness to let starvation run its natural course. Censorship and appeals made to the over-riding concern of securing military victory ensure that the fate of politicised hunger strikers remains mostly hidden from public view. Nonetheless, politicised prisoners are often adept at drawing attention to the harsh conditions in which they reside, either through their supportive political network or through their own subsequent writings. This produces a mixed emotional response. While public support for conscientious objection or IRA activity was minimal in the contexts discussed in this chapter, the idea that suffering was being inflicted upon individuals forced to live in inhumane conditions clashed with public sensibilities on how humans should be treated. The prisoners had suffered enough by being isolated from society. Was it really necessary to beat, punish, and brutally force-feed them? In many ways, wartime hunger strikers are relatively powerless in comparison to their peacetime counter-parts. They feel the weight of sovereign power working against them due to the additional powers conferred on wartime governments. But paradoxically, it is these groups of hunger strikers that historically made the most inroads into campaigning for 
institutional reform. The harsh treatment meted out to them remained vivid in their memories, encouraging participation in prisoner welfare movements. Perhaps the greatest achievements of the hunger strikers analysed in this chapter was their ability to raise a broader set of questions about the milieu of prison life, even if their disparate political aspirations ultimately failed.

\section{Notes}

1. See, among others, Jon Moran, 'State Power in the War on Terror: A Comparative Analysis of the UK and USA', Crime, Law and Social Change, 44:4-5 (December 2005), pp. 335-59.

2. Weiner, Reconstructing the Criminal, p. 327.

3. E.g. Murphy, Political Imprisonment and the Irish; Thomas Hennessey, Hunger Strike.

4. Political history itself has tended to pay scant attention to the history of emotions. See Martin Francis, 'Tears, Tantrums and Bared Teeth: The Emotional Economy of Three Conservative Prime Ministers', Journal of British Studies, 41:3 (July 2002), pp. 354-87.

5. E.g. Moazzam Begg, Enemy Combatant: The Terrifying True Story of a Briton in Guantánamo (London: Pocket Books, 2007); Mahvish Khan, My Guantanamo Diary: The Detainees and the Stories they Told Me (New York: Public Affair Books, 2008); Mohamedou Ould Slahi, Guantánamo Diary (New York: Little, Brown and Company, 2015).

6. E.g. Cole, Enemy Aliens; Smith, Bad Men.

7. John Rae, Conscience and Politics: The British Government and the Conscientious Objector to Military Service, 1916-1919 (Oxford: Oxford University Press, 1970), pp. 201-4.

8. David Boulton, Objection Overruled (London: MacGibbon and Kee, 1967), p. 219.

9. Lois S. Bibbings, Telling Tales about Men: Conceptions of Conscientious Objectors to Military Service during the First World War (Manchester: Manchester University Press, 2009), p. 7, p. 115 and p. 141.

10. 'C. O.'s Prison Waistcoat: Objector's Action against Army Officer', Observer (29 July 1917), p. 10.

11. Kew, PCOM2/465, 'Register of Criminal Prisoners on Hunger Strike (other than Suffragettes)', 1913-40.

12. 'Conscientious Objectors', House of Commons Debates (20 June 1917), vol. 94 cols 1766-77. 
13. Emily Lutyens, 'The Case against Persecution: The Case of Emmanuel Ribeiro', Manchester Guardian (3 July 1917), p. 3.

14. Alfred Salter, 'The Case of Ribeiro', Manchester Guardian (18 February $1918)$, p. 8.

15. 'Emmanuel Ribeiro Released', Manchester Guardian (11 June 1918), p. 3.

16. 'C. O.'s Action against an Officer', Manchester Guardian (27 July 1917), p. 7.

17. 'Conscientious Objectors', House of Commons Debates (4 June 1918), vol. 106 cols 1385-6.

18. Kew, HO45/10418/183577/351, 'Leigh Vs Gladstone: Medical Evidence', 7 December 1909; Leigh v Gladstone.

19. Kew, HO144/1490/356124, 'Transcript of Shorthand Notes of the Proceedings of an Inquiry held by Sir W. Watson Cheyne and Dr Maurice Craig at H. M. Prison, Hull', 6 April 1918.

20. 'Transcript of Shorthand Notes'.

21. 'Prisoner's Death, Hull', House of Commons Debates (15 April 1918), vol. 105 cols 54-5W.

22. Ibid.

23. Stephen Hobhouse and A. Fenner Brockway, English Prisons Today (London: Longmans, Green, 1922).

24. Five Years Penal Servitude (London: Routledge, 1893); Weiner, Reconstructing the Criminal, p. 323.

25. Arthur S. Peake, Prisoners of Hope: The Problem of the Conscientious Objector (London: G. Allen and Unwin, 1918), pp. 117-9.

26. 'Vote on Account', House of Commons Debates (10 March 1919), vol. 113 cols 945-1052.

27. Richard Michael Fox, Drifting Men (London: Leonard and Virginia Woolf, 1930), pp. 117-18.

28. Fox, Drifting Men, p. 119.

29. 'More Demonstrators go to Prison: Hunger Strike Still On', Times (10 January 1959), p. 10.

30. 'Secrets Case Woman on Hunger Strike', Times (3 March 1962), p. 5.

31. 'Forcible Feeding of Airman Considered', Times (17 September 1962), p. 6.

32. 'Hunger Strike Girl Pat Gets Solitary', Daily Express (14 October 1961), p. 13.

33. 'Miss Pat Arrowsmith', House of Commons Debates (24 October 1961), vol. 646 cols $728-34$.

34. Judith Hart, 'Civil Defence Tasks in Prison', Guardian (21 October 1961), p. 6.

35. Emrys Hughes, 'The Case of Miss Arrowsmith', Guardian (19 October 1961), p. 10. 
36. Owen Staley, 'Miss Arrowsmith's Treatment', Guardian (17 October 1961), p. 10.

37. C. H. Law, 'Miss Arrowsmith's Treatment', Guardian (17 October 1961), p. 10.

38. 'Prison Breakthrough', Guardian (25 January 1971), p. 9.

39. For recent analysis, see Ciara Meehan, The Cosgrave Party: A History of Cumann na nGaedheal, 1923-33 (Dublin: Royal Irish Academy, 2010).

40. Stephen Kelly, Fianna Fáil, Partition and Northern Ireland, 19261971 (Dublin: Irish Academic Press, 2013), pp. 46-52. For a broader overview of IRA activity in this period, see Brian Hanley, The IRA, 1926-1936 (Dublin: Four Courts Press, 2002).

41. O'Halpin, Defending Ireland, pp. 246-8.

42. NAI, TAOIS/S7788B, 'Death Sentences: Procedure', undated.

43. O'Halpin, Defending Ireland, p. 252.

44. John Maguire, IRA Internments and the Irish Government: Subversives and the State, 1939-1962 (Dublin: Irish Academic Press, $2008)$, p. 3.

45. NAI, TAOIS/S11515, 'Memorandum', 13 November 1939; 'Prisoners on Hunger Strike: Ministerial Statement', Dáil Éireann Debate (9 November 1939), vol. 77, no. 8.

46. 'Hunger and Thirst Strike: Dublin Solicitor in Arbour Hill', Irish Times (20 October 1939), p. 8.

47. 'Private Notice Question: Prisoner on Hunger Strike', Dáil Éireann Debate (19 October 1939), vol. 77 no. 6.

48. NAI, PRES/1/P1421A, 'Letter from Madam Gonne MacBride to Douglas Hyde', 8 November 1939.

49. Caoimhe Nic Dháibhéid, Seán MacBride: A Republican Life, 1904-1946 (Liverpool: Liverpool University Press, 2011), p. 137.

50. NAI, TAOIS/S11515, 'Memorandum', 18 November 1939.

51. Clair Wills, That Neutral Island: A History of Ireland during the Second World War (London: Faber, 2008), pp. 93-4.

52. 'Offences Against the State (Amendment) Bill 1940: Second Stage', Seanad Éireann Debate (5 January 1940), vol. 24, no. 6.

53. O'Halpin, Defending Ireland, p. 248.

54. NAI, TAOIS/S11515, 'Demands of the Prisoners Now on Hunger Strike in Mountjoy and Arbour Hill', undated; Maguire, IR A Internments, pp. 30-3.

55. NAI, TAOIS/S11515, 'Letter from Laurence Grogan to Éamon de Valera', 19 March 1940. 
56. www.soviet.ie/index.php?/topic/1028-hunger-strikers-of-1940remembered. Accessed 17 June 2014, 15.25pm.

57. NAI, TAOIS/S11515, 'Letter from Josephine Mary Plunkett to Cardinal Joseph McRory', 14 March 1940.

58. NAI, TAOIS/S11515, 'Letter from Madam Gonne MacBride to Cardinal Joseph McRory', 20 March 1940.

59. 'The Hunger Strike', Irish Times (25 March 1940), p. 5.

60. 'Prisoner who Died on Hunger Strike: Jury's Findings at Dublin Inquest', Irish Times (18 April 1940), p. 2.

61. 'Inquest on Hunger Striker', Manchester Guardian (18 April 1940), p. 9.

62. NAI, TAOIS/S11515, 'Letter from Éamon de Valera to Caitlin Bean ní Cléirigh', 20 April 1940.

63. 'Death of Second Hunger Striker', Irish Times (20 April 1940); Dháibéid, Seán MacBride, p. 144.

64. NAI, TAOIS/S11515, 'Evidence Taken at the Inquest of John McNeela', 22 April 1940; Dháibéid, Seán MacBride, p. 145.

65. 'Fifty-Two Day Fast: Dies', Daily Mirror (17 April 1940), p. 7.

66. Maguire, IRA Internments, p. 33.

67. NAI, TAOIS/S13854, 'Hunger Strikes', 1946.

68. Nic Dháibhéid, Seán MacBride, pp. 96-9.

69. 'Hunger Strikes', 1946.

70. 'Hunger Striker's Prison Death: Protest at Inquest', Manchester Guardian (13 May 1946), p. 5.

71. NAI, TAOIS/S13854, 'Letter from Sorely Disappointed to Éamon De Valera', 21 May 1946.

72. Mary Rogan, Prison Policy in Ireland: Politics, Penal Welfarism and Political Imprisonment (London: Routledge, 2011), pp. 64-72.

73. 'Committee on Finance-Vote 32-Office of the Minister for Justice (Resumed)', Dáil Éireann Debate (23 June 1948), vol. 111, no. 11.

74. Maguire, IRA Internments, p. 59.

75. 'I.R.A. Chief does Fifteen Days of Death Fast', Daily Express (8 March 1944), p. 1.

76. 'Hunger Strikes', 1946.

77. 'Prison Administration', Stormont Papers, 30 (21 May 1946), p. 730.

78. PRONI, CAB9G/19/4A, 'The Case of David Fleming: Statement by the Ministry of Home Affairs-Hunger Striker not to be Released', I May 1946.

79. 'Belfast Prison: David Fleming', Stormont Papers, 30 (21 November 1946), p. 2789.

80. 'Fleming now in Dublin Nursing Home', Irish Independent (30 November 1946), p. 2. 
81. Irish Press (22 September 1947), p. 2.

82. 'Belfast Prison Hunger Strike', Stormont Papers, 27 (7 March 1944), pp. 432-3.

83. Ibid., pp. 490-502.

84. 'Prison Administration', Stormont Papers, 30 (21 May 1946), pp. $724-56$.

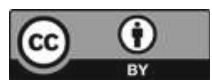

This chapter is distributed under the terms of the Creative Commons Attribution 4.0 International License (http://creativecommons.org/ licenses/by/4.0/), which permits use, duplication, adaptation, distribution and reproduction in any medium or format, as long as you give appropriate credit to the original author(s) and the source, provide a link to the Creative Commons license and indicate if changes were made.

The images or other third party material in this chapter are included in the work's Creative Commons license, unless indicated otherwise in the credit line; if such material is not included in the work's Creative Commons license and the respective action is not permitted by statutory regulation, users will need to obtain permission from the license holder to duplicate, adapt or reproduce the material. 


\section{'I Would Have Gone on with the Hunger Strike, but Force-Feeding I Could Not Take': The Coercion of Hunger Striking Convict Prisoners, 1913-72}

Do prison doctors force-feed to save lives or to punish? The answer to this is unclear. In reality, it seems likely that doctors hold differing views on the ethics of force-feeding. Their opinions might also depend upon the particular context in which they perform force-feeding. This chapter argues that, regardless of intention, force-feeding has proven itself in the past to be a remarkably effective weapon for stamping out hunger strikes. In December 2005, Guantánamo received a delivery of mobile restraint chairs, similar to those used in maximum-security prisons for violent mentally ill patients. Previously, Guantánamo detainees had been nasally fed. However, this new method of feeding involved strapping prisoners to a chair and inserting a forty-three inch tube through the body twice a day. It was infinitely more uncomfortable than nasal feeding. The number of detainees on hunger strike dropped swiftly from twenty-four to six. ${ }^{1}$ Even if prison doctors do genuinely believe it is their ethical duty to save lives, stomach tube feeding clearly serves a purpose in quelling prison protests, adding to the sense of physical and mental discipline felt by prisoners.

Exploring the experiences of force-fed twentieth-century convict prisoners can shed light on this matter. In 1913, the Prison Commissioners of England and Wales began to maintain a register of hunger strikes in English prisons. The Commissioners meticulously recorded prisoner motivations for hunger striking, the methods used by prison doctors to deal with food refusal, and the prisons in which protests took place. Initially, the Commissioners' register was intended as an inventory of non-political 
hunger strikes. Accordingly, they refrained from recording suffragette hunger strikes, although Irish republicans imprisoned in England occasionally seeped into the register. This imperative to record non-political protests alone presumably stemmed from anxiety about the prospect of convict prisoners attempting to use the Cat and Mouse Act-implemented in the same year as the register began-to secure premature release after witnessing the efficacy of militant suffragettes in gaining temporary freedom by refusing food. ${ }^{2}$ In 1913, one convict prisoner, Albert Davis, died in Bedford Gaol during a hunger strike inspired by the suffragettes. Shortly after, the Prison Commissioners amended their rules on reporting incidences of food refusal. ${ }^{3}$

The Prison Commissioners stopped recording entries in 1940 as space ran out in the pages of their register. Yet between 1913 and 1940, they made note of 834 prisoners who went on hunger strike. Collectively, these prisoners staged 1,188 hunger strikes. Only forty were IRA members, leaving a remainder of 794 convict prisoners with no obvious political affiliation. In twentieth-century England, hunger striking maintained a notable presence as an expression of remonstration that disrupted the normal disciplinary workings of penal institutions and challenged established power relations between staff and prisoners. Hunger strikes peaked between 1918 and 1921, and again between 1939 and 1940, due to the presence of Irish republican prisoners in English prisons. Nonetheless, in the intermittent period, the Commissioners recorded an average of 27.7 prison hunger strikes per year. ${ }^{4}$ Between 1940 and the mid-1970s, newspapers continued to report incidences of prison hunger striking, indicating that prisoners continued to refuse food throughout much of the century. This points to an important legacy left by the suffragettes and Irish republicans: their demonstration of the potency of food refusal to rebel against prison life.

James Vernon has emphasised the powerful role of hunger striking in defying the state and formulating political critique. ${ }^{5}$ Nonetheless, prisoners also refused food to address concerns relating to deplorable institutional conditions and a loss of rights. The erosion of personal rights that was intrinsic to the rapid rise of the disciplinary prison in the nineteenth century — starkly characterised by silence, solitude, and discipline-created a milieu in which prison staff tended to disregard prisoner complaints and deny inmates opportunities to protest against aspects of their imprisonment. As this chapter demonstrates, convict hunger strikes were often predicated upon re-asserting individual rights in an institutional setting 
that hinged upon conformity, reform, and strict behavioural control. Many prisoners who abstained from food did so in response to issues such as poor quality diet or harsh punitive treatment. They sensed an inherent inequity in place and sought to redress that imbalance by simply refusing to eat. Yet the modern prison, by its very nature, discouraged, and sought to suppress, the notion that prisoners could input into, or rally against, the conditions of their incarceration. ${ }^{6}$ Food refusal threatened institutional order by granting prisoners the autonomy to dictate how they interacted with the prison environment.

Medical staff preferred to force-feed rather than address prisoner concerns. In the public imagination, force-feeding is most commonly associated with the suffragettes and, in Ireland, with Thomas Ashe. However, in England, the practice remained in force as a coercive disciplinary technique throughout much of the twentieth century. If anything, the mass hunger strikes staged in the 1910s demonstrated the coercive value of stomach and nasal tubes in subduing recalcitrant prisoners. In their register, the Commissioners carefully noted whether hunger strikers had been forcefed; if so, how many times; and the instrument that had been used to feed. Between 1913 and 1940, the Commissioners recorded a total of 7734 force-feedings. ${ }^{7}$ In the post-war period, newspapers published accounts of hunger striking and force-feeding with rising frequency. Thomas Ashe's 1917 prison death following a fatal bout of force-feeding should not be understood as a controversial watershed that resulted in the discontinuance of prison feeding practices, as is often presumed to be the case. ${ }^{8}$ On the contrary, as this chapter demonstrates, the history of force-feeding can be re-assessed to account for the sustained use of feeding technologies on convict prisoners.

In turn, this raises important questions about the function of twentiethcentury prison medicine in regulating personal behaviour, maintaining prison order, and imposing discipline on the body. Twentieth-century English prisons remained modelled upon Victorian principles of deterrence and character reform. ${ }^{9}$ In the previous century, reformers had dramatically re-designed the prison, replacing a somewhat chaotic nationwide penal system with a rationalised, uniform prison network. Although predicated on humanitarian grounds, the reformed prison was notorious for the strict imposition of disciplinary regimes, including severe dietary restrictions, eighteen-month periods of solitary confinement and imposed silence. ${ }^{10}$ Michel Foucault argued that the modern period witnessed a shift from inflicting punishment on the body (by whipping and chaining) to 
regulating the mind (through psychological mechanisms such as the silent system). ${ }^{11}$ The criminal body-once subject to hanging and dismemberment-became exposed to less overtly physical methods of punishment. ${ }^{12}$ When prison officials decided to touch the body, it was to reach something inside - perhaps the 'soul', as Foucault claimed-but certainly the mind. ${ }^{13}$ Indeed, the ongoing use of physical punishments such as force-feeding confirms the more nuanced suggestion that physical and psychological punishment co-existed in the modern prison. ${ }^{14}$ Force-feeding seems to have been resorted to with the primary aim of 'rectifying' the behaviour of rebellious prisoners.

\section{Prison Hunger Strikes and Force-Feeding, C. $1913-40$}

[Hunger strikes are] very rarely carried through by criminals as a protest against physical misery imposed by prison conditions or prison discipline; for, however great the hardships of their lot may be, these are only intensified by the pains of starvation and the prospect of a lingering death. The hunger strike can be carried out only by men and women of iron will and endurance who feel themselves to be fortified by the strength of an inward conviction and are driven to use this weapon (whose point is directed upon their own heart) by the sense that for others, as well as for themselves, they have to protest against intolerable injustice and against moral and spiritual as well as physical cruelty. ${ }^{15}$

In 1929, WSPU treasurer Emmeline Pethick-Lawrence published this statement in The Guardian while reflecting on the suffragette hunger strike campaign. Emmeline perceptively recognised that hunger strikes are most effective when staged by an organised, mutually supportive unit of prisoners who share a common moral cause. She also pointed to a perceived sense of injustice-strengthened by perceptions of institutional cruelty - that, in her opinion, underpinned most decisions to abstain from food. Is Pethick-Lawrence's statement supported by later twentieth-century evidence? Why did twentieth-century convict prisoners hunger strike? What motivated them? And how successful were their protests?

Between 1913 and 1940, prison medical officers responded to 571 (52.5\%) hunger strikes with force-feeding. It can be reasonably assumed that medical staff threatened a significant number of other hunger strik- 


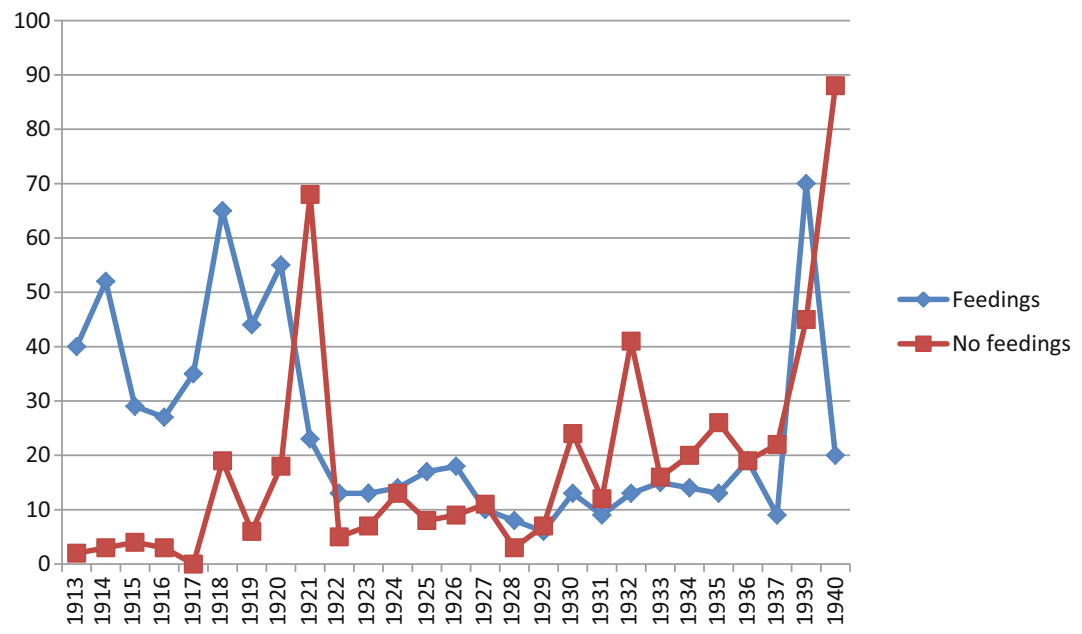

Fig. 6.1 Number of recorded hunger strike incidences responded to, and not responded to, with force-feeding in English Prisons, 1913-40 (Source: Kew, PCOM 2/465, 'Register of Criminal Prisoners on Hunger Strike (other than Suffragettes)', 1913-40)

ers with feeding technologies, successfully undermining their protests. It seems probable that more prisoners would have been fed had prison doctors deemed their health sufficient to withstand the procedure. Figure 6.1 details the number of force-feedings performed in prisons in this period and irrefutably discredits the presumption that prison staff stopped forcefeeding in 1917.

Importantly, force-feeding continued to be used in English prisons despite an awareness that the procedure could kill. When William Edward Burns died in Hull in 1918 after being fed against his will, the Home Office feared that public opinion would be inflamed and drawn towards the cause of conscientious objection in much the same way that Ashe's death had allowed Irish republicans to amass support for national independence. Private Home Office communication stated that:

This particular prisoner was certified to be in good general health and so presumably the operation of artificial feeding would be without physical detriment or danger, but the case has proved that even in the case of healthy subjects there is a contingent danger to life, though we cannot speak with certainty on this point until after the Coroner's inquest. If then, there is a 
contingent danger to life even in the case of those certified to be physically fit for the operation, it follows that the whole question of forcible-feeding in prisons must be raised and determined in light of this case, unless release from prison is to be the regular sequence of refusal to take food. ${ }^{16}$

Immediately after Burns' death, the Commissioners distributed a circular to all prisons advising that 'artificial feeding' should no longer be performed on conscientious objectors who should instead be temporarily released under the Cat and Mouse Act. ${ }^{17}$

Despite the well-publicised deaths of Thomas Ashe and William Edward Burns, force-feeding remained remarkably intact as a standard component of the prison doctor's arsenal for disciplining convict prisoners. Convict prisoners almost always initiated hunger strikes alone. Unlike the mobilised groups of suffragette and Irish republican prisoners who purposefully went on hunger strike en masse, convicts tended not to inspire other prisoners to sympathetically hunger strike. As William Murphy notes in relation to Ireland, hunger strikers without a firm cause or the support of their fellow prisoners rarely sustained their protests. ${ }^{18}$ Murphy's contention is borne out in twentieth-century English prison contexts.

To justify the ongoing use of force-feeding, the Commissioners routinely referred to the historical case of Leigh v Gladstone of 1909. As discussed in Chap. 2, this established legal precedence for the questionable argument that prison doctors were required to force-feed in line with their medical ethical duty to preserve health and save lives. ${ }^{19}$ This medicalisation of the hunger strike-now divorced from its political and institutional dimensions-ensured that food refusal continued to be designated as a medical concern long after the militant suffragette and Irish republican campaigns ended. From 1913, prison medical staff were obliged to report hunger strikes to the Commissioners (who, in turn, made a note in their register) and convey details of force-feeding. The Commissioners left the matter of whether hunger strikers were to be fed to the discretion of prison medical staff. ${ }^{20}$ Reinforcing a sense that hunger striking was a problem that demanded therapeutic intervention (as opposed to a valid form of protest), in January 1918, the Commissioners distributed a circular that clearly outlined their stance on the desirability of treating hunger strikers as hospital patients, either in the prison hospital or in their prison cells. ${ }^{21}$

Throughout the early twentieth century, the institutional role and influence of prison medical staff considerably expanded, in part because their expertise in criminology became highly valued both inside and outside of 
the institution. ${ }^{22}$ While it could be argued that prison doctors felt caught in a dual loyalty to their profession and their institutional workplace, Joe Sim maintains that many of them willingly, if not enthusiastically, contributed to the disciplinary ethos of prisons by enforcing prison regimen and inflicting punishment. Prison doctors developed an armoury of techniques designed to deal with troublesome prisoners and played an active role in maintaining institutional order. ${ }^{23}$

If anything, the frequent resort of English prison doctors to forcefeeding seems relatively unremarkable given that they regularly prescribed large quantities of psychotropic drugs to subdue unruly prisoners, removed parts of their prisoners' brains when performing surgical lobotomies, and used electro-convulsive therapy to modify seemingly disruptive behaviour patterns. ${ }^{24}$ Some post-war physicians hoped that increasingly sophisticated forms of bodily intervention would one day be developed to enhance the 'treatment' of crime in prisons. Hormones and pharmaceutical substances could be developed to reduce the numbers of sexual offenders; new brain surgery methods might be developed to modify anti-social behaviour; and medications might be produced to sedate criminals with violent tendencies. ${ }^{25}$ Others suggested that prisons could be transformed into therapeutic communities, a concept borrowed from post-war psychiatric thought that emphasised the value of techniques such as group counselling. ${ }^{26}$ What seems clear is that prison medical staff tended to view the imprisoned population as a consortium of individuals who refused to adapt themselves to a socially acceptable mode of living. ${ }^{27}$ This created a climate of thought that encouraged crime to be viewed as a personal disorder requiring rectification rather than a negative effect of environmental or social problems. Prison doctors saw their role as being to 'treat' the moral and psychological problem of criminality through processes of socialisation and behavioural normalisation. In this context, food refusal came to be frowned upon as a potent expression of behavioural disorder, a perspective that undermined any sense that a prisoner's grievances might, in some cases, be valid.

In the twentieth-century English prison, the boundaries between therapy and coercion remained remarkably fluid, reinforcing a sense felt among prisoners that prison medicine was central to the disciplining of the institutionalised body. It did not simply serve benevolent, healthimproving purposes. Indeed, the Prison Medical Service-autonomous from the broader national health system-came under increasing scrutiny precisely because of its penalising tendencies throughout the twentieth 
century, as evidenced by the publication of the Prison System Enquiry Committee's damning English Prisons Today in 1922 (led by Stephen Hobhouse and A. Fenner Brockway) and Roger Page's highly critical Prison Medical Service in $1943 .{ }^{28}$ Nonetheless, despite mounting public criticism, the role of prison medical staff continued to expand, particularly in the post-war period. ${ }^{29}$ The few individuals aware of the ongoing use of force-feeding commented on the coercive or careless intentions of those performing the procedure. In 1922, Hobhouse and Brockway reported that prison medical staff took the matter of force-feeding 'too lightly' and insisted that the procedure was performed with insufficient care and in spite of a broader consensus among physicians outside of the prison on its potential dangers. ${ }^{30}$ More assertively, in 1922, Mary Gordon published a critical account of her experiences as the first Lady Inspector of English Prisons, a post that she held between 1908 and 1921. In Penal Discipline, she asserted that:

An offender is sent to prison by the judge or magistrate so that he may undergo penal discipline which, with loss of liberty, is his punishment. Once in prison, if he attempts to do his own will, to offend against the prescribed order, to disobey, resist, or assault his gaolers, he can be punished again by the Governor or the Justices. He can be coerced or punished in various ways, by forfeiture of remission, loss of privilege, by dietary deprivations, by separate or close confinement. His body may be restrained, day and night, in irons, or tied up and flogged. He can be forcibly-fed (a treatment called medical, but in reality disciplinary) in order to prevent his determining his imprisonment. In short, we are not afraid to hurt, or injure, or cause him to run risks, in order to master him. ${ }^{31}$

Gordon equated force-feeding with brutality and identified the procedure as part of a broader web of coercion that was ultimately failing to rehabilitate and reform. She concluded that 'during my service I found nothing in the prison system to interest me, except as a gigantic irrelevance-a social curiosity. If the system had a good effect on any prisoner, I failed to mark it. I have no shadow of doubt of its power to demoralise, or of its cruelty. It appears to me not to belong to this time or civilisation at all. ${ }^{32}$

Prisoners undoubtedly struggled to challenge the imbalanced power systems that structured the twentieth-century prison. Only one recorded incidence exists of a force-fed prisoner taking legal action against prison medical staff. In March 1944, Frederick Bowman prosecuted Drs Grierson and Saville for having used force-feeding 'as a brutal form of unlawful 
punishment', maliciously exceeding their ethical duties, and committing professional misconduct by using an emergency medical procedure to torture and intimidate. To support these strong assertions, Frederick insisted that both doctors had uttered violent threats while feeding him, adding to an underlying sense of torment. Frederick had been detained under Regulation 18B of the Defences Regulation Acts of 1939. This Regulation stipulated that detainees were to be confined for custodial, not punitive, purposes and that their confinement should not be oppressive. Despite this, Grierson force-fed Frederick from the fifth day of his hunger strike, a decision which he subsequently justified with recourse to the argument that prison doctors had an ethical obligation to save lives.

As in the case of Leigh $v$ Gladstone, Bowman $v$ Grierson coalesced around the contested issue of whether force-feeding was therapeutic or coercive. It is impossible to decipher whether Frederick truly believed in the therapeutic benefits of force-feeding or if he chose to resuscitate a familiar medical argument to conceal his hostile behaviour. Nonetheless, the verdict supported the medical perspective and even concluded that the doctors had acted with great kindness towards their patient, not with vindictiveness. Grierson insisted that 'I had no thought of punishment or torture or intimidation. I only looked at it from the medical angle.' Both Grierson and Saville were cleared of assault. ${ }^{33}$ This outcome, which mirrored Mary Leigh's unsuccessful effort to prosecute the Home Secretary and her prison medical staff, reveals much about the power systems in place in the English penal network that worked against the concerns of aggrieved prisoners.

Nonetheless, evidence collated from the Commissioner's register adds weight to Bowman's claim that force-feeding was used principally to coerce and intimidate. Figure 6.2 outlines the number of force-feedings (in relation to individual hunger strikes) performed in English prisons between 1913 and 1940. The procedure clearly brought an overwhelming majority of hunger strikes to an abrupt end. $44 \%$ of hunger strikes (responded to with the stomach or nasal tube) were abandoned after one feeding. Only $28 \%$ lasted beyond a second feeding. As mentioned in the introduction, when Judith Todd, daughter of Rhodesia's former Prime Minister Garfield Todd was force-fed in 1972 (causing a public scandal), she announced, 'I couldn't take it. I failed. I would have gone on with the hunger strike, but force-feeding I could not take'. ${ }^{34}$ Todd's statement perhaps exemplifies the common experience of force-fed prisoners. Working on the presumption that hunger strikers were fed 3 times daily, $70 \%$ of force-fed hunger 


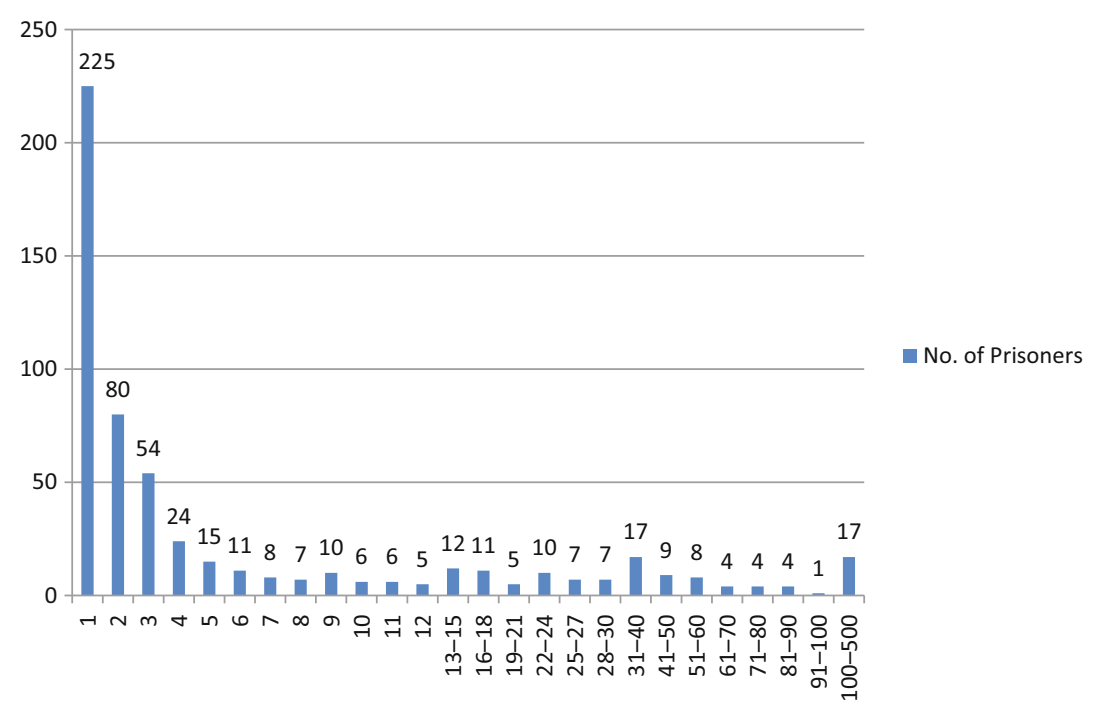

Fig. 6.2 Number of times prisoners were force-fed on individual hunger strikes in English prisons, 1913-40 (Source: Kew, PCOM 2/465, 'Register of Criminal Prisoners on Hunger Strike (other than Suffragettes)', 1913-40)

strikers abandoned their protest within a day. Only $30 \%$ persevered into a second day. $21 \%$ endured beyond two days. Evidently, force-feeding rapidly extinguished episodes of food refusal, quickly restored institutional order, and re-established the normal relationship between staff and prisoners. This suggests that force-feeding had disciplinary value and supports claims made by suffragettes and Irish republicans on the coercive nature of the procedure. Foucault maintained that an essence of torture remained in the modern prison system and it is conceivable that force-feeding was one technology of the body used to implement this. ${ }^{35}$

Moreover, and importantly, the tumultuous events of the Irish War of Independence had made clear that prisoners could abstain from food for around fifteen days without suffering permanent physical harm. However prison doctors tended to force-feed during the early stages of a hunger strike under the auspices of avoiding a looming death, despite a general awareness that human starvation tended not to occur so rapidly. Irish republicans had irrefutably demonstrated that death was unlikely to occur towards the start of a prison fast. The controversial death of Terence MacSwiney in 1920 had confirmed this point. Given the high 
public profile of this prison fatality, the Commissioners and prison staff would presumably have known that force-feeding early on was unnecessary. When viewed from this perspective, it seems plausible that prison medical staff understood that the lives of fasting prisoners were not in immediate danger but recognised that a short feeding period-often one feeding - swiftly ended most hunger strikes.

An underlying sense of coercion was further reinforced by the prison doctor's preference for using intrusive feeding technologies. Figure 6.3 indicates that the stomach or oesophageal tube was the preferred instrument of feeding. Feedings with nasal tubes, stomach pumps, and spoons occurred less frequently. Notably, in 1963, the British Medical Journal suggested that tube feeding was in fact viewed unfavourably in hospital practice due to an absence of standardisation and lack of attention paid to issues such as calorific intake. The journal commented that doctors used gastric tubes so infrequently in hospital practice that subclinical malnutrition was a common problem among patients undergoing prolonged convalescence. ${ }^{36}$ Nonetheless, feeding technologies retained an active purpose in both prison and asylum practice. In the interwar period, the feeding cups occasionally described in suffragette propaganda fell out of fashion,

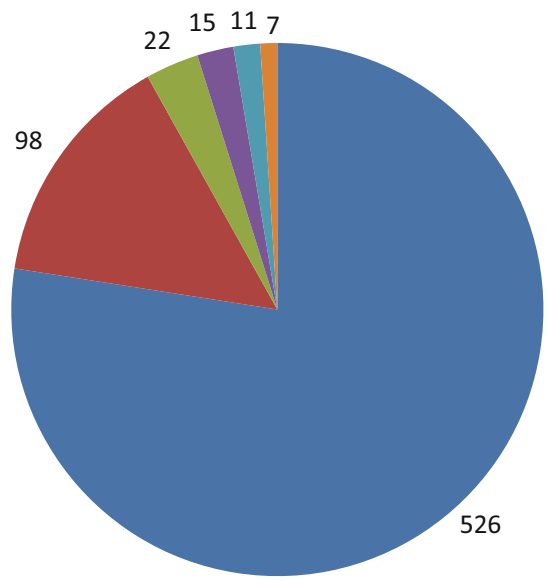

Stomach or Oesophagal Tube

Nasal tube

Spoon-fed

- Nasal and

Stomach/Oesophagal Tube

- Feeding Cup

- Stomach Pump

Fig. 6.3 Instruments used for force-feeding in English prisons, 1913-40 (Source: Kew, PCOM 2/465, 'Register of Criminal Prisoners on Hunger Strike (other than Suffragettes)', 1913-40) 
reflecting changing technological considerations in asylum practice. In his textbook Mind and its Disorders, published in 1926, psychiatrist William Henry Butter Stoddart asserted that the feeding cup was 'a pernicious utensil and a fertile source of pulmonary access and gangrene'. ${ }^{37}$ Two years earlier, Robert Henry Cole had commented in his Mental Diseases that asylum doctors rarely used stomach pumps to feed, instead preferring a soft rubber oesophageal tube. The oesophageal tube, Cole explained, was quicker and easier to use, an attraction for time-consumed, and perhaps impatient, prison doctors. Cole also noted that medical staff could introduce large quantities of semi-solid food into the body with oesophageal and stomach tubes, contrasting with the more cumbersome nasal tube that depended upon inserting liquids, irritated the patient's nasal mucous membrane, and were prone to becoming blocked. ${ }^{38}$ Nonetheless, gastric tubes were the most invasive of technological resources available, and therefore most feared by prisoners. Certainly, suffragette and Irish republican propaganda had focused on the horrors of the stomach tube more intently than the less intrusive, but labour-intensive, nasal tube. The physical invasiveness of gastric tube technologies no doubt reinforced the sense of intimidation felt by fasting prisoners.

Notably, the use of force-feeding was geographically evenly spread. Between 1913 and 1940 (and presumably beyond), the procedure was used almost universally in English prisons. In their register, the Commissioners recorded that force-feeding had been performed in fiftyone prisons. In 1913, England had a total of sixty-one prisons; a figure reduced to thirty-eight by 1940 . The almost universal use of force-feeding suggests that a consensus existed among prison medical staff on the usefulness of feeding in tempering protest. Figure 6.4 details the number of times force-feeding was performed in the nineteen prisons with the highest number of incidences. It demonstrates that hunger strikes were more likely to occur in prisons with higher bed numbers, naturally reflecting the larger number of prisoners resident in these institutions who might potentially refrain from eating. In 1913, Parkhurst Prison could accommodate up to 818 prisoners, an institution where force-feeding was performed 90 times. Prison doctors performed 71 force-feedings in Manchester Prison which could accommodate 1203 prisoners in 1913. Similarly, in 1913, Liverpool, Wormwood Scrubs, Pentonville, Dartmoor, and Wandsworth all contained over 1000 beds. With the exception of Wandsworth, over thirty hunger strikes were responded to with force-feeding in each of these institutions. This compares with smaller institutions such as Bristol 


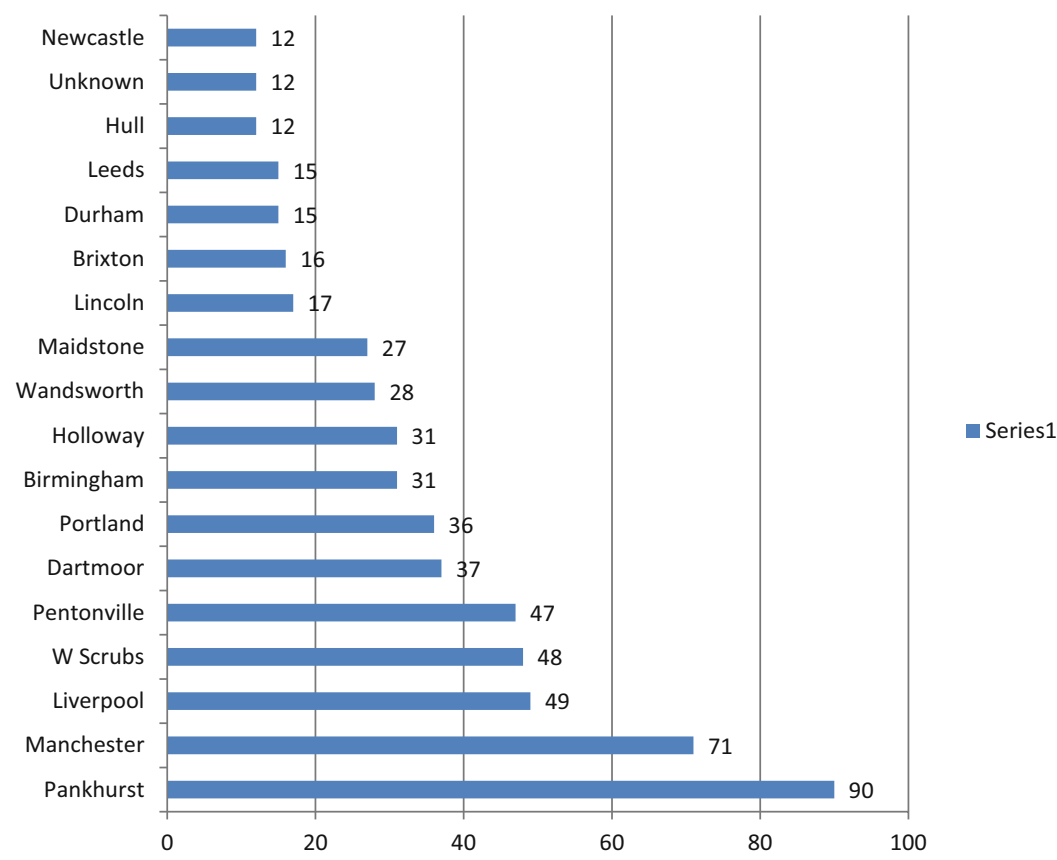

Fig. 6.4 English prisons in which incidences of force-feeding occurred, 1913-40 (Source: Kew, PCOM 2/465, 'Register of Criminal Prisoners on Hunger Strike (other than Suffragettes)', 1913-40)

Prison that could accommodate 303 prisoners and witnessed only 3 forcefeedings. Similarly, Exeter Prison could accommodate 185 prisoners, an institution where prison doctors performed 4 force-feedings. ${ }^{39}$

The number of force-feedings carried out in individual prisons inevitably depended upon the number of prisoners in residence who chose to hunger strike. Yet smaller prisons tended to be staffed by part-time medical officers. ${ }^{40}$ This contrasts with larger prisons such as Wormwood Scrubs that contained a specialised surgical unit, superior staffing arrangements, and even a psychiatric unit by the 1940s. ${ }^{41}$ Those prisons fortunate enough to contain sufficient medical resources and dedicated full-time staff were no doubt more able to use available resources to engage in prolonged feeding periods that, in extreme cases, involved three feedings each day for a number of months. The longest feeding periods typically took place in large institutions such as Wormwood Scrubs where, between 
1914 and 1915, a prisoner named Humphries was fed 290 times, a period of approximately 96 days. ${ }^{42}$

The overall impression that emerges from the Commissioner's register is that force-feeding remained relatively common in English prisons even despite the vivid accounts of brutality, pain, and psychological trauma that had been brought to public attention by militant suffragettes and the recommendations made against the practice in Ireland at the inquest that followed Ashe's death. A large proportion of hunger strikers were subjected to force-feeding; a procedure that brought their protests to an abrupt end, as evidenced by the vast majority of hunger strikes not lasting beyond a day of feeding. A preference for using intrusive technologies reinforced the sense of imposed discipline felt by protesting prisoners while, from the perspective of the prison doctor, strengthening their deterrent value. The use of force-feeding was geographically spread, although it was used most often in larger prisons equipped with extensive medical facilities. Legal action was rarely taken against prison doctors and proved unsuccessful.

\section{Why Hunger STRike?}

What motivated convict prisoners to hunger strike? In their register, the Commissioners recorded various reasons for refusing to eat. Post-war journalistic reportage sheds further light on the multiplicity of factors that encouraged hunger striking. Figure 6.5 collates the motivations noted by the Commissioners (no reason was recorded in 339 incidences or $29 \%$ of all hunger strikes). In 1920, medical staff at Liverpool Prison force-fed Michael Brennan 138 times. Throughout his forty-six days of being forcefed, Michael provided no rationale for refusing food. Incidences such as these provide the most puzzling accounts of hunger striking, although one plausible explanation is that prison staff sought to conceal sources of prisoner disgruntlement from the Commissioners. ${ }^{43}$

Moreover, the recorded motivations undoubtedly reflected the perceptions of institutional staff towards prisoners. While some reasons (such as conscientious objection) are relatively straightforward to decipher, vaguer explanations (such as malingering and suicidal tendencies) need to be cautiously interpreted as potential expressions of the derogatory attitudes of prison staff towards certain prisoners rather than accurate representations of personal motivations. The frequent assigning of mental illness as a rationale for hunger striking affirms this point. Between 1913 and 1940, the Commissioners noted seventy-eight hunger strikes somehow 


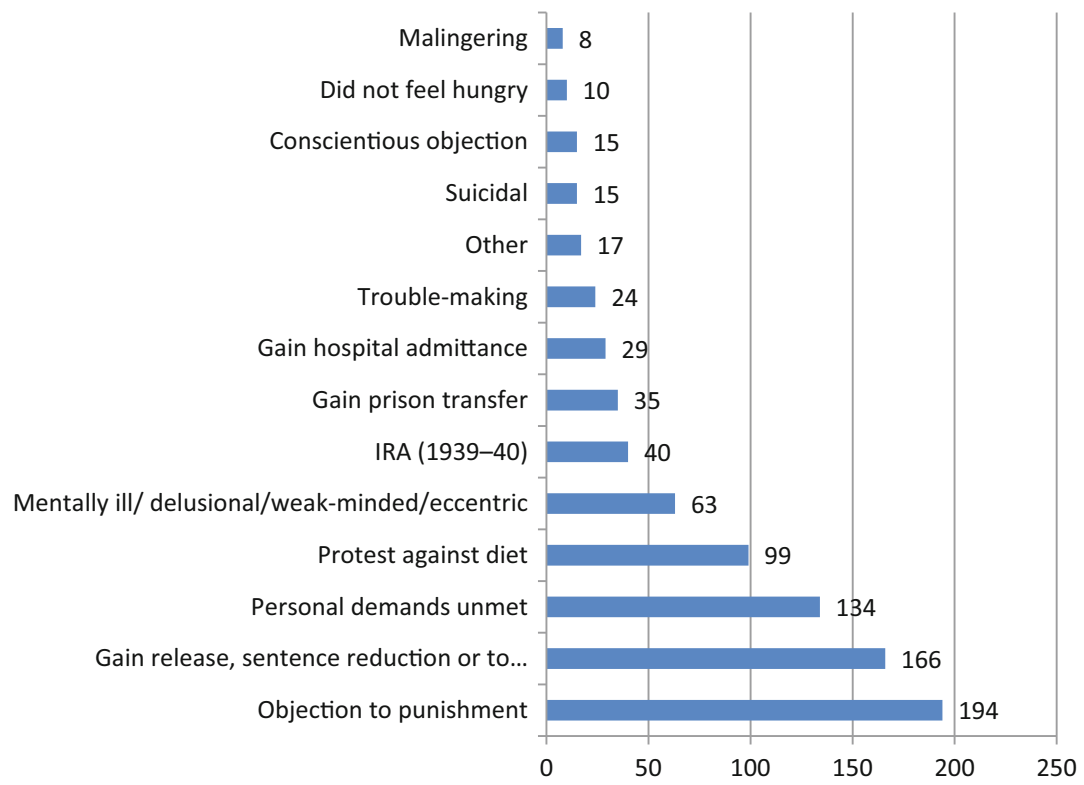

Fig. 6.5 Recorded motivations for hunger striking in English prisons, 1913-40 (Source: Kew, PCOM 2/465, 'Register of Criminal Prisoners on Hunger Strike (other than Suffragettes)', 1913-40)

connected to mental instability. ${ }^{44}$ Yet, historically, the labelling of mental disorder was framed by broader socio-cultural presumptions made by physicians about certain character types or social groups. In the 1910s, medical authors had condescendingly diagnosed militant suffragettes as hysteric to explain their uncharacteristic masculine tendencies towards violence ${ }^{45}$ When viewed retrospectively, this classification reveals more about the gendered perceptions of doctors who took to writing than the actual psychological condition of suffragettes.

Twentieth-century prison doctors increasingly involved themselves in the issue of mental health. In the previous century, the British medical community had expressed a growing concern with understanding the psychological makeup of criminals. They often depicted criminals as physically and psychologically different, as set apart from morally sound individuals by their physical and mental condition. ${ }^{46}$ In this context, prison medical staff found themselves well-positioned to observe and report on the psychological aspects of crime. ${ }^{47}$ Prison doctors tended not to be psy- 
chiatrically trained. Nonetheless, they routinely engaged in mental health diagnosis. ${ }^{48}$ They also shared a common propensity to label disruptive patients as insane to support ongoing confinement or to transfer bothersome inmates to an asylum. ${ }^{49}$ Yet by emphasising the natural mental predisposition of criminals prior to institutionalisation, medical staff proved less attentive to the potential psychological and emotional effects of the prison environment itself. ${ }^{50}$

In their register, the Commissioners recorded sixty-three hunger strikes seemingly connected to psychiatric disorders ranging from severe (suicidal) to mild (eccentricity). ${ }^{51}$ Many of these diagnoses were relatively vague, including 'delusional' or 'weak-minded'. ${ }^{52}$ Prison doctors designated suicidal impulse as the reasoning behind a further fifteen episodes of food refusal and insinuated that a number of other protestors harboured a desire for death. ${ }^{53}$ But, were convict hunger strikers suicidal? In 1918, Richard Pugh initiated a hunger strike at Winchester Prison due to 'the futility of things'. Richard was force-fed five times before prison officials transferred him to Pentonville Prison. At Pentonville, Richard initiated a second hunger strike brought to an end after three feedings. In 1929, prison doctors interpreted a hunger strike pursued by James Henry Marsh as an expression of his desire to die. James endured nine force-feedings before ending his protest. During the First World War, German prisoner of war Leopold Vieyra was force-fed thirty times in Pankhurst Prison after initiating a hunger strike reportedly connected to his mental depression. A further hunger striker stated that he was 'tired of coming to prison year after year and would be better dead' ${ }^{54}$

In reality, it seems highly unlikely that prisoners would have chosen self-starvation as a method of suicide. Suicidal prisoners ended their lives in far more determined ways. They attached themselves to gas brackets and asphyxiated themselves ${ }^{55}$ or hanged themselves in their cells with their belts. ${ }^{56}$ Speedier and more efficient options were available for prisoners who wished to end their life than a slow period of self-imposed starvation. ${ }^{57}$ Moreover, force-feeding was an inadequate response to mental depression. When viewed retrospectively, these remarks can be viewed as comments made by prisoners about the psychologically harmful effects of prison life interpreted, or presented, by prison doctors as expressions of suicidal intent. Undoubtedly, prison life had a wearing effect on mental health. Prison suicide persisted as a pertinent problem throughout the twentieth century. Yet prison doctors and politicians typically made recourse to the argument that higher levels of mental illness existed 
among criminal types, carefully skirting the issue of whether prison life itself fostered suicidal tendencies. ${ }^{58}$ In contrast, critics, such as Hobhouse and Brockway, insisted that environmental aspects of prison life played an equally important role in encouraging suicide. ${ }^{59}$ Nonetheless, prisoners were denied the opportunity to assert their right to live in humane conditions that did not tarnish their emotional well-being. Those who refused food on this basis were force-fed rather than offered psychiatric care.

On one occasion, the attribution of suicidal intent allowed prison doctors to cast blame for a death suspiciously associated with force-feeding on to a hunger striking prisoner. In 1912, Steinie Morrison arrived at Pankhurst Prison. Steinie had been convicted of murder and sentenced to death, although his sentence had been commuted to life imprisonment. Throughout almost a decade of imprisonment, he maintained his innocence. In 1921, Steinie died in Pankhurst Prison. At the inquest that followed, prison doctors recollected that Steinie refused food immediately upon arriving at the prison and needed to be restrained due to his violent tendencies and persistent suicide threats. At the inquest, the doctors suggested that Steinie had gradually reduced his food intake since 1917 with the intention of slowly ending his life. When doctors threatened him with a feeding cup, Steinie would intimate that he intended to cut his own throat. In response, prison medical staff had removed Steinie to a padded cell and regularly force-fed him; an act vigorously resisted by their patient. In 1921, Steinie died unexpectedly from a heart problem.

A coroner present at the inquest remained unconvinced that Steinie had died from years of gradually cutting back on food and refused to sanction the cause of Steinie's death to suicide through self-starvation. The jury returned a verdict of death from syncope and aortic disease aggravated by food abstinence. ${ }^{60}$ Evidently, the jury refused to fully take on board insinuations made by the prison medical staff about Steinie's suicidal intent. Yet the inquest is also noteworthy for the lack of scrutiny of the use of force-feeding and its potential role in undermining Steinie's health and precipitating a fatal heart condition (a link forged by militant suffragettes and Irish republicans). It is unclear whether the prison doctors knew full well that their feeding practices had weakened Steinie's heart. What is clear is that Steinie was a particularly troublesome and violent man who was out of favour with the prison doctors who, he claimed, regularly plied him with laxatives to incapacitate and punish him. ${ }^{61}$ Given that force-feeding held coercive purposes, it seems plausible that the procedure was regularly performed on him and played some role in his death. 
Depicting Steinie as suicidal allowed medical staff to present his death as an unfortunate outcome of his refusal to eat rather than their forceful attempts to feed him. Steinie's plight attracted comparatively little public attention in comparison to Thomas Ashe's politically charged death. Public sympathy was unlikely to be forthcoming for a convicted murderer. In fact, in this period, a relative lack of public sympathy towards nonpolitical hunger strikers allowed the use of coercive techniques to remain mostly hidden from public view, at least until the post-war period. Michael Ignatieff suggests that it was essential that the infliction of punishment conserved its moral legitimacy in the eyes of the public. ${ }^{62}$ In this instance, prison doctors achieved this by portraying Morrison as suicidal.

Prison doctors could not convincingly attribute all hunger strikes to mental illness. Many prisoners protested in objection to the physical ramifications of prison life, once again asserting their right to health. For instance, many revolted against the sparse dietary arrangements available, seeing this as a threat to their physical integrity. ${ }^{63}$ Between 1913 and 1940 , ninety-nine prisoners refused to eat in protest against the unpalatable diet on offer in prisons. A further ten simply stated that they did not feel hungry. The Commissioner's register is replete with brief statements made by prisoners who provided their reason for hunger striking as 'I can't eat that bread', 'I cannot eat it', and 'poison'. ${ }^{64}$ In 1921, John Moran abstained from eating in Pankhurst as he felt unable to face the inedible prison food. Denying John the right to express dissatisfaction with prison food quality, prison doctors force-fed him nineteen times before he decided to resume eating. Four years later, Thomas Jameson abstained from food for similar reasons and was force-fed twenty-six times. ${ }^{65}$

Prison dietaries were notoriously meagre, having been devised in the nineteenth century to deter criminal activity and contribute to the coercive ethos of the prison. Many officials insisted that prison diets needed to be punitive and advocated providing the bare minimum of food required by the human body to avoid death. ${ }^{66}$ In 1921, Evelyn Ruggles-Brise, Chairman of the Prison Commission, claimed that prison diets had dramatically improved since the Victorian period, meaning that prisoners no longer lost weight or became susceptible to illness. The principle of a punitive diet, he insisted, no longer existed.$^{67}$ In contrast, Hobhouse and Brockway retorted that prisoners felt perpetually hungry and that catering staff prepared meals using poor quality food items. Prisoners, they suggested, were worryingly prone to indigestion, diarrhoea, skin rashes, and constant constipation. ${ }^{68}$ In 1944, the Medical Research Council concluded 
that prison dietaries lacked Vitamins $\mathrm{A}$ and $\mathrm{C}$ and recommended fuller provisions. ${ }^{69}$ Three years later, 105 prisoners at Pankhurst Prison staged a mass protest related to poor quality food. ${ }^{70}$ Some improvements were made in 1959. ${ }^{71}$ Yet prison diets continued to spark debate. In 1972, Northern Irish MP, Bernadette Devlin, quizzed the Under-Secretary of State for Home Affairs, Mark Carlisle, on the amount being spent on food in prisons. It transpired that $£ 1.20$ a week was being spent on feeding prisoners in Leicester Prison, a figure that compared unfavourably to the $£ 2.50$ per week being spent buying food for the prison dogs. ${ }^{72}$

Given this context, it seems unsurprising that prisoners protested against sparse, often unpalatable, food provisions, sensing an undermining of their right to nutritional and physical health. However a small number of hunger strikes arose due to a lack of sensitivity among prison staff to certain dietary requirements or preferences. When conscientious objector Fenner Brockway was imprisoned in Wormwood Scrubs during the First World War and requested a vegetarian diet, the doctor shook his head. A change to the dietary arrangements was only allowed if a prisoner showed severe weight loss. Angered, Fenner petitioned the Home Secretary and began a partial hunger strike by refraining from eating meals containing meat. Approval of a vegetarian diet was granted three months later. According to Fenner, the vegetarian option proved popular among prisoners accustomed to eating coarse meat items. 'Hardened criminals', Fenner later claimed, 'including a man who was serving a year for hitting his wife on the head with a poker, assured the Governor that their consciences would no longer allow them to eat meat'. ${ }^{73}$ Notably, Fenner was opposed to the idea of threatening to take his own life on the grounds that he was a pacifist and should not kill anyone, even himself. ${ }^{74}$

Although most prisoner protests relating to food proved unnewsworthy, there was one exception. In 1974, the Daily Mirror reported on its front page that a hunger striking Jewish prisoner named Keith Baillie had been force-fed for a staggering 800 days. Keith was serving a fifteen-year sentence for robbery and firearm possession. He had initially refused to eat after catering staff accidentally served him kosher margarine on a spatula also being used to dispense non-kosher margarine. The prison officials swiftly rectified the catering situation. Nonetheless, Keith continued to protest and issued a writ to the Home Office demanding that the Commissioners enforce their own regulations and grant him the right to observe his religion. Prison medical staff transferred Keith to a psychiatric wing. Although Keith occasionally accepted food from a cup 
with a sprout, he was force-fed for over two years. ${ }^{75}$ When Keith's plight began to attract public attention, Labour MP, Jock Stallard, called for an independent inquiry to look into the question of artificial and forcefeeding with a view to discussing alternatives and 'abolishing this barbaric process' ${ }^{76}$

Keith's predicament indicates an inherent lack of sensitivity among prison medical staff towards the religious needs of prisoners from ethnic minority backgrounds while revealing the complex power relations that surrounded prison food. It also indicates that medical staff continued to define protesting prisoners as psychologically troubled, irrational, and in need of therapeutic intervention. In fact, it was not unknown for prisoners who protested against prison food to have their behaviour psychiatrically diagnosed. In 1960, Lancashire fusilier, Alan Robinson, went on hunger strike at Wellington Barracks, Bury. Alan was given discharge on medical grounds and transferred to Moston Hall Military Hospital where a psychiatrist visited him and persuaded him to eat. Alan had initially protested against the poor quality of army food. ${ }^{77}$ Prison diet formed an important part of the broader institutional nexus of power relations that structured the interactions between prisoner and prison staff. ${ }^{78}$ From the perspective of prison officials, the imposition of restricted, often meagre, food servings helped to rehabilitate behaviour by promoting personal restraint and encouraging reflection on the loss of privileges found in the outside world. Yet many prisoners refused to acknowledge the moral acceptability of meagre institutional feeding. Throughout the twentieth century, food remained a key bone of contention and provided a regular basis for prisoner protest.

The issue of physical well-being manifested in a number of other hunger strike scenarios. Many prisoners felt that prison doctors paid inadequate attention to their medical needs. Issues such as dentures could prove particularly sensitive and encourage prisoner dissent. In 1913, John Riley went on hunger strike at Dorchester Prison to protest against the slowness of the prison officials in providing him with a denture. Despite being in agonising oral pain, John was force-fed twenty-one times. ${ }^{79}$ In the early twentieth century, prisoners had to pay for medical services such as dentures. If they were not in credit, then prison staff typically ignored their problems ${ }^{80}$ Teeth problems appear surprisingly frequently in twentiethcentury prison autobiographies. ${ }^{81}$ More generally, it was common for prison doctors to disbelieve in their patient's symptoms, to presume that all prisoners were inherently dishonest and prone to malingering. ${ }^{82}$ The 
Commissioners recorded twenty-nine cases of food refusal disregarded by prison doctors as efforts to gain hospital admission (and secure a fuller diet) by feigning illness. ${ }^{83}$ Whether or not these individuals were suffering from genuine complaints, or if they staged hunger strikes to provide moral evidence of their sincerity, is unclear.

In addition, many hunger strikers sought to challenge the excessive levels of punishment which they saw as being inflicted on their bodies and minds. In the early twentieth century, prisoners could be punished-often for relatively trivial offences - with severe dietary restriction, isolated periods of solitary confinement, flogging, physical restraint, and visit reductions. Indeed, the chief aim of the convict prison system was to deter through the bureaucratic enforcement of rules and regulations. ${ }^{84}$ Prison officers themselves could be subject to punishment if they failed to report breaches of discipline, a system that encouraged staff members to maintain a punitive environment. Yet many prisoners considered the strict and complex web of prison rules pinned to the wall of their cells impossible to adhere to, and sensed that they were liable to victimisation and punishment at any given time. ${ }^{85}$

The Commissioners noted 194 prisoners who staged hunger strikes in protest against excessive punishment. In 1916, William Roberts, convicted for burglary at Manchester Prison, was force-fed fifty-five times after staging a hunger strike to protest against being punished without proper cause. ${ }^{86}$ Alfred Tragham was force-fed twenty-five times at Pankhurst after protesting against excessive punishment. ${ }^{87}$ In 1923, Thomas Clarke initiated a hunger strike in Birmingham for the reason that 'the officers are always on to him.' He agreed to resume eating upon observing the tube being prepared for his feeding. ${ }^{88}$ In 1965, Thomas Wisbey, one of the Great Train Robbers, went on hunger strike in Leeds Prison as he felt that he was being subject to harsh treatment by prison staff who were angered by a recent escape from Wandsworth made by Ronald Biggs. ${ }^{89}$ Throughout the late 1960s, Thomas staged a number of hunger strikes but called off most of these following a telephone conversation with his wife..$^{90}$ Thomas claimed that prison officials had placed him in solitary confinement for twenty-three hours a day, despite the fact that he had not been causing trouble. His brother publicly stated that 'the only way he could hit back and draw attention to what is happening was to go on hunger strike.' His solicitor added that Thomas had been a model prisoner. ${ }^{91}$ Evidently, hunger striking provided one means by which prisoners could re-assert their bodily integrity by challenging the strict punishments in 
place to impose discipline. They perceived a right to be able to reside in prisons without suffering victimisation. Yet their protests tended to be responded to with a further punishment: force-feeding.

In addition to asserting their right to health and freedom from excessive punishment, many prisoners went on hunger strike to secure certain concessions. Between 1913 and 1940, the Commissioners noted 134 hunger strikes among prisoners whose requests had been refused. Some sought transfer to an alternative prison. In 1926, John Kenny Williams, imprisoned for larceny, instigated a hunger strike after his petition to be moved to Cardiff Prison was refused. He was force-fed twelve times. ${ }^{92}$ In 1977, imprisoned singer and brothel owner, Janie Jones, went on hunger strike to protest against plans to transfer her from Holloway to Styal prison, a semi-open women's institution in Cheshire. Janie refused food for twenty-seven days until Lord Longford agreed to visit her. Her protest was predicated on the basis that she would be unable to handle her business affairs in Cheshire. ${ }^{93}$ Other protests arose for deeply personal reasons, part of an attempt to express and maintain individuality in an environment based upon conformity and a loss of identity. When, in 1933, the prison governor removed family photographs from the cell of a man in Cardiff Prison, the prisoner went on hunger strike for seventeen days and made representations to the Home Office. ${ }^{94}$ Issues relating to familial life and access to the outside world caused persistent contention. In 1969, six prisoners at Leicester Prison went on hunger strike in solidarity with four other prisoners at Durham prison who had protested against Home Office regulations that required visitors, including wives, to provide photographic identification prior to visiting category A prisoners. ${ }^{95}$

Evidently, hunger striking offered an important avenue of resistance against the rigid systems of physical and psychological control that characterised the twentieth-century prison environment. Prisoners protested for a plethora of reasons, including objections to prison food, a refusal of prison officials to meet medical or personal demands, and to rally against harsh punitive regimes. Food refusal allowed prisoners to assert their autonomy. Nonetheless, the majority of prisoner efforts to assert their perceived rights by abstaining from food were abruptly halted with force-feeding; a procedure intended (often successfully) to restore a prison regime which demanded that food was to be consumed at rigidly prescribed meal times. Prison officials tended to approach hunger striking as a behavioural issue, a problem that could be rectified by imposing physical force. Although force-feeding tended to re-align prisoner behaviour to the expected norms 
of the prison, the procedure less successfully resolved issues relating to mental health, dietary concerns, and institutional intimidation.

\section{Successful Hunger Striking}

Throughout much of the century, public attention was rarely drawn to prisoner welfare concerns apart from during well-publicised episodes of prison rioting. ${ }^{96}$ Yet a small number of force-fed prisoners did manage to capture the attention of politicians and journalists. The experience of most convict hunger strikers confirms Pethick-Lawrence's claim that hunger strikers needed firm resolution and conviction in their cause if their protests were to succeed. Prisoners also required the physical and mental resolve to withstand force-feeding. It was these prisoners who staged the most successful, newsworthy protests. Most hunger strikers, when faced with the menacing prospect of the stomach or nasal tube, chose to resume eating. Yet some prisoners did endure sustained bouts of force-feeding and tended to share particular motivations that differed from other hunger strikers. Figure 6.5 demonstrates that 166 convict prisoners went on hunger strike between 1913 and 1940 with the agenda of securing release or a sentence reduction. This prisoner group was more likely to persevere with a hunger strike and willingly submit their bodies to force-feeding. Seventeen prisoners endured over one hundred days of being force-fed as they held considerable faith in their moral cause. Between 1913 and 1915 , a prisoner at Wormwood Scrubs named Humphries instigated two hunger strikes. Humphries was force-fed 138 times (for approximately 46 days) and a further 290 times (approximately 96 days). By enduring forcefeeding, Humphries sought to demonstrate his innocence. ${ }^{97}$

The longest incidence of force-feeding recorded by the Commissioners occurred in 1935 when Henry Gordon Everett, imprisoned for attempted suicide, refused food in protest against the length of his conviction. As part of his moral crusade to secure release, Henry endured 474 feedings with a nasal tube, a period lasting approximately 15 months. ${ }^{98}$ Henry later claimed that his solicitors had encouraged him to plead guilty against his own inclination and better judgement. In a public statement made upon release, he asserted that:

In consequence of the injustice I adopted a hunger strike, continuing the same till my discharge nearly six months later ... I was kept alive by forcible-feeding, and not discharged until the last possible day of my sentence. I can bear the 
injustice no longer and also feel it my duty to register a protest against, and in defiance of, the antiquated and fallacious suicide laws which deny a poor person to die in a land of peace and plenty. ${ }^{99}$

Some decades later, Ronald John Barker commenced a particularly provocative hunger strike to draw attention to his wrongful confinement. In 1970, Ronald was sentenced to four-years imprisonment on a charge of robbing two elderly women of eighty pounds in Louth, Lincolnshire. Barker went on hunger strike at Armley Prison, Leeds, to protest his innocence. Ultimately, he endured what journalists described as a record hunger strike of 370 days (although Henry Gordon Everett's protest had in fact lasted longer). Upon being released after a successful retrial, Ronald's solicitor described him as 'a very tired, very happy man, who has to face the problem of eating normally again after being fed through a tube for 370 days' ${ }^{100}$

Everett and Barker's cases, separated by four decades, demonstrate the potential usefulness of hunger striking in challenging confinement, but only if force-feeding could be endured. Henry, who had swallowed 200 pills prior to his arrest, refuted the state's authority to dictate to him that he had no right to decide when to die. In that sense, Henry firmly believed in his innocence. Similarly, Ronald resolutely believed in his guiltlessness, a conviction that bolstered his determination to endure a lengthy period of being force-fed. Both individuals ultimately attracted public attention to their particular cases by remaining resilient and resisting coercive efforts made by prison medical staff to bring their behaviour into line. They presented their endurance of pain as itself validation of their innocence; as a necessary step taken to convince the public of their right to freedom.

Notably, at Ronald Barker's retrial, Justice McKenna advised the jury:

The accused told you on Friday that he has been on hunger strike. I would be cautious, if I were you, about concluding that the accused is innocent from his having gone on hunger strike ... many who have been rightly convicted have persisted in saying that they are innocent, and it is conceivable that such men should try to persuade others of their sincerity by refusing to eat. ${ }^{101}$

This cautious statement reflected a sense felt by judges that a long hunger strike might indeed be publicly viewed as a sign that the prisoner had repented enough or that he or she was innocent and needed to be released. The fact that a prisoner had demonstrated the conviction to 
persevere with a protest in the face of force-feeding could influence the verdict of a trial or retrial. In 1957, Alfred George Hinds was force-fed at Pentonville. MPs raised questions in the House of Commons about why Alfred appeared so willing to starve himself to death rather than accept the justice of the verdict placed upon him. Could it be that he was innocent? ${ }^{102}$ After a tenth day of force-feeding, over thirty MPs agreed that a Select Committee should inquire into the issue of whether a miscarriage of justice had taken place. ${ }^{103}$ Alfred subsequently gained notoriety and minor celebrity status after escaping from a number of high-security prisons throughout the 1960s.

The sense of injustice felt by hunger strikers depended upon the prisoner's perception of the relative seriousness of their offence which, in some instances, clashed with the mainstream views of society. In May 1976, Robert Relf staged a hunger strike in Stafford Prison. Robert, aged fifty-one, was an ex-Commando and ex-bodyguard to prominent neoNazi Colin Jordon. He had spent the 1960s, while serving as a member of the British National Socialist Movement, daubing race hate messages in Leamington Spa, including 'Integration Means Mongrelisation'. Controversially, he had also attempted to launch a British branch of the Ku Klux Klan. ${ }^{104}$ In 1976, Robert was sentenced to imprisonment for refusing to remove a racially offensive sign that advertised his house as being for sale 'to an English family only'. The sign remained in his window, overlooking a garden covered with Union Jacks. Robert was prosecuted and imprisoned under the Race Relations Act. After forty-five days of refusing to eat, Robert's protest began to receive national coverage, at which point, a judge authorised his release. Robert's supporters cheered as he left the court singing 'Rule, Britannia!'. ${ }^{105}$ During the hunger strike, Robert's wife, Sadie, regularly visited her hunger striking husband and later told friends that he was shaking and had lost a lot of weight. ${ }^{106}$ Robert's belief in his racist opinions remained firm, even if it clashed with the ethos of an increasingly multicultural society.

Numerous other prisoners staged protests that garnered publicity who did not see their crime as being wrong. Some prisoners made a stronger moral case than other. Throughout the 1960s, Rosalie Jayson commenced a ten-year harassment campaign directed at her bank manager, Bernard Hewett, after two of her cheques were dishonoured. Described by the Daily Express as 'an insoluble problem', Rosalie was continuously arrested and re-imprisoned for committing acts such as breaking 125 panes of glass at Jayson's home. Upon entering prison in 1969, she refused food in pro- 
test against injustice. ${ }^{107}$ In 1962, Russian-born celebrity health enthusiast Barbara Moore fasted in protest against being imprisoned for contempt of court. Her consultant physician, Michael Ashby, confirmed to the press that the prison doctors did not intend to feed Barbara due to her weak health (and not because of her celebrity status). The Home Office insisted that the question of force-feeding would be decided by the prison authorities. Barbara was reputed to be a breatharian (an individual who believes that humans can subsist without food and sustained soley by prana-the vital life force in Hinduism). She threatened to kill herself by holding her breath if the prison doctors tried to feed her. ${ }^{108}$ Barbara's physician, Michael Ashby of London Whittington Hospital, publicly stated that she should be allowed to carry out her threat to fast until death. In the Daily Mirror, Ashby suggested that if she dies I shall not blame myself. It may be a doctor's duty to save life, but it is also his duty not to assault a patient. To feed this patient forcibly would constitute an assault,' However Ashby believed that force-feeding would not conflict with his medical ethical inclinations if Moore lost consciousness or became too weak to protest. 'In such circumstances', he suggested, 'a patient would then not be protesting. 109

Moore's case demonstrates that it was common for the most persistent, troublesome hunger strikers to gain public notoriety. Confirming this point, earlier in the century, Inspector John Syme generated a considerable amount of public debate and paperwork for the Home Office. ${ }^{110}$ In 1909, two police constables were disciplined for having arrested and detained a number of individuals at Gerald Road Police Station, London, without sufficient evidence. Syme, who was duty officer at the time of the incidence, supported the two constables to the annoyance of his senior colleagues. A disciplinary hearing followed and Syme was punished with a transfer to Fulham Police Station. ${ }^{111}$ Perturbed at his treatment, Syme made allegations of tyranny against the chief inspector of Gerald Road, submitted insubordinate reports, and expressed his intention to carry his grievances to Parliament. At this point, Syme was dismissed from the police force. In response, he formed the National Union of Police and Prison Officers. As part of his crusade for justice, Syme also established a publication, described by his former colleagues as a 'disreputable journal', that took issue with the police commissioners and officers who disagreed with his aims of his union. ${ }^{112}$

Throughout the following decade, Syme was imprisoned numerous times for acts of civil disobedience. His plight attracted considerable public 
attention. In June 1919, in a broader discussion of whether Syme, who had gone on hunger strike and been released, would actually return to the prison under the terms of the Cat and Mouse Act, Sir John Rowlandson privately wrote that 'the John Syme case was the great cancer at the root of the present police trouble.' ${ }^{113}$ In April 1920, Syme smashed a fanlight hanging outside the residence of the prime minister. He was swiftly arrested and remanded for a week in custody at Brixton Prison before being released after six days of hunger striking. Rather than attend the police court, Syme re-committed the offence and also threatened to assault the king or queen at an opportune moment, his intention being to create a public scandal to draw attention to his grievances. ${ }^{114}$ According to a police officer who encountered Syme loitering outside the House of Commons, the ex-inspector had announced that he would go on hunger strike upon his next arrest, 'in spite of the fact that he cannot be forcibly fed due to the curious formation of his body and that he is now fully prepared to accept the alternative of death'. ${ }^{115}$

In a confidential report written in relation to an appeal made by Syme in May 1920, Chief Constables H. Morgan and J. Billings described the ex-inspector as 'a man of morose and obstinate disposition, self-opinionated and of extreme views. He was always opposed to discipline and resented its application to himself or others. His attitude was that of a person who believed the whole fabric of the empire was saturated with wrongs that wanted setting right.' The chief constables added their opinion that Syme was a 'misguided, self-deluded man who perhaps conscientiously believed he had a genuine grievance to ventilate and get put right'. ${ }^{116}$ Yet, regardless of whether Syme's views were extreme or simply posed a threat to the established structure of the police service, there is little doubt that he possessed unwavering conviction. This encouraged him to instigate a number of hunger strikes during his repeated imprisonments.

Despite force-feeding remaining relatively common in English prisons, it took a high profile case such as Syme's to ignite political and public discussion. In 1922, a heated debate took place in the House of Commons between Labour MP, Charles Ammon, and Home Secretary, Edward Shortt, on the matter. Ammon insisted that Syme was being tortured by being constantly released and re-imprisoned under the Cat and Mouse Act, an argument that echoed claims made by the suffragettes some years earlier. Referring back to the events of the previous decade, Ammon maintained that 'the passage of time has proved that the suffragettes are, after all, quite respectable members of society', adding that the torture which 
the Act had originally been directed at militant female prisoners was now being directed to individuals such as Syme who, Ammon suggested, was a respectable man who had been unjustly treated. In his curt response, Shortt stated:

The doctors say you cannot efficiently forcibly-feed him. I protest against the suggestion that we are torturing a man who deliberately persists in starving himself. We provide him, when he is in prison, with good, wholesome, tasty food. He will not touch it. That is not our fault. I protest against the suggestion that we are responsible for anything he suffers. He is absolutely responsible himself. I am told he is now hunger striking out of prison. We have no concern with that. If he does not eat out of prison, he must take the consequences himself. ${ }^{117}$

In August 1923, Syme fell ill in Pentonville while pursuing a hunger and thirst strike. Although he was temporarily released under the Cat and Mouse Act, he informed his medical officer that he intended to return to the Home Office to break another pane of glass and 'make a clean job of it'. However, Syme was too weak to leave his house. Kept under close police surveillance, Syme was re-arrested after sixteen days, after which he immediately staged a further hunger and thirst strike that lasted for eight days. In total, Syme initiated twenty-seven hunger and thirst strikes. ${ }^{118}$ Eventually, in 1925, he was transferred as a pauper lunatic to the London County Mental Hospital. ${ }^{119}$ Syme's plight provides a further example of the potential power of food refusal in drawing public and political sympathy to alleged incidences of injustice. Ultimately, Syme's wish to be re-instated to the police force proved unsuccessful. Nonetheless, in subsequent decades, Syme was informally recognised as a victim of bullying and harassment and received a police pension. ${ }^{120}$

Prisoners could also be inflamed with an unwavering conviction in a moral, rather than personal, cause. These instances also attracted public attention. In 1969, five imprisoned parents, including J. P. and Councillor Bette Bell, went on hunger strike in Winchester and Holloway after being imprisoned for protesting against increased admission charges to a public park. Their protest encouraged Chancellor of the Exchequer, James Callaghan, to order a police report into the imprisonments, an act supported by the Lord Mayor of Portsmouth and the National Council for Civil Liberties. One prisoner, Sylvia Humphreys, publicly claimed that her prison doctor had threatened to force-feed her if she continued refusing 
food although a Home Office spokesperson denied this. ${ }^{121}$ A consortium of other prisoners undertook hunger strikes as part of their broader beliefs about the prevailing socio-economic system in place in western society. These included animal rights activists (who also refused to wear prison clothes made from animal products) $)^{122}$ and language rights protestors who demanded a right to address a court in Welsh. ${ }^{123}$

Predictably, prison medical staff were prone to diagnosing prisoners whose ideologies failed to conform to those generally shared in mainstream society as mentally unstable. While force-feeding made little difference in adjusting the political ideologies and social outlook of this type of prisoner, it did help to temporarily subdue the institutional disruption which they were prone to causing. During the First World War, J. Sidney Overbury, dismissed as 'eccentric' by his prison doctor, was force-fed forty-three times at Wormwood Scrubs Prison. Overbury could not be diagnosed with a psychiatric condition severe enough to warrant asylum admission. Yet the prison doctor's labelling of eccentricity suggests that he perceived, or chose to present, his patient's decision to refuse food as a product of psychological instability, a problem requiring rectification with a stint of force-feeding to bring the prisoner's behaviour into line. ${ }^{124}$

Overbury was imprisoned with Tom Ferris. Both were members of a small group of families who had lived closely together in Beeston, Yorkshire, who subsisted on the profits of a cottage knitting industry. ${ }^{125}$ The Beeston Brotherhood was constituted on Tolstoyian Christian anarchist principles that rejected the principle of state authority. Accordingly, when Overbury and Ferris were initially imprisoned in 1915 for distributing leaflets in contravention of Regulation 27, they both refused to eat prison food on the basis that it had been purchased with institutional, and by extension, state funds. Both Overbury and Ferris rejected the principle of taxation and viewed prison food as property stolen from the financial resources of the population. After a number of days of correspondence between the Commissioners and prison officials, Ferris conceded to eat food but only if it had been prepared by his wife and if permission was granted for him to continue writing his book on religious principles while imprisoned. Under-Secretary of State in the Home Office, Edward Troup, granted permission on medical (psychiatric) grounds. ${ }^{126}$ The prison governor looked upon Ferris as suicidal - as a 'religious maniac' and privately discussed the possibility of certifying him with members of the Home Office. ${ }^{127}$ Lord Leonard Courtney entered into the debate by 
adding 'get them out of hospital as soon as possible in the hope that the episode may die a natural death'. ${ }^{128}$

Police re-arrested Overbury in the following year for disobeying orders. Upon refusing food, he was force-fed. The medical officer described Overbury as insane but doubted the possibility of being able to certify him during such a short term of imprisonment. In a letter written to Brigadier General Childs, he stated 'the man is undoubtedly a religious crank or maniac and I should say there was no possibility of making a soldier of him. I suggest that it is worth considering whether it would not be wiser to let him alone when he is released and not persevere with him. ${ }^{129}$ In June 1925, Ferris re-appeared in Leeds Prison after being convicted of assaulting a police officer at a public meeting. He was visibly suffering from kidney disease, cardiac problems, and oedematous ankles that pitted on pressure. Despite his ailments, Ferris declared a hunger strike, adding that this time 'it will either be release or death'. On this occasion, Ferris insisted that he would not eat food obtained from anywhere, not even from his wife. He was swiftly released under the Cat and Mouse Act and no attempt was made to re-arrest him and enforce the sentence. ${ }^{130}$

In 1929, both Overbury and Ferris were once again sent to prison after being prosecuted for building a house for themselves without planning permission (which the two individuals did not recognise). Ferris, described in the medical report as 'old for his age, somewhat edentulous and the heat sounds are a little impure', refused food on the basis that he would not obey man-made laws that demanded obedience to the state. The prison Governor Hugh Emerson considered Ferris to be unfit for force-feeding. ${ }^{131}$ Nonetheless, Overbury was repeatedly force-fed despite suffering persistent vomiting. On one occasion, the prison doctor caught Overbury with his fingers lodged down his throat. Closer supervision confirmed that Overbury's vomiting was mostly natural, not self-induced. The medical officer decided against further feedings as the persistent subjection to the procedure was exhausting the ageing Overbury, rendering the exercise futile. ${ }^{132}$

Force-feeding was a procedure with high disciplinary value. While some doctors undoubtedly believed that it helped to save lives, it seems likely that they also recognised the value of feeding technologies in helping to restore prison order and discipline prisoners. If hunger striking was cast as a behavioural problem, then force-feeding appeared to provide a solution. Yet prison doctors encountered a significant number of individuals who were determined to withstand force-feeding due to a firm conviction in 
beliefs, including their own personal innocence, anarchism, breatharianism, and right-wing racism. Although small in number, these prisoners were particularly disruptive and often garnered media interest.

\section{CONCLUSION}

It seems clear that force-feeding did not disappear from prison medical practice following the end of the suffragette and Irish republican campaigns. On the contrary, and despite the controversial death of Thomas Ashe in 1917, prison doctors continued to tackle food refusal with stomach and nasal tubes throughout much of the century. The relatively widespread use of force-feeding remained mostly unnoticed outside of the prison walls. When pursuing hunger strikes alone, most convict prisoners could not amass the support of their fellow prisoners or the general public. Suffragettes and Irish republicans had efficient propagandistic mechanisms that rapidly conveyed news of force-feeding to an interested public. Lacking a supportive network, and relatively isolated from the outside world, convict prisoners tended to pursue unsuccessful hunger strikes unless they possessed enough determination to withstand forcefeeding. Accordingly, force-feeding remained mostly hidden from view; a disciplinary act performed in the private world of the prison deemed so normal in an intrinsically punitive environment that it barely passed comment. Notably, their intervention swiftly eradicated the majority of prisoner hunger strikes, suggesting the punitive nature of force-feeding and prison medicine itself. The records of convict prisoners strongly suggest that force-feeding was not solely used to save lives and preserve health. Although the procedure may well have had some health benefits, it undoubtedly held coercive, punitive value.

\section{Notes}

1. Stafford Smith, Bad Men, p. 214.

2. See discussion in Kew, PCOM7/355, 'Letter Relating to Death of William Edward Burns', 15 March 1918.

3. 'Fatal Hunger Strike: Death in Gaol of Man who Imitated Suffragists at Holloway', Daily Mirror (8 October 1913), p. 4.

4. 'Register of Criminal Prisoners on Hunger Strike'.

5. Vernon, Hunger, pp. 60-80.

6. For recent discussion of prisoner rights and the erosion of staff power, see John R. Hepburn, 'The Erosion of Authority and the Perceived 
Legitimacy of Inmate Social Protest: A Study of Prison Guards', Journal of Criminal Justice, 12:6 (1984), pp. 579-90.

7. 'Register of Criminal Prisoners on Hunger Strike'.

8. Flynn, Pawns in the Game, p. 37

9. Seán McConville, 'The Victorian Prison: England, 1865-1965', in Norval Morris and David J. Rothman (eds), The Oxford History of the Prison: The Practice of Punishment in Western Society (Oxford: Oxford University Press, 1995), pp. 117-50.

10. For the rise of the nineteenth-century prison, see Michael Ignatieff, $A$ Just Measure of Pain: The Penitentiary in the Industrial Revolution, 1750-1850 (London: Macmillan, 1978); Philip Priestley, Victorian Prison Lives: English Prison Biography, 1830-1914 (London: Pimlico, 1999 [1985]).

11. Michel Foucault, Discipline and Punish: The Birth of the Prison (London: Penguin, 1977 [1975]).

12. Ibid., p. 8.

13. Ibid., p. 11.

14. Sim, Medical Power in Prisons, p. 278.

15. Emmeline Pethick-Lawrence, 'Hunger Strikers: The Ordeal of the Imprisoned Suffragettes', Manchester Guardian (8 November 1929), p. 22.

16. Kew, PCOM7/355, 'Letter Relating to Death of William Edward Burns', 15 March 1918.

17. Kew, PCOM7/355, 'Circular from the Prison Commission', undated.

18. Murphy, Political Imprisonment and the Irish, p. 99.

19. Leigh $v$ Gladstone.

20. Kew, CO859/19/7, 'Feeding of Prisoners on Hunger Strike', $1939-40$.

21. Kew, PCOM7/355, 'Forcible Feeding: Methods, Treatment as Hospital Patients', undated.

22. Sim, Medical Power in Prisons, pp. 63-4.

23. Ibid., p. 66. For dual loyalty, see Beverly A. Smith, 'The Irish Prison System-Men in the Middle, 1865-90', Medical History, 26:4 (1982), pp. 371-94.

24. Sim, Medical Power in Prisons, pp. 86-93.

25. Richard R. Prewer, 'The Contribution of Prison Medicine', in Louis Blom-Cooper (ed.), Progress in Penal Reform (Oxford: Clarendon Press, 1974), pp. 116-128 on pp. 127-8.

26. J. C. Spencer, 'Problems in Transition: From Prison to Therapeutic Community', in Paul Halmos (ed.), Sociological Studies in the British Penal Services (Keele: University of Keele, 1965), pp. 13-30.

27. Anthony Babington, The Power to Silence: A History of Punishment in Britain (London: Robert Maxwell, 1968), p. 189. 
28. Hobhouse and Brockway, English Prisons Today; Prison Medical Reform Council, Prison Medical Service: Report of an Enquiry Conducted by Roger Page into the Medical Service of H. M. Prisons (London: Prison Medical Reform Council, 1943).

29. Sim, Medical Power in Prisons, p. 74.

30. Hobhouse and Brockway, English Prisons Today, pp. 267-8 and p. 278.

31. Mary Gordon, Penal Discipline (London: Routledge and Sons, 1922), pp. $\mathrm{x}$-xi.

32. Gordon, Penal Discipline, p. xi.

33. Kew, HOl44/21930, 'Prisons and Prisoners: Forcible Feeding of Prisoners on Hunger Strike-Hunger Strike of Frederick Bowman; Question of Forcible Feeding', 24 March 1944.

34. 'Miss Todd's Hunger Strike Ended', Times (15 February 1972), p. 1.

35. Foucault, Discipline and Punish, p. 16.

36. J. P. Masterton, H. A. F. Dudley and Sheila MacRae, 'Design of Tube Feeds for Surgical Patients', British Medical Journal, ii (October 12 1963), pp. 909-13 on p. 909.

37. William Henry Butter Stoddart, Mind and its Disorders: A Textbook for Students and Practitioners of Medicine (London: H. K. Lewis, 1926), p. 542.

38. Robert Henry Cole, Mental Diseases: A Textbook of Psychiatry for Medical Students and Practitioners (London: University of London Press, 1924), pp. 311-12.

39. Prisoner bed numbers collated from Report of the Commissioners of Prisons and the Directors of Convict Prisons, with Appendices, for 1912-13, Reports of Commissioners, 1914, [Cd. 7092, 7093], xlv.i and Report of the Commissioners of Prisons and Directors of Convict Prisons for the Years 1939-41, Reports of Commissioners, 1945-6, [Cmd. 6820], xiv. 281.

40. 'His Majesty's Prisons (Medical Officers)', House of Commons Debates (23 February 1921), vol. 138 col. 983W. For discussion of the use of force-feeding in prisons with full-time medical staff, see Kew, PCOM7/355, 'Letter to Under-Secretary of State', 14 March 1919.

41. Report of Commissioners of Prisons and Directors of Convict Prisons for the Years 1939-41, pp. 61-2; Sim, Medical Power in Prisons, p. 75.

42. 'Register of Criminal Prisoners on Hunger Strike'.

43. Ibid.

44. Ibid.

45. T. Claye Shaw, 'The Psychology of the Militant Suffragette', Lancet, 181 (17 May 1913), p. 1415; Elaine Showalter, The Female Malady: Women, Madness and English Culture, 1830-1980 (New York: Penguin, 1987 [1985]), pp. 162-4. 
46. Martin J. Weiner, 'The Health of Prisoners and the Two Faces of Benthamism', in Richard Creese, William F. Bynum and Joe Bearn (eds), The Health of Prisoners: Historical Essays (Amsterdam: Rodopi, 1995), pp. 44-58 on p. 46; Ian Miller, 'Constructing Moral Hospitals: Childhood Health in Irish Reformatories and Industrial Schools, c.1851-1890', in Anne Mac Lellan (ed.), Growing Pains: Childhood Illness in Ireland, 1750-1950 (Dublin: Irish Academic Press, 2013), pp. 105-22.

47. Sim, Medical Power in Prisons, pp. 60-2.

48. Ibid., p. 68.

49. Ibid., p. 69.

50. See, for instance, Ruggles-Brise, English Prison System, pp. 198-215.

51. 'Register of Criminal Prisoners on Hunger Strike'.

52. Ibid.

53. Ibid.

54. Ibid.

55. 'Suicide in Prison', Irish Times (2 January 1907), p. 7.

56. 'Prisoners (Suicides)', House of Commons Debates (19 December 1968), vol. 775 cols $443-4$.

57. Philip Priestley, Victorian Prison Lives: English Prison Biography, 1830-1914 (London: Pimlico, 1999 [1985]), pp. 180-4.

58. 'Prisons (Suicide and Insanity)', House of Commons Debates (11 July 1922), vol. 156 cols 1040-1; Weiner, Reconstructing the Criminal, p. 353.

59. Hobhouse and Brockway, English Prisons Today, p. 556; Alison Liebling and Tony Ward, 'Prison Doctors and Prison Suicide Research', in Creese, Bynum and Bearn (eds), Health of Prisoners, pp. 118-33 on pp. 120-1.

60. 'Steinie Morrison Dies in Prison', Irish Times (26 January 1921), p. 4.

61. Priestley, Victorian Prison Lives, p. 172.

62. Ignatieff, A Just Measure of Pain, p.72.

63. Priestley, Victorian Prison Lives, p. 158.

64. 'Register of Criminal Prisoners on Hunger Strike'.

65. Ibid.

66. Miller, Reforming Food in Post-Famine Ireland, pp. 74-8; Miller, 'Food, Medicine and Institutional Life', pp. 207-15.

67. Evelyn Ruggles-Brise, The English Prison System (London: Macmillan and Co., 1921), p. 189. For discussion of prison weight gain and loss, see Ciara Breathnach, 'Medical Officers, Bodies, Gender and Weight Fluctuation in Irish Convict Prisons, 1877-95', Medical History, 58:1 (January 2014), pp. 67-86.

68. Hobhouse and Brockway, English Prisons Today, pp. 126-30. 
69. 'Prison (Diet)', House of Commons Debates (5 April 1944), vol. 398 cols 2008-9; 'Our Prison System', Lancet, 246 (4 August 1945), pp. 145-6; 'H. M. Prisons in the War Years: Report for 1942-4', British Medical Journal, i (8 March 1947), pp. 304-5.

70. Sim, Medical Power in Prisons, p. 94.

71. 'Prisons, Borstals and Detention Centres (Diet Changes)', House of Commons Debates (7 May 1959), vol. 605 cols 68-9.

72. 'Leicester Prison', House of Commons Debates (6 November 1972), vol. 845 cols $67-8$.

73. Fenner Brockway, Inside the Left: Thirty Years of Platform Press Prison and Parliament (London: Allen and Unwin, 1942), p. 91.

74. Ibid., p. 111.

75. '819 Day Hunger Strike Ordeal: M. P.s Told of Ordeal in a British Jail', Daily Mirror (30 January 1974), p. 1.

76. 'Prisoner (Artificial Feeding)', House of Commons Debates (30 January 1974), vol. 868 cols $441-5$.

77. 'Hunger Striker Leaves Army: Medical Grounds', Guardian (14 April 1960), p. 24.

78. John Coveney, Food, Morals and Meaning: The Pleasure and Anxiety of Eating, $2^{\text {nd }}$ edn. (London: Routledge, 2006 [2000]), pp. 65-75.

79. 'Register of Criminal Prisoners on Hunger Strike'.

80. Sim, Medical Power in Prisons, p. 71.

81. Corder Catchpool, Letters of A Prisoner: For Conscience Sake (London: George Allen and Unwin, 1941), p. 48, p. 56, p. 75, p. 77, p. 93.

82. Prison Medical Reform Council, Prison Medical Service, pp. 3-4; Priestley, Victorian Prison Lives, p. 177; Weiner, Reconstructing the Criminal, p. 126.

83. 'Register of Criminal Prisoners on Hunger Strike'.

84. Leon Radzinowicz and Roger Hood, A History of English Criminal Law and its Administration from 1750 (London: Stevens, 1986), pp. 628-9.

85. Hobhouse and Brockway, English Prisons Today, pp. 231-45; Priestley, Victorian Prison Lives, p. 197.

86. 'Register of Criminal Prisoners on Hunger Strike'.

87. Ibid.

88. Ibid.

89. 'Those who have not Escaped', Guardian (19 July 1965), p. 8.

90. 'Wisbey Ends Eleven-Day Hunger Strike', Times (26 July 1965), p. 6.

91. 'Robbers Switched', Daily Express (17 July 1965), p. 1.

92. 'Register of Criminal Prisoners on Hunger Strike'.

93. 'Janie Jones in Gaol Protest', Guardian (16 March 1977), p. 5.

94. 'Hunger Strike in Cardiff Gaol: Family Photographs', Manchester Guardian (23 September 1933), p. 11. 
95. 'Riot Gaol Hunger Strike', Times (15 November 1969), p. 2.

96. Alyson Brown, Inter-war Crime and Penal Policy in England: The Dartmoor Convict Prison Riot, 1932 (Basingstoke: Palgrave Macmillan, 2013).

97. 'Register of Criminal Prisoners on Hunger Strike'.

98. Ibid.

99. 'Protest against Suicide Laws: Man's Letter to Police', Manchester Guardian (13 December 1938), p. 16.

100. 'Hunger-Strike Man Freed', Guardian (3 February 1971), p. 1.

101. Ibid, p. 1.

102. 'Alfred George Hinds (Forcible Feeding)', House of Commons Debates (4 July 1957), vol. 572 col. 1291.

103. 'The Hinds Case: Thirty M. P.s Call for Inquiry', Manchester Guardian (6 July 1957), p. 1.

104. 'The Black Man's Burden', Daily Mirror (19 May 1976), p. 3.

105. 'That Notice Stays Up, Says Freed Race Rebel', Daily Express (22 June 1976), p. 2.

106. 'Move in Race Case', Guardian (26 May 1976), p. 1.

107. 'It's Back to Jail for a Window Breaker', Daily Express (12 November 1969), p. 7.

108. 'Dr Moore not to be Forcibly-Fed: Consultant's Promise', Guardian (15 May 1962), p. 3.

109. 'When Dr Babs Will be Given Food', Daily Mirror (15 May 1962), p. 2.

110. Joseph F. King, 'The Foundations of Police Unionism in the United Kingdom: The Case of Inspector John Syme', Law Enforcement Executive Forum (March 2011), pp. 173-87.

111. V. L. Allen, 'The National Union of Police and Prison Officers', Economic History Review, 11:1 (August 1958), pp. 133-43.

112. Kew, MEPO3/838, 'Report on Case of John Syme', 28 May 1920.

113. Kew, MEPO3.838, 'Letter to General Sir Nevil Macready from Sir John Rowlandson', 14 June 1919.

114. Kew, MEP3/838, 'Letter from John Syme to Gernal Horwood, Police Commissioner', 26 April 1920.

115. Kew, MEPO3/838, 'Letter from George Wood', 19 May 1920.

116. 'Report on Case of John Syme'.

117. 'Wireless Broadcasting', House of Commons Debates (4 August 1922), vol. 157 cols $1951-75$.

118. Kew, MEPO2/10202, 'Hunger Strikes by Syme; Releases from Prison under 'Cat and Mouse' Act: Prisoners (Temporary Discharge for Ill Health) Act 1913', August 1923.

119. Kew, MEPO3/1844, 'John Syme: Transfer to Criminal Lunatic Asylum and Epsom Mental Hospital', 25 May 1925. 
120. 'Ex-Inspector Syme (Widow)', House of Commons Debates (11 March 1948), vol. 448 cols 1552-6.

121. 'Hunger Strike in Gaol', Guardian (22 July 1969), p. 1.

122. 'Visiting Ban on Hunger Striker', Guardian (29 March 1975), p. 5.

123. The Times (19 December 1972), p. 2.

124. 'Register of Criminal Prisoners on Hunger Strike'.

125. Charlotte Alston, Tolstoy and his Disciples: The History of an International Movement (London and New York: I. B. Tauris, 2014), p. 224.

126. Kew, HOl44/20983, 'Memorandum', 18 December 1915.

127. Kew, HOl44/20983, 'Transcript of Telephone Conversation with the Governor of Leeds Prison', 18 December 1915.

128. Kew, HOl44/20983, 'Memorandum from Lord Courtney', 28 December 1915.

129. Kew, HO 144/20983, 'Letter to Brigadier General Childs', 30 October 1916.

130. Kew, HO 144/20983, 'Letter from Leeds Prison to Home Office', 9 June 1925.

131. Kew, HO 144/20983, 'Letter from Hugh Emerson to Home Office', 5 July 1930.

132. Kew, HO 144/20983, 'Letter from Hugh Emerson to Home Office', 14 July 1930.

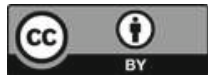

This chapter is distributed under the terms of the Creative Commons Attribution 4.0 International License (http://creativecommons.org/ licenses/by/4.0/), which permits use, duplication, adaptation, distribution and reproduction in any medium or format, as long as you give appropriate credit to the original author(s) and the source, provide a link to the Creative Commons license and indicate if changes were made.

The images or other third party material in this chapter are included in the work's Creative Commons license, unless indicated otherwise in the credit line; if such material is not included in the work's Creative Commons license and the respective action is not permitted by statutory regulation, users will need to obtain permission from the license holder to duplicate, adapt or reproduce the material. 


\section{'An Experience Much Worse Than Rape': The End of Force-Feeding?}

At the twenty-ninth World Medical Assembly, held in Tokyo in October 1975, the World Medical Association formally declared that physicians should maintain the utmost respect for human life. First and foremost, the Declaration was concerned with stopping doctors participating in torture, defined as 'the deliberate, systematic or wanton infliction of mental suffering by one or more persons acting alone or on the orders of any authority to force another person to yield information, to make a confession, or for any other reason.' The Declaration insisted that physicians should never partake in cruel, inhuman, or degrading acts, particularly during civil strife or armed conflict. The Declaration also maintained that the right of patients (or victims) to be able to refuse medical treatment should never be overruled. Physicians should always act with clinical independence from state bodies. The Declaration was written in response to concerns about doctors helping to torture political opponents. In the Soviet Union, doctors had allegedly misdiagnosed politicised prisoners as insane to authorise their asylum incarceration. In Argentina, Brazil, Chile, and Uruguay, medical personnel had reportedly helped security agencies to torture by resuscitating prisoners who were close to death and issued false death certificates. From 1972, Amnesty International brought these issues to public attention and appealed to end medical participation in torture. ${ }^{1}$ Notably, article six of the Declaration stated:

Where a prisoner refuses nourishment and is considered by the physician as capable of forming an unimpaired and rational judgment concerning the

(C) The Author(s) 2016 
consequences of such a voluntary refusal of nourishment, he or she shall not be fed artificially. The decision as to the capacity of the prisoner to form such a judgment should be confirmed by at least one other independent physician. The consequences of the refusal of nourishment shall be explained by the physician to the prisoner. $^{2}$

This statement provided the first formal declaration of medical ethical standards relating to the medical management of hunger strikers, particularly those likely to be fed against their will. But why was it only at this particular historical juncture that the medical profession formally denounced force-feeding as unacceptable? Who spoke out against force-feeding, and why? And did a particular socio-cultural climate exist that encouraged success? The chapter suggests that in the 1970s, Britain once again found itself centre-stage in ethical debates about the management of hunger strikers. In the opening decade of the Northern Irish Troubles (c.196998), deep controversies came to surround the prison treatment of Irish republicans. The public visibility of republican hunger strikes re-ignited debate on force-feeding. Although English convict prisoners had been (somewhat covertly) force-fed for some decades, force-fed PIRA prisoners garnered considerable attention. During the Troubles, the British and Northern Irish governments used imprisonment extensively and found themselves accused of supporting dubious institutional treatment. As in the past, questions were raised about whether force-feeding amounted to torture, if the procedure was safe and if doctors performing the procedure were acting autonomously from the state. Yet the socio-cultural climate in which these questions resurfaced had radically changed. Force-feeding now took place against an international backdrop of concern over human rights, breaches of civil liberties, and the excesses of institutional medical power more generally. This milieu was particularly amenable to successful outcries against force-feeding.

The nature of PIRA violence, which included the bombing of innocent civilians across the British Isles, presented an ethical quandary for the public. As John M. Regan suggests, the implications of defeating republican subversion confronted British citizens with a dilemma about the nature of political and institutional responses to the republican threat. Few people looked favourably upon political violence. Yet, for many, forcefeeding seemed deplorable. The use of excessive physical force to tackle PIRA hunger striking challenged basic tenets of British liberal culture. A majority of people remained unsympathetic to PIRA and its relentless 
slaughtering of innocent civilians. Yet torturing and degrading prisoners seemed to contradict deeply entrenched ideas on what it means to live in the modern, civilised west; it produced a strong emotional response. ${ }^{3}$ Even a state under threat needed to preserve its dignity. Moreover, forcefeeding was now being performed in a period of heightened concern over marginalised groups, including prisoners and Northern Irish Catholics. It had also resurfaced at a time when the nature of medical paternalism itself (particularly in institutions) was being critiqued in academic and popular culture, as exemplified by Ken Kesey's novel and film One Flew over the Cuckoo's Nest and Michael Foucault's Discipline and Punish. This chapter examines the reasons why force-feeding became so prominent in the public eye in the mid-1970s. It suggests that issues such as the force-feeding of female prisoners added affective dimensions to public discussion of hunger strike management. It also maintains that the mid-1970s presented a suitable setting for successful condemnation of perceived lapses in human rights and medical ethics. The basic questions surrounding force-feeding differed little from earlier periods. Yet pain, suffering, and torture was now being imposed in a period when active opposition could form, find a voice and encourage policy change and where patient autonomy was more valued. Understanding why force-feeding policies changed in the 1970s allows us to understand why the re-emergence of force-feeding at Guantánamo seems all the more problematic in the twenty-first century.

\section{The Troubles and Political Imprisonment}

Since its inception in 1921, the Northern Irish state had been overwhelmingly dominated by Unionist (primarily Protestant) politicians who prioritised preserving the integrity of the state against a Catholic minority seen as staunchly republican and eager to re-unite with the south of Ireland. Unionists firmly believed that it was in their socio-economic, political, and cultural interests to remain within the UK, a conviction fortified as the southern Irish state became increasingly Catholic-orientated throughout the century. For Unionists, the government of a united Ireland was unlikely to be too concerned with the interests of a northern-based Protestant minority. To safeguard the state against re-unification, Catholics were mostly excluded from Northern Irish politics and senior civil service positions. Between the 1920s and 1960s, discrimination against Catholics ran so deep that many lacked equal levels of access to housing, education, and health care. ${ }^{5}$ Throughout the 1960s, Prime Minister Terence O’Neill tried 
to encourage greater Catholic participation through fairer participation in elections, equitability in the allocation of state resources and security against arbitrary arrest. Yet O'Neill failed to deliver on most of his promises (partly because of opposition among hard-line unionists), exacerbating dissatisfaction among Catholic communities. ${ }^{6}$

Inequalities and irreconcilable viewpoints encouraged political dissidence. In the late 1960s, hard-line Unionists felt endangered by an emerging, Catholic-focused, Northern Irish civil rights campaign. For them, the integrity of the state was under threat. In response, fundamentalist preacher, Ian Paisley, formed the Ulster Constitution Defence Committee and established a paramilitary-style wing called the Ulster Protestant Volunteers. ${ }^{7}$ Tensions increased further when a civil rights group in Derry was violently subdued by the Royal Ulster Constabulary (RUC) in October 1968. In 1969, escalating violence led the British government to deploy troops in Northern Ireland. While the army initially protected Catholic communities from loyalist violence, its role swiftly changed to tackling PIRA. For many Catholics, this represented British collusion with unionism. ${ }^{8}$ PIRA formed in 1969 as a more militant offshoot of the IRA. It saw violence as the most appropriate means of attaining full national independence. ${ }^{9}$ Militant republicanism increasingly appealed to Catholic communities who felt alienated from both the Unionist-dominated RUC and the British forces. PIRA fed upon the dissatisfaction of minority communities who deeply distrusted Northern Ireland's political, policing, and military infrastructure. During the 1970s, republican and loyalist violence increased. Both groups retaliated against each other for murders and bombings, perpetuating a cycle of violence. ${ }^{10}$

As had been the case in the War of Independence some fifty years earlier, prisons once again became a locus of socio-political contention. Hunger strikes began to attract public attention in 1971 when Prime Minister, William Faulkner, implemented a policy of internment without trial. On 9 August 1971, he launched Operation Demetrius. In an initial swoop, thousands of military troops and police made 340 arrests. Problematically, a large number of people with no discernible PIRA connections were arrested, interrogated, and, in many instances, subjected to degrading treatment. The RUC Special Branch which collated information on suspects had relied heavily on out-of-date information on IRA membership collected during the unsuccessful Border Campaign of 195662. ${ }^{11}$ Violence broke out in many areas of Belfast. Nonetheless, internment remained in place for four years, despite a growing realisation that 
the policy was in fact strengthening the appeal of republicanism. Frequent, and often unnecessary, house searches in Catholic areas of Belfast, such as Falls Road, provoked further ire. ${ }^{12}$ Indeed, the government seemed intent on repressing the republican threat and less inclined to tackle unionist paramilitary violence. ${ }^{13}$ Such difficulties encouraged human rights groups to strongly condemn internment nationally and internationally. ${ }^{14}$

To accommodate a rapid growth in prisoner numbers, the government opened the Long Kesh/Maze Internment Camp on the outskirts of Lisburn as a temporary necessity in August 1971. Internees were gradually transferred to the camp from Crumlin Road Prison, Belfast, and the HMS Maidstone moored in Belfast Lough. ${ }^{15}$ Some hunger strikes attracted considerable attention. In May 1972, founding PIRA member, Billy McKee, went on hunger strike. ${ }^{16}$ Billy sought to secure special category status. He was soon joined by a number of other prisoners. On the twenty-fourth day of their protest, the prisoners were reportedly too dazed and weak to leave their beds. ${ }^{17}$ The protest ended after thirty-five days when Northern Irish Secretary of State, William Whitelaw, granted concessions. ${ }^{18}$ His decision bore important implications for subsequent hunger strikes. Politicised prisoners were now allowed to wear civilian clothing, receive more visits and food parcels, and access improved educational provisions. ${ }^{19}$ This was an important step. Prior to 1972, the Northern Irish government and prison service had typically downplayed the politicised nature of violence in Ulster. As such, political prisoner status had not been formally recognised..$^{20}$ Nonetheless, Whitelaw later regretted his decision to introduce political prisoner status due to the complexities which it was to pose within the prison system. ${ }^{21}$

\section{The Force-Feeding of Dolours and Marion Price}

In 1972, PIRA commenced a campaign on the British mainland that involved bombing sites such as the Old Bailey and Whitehall. Those arrested in England tended to serve their sentences there. Some went on hunger strike. As the previous chapter demonstrated, force-feeding was common in twentieth-century English prisons. While hunger striking, PIRA members imprisoned in England found themselves exposed to being fed against their will. Prison doctors attempted to restore prison order by once again resorting to the stomach tube. For those living in Britain (distant from the intensity of the Troubles), PIRA's mainland campaign often appeared meaningless and ill-targeted (as later exemplified by 
the injuring of forty-one innocent children in an explosion at the Tower of London in July 1974). ${ }^{22}$ But, to many, force-feeding seemed equally excessive. It encouraged public reflection on broader issues relating to the exertion of state and medical power and an apparent erosion of basic liberal principles and human dignity. These concerns surfaced even within a national context that mostly abhorred PIRA violence.

In 1973, eight PIRA members were convicted and imprisoned for detonating car bombs in London. One civilian had died. Almost 200 others had been injured. The so-called 'Winchester Eight' consisted of sisters Dolours and Marian Price, Gerald Kelly, Hugh Feeney, Robert Walsh, Martin Brady, William Armstrong, and Paul Holmes. All hailed from Belfast and were aged between nineteen and twenty-four. Upon being convicted, they were dispersed to different prisons and treated as convict, rather than special category, prisoners. In November, the Winchester Eight started a highly publicised hunger strike. Four of the prisoners capitulated. Yet the Price sisters, Gerald Kelly, and Hugh Feeney persevered with their fasts until mid-1974. ${ }^{23}$ These prisoners were force-fed for over 200 days. Their stated goal was to secure a transfer to a Northern Irish prison. In a peculiar twist of fate, prison doctors force-fed the Price sisters in the very same room that Terence MacSwiney had passed away in at Brixton Prison some fifty years earlier, although this potentially provocative detail was not publicly disclosed. ${ }^{24}$

As ever, force-feeding sparked debate. But, on this occasion, compassion felt towards the force-fed ultimately translated into firmer regulation of prison medical behaviour. Why had this not occurred earlier? After all, evocative images of female prisoners being fed with stomach tubes had shocked the Edwardian public but ultimately failed to persuade the government or prison doctors to stop feeding prisoners against their will. In revolutionary-period Ireland, Thomas Ashe had died shortly after being force-fed. Yet this had failed to encourage the medical profession to outline a definite stance on force-feeding. The procedure had been performed regularly in twentieth-century English prisons but garnered only sporadic public interest. What factors, then, encouraged the profession to finally deem force-feeding to be a harsh disciplinary mechanism and an overexertion of medical duty?

The high levels of publicity awarded to Dolours and Marian Price played an important role. Republican force-feedings were far more visible than convict feedings. However, the fact that two female prisoners were being fed perhaps provided the most important catalyst. The young age of 
the sisters (aged nineteen and twenty-three respectively) further strengthened this affective aspect of the situation. Given that the public generally associated Irish republicanism with robust masculinity, hunger strikes pursued by two young sisters presented something of a curiosity, a transgression of behaviour typically expected from Irish women. Sikita Bannerjee suggests that militant women occupied an ambiguous space within PIRA as its male members characteristically cast the ideal Irish women as passive and chaste. ${ }^{25}$ Indeed, the independent Irish state itself had been modelled upon the concept of the chaste, innocent, and passive female as moral guardian of the nation. ${ }^{26}$ By partaking in brute violence and expressing an unyielding determination to fast until death, the sisters openly disrupted and challenged gendered expectations. Images of two young women willing to mutilate their own bodies and sacrifice their physical integrity for a cause that associated itself with heroic masculinity disconcerted the public. Notably, the force-feedings of the two men-Kelly and Feeney-received relatively scant media attention, particularly in Britain. Republican men, after all, were expected to be able to endure procedures such as forcefeeding, their bodies seemed less fragile and vulnerable. In contrast, the Price sisters found themselves constantly in the media spotlight, if only to be cast as an aberration on gendered norms.

How did journalists make sense of the Price sisters' turn to violence? And in what ways did perceptions of female violence feed into public discourse on their feedings? Notably, the sisters were commonly referred to as 'girls', a narrative act that underscored a sense that they had prematurely lost their innocence. In Britain, journalists portrayed the sisters as monstrous and violent creatures, as women whose sense of social norms had somehow been corrupted and perverted. Traditionally, explanations for violent - particularly murderous - female acts had been sought in biology. In the early twentieth century, doctors and legal experts mostly agreed that certain stages of the female life cycle-particularly adolescence-placed women at high risk of mental instability that could manifest in crime and violence. ${ }^{27}$ Such ideas formed the basis of expert opinion on crimes such as infanticide. ${ }^{28}$ However in the post-war period, criminologists sought alternative explanations in social environments, family disorganisation, and individual psychopathology. ${ }^{29}$ Northern Ireland was readily portrayed as a hotbed of social disorganisation, a pathological location which bred abnormality and violent tendencies.

Explanations for the Price sisters' unfeminine behaviour could easily be identified in the Northern Irish social environment, an idea that 
informed the manner by which the Daily Express framed an interview with Albert Price, father of the two sisters, in 1974. Journalist Paul Dacre, in his discussion of the 'two warped minds' of the sisters, interviewed their father in an effort to comprehend 'the sick climate from which they [the sisters] sprang'. Seeking explanation for the Prices' aberrant transgression of feminine norms, Dacre depicted a pathologised social climate in Belfast (specifically in the Catholic-dominated Falls Road area) tarnished by a normalisation of violence. Dacre portrayed Albert as oblivious to the extent to which violence had seeped into the Price household. $\mathrm{He}$ observed a wooden replica of a Thompson machine gun made by a Long Kesh internee hanging above the fireplace over a picture of his two daughters, obvious tropes of Irish republicanism. Dacre interspersed the father's comments on the sisters once being 'lovely young girls' with descriptions of a living room replete with an array of books on the Easter Rising and photographs of uniformed PIRA youths attending parades. Dacre presented Albert as oblivious to the psychological damage which he had wrought upon his daughters by sustaining a militaristic domestic environment in his living room. Notably, the Daily Express published this piece alongside an interview with a victim of the Old Bailey bombing who remained traumatised by injuries to his right eye caused by flying glass. ${ }^{30}$ While the Daily Express did not make the connection explicit, its two stories were inextricably interrelated. The implications were clear. Dolours and Marion had been raised in a household where violence seemed normal; in a setting where the father figure failed to envisage how the military-esque environment of his living room might have made a lasting psychological imprint on his two daughters. It was within this pathological environment, Dacre implied, that the seeds of the sisters' deviant behaviour had been planted with catastrophic results for innocent by-standers. ${ }^{31}$

In Ireland, the Kerryman also reinforced the significance of environmental factors in 'perverting' the Price sisters' minds by stating:

Many people have an interest in the future of the Price sisters. The sentences they received were savage. The offences of which they were found guilty were very serious and few will condone them. Nevertheless, they are very young and will be seen by thinking people as very much victims of their environment and background. Their capacity for subversion ceased when they were imprisoned. Now they are two young people far from their home and friends, at the mercy of a brutal force-feeding system which is an outrage against nature. ${ }^{32}$ 
As in the Daily Express' account, the idea that two young 'girls' might have chosen to engage with militant republicanism seemed somewhat alien. Whereas republican men who bombed cities and innocent civilians could, in a sense, be cast as conforming to masculine behaviour at times of conflict, contemporaries sought alternative explanations for female militancy. This added a sense of innocence to the Price sisters which, in turn, strengthened the emotional impact of reports of their encounters with their prison doctors. The imposition of force-feeding on two young 'girls' who seemed scarcely responsible for their deviant psychological conditions caused discontent; their willingness to endure force-feeding and to die, if necessary, added a further monstrous dimension to perceptions of what these 'girls' had been transformed into. The framing of the sisters as passive victims of social disorganisation encouraged even those outraged by PIRA atrocities to empathise. Moreover, the refusal of the government to grant the hunger strikers' request to be imprisoned in their own country, and its stubborn determination to impose physical violence, raised questions about the appropriateness of responding to physical violence with further violence.

Like earlier accounts of force-feeding, first-hand reports confirmed the perennial prisoner complaint that force-feeding was painful and degrading; more resembling torture than therapeutic intervention. In turn, this raised questions about the function of inflicted pain in a modern liberal society and its purpose in protecting Britain and Northern Ireland from 'terrorism', particularly given that the sisters' requests seemed relatively reasonable. Published accounts of the Prices' experiences encouraged readers to connect emotionally with their plight, producing mixed feelings attitudes towards individuals who had themselves caused pain and trauma. In January 1974, Claire Price (sister of Dolours and Marian) described her sisters' condition after seventy-eight days of hunger striking (published in the Guardian) as follows: 'The two would now be unrecognisable to anyone who had seen them in the Winchester trial ... their faces have gone a waxy colour and they have sores around their mouths. They are both much thinner and they are complaining that they cannot sleep.' ${ }^{33}$ This representation of a mixture of self-mutilation and enforced brutality by prison medical staff proved emotive, reinforcing a sense that the Price sisters were becoming physically and psychologically unrecognisable from the young women who they should have grown into. In the same month, the Kerryman published part of a letter sent by Dolours to her mother which read: 
I was scared stiff when I saw the tube and the wooden clamp for my mouth. The worst bit was when I couldn't get my breath as the tube was going down. I really panicked then as I thought I was suffocating. It takes only a few minutes but it seems like an eternity.

Marian Price added that 'I am not ashamed to say it is a very horrific and terrifying experience. I've had it three times now, but it doesn't get any easier.' ${ }^{34}$ In February, republican $\mathrm{MP}$ and civil rights campaigner, Bernadette Devlin McAliskey, publicly stated that 'until the force-feeding is over, they [the sisters] cannot think of anything else and spend the morning mentally preparing themselves. The mental agony of waiting by now outweighs the physical pain of feeding.' 35

The Price sisters' personal accounts confirmed the sense of intimidation and physical discomfort prominent in other historical depictions of force-feeding. In a subsequent interview, Marian described the procedure as follows:

Four male prison officers tie you into the chair so tightly with sheets you can't struggle. You clench your teeth to try to keep your mouth closed but they push a metal spring device around your jaw to prise it open. They force a wooden clamp with a hole in the middle into your mouth. Then, they insert a big rubber tube down that. They hold your head back. You can't move. They throw whatever they like into the food mixer; orange juice, soup or cartons of cream if they want to beef up the calories. They take jugs of this gruel from the food mixer and pour it into a funnel attached to the tube. The force-feeding takes fifteen minutes but it feels like forever. You're in control of nothing. You're terrified the food will go down the wrong way and you won't be able to let them know because you can't speak or move. You're frightened you'll choke to death. ${ }^{36}$

A particularly emotive description of being force-fed was published in the Spectator, highlighting how the ethical implications surrounding the procedure generated debate outside of sensationalistic tabloid journalism. In February, the Spectator equated force-feeding with sexual assault, mirroring (but more explicitly stipulating) implications made by the suffragettes on the physical and emotional intrusiveness of force-feeding. The Spectator asserted:

How many of us would want to live after being forcibly-fed? This is an experience much worse than rape. The emotional assault on the person can 
be permanently damaging. The calculated administration of an experience such as forcible-feeding to someone who just cannot, or will not, eat is, to me, infernal, whether the subject is a recalcitrant old lag in prison or a young woman held without trial. To restrain, even to punish, is one thing; to torture something very different. With the possible exception of the treatment of the mentally ill who may be violent and, indeed, act violently against themselves, it would seem that those who give instructions for forciblefeeding and those who obey should be judged like the torturers of the concentration camps, the rapists of certain Far East campaigns, the perverters of children. ${ }^{37}$

The Spectator's message was clear. The force-feeding of two young 'girls' amounted to torture, assault and a gross perversion of institutional power, reminiscent of the worst excesses of those countries which had threatened liberal society in the past. Even despite the violence of PIRA bombings, public representations of the Price sisters struggled to move beyond the sense that innocence had been lost-and was continuing to be lost-due to the excessive actions of prison doctors. In contemporary discourse, adolescent girlhood was ideally marked by a sense of immature and malleable identity, as a symbol of desirability, rather than independence, maturity, ${ }^{38}$ The Price sisters had clearly transgressed these norms, but was it really necessary to further contribute to their descent into physical and mental perversion by effectively raping them rather than providing rehabilitation? Certainly, the parallels drawn with rape would have been less effective if Kelly and Feeney (never referred to as boys) had been the subject of such speculation, particularly given the unspoken nature of the topic of male rape. The Spectator added to a broader discussion of the bodies and minds of the Price sisters having been perpetually battered and distorted by the domestic environment in which they grew up; the violent society in which they had been reared; and, now, the apparent torture to which they were being subjected to while imprisoned.

In Belfast, a pamphlet published in Catholic enclave Anderstown announced that force-feeding was a 'Nazi-style torture' ${ }^{39}$ It also provided the following account:

At last it has happened, today, on the nineteenth day of hunger strike, I was forcibly-fed. Unpleasant in the extreme. Actually what led up to the force-feeding was that on Saturday, after my bath, I clocked out [fainted] and my blood pressure dropped a bit ... so forcible-feeding was the next step .... I really paniced [sic] as I thought I was suffocating. It only takes 
a few minutes but it feels like an eternity. To crown matters I was violently sick afterwards and brought everything up. I feel a wee bit better now but I am dreading going through it all again tomorrow. It's only to be expected that after nineteen days without food, my stomach would reject the 'feed' ${ }^{40}$

A special edition of IRA newspaper An Plobacht paid more attention to the male prisoners but similarly depicted force-feeding as torture. It printed a statement made by one prisoner that the mental agony of waiting to be force-fed is getting to the stage when it now outweighs the physical discomfort of having to go through with it. ${ }^{41}$ An Plobacht detailed the harsh use of surgical instruments on Gerard Kelly's gums and jaw during force-feeding, causing internal bleeding. According to the newspaper, Gerard's teeth had been broken as the doctors forced his mouth open with a lever. In relation to Hugh Feeney, An Plobacht recorded that 'the tube is pushed hastily into his stomach, doubling as it goes, causing him severe pain', and that the water poured into Hugh's mouth had a strong saline content which was causing his lips and gums to crack and bleed. ${ }^{42} A n$ Plobacht called upon its readers to 'stop the slow and agonising execution of these young Irish citizens' by writing to Prime Minister Edward Heath demanding that force-feeding be stopped. ${ }^{43}$

Evidently, discussion of the Price sisters' prison treatment reinvigorated claims that force-feeding was torturous, traumatic, and excessive. As in other historical contexts, the key issue was not so much whether prisoners should be kept alive but whether force-feeding formed part of a broader programme of discipline and punishment used solely to stop political protest. Nonetheless, far broader questions were at stake about the nature of modern liberal society and how the state chose to manage its political dissidents. Between 1973 and 1974, the enactment of physical and emotional discipline on two young 'girls' with discernible political beliefs caused concern. Equally importantly, femininity was considered in discussion of force-feeding for the first time since the 1910s, helping to attract a level of public attention to the subject not seen since the Edwardian period.

\section{Human Rights and Prisoner Welfare}

While the harrowing depictions of force-feeding published regularly in the national press provoked an emotional public response, the eradication of the practice from English prisons was contingent upon a particular 
socio-cultural milieu in which opposition to force-feeding could finally translate into policy change. Earlier, suffragettes and conscientious objectors had been unable to persuade policy makers and medical communities to formally condemn the procedure. In Ireland, Thomas Ashe's death had discouraged doctors from force-feeding. However the controversy surrounding this fatality rested primarily in Ashe's prominent republican status in the Irish public consciousness. In Ireland, force-feeding had not been abandoned solely for ethical reasons. In contrast, the Price sisters were force-fed against the backdrop of a late-century socio-cultural milieu with heightened sensibilities towards accusations of torture and institutional abuses.

A robust human rights movement now existed which swiftly condemned allegations of torture and breaches of human rights. Since the Edwardian period, critics had equated force-feeding with torture and suffering. Yet, an international framework designed to preserve individual liberty was not then in place, although a general feeling certainly existed that force-feeding seemed excessive and unjust. As Joanna Bourke maintains, since the eighteenth century, ethical thought has been inflected by states of feeling. In a progressive, caring society, respect for the bodily integrity of others (as demonstrated by the declining use of capital punishment and torture during interrogations) has encouraged empathy for those in pain. ${ }^{44}$ In the 1940 s, the extremities of Nazi violence had ignited a feeling that universal human rights needed to be enforced, resulting in the Declaration of Human Rights of December $1948 .{ }^{45}$ During the Prices' hunger strikes, newspapers and republican propaganda fuelled a sense of perpetrated torture in the public imagination, encouraging compassionate attitudes to evolve rooted in humanitarian considerations. If force-feeding did amount to torture, then it could be readily portrayed as a breach of human rights. The emotional aspects of 'torture' profoundly clashed with the rational political logic of refusing to concede to prisoner demands to protect national security. ${ }^{46}$

In the 1970s, human rights activists were deeply concerned about torture. Presumptions that the Northern Irish Troubles stemmed from civil rights issues attracted further attention to the plight of imprisoned republicans. ${ }^{47}$ Moreover, the Troubles coincided with a burgeoning international apprehension about the lack of rights possessed by prisoners specifically. Internationally, riots took place in prisons including Parkhurst on the Isle of Wight and Folsom, California. Both proved newsworthy. In summer 1972, protests erupted in thirty-eight British prisons relating to 
institutional conditions. ${ }^{48}$ A legitimate challenge was being posed to the authority of western penal systems that called into question the supposedly rehabilitative, rather than punitive, nature of prisons. Some critics went so far as to campaign for the entire abolition of the prison network, seeing it as just as outdated as the former workhouse system. ${ }^{49}$ Prison protests were typically initiated by groups who saw themselves as deprived of civil liberties outside of the prison (such as black communities in America), demonstrating the interconnections between struggles inside and outside of the institution. Moreover, protesting prisoners increasingly fashioned themselves as politically focused and demanded to be treated as such. ${ }^{50}$ These factors converged in public discussion of the Price sisters' forcefeedings, ensuring that the matter garnered attention as a potential human and prisoner rights infringement. Accordingly, force-fed prisoners found support from an array of human rights and civil liberties groups who saw prison welfare as integral to their activities. ${ }^{51}$

Decisively establishing force-feeding as a contravention of human rights was a formidable task. In December 1973, solicitor, Bernard Simons, attempted to apply for an injunction and a Declaration of Right to prevent the Price sisters from being fed. According to Simons, forcefeeding constituted 'an assault on the person'. Simons maintained that the government had no right to feed prisoners against their will, an argument that contradicted the traditional stance on prison doctors having an ethical duty to keep prisoners alive. ${ }^{52}$ The application was dismissed. ${ }^{53}$ Public opinion remained divided. Ted Ward, organiser of the Preservation of the Rights of Prisoners movement, and Martin Wright, director of the Howard League for Penal Reform, believed that the government was correct to authorise force-feeding. In contrast, the National Council for Civil Liberties maintained that force-feeding contravened Article 3 of the European Convention of Human Rights which prohibited inhuman and degrading treatment. The Council viewed force-feeding as a brutal and gross violation of personal freedom. ${ }^{54}$

The portrayal of force-feeding as torturous provided a useful trope for civil, human, and prisoner rights groups who sought to bring the matter to the forefront of public attention throughout 1974, most successfully in Ireland and Northern Ireland. In January, the Irish Civil Rights Association also claimed that force-feeding contravened the European Convention of Human Rights which prohibited the degrading treatment of persons held in custody by the State. ${ }^{55}$ The Dublin branch of the Association for Legal Justice condemned force-feeding as an assault upon human dignity and a 
deprivation of prisoner rights, adding that 'torture of a human being in any circumstances is appalling, but practised by government agencies on a defenceless prisoner is abominable. ${ }^{56}$ A number of well-publicised protests were organised by the Irish Civil Rights Association. In December 1973, an effigy of British Minister for Home Affairs, Robert Carr, was burned with two tricolour-draped coffins outside the passport office in Merrion Square, Dublin. ${ }^{57}$ In the following month, 170 members of the Association marched to the residence of British ambassador, Arthur Galsworthy, in Sandyford, Dublin, demanding the repatriation of Irish political prisoners. ${ }^{58}$

It is worth briefly noting that the treatment of the Price sisters failed to attract consolidated support from the second-wave feminist movement. In 1974, British feminist magazine, Spare Rib, attempted to cast the feedings as a potential women's rights issue. Familiar images of male doctors subjugating defenceless female prisoners had once again surfaced. Yet their efforts raised contention. Many feminists chose to portray themselves as peaceful and compassionate, often to highlight the important contribution which women could potentially make in a male-driven world seemingly driven by conflict and violence. The magazine's coverage of the Price sisters met a mixed response. One reader suggested that Spare Rib had taken up the cause solely because it was female prisoners who were being fed, and suggested that the feminist movement could not support all women, particularly those who 'killed indiscriminately with bombs and guns just like the misguided men'. A further reader accused the magazine of 'soiling the memory' of the suffragettes by drawing parallels between PIRA and suffragette militancy. ${ }^{59}$ The gendered dimensions of the Price sisters' feedings certainly sparked public discussion, But the extremities of PIRA violence ultimately mitigated against full support from the feminist movement, a somewhat ironic scenario given that the modern prison hunger strike had first emerged from that cause.

Evidently, force-feeding became entangled within a complexity of broader debates on prisoner welfare, the rights of minority communities, and the precarious nature of the modern prison system itself, construed by its critics as a barrier to human dignity. The Declaration of Human Rights defines torture as the wilful infliction of physical or psychological violence on individuals often on the authority of the state. Torture can be punitive, dehumanising, or deterrent. ${ }^{60}$ However defining what precisely constitutes torture-particularly in contexts of conflict-can be problematic. While some displays of violence and intimidation quite clearly amount to torture, 
others (such as force-feeding) are contestable. ${ }^{61}$ In the 1970s, the infliction of pain in state-managed institutions added further complications. Pain had served little function in the judicial system since the eighteenth century when the public infliction of harm upon the bodies of criminals had helped to inscribe authority, encourage repentance, and, in theory, deter others from committing crime or sin. Yet pain, punishment, and suffering mostly lost their religious moorings during that century. By the twentieth century, punishment (and imprisonment) was generally viewed as an opportunity for criminals to repay their 'debt' to society. In historian Lynn Hunt's words, no payment could be forthcoming from a mutilated body. ${ }^{62}$ In the 1970s, rehabilitation and re-entry into society were, ostensibly, the chief aims of imprisonment, ensuring that mutilation and violence seemed intolerable. ${ }^{63}$ Force-feeding sat particularly uneasily within late twentiethcentury discourses on pain.

What does seem clear is that the manner by which force-feeding was performed - with its loss of human dignity and degradation-was rendered meaningful in light of a socio-cultural context that privileged the sanctity of human rights. Adding weight to accusations of torture, in February 1974, Albert Price reported to the press that his two daughters were being tied to their chairs during their feedings, an act easily portrayed as degrading and intimidating. ${ }^{64}$ The psychological effects of force-feeding were also not lost on contemporary critics, as evident in the affective depictions of the procedure that played upon the aftermath of rape. During an Irish Civil Rights Association demonstration, practicing psychiatrist, Brian Lavery, asserted that the psychological effects of being force-fed were similar to multiple rape, once again highlighting the importance of sexual analogies in framing contemporary debates. ${ }^{65}$ The physically and emotionally traumatic nature of force-feeding had always caused unease. Yet organised movements now existed that could actively campaign against such problems. Whereas the suffragettes had relied primarily upon their own propaganda and public support among prominent individuals where they could find it, the Price sisters were supported by a mobilised network of human and civil rights activists who mostly had no connection whatsoever with PIRA.

\section{Medical Ethics and Force-Feeding}

The construction of force-feeding as a human rights concern bore important implications for those performing the procedure: the prison doctors. The development of the human rights movement dovetailed with rising 
pressure placed on medical professionals to adhere to medical ethical standards. Whereas Edwardian-period medical ethics had been relatively unformed in Britain and Ireland, a more sophisticated (and enforced) interpretation of appropriate medical ethical behaviour was taking shape in the 1970s. Again, the excesses of Nazism had encouraged a post-war consensus on the need to regulate medical behaviour and discourage doctors from participating in torturous acts that held little clinical value. Public sensitivities towards allegations of medical cruelty were high in the postwar period. In the 1940s, Nazi physicians had performed medical experiments on prisoners in concentration camps involving depriving victims of oxygen until they died, deliberately infecting victims with infectious diseases such as typhus and cholera, and performing mass sterilisation. Although German physicians justified some of these experiments as having been essential to the war effort, many bore experimental purposes only. For instance, Josef Mengele collected twins from the concentration camps and transplanted their genitals in an attempt to create artificial Siamese twins. Mengele's work was inspired by racist and pseudoscientific eugenics and served no military purpose. ${ }^{66}$ The outcome of the Nuremburg trials of 1945-46, which saw twenty-three Nazi doctors being accused of involvement in human experimentation, led to the establishment of the Nuremberg Code. This emphasised issues such as patient consent. ${ }^{67}$ Yet human experimentation (typically undertaken on vulnerable groups such as orphans or black people) remained common internationally. ${ }^{68}$ The end result (sparked primarily by a 1966 exposé on human experimentation by American anaesthesiologist Henry Beecher) was a closer regulation of medical practice and a stricter imposition of ethics at the bedside. ${ }^{69}$ Modern bioethics developed in light of such problems. Heightened concern about dubious medical behaviour helped to solidify a sense that force-feeding constituted a breach of medical duty.

In the 1970s, prison medicine came under particular scrutiny. Rising numbers of long-term prisoners in that decade encouraged increased security and control in prisons. It transpired that prison doctors were regularly over-prescribing addictive drugs to control violent behaviour, performing questionable operations such as lobotomies to 'cure' criminal tendencies, and routinely categorising members of minority groups (such as black prisoners) as psychiatrically unstable. ${ }^{70}$ Force-feeding was now being performed in light of a broader critique of prison medicine, in a period when doctors were under increasing pressure to seek outside advice on the ethical aspects of their work rather than continue regulating 
themselves. ${ }^{71}$ Medical opinion on the ethical appropriateness of feeding prisoners against their will remained divided. In February 1974, eminent doctor and Conservative MP, Tom Stuttaford, suggested on BBC Radio Four news programme, The World at One, that force-feeding caused no physical suffering or permanent damage. Stuttaford added that the procedure only took five minutes and dismissed claims of torture as grossly exaggerated. ${ }^{72}$ But many doctors remained unconvinced. Considerable opposition arose from members of the profession who saw a severe lapse in ethical norms. The procedure had barely been improved upon since it had first been introduced. The substances fed to fasting prisoners now consisted of a concentrated blend of skimmed milk, minerals, and Complan, a nutritional supplement drink. The option of intravenous feeding was also available, although it tended not to be used as it required a drip being placed into the vein of a resisting prisoner for up to twenty-four hours. This could easily be ripped out. The nature of the force-feeding technologies remained just as intrusive as in the past, the procedure was so simple in nature that few innovations could be made.

In light of this absence of technological development, familiar ethical questions were posed. Firstly, was force-feeding safe? John Yudkin, Emeritus Professor of Nutrition at London University, publicly stated that force-feeding tended to be harmless, although he acknowledged that feeding tubes could accidentally slip into the windpipe instead of the gullet. Others were less convinced. Sat mournfully smoking a cigarette after visiting his daughters for the first time in a year, Albert Price announced to a televised press conference that 'the doctor-he punished them too. $\mathrm{He}$ mustn't be a very experienced man. He put the tube down the wrong way. ${ }^{73}$ Secondly, did force-feeding impact adversely on health? In January (after around a month of force-feeding), the Brixton Prison medical officer publicly announced that the sisters were fit and healthy, and had lost no weight in the previous week. He also denied that the procedure made the girls choke. ${ }^{74}$ However in a letter to the Guardian, prominent consultant pathologist David Stark Murray (former President of the Socialist Medical Association) asserted that force-feeding was physically dangerous and psychologically damaging. ${ }^{75}$ Thirdly, were prison doctors once again 'prostituting their profession' to the state and abandoning basic medical ethical principles? The New Law Journal pointed out that 'no-one is making them [the prisoners] undergo a hunger strike.' Dismissing notions of human rights, the journal commented, 'when the day comes that we behave coolly enough to have regard to such 'rights', it may be that we 
have gone too far down that road. ${ }^{, 76}$ In contrast, Donald Gould, medical correspondent in the New Statesman, took a more nuanced stance by referring to an apparent dual loyalty. Gould suggested:

When doctors force-feed a prisoner, therefore, they are acting as agents of the state, and not as servants of the patient in their care. The conflict between a doctor's duty on the one hand, and to his patients on the other, is growing all the time-doctors as a group must fiercely defend the principle that their duty is to their patients. ${ }^{77}$

The immediacy of republican violence, the construction of the female prisoners as monstrous individuals, and the self-imposed nature of their hunger strikes militated against universal condemnation. Even critics of force-feeding were careful to maintain that they held no sympathy for PIRA politics or violence. The mixed emotions produced by the Price sisters' medical encounters were notably evident in a discussion that took place in New Society. In January, Jacqueline Kaye, a member of the Joint Action Committee on the Hunger Strikers, penned a compassionate article that depicted deep levels of suffering at the hands of medical men. Citing excerpts from a letter sent by the sisters to their mother, she wrote:

The Price sisters, now being held in the hospital wing of an all-male prison, where most of the other patients are mentally ill, have described to their mother and sister the way they are fed every day. While they are held down on the floor of a bed, a wooden brick is passed through their teeth. Through the hole in the middle of the block, a greased public tube, of the kind normally used for pumping out the stomach of patients who have taken an overdose, is pushed down the throat and into the stomach. Water is then poured down and if the girls start to choke, it is withdrawn because it has gone down the windpipe. The girls begin to feel sick and often start to vomit around the tube. The liquid mixture-twenty-four fluid ounces of complan, milk, eggs and orange juice — gives about 1500 calories. It is poured directly, all at once, into the stomach. The girls were being fed twice a day, but damage to their throats led the prison doctor to decide to give them the feed once a day only. If they vomit, they are immediately fed again ${ }^{78}$

Kaye's article recounted a familiar repertoire of vomiting, physical force, technological invasion, choking, and inner pain. In writing her emotive account, Kaye intended to encourage her readers to consider the principles (and physical consequences) underlying force-feeding policies, regardless 
of its political contexts. Nonetheless, some readers remained unmoved. In a letter published in the following issue, one reader, L.G. Hart, asserted:

After Jacqueline Kaye's 'Feeding by Force', will you now be commissioning an article on those who suffered from the 'crude and often violent procedure' of injuring by car bomb? One title might be 'Lacerating by Force' ... there is something quite disturbing in the spectacle of your magazine presenting a one-sided view of this quartet's self-imposed suffering. ${ }^{79}$

Hart's letter exemplified the apathy felt among certain portions of the British population who failed to see why militant republicans deserved compassion, given that they seemed to care little for those whom they maimed and killed. Contradictory feelings existed towards the feeding of PIRA dissidents. Nonetheless, society was encouraged to reflect upon its liberal values and attitudes towards the wilful infliction of pain by medical professionals.

It is worth noting that the Price sisters held some sympathy for the doctors called upon to cure for them. They recognised that prison medical staff were not necessarily willing colluders with the government, even if this was a remarkably effective trope in republican propaganda. In their Prison Writings, the sisters wrote:

We've come to the conclusion that we must sympathise with the dilemma the doctors here find themselves in. We were just saying that they have all the training to counter illness, psychiatric illness, etc ... But how can they fight idealism? There's nothing about it in the medical books I'm sure. It's unfortunate that they should have to be used in this way because they bear us no grudge or us them. Our quarrel is with the Home Office only, and still I feel that it is a sad reflection on a very noble profession but then my opinion counts for nothing. As far as we are concerned our idealism is incurable, which from a medical point of view is frustrating for a dedicated doctor ${ }^{80}$

Nonetheless, prison doctors undoubtedly harmed the rebellious prisoners under their care. Indeed, they maintained medical reports on the Price sisters that seem to confirm certain aspects of Kaye's claims. They noted that the sisters accepted the use of the stomach tube throughout most of their protest and did not resist force-feeding. On 1 February 1974, the sisters screamed and resisted violently. They found themselves gagged; a radio was turned up high to conceal their screams during the feeding process. Yet the prison doctors noted that this was a one-off response to 
negative press publicity which they had read, it was an isolated situation. ${ }^{81}$ Private communication between the Home Office and the Director of Prison Medical Services later suggested that the sisters only acquiesced to being fed as 'the prisoner[s] finds the passing of the tube passed down the throat so unpleasant that after one or two days the struggling stops and the tube is passed easily and without discomfort'. In that sense, the Director was able to deny that 'force-feeding' was taking place, the fear of physical force was enough to discourage the sisters from resisting. ${ }^{82}$ However, the Price sisters' medical records indicate a large degree of vomiting, mouth abrasions, tooth damage, and fainting attacks. Their doctors insisted that vomiting was a self-induced attempt to rid the stomach of food. ${ }^{83}$ One reported that Dolours was particularly prone to vomiting and physical weakness, a problem which he attributed to her erratic mental state (as evidenced by her bouts of weeping and irritability) and her slender build. ${ }^{84}$ Despite such justifications, a vivid sense of pain and trauma in the prison medical encounter permeated their reports.

If prison doctors refused to admit that force-feeding was painful and traumatic, perhaps it could be proven some other way? In January 1974, a hundred demonstrators congregated outside Wormwood Scrubs at an event organised by the Irish Political Hostages Campaign. Some allowed themselves to be force-fed in the street. One elderly Wexford man, Charles O'Sullivan, needed to be taken to hospital after his feeding. Brendan McGill, national organiser of Sinn Féin in Britain, vomited as a doctor inserted a tube into his throat. Famed Irish actress, Siobhan McKenna, had to be restrained by Dublin actors Niall Buggy and Máire Ní Ghráinne after volunteering to be fed. ${ }^{85}$ The vulgarity of this public display of relentless vomiting was intended to draw public attention to the physical effects of force-feeding, highlighting the danger and discomfort of the procedure.

Despite mounting pressure, the higher echelons of the British medical profession remained relatively mute. In January, Irish Medical Times editor, Aidan Meade, called for the mass resignation of all Irish doctors from the British Medical Association unless the organisation demanded an immediate inquiry into force-feeding. Meade added that if this did not happen, Irish doctors should make representations to the World Medical Association about the abusive behaviour of British prison doctors. Underscoring his concern with ethical, rather than political, considerations, Meade added that 'let me say at the outset that I hold no brief for persons convicted of crimes of violence but I do feel that the dignity of the human being must be defended to the uttermost by all mankind and 
doctors in particular. ${ }^{86}$ Despite Meade's appeal, the Irish Medical Association decided by a considerable majority against condemning their British colleagues. ${ }^{87}$ One spokesman stated that 'terms like medical violence and forced feeding were emotive and conjured up a picture of brutality, violence and sadism in the minds of laymen', adding that other prisoners had left British prisons without having complained about being force-fed. ${ }^{88}$ Similarly, the British Medical Association remained silent on the matter, despite the medical implications of the sisters' feedings. It was mostly left to individual doctors to campaign against force-feeding.

In March 1974, a young London-based trainee G. P., Berry Beaumont, publicly announced that the sisters should be allowed to starve themselves to death if they wished. Berry insisted that 'it [force-feeding] may be justified in cases of insanity. But it is not in the case of two intelligent people who have made a decision not to eat until their legitimate demands have been met. ${ }^{89}$ But what motivated individuals such as Berry to protest? In an interview with the author, Berry recounted that she had become aware of the Price sisters' prison treatment in February after a conversation with a young colleague who was politically active in the Irish Political Hostages Campaign. Berry had limited interest in, or understanding of, the Northern Irish Troubles. Moreover, she had no personal contact with the two sisters. Her intervention, she recalled, stemmed purely from concern over what she saw as a severe lapse in medical ethics made worse by the relatively reasonable requests being made by the Price sisters to be transferred home. Notably, Berry was unaware at the time (and to date) of the commonplace nature of force-feeding in English prisons at the time, further highlighting how the Price sisters' prominent feedings drew public attention to a relatively veiled aspect of prison medicine. ${ }^{90}$

Throughout 1974, Berry attended meetings organised by the Irish Political Hostages Campaign as a spokesperson against force-feeding. She helped to arrange demonstrations and public rallies in London, Liverpool, and Dublin, at which she showed the funnels and tubes to passers-by. In May, Berry led a group of protestors to picket the headquarters of the British Medical Association in Tavistock Square, London, and delivered a letter signed by thirty-eight medical professionals to the Association's secretary, Derek Stevenson, calling for a public statement to be made condemning the practice. At this stage, the Price sisters had been forcefed for 175 days. Beaumont publicly insisted that force-feeding was medically dangerous, psychologically damaging, and ethically dubious, adding that it seemed clear that the procedure did not maintain health. Indeed, 
she claimed, the sisters had lost weight, their hair had fallen out, and their teeth had become loose. ${ }^{91}$ Berry remembered that 'the force-feeding demonstrations were quite potent actually-I like to think we made an impact on the BMA because we made demands on them to discuss it [force feeding] and we picketed outside the BMA for hours on the day that the ethicists were discussing it. ${ }^{92}$

Evidently, by the mid-1970s, force-feeding seemed increasingly at odds with contemporary notions of human rights, ethical behaviour, and modern liberal society for individuals such as Berry Beaumont. While the nature of the procedure had barely changed since its introduction into prisons in 1909, the socio-cultural climate that surrounded medical practice had. The publicity generated by the Price sisters' plight, combined with adjusting perceptions of human rights and medical ethics, created an environment in which force-feeding could be more effectively challenged. The numbers campaigning against the use of the procedure barely equalled their equivalents during the suffragette hunger strike campaign or following Thomas Ashe's prison death. Yet the backgrounds of those who did were far more diverse. Ideas had changed considerably about what constituted appropriate ethical behaviour and the extent to which pain should be willfully inflicted on human beings; even in relation to two of the most notorious and determined criminals in the English prison system.

\section{The Death of Michael Gaughan}

While a general sense existed that force-feeding was painful, degrading, and unethical, it took the death of a force-fed PIRA prisoner to break the reluctance of the Home Office to formally revoke its policies. In May 1974, Home Secretary Roy Jenkins announced that the low level of cooperation displayed by the Price sisters during the feeding process had led him to decide to end their force-feedings. ${ }^{93}$ In fact, private communication between the Home Office and Brixton Prison had suggested that the sisters were mostly compliant. Jenkins later recalled that he was felt under duress from PIRA (which was threatening retaliation) and members of the public (a possible reference to human rights and medical ethics activists). ${ }^{94}$ In the New Statesman, journalist and medical critic, Donald Gould, suggested that it was, in fact, the prison doctors who had refused to continue feeding. He cited the 'pain, the emotional agony and the denigration of human dignity' that surrounded the procedure and claimed 
that the doctors had 'finally had enough'. According to Gould, 'unless they are brutes, the nurses and doctors and wardens involved must be sick at heart. ${ }^{95}$ His statement seemed to confirm the viewpoint of the Lancet which, a week earlier, had suggested that the Brixton Prison medical officers would rather not force-feed given the choice, but felt obliged to carry out orders given by the Home Office. ${ }^{96}$ Contrarily, a statement made by Clare Price suggested that 'the last time he [the prison doctor] force-fed her, he nearly killed her.' ${ }^{97}$ While Gould's statement sought to affirm the humanity and decency of the doctors who participated in hunger strike management, Clare's more cynical announcement implied that the prison medical staff were more concerned with avoiding a death (and potential legal interventions) than with the welfare of the two sisters.

This policy change inevitably reignited discussion of the ethics of allowing prisoners to starve to death. It also raised issues over who would be held accountable. Five days after Jenkin's announcements, reports surfaced that the Price sisters-who had now been refusing to eat for 194 dayshad been given their last rites. ${ }^{98}$ While many insisted that responsibility for their pending deaths should rest with the sisters themselves, PIRA apportioned blame to the Home Office for refusing to grant the simple request of transporting the prisoners back home. A letter dispatched from Dolours, published in the Daily Express, read:

As we sit today, physically we are pretty worn out. Even to walk to the loo drains us and the least movement leaves my heart pounding like a big drum. Each day passes and we fade a little more but no matter how the body may fade, our determination never will. We have geared ourselves for this and there is no other answer.

Cognisant of the potential political ramifications of a death from hunger strike, Dolours added:

The Home Office say we are not near death. Well, if a couple of weeks isn't near enough for them, I don't know what will be. They'll never live down the stigma that they let people die rather than transfer them to another prison. How ridiculous they will look to the rest of the world. I am only sorry I won't be here to see it. ${ }^{99}$

Somewhat unsympathetically, the Daily Express declared that starving to death was not too much of an ordeal after all. After consulting Birmingham psychiatrist, Myre Sim, the newspaper announced that hunger subsides 
after the first few days of fasting and that 'it's not a difficult thing to fast to death once one has made up one's mind.' With reference to anorexia cases, Sim maintained that a lack of electrolytes (essential nutrients such as sodium and potassium) and vitamins dulls the senses and impairs intellectual ability. Nonetheless, this did not mean that hunger strikers became mentally ill. 'Being a fanatical member of the IRA', the Daily Express lamented, 'is not a certifiable illness'. ${ }^{100}$

However, interest in the Price sisters' plight rapidly subsided as another case of force-feeding hit the international headlines. Michael Gaughan had been born in Mayo but later moved to London. In 1971, he received a seven-year prison sentence for taking part in an armed robbery while involved with the Official IRA. In 1974, he went on hunger strike at Parkhurst alongside fellow republican, Frank Stagg, in protest against long periods of solitary confinement and a refusal to be granted political prisoner status. ${ }^{101}$ On 3 June (less than a fortnight after Jenkins announced that the Prices were no longer to be fed), Michael died after being force-fed. Until he died, Michael's hunger strike had received scant media attention, perhaps because he had not been involved in the recent spate of PIRA mainland bombings. His gender also undoubtedly made the hunger strike seem less emotive. Nonetheless, the circumstances surrounding his death, combined with the recent publicity awarded to the Price sisters, ensured that force-feeding swiftly returned to the forefront of public debate.

Suggesting that doctors had engaged in cruelty and torture, Michael's mother Delia announced in the Guardian following his death:

They force-fed him on Thursday and cut open all the back of his mouth. $\mathrm{He}$ showed it to me. His teeth were loose and there was the smell of death in the place. I hadn't seen him for three years-he never wanted me to see him in prison. I went to see him with my son John, and we just didn't recognise him. He was just like something out of a Nazi concentration camp. He was so thin, all skin and bone. He knew he was dying and he told me he wanted to be buried in Ireland. Why did they treat him like that? He was a gentle, refined boy and he'd only been in London six weeks when he was arrested. How can anyone treat a boy like that? There's more concern for cats and dogs than there is for people. ${ }^{102}$

Pat Arrowsmith reportedly went on hunger strike in sympathy with the remaining hunger strikers. Malachy Foots, spokesman for the Provisional Sinn Féin, publicly stated that 'Michael Gaughan's death is nothing less 
than an act of murder by Roy Jenkins. It has been seen in Ireland in the same light as if it has been caused by a bullet from a British Army rifle.' ${ }^{\text {'03 }}$

On 6 June, police reinforcements guarded Ryde Town Hall while an inquest took place in fear of PIRA retaliation. Home Office pathologist, Peter Puller, oversaw the proceedings. ${ }^{104}$ The jury reached an unsatisfactory verdict of death from 'bronchial pneumonia and malnutrition'. Declaring their objection, Michael's family insisted that death must have been caused by a feeding tube either rupturing Gaughan's stomach or piercing a lung. Debates on the true cause of Michael's death proliferated. The Irish Press contended that Michael had not died naturally from the effects of fasting, but instead from pneumonia. If this illness had been brought on by force-feeding, the newspaper insisted, then Michael was a victim of murder or manslaughter. ${ }^{105}$ Adopting a similar tone, Brendan Magill, British organiser of Sinn Féin, stated that:

The family are not at all satisfied about the death. We think the symptoms show that damage was done to Michael by force-feeding. After he was force-fed on Saturday he complained that something hurt him inside. We believe something may have ruptured in his stomach when the feeding tube was placed inside him. And there is the fact that pneumonia developed so quickly. If we find that, through negligence, the doctors at Parkhurst Prison murdered Mr Gaughan, they should answer for that negligence. It should be possible to charge them with manslaughter at the very least. ${ }^{106}$

Towards the end of June, a second jury concluded that Michael had died from self-neglect. Medical evidence suggested that Michael had been rational and aware of the consequences of refusing to eat. It added that Michael had refused to be fed with the less intrusive feeding cup and noted that his violent resistance had added unnecessary danger to a normally safe procedure. The prison doctor acknowledged that force-feeding was not without its risks but maintained that he had been forced to weigh the dangers accompanied with the procedure against the problem of a prisoner starving to death. ${ }^{107}$

Michael's death led to a turnaround in hunger strike management policies. Jenkins agreed to grant a prison transfer to the Price sisters, Feeney, and Kelly on the condition that PIRA did not step up its terror campaign, much to the wrath of the still unsympathetic Daily Express. ${ }^{108}$ In consequence of Michael's death, the medical profession came under increased pressure to decisively outline its stance on force-feeding. At their annual 
general meeting in Carraroe, Co. Galway, Acadamh na Lianna, a group of Irish speaking doctors, passed a resolution condemning force-feeding. ${ }^{109}$ The Irish Civil Rights Association, the Irish Political Hostages Committee, and the Association for Legal Justice all called for a public inquiry into force-feeding. ${ }^{110}$ Jenkins dismissed the need for such an inquiry. ${ }^{111}$ Throughout the summer, the British Medical Association came under further fire for refusing to condemn force-feeding. ${ }^{12}$ While expert opinion remained deeply divided at the Association's annual conference, representatives of the Prison Medical Service, including H.C. Milne, stated that it was nonsense to expect a doctor to stand by and watch a prisoner kill him or herself, an action which he deemed less ethical than force-feeding. Other doctors raised concern that prison doctors with PIRA sympathies might be inclined to let a prisoner die to help secure martyrdom. Yet the Association was primarily concerned with tackling accusations of medical negligence charged at members of its community, not with prisoner welfare. At the conference, the doctors voted to accept a statement of guidance which stated that doctors who force-fed would not be deemed guilty of misconduct by the General Medical Council. It also recognised that doctors could refuse to force-feed if he or she wished. ${ }^{113}$

Under considerable pressure, the British Medical Journal published an article on 29 June (shortly after Michael Gaughan's second inquest) which discussed the legal aspects of force-feeding and confirmed the status of prison doctors. The article contained a lengthy recital of the Leigh $v$ Gladstone case of 1909 which had affirmed the prison doctor's duty to keep fasting prisoners alive. While critical of the idea that prison doctors should help the state quell political opposition, the main thrust of the piece confirmed that doctors who force-fed were dutifully attending to the interests of patients. ${ }^{114}$ In an official statement issued in the following week, the British Medical Journal referred to the Declaration of Geneva (1947) of the World Medical Association which stated that 'the health of my patient will be my first consideration.' In light of this, it argued that 'artificial feeding' was compatible with human rights and medical ethical norms. Seemingly unaware of the extent of convict prisoner force-feeding, the statement read 'the total of cases in this country over the past forty years is small and most of the prisoners have been psychiatrically disturbed'. The Association also dismissed insinuations that force-feeding amounted to torture. ${ }^{115}$

Despite some degree of medical support for force-feeding, Jenkins announced on 17 July 1974 that mentally sound hunger strikers would 
be provided with food from now on and that 'health deterioration may be allowed to continue with medical intervention', in line with Scottish and Northern Irish policies. Jenkins' statement implied that force-feeding would no longer take place in English prisons. ${ }^{116}$ Essentially, Britain opted for a model of clinical independence. Force-feeding remained a clinical judgement rather than a legal requirement by law and could, in principle, continue. ${ }^{117}$ Throughout autumn, pressure was placed on British and Irish doctors to draft a declaration on force-feeding to be prepared in time for the World Medical Association's Ethics Committee in March 1975. ${ }^{118}$ Even despite Michael Gaughan's death, prison doctors continued to feed convict prisoners against their will in 1975, including Nathan Greenberg, an American citizen held in Wormwood Scrubs who fasted for over two months before his prison doctor authorised feeding. ${ }^{19}$ Notably, the Declaration had considerable input from members of the Irish Medical Association. All of the points made in the Irish submission were ultimately included in the new code of conduct. Upon its publication, SecretaryGeneral of the Association, Noel Reilly, announced that 'this is an ethical code for doctors and has all the force of such a code. Doctors who ignore it could be found guilty of unethical practice.' Reilly added that doctors who felt pressured by governments to force-feed would receive full support from the World Medical Association. ${ }^{120}$ In a letter to the Irish Press, the Irish Civil Rights Association welcomed the Declaration, stating that:

We pay tribute to those whose courage, spirit and will during several long months of brutal force-feeding drew worldwide attention and made it imperative that World Medical Association should lay down these strict ethical guidelines for members of their profession. That tribute we pay to: Marion and Dolours Price, Gerard Kelly, Hugh Feeney, Frank Stagg and to the memory of Michael Gaughan, who died under the cruel treatment of force-feeding. ${ }^{121}$

Ultimately, the Declaration played an important role in diminishing forcefeeding practices in prisons internationally. It also prompted considerable discussion in forums such as the Journal of Medical Ethics on the need for basic medical ethical principles to dictate prison medical practice and for physicians working in prisons to separate themselves from the 'dual loyalty' which many felt towards the ethical codes of their profession and the political needs of governments who might authorise their participation in force-feeding to quell political opposition. ${ }^{122}$ While force-feeding was, as 
always, seen as ethically dubious during the 1970s, the death of a force-fed prisoner-Michael Gaughan-now bore enough resonance to stimulate policy change and encourage the medical profession to adopt international guidelines. Penal discourses and technologies that had once held sway in English prisons were beginning to wane; the exertion of discipline and power upon the bodies of prisoners seemed increasingly questionable in a period that emphasised the importance of human rights and prisoner welfare and which questioned the nature of institutional power itself. Pain and emotional trauma seemed unacceptable in English prisons.

\section{Aftermaths}

The ending of force-feeding policies radically changed the dynamics of hunger strike management. Hunger strikers now had full reign to claim authority over their bodies without the threat of being fed. The authority of prison doctors to enforce discipline with their stomach tubes had been dramatically reduced. Unlike the battered corpse of Michael Gaughan-its facial markings unveiling the brutality of prison medicine-the corpses of those who were to die in Northern Irish prisons became imbued with emotive connotations of self-sacrifice and political desperation. As had been the case during the Irish War of Independence some fifty years earlier, doctors now adopted a less antagonistic role. In many ways, their role in hunger strike management was bypassed, food refusal evolved into a headon conflict between prisoners and politicians. Being no longer expected to use force, doctors reverted to a more therapeutic role. Yet if we posit that many prison doctors - even those who force-fed-genuinely saw their role as being to preserve life (rather than help enforce prison discipline), how did they respond to prisoners who expressed a determination to die? Could the idea of prisoners starving to death have emotional repercussions for both prison doctors and the public?

When Jenkins announced that force-feeding was to be no longer used in English prisons, a Coventry bus driver named Frank Stagg was on hunger strike at Parkhurst. Frank was serving a ten-year sentence for PIRA-related offences. Jenkins had omitted Frank from the concession package offered to the Prices, Feeney, and Kelly. Frank was from the Republic of Ireland. No rationale existed for transferring him to a Northern Irish prison. Nonetheless, Frank had garnered considerable attention as he had been on hunger strike alongside Michael Gaughan. During 1974, prison doctors force-fed Frank for sixty-eight days; the end result being a dislocated jaw, 
weakened digestive system, and physical debility. ${ }^{123}$ Mid-way through this protest, prison staff had persuaded Frank to intervene in Michael's hunger strike, although Michael had reportedly bemoaned: 'It's too late-they are killing me and have fractured my lung by the forced feeding. ${ }^{124}$ When Michael died, PIRA advised Frank to end his protest.

Frank Stagg was pivotal to the transition away from force-feeding as he staged numerous hunger strikes during a period of policy change. His experiences provided a harbinger of problems to come. In October 1974, Frank once again refused to eat in protest against intrusive strip-searches. Medical staff transferred him to an intensive care unit at Long Lartin Prison, Worcestershire. Frank had not fully recovered from his first hunger strike and was still receiving outpatient treatment for kidney and liver problems. ${ }^{125}$ Twenty-one days into Frank's renewed fast, his wife, Bridie, announced to the press that 'Frank is now too weak to get out of bed. $\mathrm{He}$ is only taking a small amount of water, because his lips are bleeding continuously and he has severe abdominal pains.' Frank's sister added that he was in a worse condition than he had been seventy days into his first hunger strike. ${ }^{126}$ Frank resumed eating after thirty-four days following an intervention from the Irish government. ${ }^{127}$

Frank commenced a further hunger strike in December 1975 alongside a number of other prisoners. ${ }^{128} \mathrm{He}$ was soon admitted to hospital suffering from vitamin deficiency, physical weakness, and fainting. Despite his frail condition, Frank refused medical examination. At times, he declined water believing that his doctors were surreptitiously adding vitamins. ${ }^{129}$ In mid-January, he wrote to his mother: 'I am extremely weak and shivering with cold. I have also had some dizziness as well, which is very unusual so early on. I am understandably in very poor shape physically after being in the punishment block for eight months and for the past three months I have had no exercise or fresh air.' During his various protests, Frank failed to regain weight or appetite and was blighted with kidney problems. ${ }^{130}$ Amnesty International protested that his death would be a humanitarian concern, given that Frank sought to draw attention to problems such as prolonged solitary confinement. ${ }^{131}$ Yet his self-imposed starvation ultimately attracted less humanitarian concern than the fate of force-fed prisoners. The situation was devoid of antagonistic doctors and perpetrated violence. Frank died on 12 February 1976 after surviving sixtytwo days without food. In the days that followed, Belfast was beset with bombings, shootings, hijackings, riots, burnt out factories, and a PIRA rocket attack on a British Army post. ${ }^{132}$ After death, Frank's body was a 
contested political artefact. His funeral caused controversy as family members disagreed about whether the corpse should be buried in a family or republican plot. Republicans waited at Dublin Airport for the corpse. The Irish government controversially re-directed the flight to Shannon Airport so that Stagg could be buried in the family plot (although republicans later stole his body and placed it in the republican plot). ${ }^{133}$

But who had been responsible for Stagg's slow, physical decay? Was it Stagg himself who had willingly inflicted violence on his own body fully cognisant of the likely consequences? Was it the British government who had prioritised political expediency over the death of one individual? Or was it PIRA who, in the public eye, supported physical self-sacrifice among its members, perceiving it as an embedded part of Irish republican mythology traceable to discernible events in the Irish past? Dublin-based newspaper, the Evening Herald, announced that:

And so the IRA have had their way. Frank Stagg has been slaughtered to suit their brutish schemes. There was no reason in the world why this unfortunate man should have died by hunger strike. His so called friends could have halted his march towards death with a single word. There is no mercy in the IRA, when it comes to using a human being to provide fodder for their murderous ambitions. ${ }^{134}$

Similarly, Irish Taoiseach Jack Lynch, speaking at an annual convention in Dublin, asserted:

The life of that young man could have been saved by a word from those who claim to be his leaders. These men, wherever they are, are only too willing to sacrifice the lives of their young subordinates, just as they order the indiscriminate taking of many innocent lives in the pursuit of an objective, which, by their evil deeds, they desecrate. ${ }^{135}$

Frank Stagg's body ultimately became imbued with multiple meanings, depending on the particular political perspectives of the actors involved, the search for culpability opened up manifold possibilities. Yet, unlike earlier incidences where the bodies of hunger strikers had been force-fed, damaged, and, in some instances, destroyed, the self-imposed nature of prison starvation went some way towards shielding governments and prison doctors from accusations of excessive force. Blame was now directed elsewhere. At an inquest which lasted for an hour, David John Gee, Professor of Forensic Medicine at University of Leeds, concluded 
that death had resulted from cardiac atrophy following malnutrition. The prison governor confirmed that Frank had been warned about the likely consequences of not eating. The coroner acknowledged that feeding prisoners against their will was inherently dangerous and supported the decision not to force-feed. Ultimately, the jury concluded that Frank had committed suicide. ${ }^{136}$ Unlike force-feeding, self-starvation was not a transgression of human rights or medical ethical norms. The act of dying itself was certainly imbued with political meaning. Corpses, when they emerged, became deeply contested. Yet many—such as Frank's-were soon forgotten about, their political impact remaining limited.

Few bodies are as contested in Irish history as that of Bobby Sands. His death was the end result of a series of controversies surrounding Northern Irish imprisonment. From 1971, the Northern Irish government housed politicised prisoners in Long Kesh/Maze Prison. Initially, the prison contained huts designed to hold eighty men, although the site was expanded throughout the 1970s. By the end of the decade, prisoners were accommodated in $\mathrm{H}$-shaped blocks and segregated according to their political orientation. ${ }^{137}$ Although Whitelaw had granted special category status to politically motivated prisoners in 1972, tacitly acknowledging that political motivations underpinned PIRA violence, the British government took steps to 'normalise' Northern Ireland from the mid-1970s. From 1976, all politicised prisoners were treated as ordinary criminals as part of an attempt to defuse the impression that a war was taking place in Northern Ireland. Considerable opposition arose to the government's refusal to grant special category status. ${ }^{138}$ Many prisoners rejected criminalisation policies by refusing to adorn the physical markings of criminal life, most notably the prison uniform. In September 1976, Ciaran Nugent refused to wear his uniform. He kept warm in his cell by wearing only a blanket; starting what became known as the 'blanket protest'. By 1980, almost 450 prisoners were 'on the blanket'. They found themselves subject to harsh punishment and severe loss of prison privileges. The blanket protest escalated into a no-wash protest when prisoners refused to shower unless prison staff provided them with a second towel to cover themselves while they washed. ${ }^{139}$

In October 1980, seven republican prisoners went on hunger strike. As one prisoner, Sean McKenna, lapsed into a coma in December, the British government appeared to concede to the prisoners' demands for the right to wear their own clothes, freely associate, organise their own leisure activities, to be granted a reduction of sentence, and to be exempt 
from prison work. Yet by January, it became clear that these demands had not in fact been conceded. ${ }^{140}$ During an internationally controversial hunger strike that followed from March 1981, ten republicans died: Bobby Sands, Francis Hughes, Patsy O'Hara, Raymond McCreesh, Joe McDonell, Martin Hurson, Kevin Lynch, Kevin Doherty, Tom McElwee, and Mickey Devine. ${ }^{141}$ Conceding to prisoner demands would have symbolically challenged the 'criminalisation' of PIRA members, acknowledging their cause as politically legitimate. ${ }^{142}$ Unlike earlier hunger strikes, the prisoners staged their protests successively in small groups, essentially producing a 'conveyor-belt of death'. Prime Minister, Margaret Thatcher, infamously adopted a hard-line stance. She adamantly refused to give way to the hunger strikers, choosing instead to let them die. ${ }^{143}$ It is worth noting that claims have since been made that PIRA could have stopped the hunger strikes if they wished, and should therefore assume responsibility. ${ }^{144}$ Nonetheless, since 1981 , the protestors have received much sympathy, with the predominant memory of the hunger strikes being one that demonises Thatcher for her intransigence.

But what issues surrounded the hunger striking body on a less symbolic or political level? The physical effects of hunger striking were similar to those experienced by republicans in the War of Independence; a litany of weight loss, sore throats, cracked skin, dizziness, painful eyes, and eventual descent into a coma from which most prisoners never awoke. ${ }^{145}$ Although those who passed away left little evidence of their experiences, accounts penned by survivors reveal deep levels of self-mutilation and self-inflicted bodily harm. Irish National Liberation Army prisoner Liam McCloskey later recalled:

On the forty-second day [of the hunger strike] my eyesight started to go. I was watching TV and the picture began to flicker. I was wondering if it was the TV or me and looked around and the whole room did the same. Just after that I was sick. That the beginning of a weeklong cycle when my eyesight began to slowly fade. This causes a seasickness effect. I was in bed all the time holding a wee bowl, vomiting up water and green bile which was very unpleasant. My eyesight started to go on Sunday, and by Friday I was constantly heaving and heaving. I thought that my whole insides would just drop out ... the next morning, Saturday, I woke up and I was blind, and because of that the sickness stopped. Around this time my bowels and co-ordination stated to go downhill. I didn't realise though because I was blind. ${ }^{146}$ 
Liam's experiences contrasted sharply with those of force-fed prisoners. McCloskey self-consciously allowed his basic functions-eyesight, bowel movements - to fail. The boundaries between the inside and outside of his body becoming increasingly blurred as physical sensations blended into one another. But the lack of medical intervention added particular dimensions to his account that brought to light the sacrificial nature of his protest. The fact that McCloskey allowed his health to decay to such an extreme level added weight to the view that Irish republicanism was a valid political cause. Such renderings of self-starvation drew attention to the political cause being fought for, rather than the brutality of medical interventions.

How was such an individual to be cared for? As hunger strike management policies changed, prison interactions adjusted. In many ways, the 1981 hunger strikes presented less human rights problems than protests involving force-feeding had, given that suffering was self-imposed rather than directly inflicted. Indeed, in June 1981, the European Commission on Human Rights ruled against the prisoners on each of their demands. ${ }^{147}$ Yet this did not entirely dissolve the ethical problems associated with hunger strike management. As in the past, self-starvation encouraged compassionate relationships to form between hunger strikers and those overseeing their health. Whereas force-feeding doctors had been demonised as unsavoury characters eagerly perverting the natural ethical inclinations of their profession, those caring for dying patients could be positioned (and position themselves) as caring-often distraught-individuals trapped in a professional dilemma. This revised medical role encouraged prisoners to empathise with their doctors and form less antagonistic relationships. Admittedly, this scenario depended heavily upon the particular personalities of those involved. Nonetheless, the absence of force-feeding undoubtedly produced a discernible shift in prisoner-staff relations.

It but is important to note that doctors who had force-fed during the Troubles were not entirely lacking compassion and a sense of ethical responsibility. Between 1974 and 1975, prison doctors held different opinions on force-feeding. Although republican propaganda typically portrayed prison doctors as sinister characters, the reality was far more complex. Some doctors vigorously opposed the use of the practice, others did not. Some objected to the enactment of violence on the bodies of prisoners, others saw their institutional role as compatible with institutional and political objectives. In an oral history interview undertaken some decades 
later, one prisoner reminisced on his experiences of being fed. In his statement, the former prisoner recalled high levels of physical force:

The doctor would come in with eight prison warders and he would order the prison warders to restrain me. What restraining me meant was lying flat on my arms making sure that I couldn't move, bending my neck by the hair over the bed ends - the top of the bed - to get a straight line down your throat so that they could force a tube down it. He then had to open my mouth. And your jaw is probably the strongest muscle that you have. And that became a violent episode which the doctor himself generally was involved in. so they would push your nose about, bleed our nose. Try and push your chin down. If that didn't work, they would pull back your lips to try and force you to open your lips. If that didn't work they would use forceps and run them up and down your gums until your gums bled to try to force you to open your mouth.

The former prisoner added:

This happened on a daily basis. So different days depending on your resistance. It was either up or down they would also then use a riles tube which is a very thin tube they used, I think, for intravenous drip. They would move it against the membrane at the back of your nose- a very sensitive part- to try and force a gag so you would open your mouth. If they got your mouth open at all, they forced a wooden bit in something like you would put in a horse with a hole in it. They would force that back and one of the prison warders would then hold that back and you wouldn't be able to move. It was quite a frightening experience. ${ }^{148}$

Evidently, this prisoner recounted his experiences of force-feeding as marred by physical violence and force, as a determined, but ultimately futile, struggle against bodily intrusion. It would be reasonable to assume that prison doctors were more willing to use force in the case of a male hunger striker. The former prisoner's resistance undoubtedly guaranteed a resort to violence that might not have occurred if he had passively accepted the stomach tube. Indeed, his resistance in itself helped to transform the act of force-feeding into a battle of wills between doctor and prisoner.

Notably, the ex-prisoner recalled that three of the ten prison doctors at Wormwood Scrubs refused to perform the operation for ethical reasons (or perhaps because they objected to the physical violence involved). $\mathrm{He}$ also recollected that, through reasoning and arguing, he dissuaded a 
further four medical staff from force-feeding. The remaining three, he suggested, firmly stood by their opinion that their role was to save life. Nonetheless, when a legal case against their actions went to court, he recalled that the remaining three doctors suddenly stopped feeding him. 'My question to them', he asserted, 'was: Where is your Hippocractic Oath if you are so convinced-if your conviction is-you are doing this to save my life as opposed to doing it for political reasons, then surely you should continue on (which they did not)? So I think that the dilemma answers itself.' To answer his rhetorical question, the former prisoner commented that many of the prison doctors had been recruited from the British Army and formed part of a military system in place to tackle PIRA activity. For this ex-prisoner, the political perspectives of the prison doctors influenced decisions made about medical intervention that ran against the grain of medical ethical norms. ${ }^{149}$ Nonetheless, the fact remains that a significant proportion of medical staff viewed force-feeding as unethical and refused to perform the practice due to a belief in its wrongness. They decided not to involve themselves in the political aspects of force-feeding or abandon the ethical norms that structured their work.

But how did prison doctors deal with the alternative option: Being unable to intervene as a patient under his care slowly died from a lack of food? This option subverted the disciplinary tendencies inherent in prison medicine to enact punishment on the body. Yet it was also emotionally traumatic for the prison doctors involved. Between 1980 and 1981, the Northern Irish Department of Health carefully considered the problem of hunger strike management. One former staff member later recounted the pressure placed on doctors forced to watch prisoners waste away. As he recollected, 'that caused enormous stress for all healthcare staff. There were doctors that found that just extremely difficult to deal with. It was seen regardless of all the political issues involved, it was seen that all the patients had that right to choose.' He recounted particular frustration for doctors when family members were called in to offer their opinion about whether a seriously ill hunger striker should be fed and refused, stating that they wanted their son to die for the cause. ${ }^{150}$ During the opening months of the hunger strikes, family members adhered to their relative's wishes against intervening should a prisoner fall into a coma. However, relatives began to intervene towards the end of the hunger strikes as it became apparent that the government was unlikely to compromise. ${ }^{151}$ Death seemed pointless. As the Long Kesh/Maze hunger strikes progressed-and as international interest began to wane-many parents saw the death of a son as futile. ${ }^{152}$ In September 1981, family members of IRA member Laurence 
McKeown, who had been fasting for seventy days, ordered medical treatment to be provided. ${ }^{153}$

The Department of Health expended considerable resources dealing with the protocols and ethics of over-seeing self-starvation. As a former staff member recalled, 'I mean this is my objective view, they couldn't have done more to handle it in an appropriate way for health professionals. It was unknown territory.' Indeed, as the staff member also acknowledged, prison doctors were not equipped with a full understanding of how the human body wastes away without food or intricate matters relating to under-nutrition. Physiological knowledge of human starvation was still relatively unformed. Instead, prison doctors relied on their own observations, powerless to intervene. Fasting prisoners were now treated in the prison hospital. Medical officers established a prisoner's capacity for rational judgement and obtained confirmation of their opinion from an outside consultant. They informed prisoners that medical supervision and food would be made available, and that medical officers were not required to force-feed. Starvation, they warned, might be allowed to continue without medical intervention. ${ }^{154}$ Publicly, the Home Office did not openly refer to the Declaration of Tokyo. Nor did it entirely rule out the possibility of force-feeding if a prison medical officer deemed it appropriate. ${ }^{155}$ Nonetheless, in practice, prison doctors refrained from administering food.

Did this new policy make the work of prison medical staff easier or more difficult? After all, prison doctors were no longer called upon to perform a painful and highly contested bodily intervention that cast negative light on their professionalism in the public eye. But was observing a decaying body that could potentially be saved more or less traumatic as resorting to violence to save life? The Long Kesh/Maze prison hunger strikes undoubtedly placed severe strain on prison staff members forced to work in an often hostile environment which, at worst, endangered their lives and those of their family members. ${ }^{156}$ Many PIRA prisoners acknowledged the precarious position of the doctors who cared for them. In an oral history interview, one former prisoner recalled that 'the hunger strike posed a lot of questions then because you are a doctor and people are dying around you and there is nothing medically wrong with them and then you feel powerless and all the rest of it.' Cognisant of the ethically problematic nature of force-feeding, he added that:

I would imagine that [force-feeding] would be contradictory to the Hippocratic Oath or to the essence of the Hippocratic Oath. During it [the hunger strike], every day we were just taken out and you were weighed, 
blood pressure taken and just generally checked your health and checked urine samples and all which I suppose even to show that we weren't eating because it would show up. ${ }^{157}$

Similarly, another former prisoner stated that 'I think that was a terrible time for everyone, maybe particularly the doctors ... because their total instinct is to save life and they were examining people who were starving themselves to death. And they did examine them. They didn't stand back from that. ${ }^{158}$ A further former republican prisoner recalled:

We got good care afterwards and I would say it was down to people like Dr Love ... we would have got examined by him every day for maybe a week ... he definitely had a warmth and a humanity about him. ${ }^{159}$

Hunger striking also raised complex questions about underlying medical problems that required treatment. Fourteen days into his hunger strike, Brendan McLaughlin agreed to receive treatment for a stomach ulcer. He was unable to sleep due to his stomach pains and was vomiting blood. A hospital consultant at Musgrave Park Hospital, Belfast, warned him that he would be dead within four or five days if he refused treatment. ${ }^{160}$ McLaughlin raised an intricate dilemma. In essence, the point of the hunger strike was to die. But what if a prisoner died of a cause other than starvation? What if his or her protest aggravated a pre-existing medical complaint? Hunger striking could also take its toll on the psychological well-being of prison doctors. One doctor, Dr Ross, suffered serious problems with his conscience as he felt that he should insert a drip into a prisoner who had fell into a coma. Ross firmly believed that it was his duty to intervene in cases of starvation. He shot himself in the head on 13 June 1981. ${ }^{161}$

Evidently, the transition to permitting self-starvation raised multiple questions for prison doctors about how to manage, regulate, and observe the bodies of prisoners intent on refusing food. Doctors could adopt an observational role only, abandoning tendencies shown throughout the century to assert their power by resorting to the stomach tube to restore institutional order. The act of observing decaying bodies produced complex emotional responses-in one instance-resulting in suicide. Even despite forming part of a politico-military system in place to address political dissidence, many medical workers found it impossible to entirely discard compassion and empathy, to force themselves to over-rule their basic medical ethical inclinations and refrain from intervening by supplying food. 


\section{Conclusion}

In the mid-1970s, a range of inter-connected circumstances led to the formal denouncement of prison force-feeding as ethically unacceptable. The renewal of Irish republican activity in Northern Ireland-which spilled over onto mainland Britain-resulted in a number of incidences where politicised individuals found themselves imprisoned in English prisons and force-fed. Prison practices came under scrutiny in the context of broader debates on how so-called terrorists should be dealt with, and the appropriateness of inflicting pain and suffering in a liberal culture increasingly concerned about infringements of civil liberties and human rights. While force-feeding was far from uncommon in mid-twentieth-century English prisons, the high public visibility of the Northern Irish conflict ensured high media interest. Moreover, the lengthy force-feeding of two young sisters who simply wished to be returned home to continue serving their sentences added affective dimensions to discussion of their institutional treatment, replete with discussion of the gendered dimensions of performing the act on two 'girls'. Indeed, the Price sisters provided the first newsworthy incidence of a prolonged period of female force-feeding since the suffragette period.

A particular socio-cultural milieu existed in the 1970s which made force-feeding appear unacceptable. Heightened concern over breaches of human rights (which incorporated prisoner rights) meant that accusations of torture were now thoroughly investigated by activist groups. Moreover, medical behaviour itself was subject to public questioning in the 1970s. Revelations of breaches of medical ethics had encouraged the development of a new agenda of bioethics that sought to structure medical behaviour and protect patient rights. These imperatives combined with pressure place on politicians to structure public opinion on forcefeeding. Nonetheless, it was ultimately the death of Michael Gaughan that garnered considerable political and media interest, coinciding as it did with a peak in public interest in force-feeding. Gaughan's death confirmed the long-standing view held by critics that force-feeding was dangerous and potentially life-threatening, not to mention an entirely inappropriate response to problems faced by politicised prisoners. While the British medical profession mostly concerned itself with protecting prison doctors from accusations of neglect, abuse, or manslaughter, the broader international community (immersed as it was with discussing problems such as medical participation in torture) took the opportunity 
to condemn force-feeding as an unacceptable method of dealing with prisoners involved in civil conflict and who were directly opposed to the government that had authorised, overseen, and supported their feedings.

\section{Notes}

1. James Welsh, 'The Problem of Torture', in Michael Peel and Vincent Lacopino (eds), The Medical Documentation of Torture (London: Greenwich Medical Media, 2002), pp. 1-19 on pp. 4-6.

2. www.wma.net/en/30publications/10policies/c18/index.html. Accessed 25 November 2014, 14.50.

3. John M. Regan, 'The 'O'Brien Ethic' as an Interpretative Problem', Journal of British Studies, 52:4 (October 2013), pp. 908-39.

4. Ken Kesey, One Flew over the Cuckoo's Nest (London: Pan Books, 1973 [1962]); Foucault, Discipline and Punish.

5. For an overview, see Thomas Hennessey, A History of Northern Ireland 1920-1996 (London: Macmillan Press, 1997), pp. 1-121.

6. David McKittrick and David McVea, Making Sense of the Troubles: A History of the Northern Irish Conflict (London: Viking, 2012 [2000]), pp. 30-60.

7. For discussion of political violence and fundamentalism, see Steve Bruce, 'Fundamentalism and Political Violence: The Case of Paisley and Ulster Evangelicals', Religion, 31:4 (2001), pp. 387-405.

8. McKittrick and McVea, Making Sense of the Troubles, pp. 61-87.

9. Robert W. White, 'From Peaceful Protest to Guerrilla War: Micromobilization of the Provisional Irish Republican Army', American Journal of Sociology, 9:6 (May 1989), pp. 1277-1302.

10. For insight into loyalist perspectives on the Troubles, see Peter Taylor, Loyalists (London: Bloomsbury, 1999).

11. R. J. Spjut, 'Internment and Detention without Trial in Northern Ireland 1971-1975: Ministerial Policy and Practice', Modern Law Review, 49:6 (November 1986), pp. 712-39 on p. 715.

12. Rod Thornton, 'Getting it Wrong: The Crucial Mistakes Made in the Early Stages of the British Army's Deployment to Northern Ireland (August 1969 to March 1972)', Journal of Strategic Studies, 30:1 (2007), pp. 73-107; McKittrick and McVea, Making Sense of the Troubles, pp. 77-87.

13. Robert W. White, 'Comparing State Repression of Pro-State Vigilantes and Anti-State Insurgents: Northern Ireland, 1972-75', Mobilization: An International Quarterly, 4:2 (Fall 1999), pp. 189-202.

14. See, for instance, David R. Lowry, 'Internment: Detention without Trial in Northern Ireland', Human Rights, 5:3 (Spring 1976), pp. 261-331. 
15. Laura McAtackney, An Archaeology of the Troubles: The Dark Heritage of Long Kesh/Maze Prison (Oxford: Oxford University Press, 2014), p. 18.

16. 'Hunger Strike in Support of Prisoner', Irish Times (26 May 1972), p. 9.

17. 'Prisoners on Hunger Strike Weakening', Irish Times (8 June 1972), p. 11.

18. Jonathan Moore, 'Paramilitary Prisoners and the Peace Process in Northern Ireland', in Alan O'Day (ed.), Political Violence in Northern Ireland: Conflict and Conflict Resolution (London: Praeger, 2007), pp. 81-94 on p. 86.

19. 'Prison Hunger Strike Ends Twelve Hours after Promise', Irish Times (21 June 1972), p. 1.

20. Flynn, Pawns in the Game, p. 131.

21. Moore, 'Paramilitary Prisoners', p. 86.

22. Coogan, The IRA, p. 294.

23. Flynn, Pawns in the Game, p. 147.

24. Kew, TS84/22, 'Price and Price v. Home Office', 2 April 1974.

25. Banerjee, Muscular Nationalism, pp. 122-31.

26. Maryann Valiulis, 'Neither Feminist nor Flapper: The Ecclesiastical Construction of the Ideal Irish Woman', in Diane Urquhart and Alan Hayes (eds), The Irish Women's History Reader (London: Routledge, 2000), pp. 168-78 on pp. 171-2.

27. Andrew Mangham, Violent Women and Sensation Fiction: Crime, Medicine and Victorian Popular Culture (Basingstoke: Palgrave Macmillan, 2007), pp. 7-22.

28. Elaine Farrell, 'A Most Diabolical Deed': Infanticide and Irish Society, 1850-1900 (Manchester: Manchester University Press, 2013), pp. 53-66.

29. Sim, Medical Power in Prisons, p. 74.

30. 'Victims Remember that Day Bombers Hit the Old Bailey', Daily Express (31 May 1974), p. 2.

31. 'Lest we Forget', Daily Express (1 June 1974), p. 10.

32. 'Comment', Kerryman (18 January 1974), p. 24.

33. 'Price Sisters to Continue Fast', Guardian (21 January 1974), p. 20.

34. 'Hunger Strikers', Kerryman (25 January 1974), p. 33.

35. 'Agony', Irish Press (7 February 1974), p. 3.

36. irishfreedom.net/IRPA/Reports $\% 20-\% 20 \% 20$ News/Marian $\% 20$ Price\%20Folder/Marian\%20Price.htm. Accessed 10 February 2015, 10.49 .

37. 'The Price Sisters', Irish Press (6 February 1974), p. 6.

38. Catherine Driscoll, Girls: Feminine Adolescence in Popular Culture and Cultural Theory (New York: Columbia University Press, 2002), p. 2.

39. Linen Hall Library, Belfast, Venceremos Sisters: Prison Writings of the Price Sisters (Anderstown: Cathal Brugha Cumann, 1974), p. v. 
40. Ibid., p. 5 .

41. Linen Hall Library, Belfast, An Plobacht: Special Supplement on the Winchester Hunger Strikers (1974), p. 2.

42. An Plobacht, p. 5.

43. An Plobacht, p. 3.

44. Joanna Bourke, What it Means to be Human (London: Virago Press, 2011), p. 70 .

45. See, among others, Johannes Morsink, The Universal Declaration of Human Rights: Origins, Drafting and Intent (Philadelphia: University of Philadelphia Press, 1999).

46. Hunt, Inventing Human Rights, p. 26.

47. See Pat Walsh, From Civil Rights to National War: Northern Ireland Catholic Politics, 1964-74 (Belfast: Athol Books, 1989); Bob Purdle, Politics in the Streets: Origins of the Civil Rights Movement in Northern Ireland (Belfast: Blackstaff Press, 1990); Simon Prince, Northern Ireland's'68: Civil Rights, Global Revolt and the Origins of the Troubles (Dublin: Irish Academic Press, 2007).

48. For contemporary analysis, see Mike Fitzgerald, Prisoners in Revolt (Harmondsworth: Penguin, 1977).

49. Priestley, Victorian Prisons Lives, pp. xi-xiv.

50. Sim, Medical Power in Prisons, p. 2.

51. Diarmaid Ferriter, Ambignous Republic: Ireland in the 1970s (London: Profile Books, 2012), p. 358.

52. 'Provisional Diet: Peter Chippendale on Forced Feeding', Guardian (21 December 1973), p. 13.

53. 'Court Move on Hunger Strikers Ruled Out', Irish Press (19 February 1974), p. 3.

54. 'Five IRA Bombers being Forcibly-Fed', Observer (2 December 1973), p. 3.

55. 'ICRA Backs Prisoners' Demands', Irish Press (29 December 1973), p. 3.

56. 'Justice Group Critical of Forced-Feeding', Irish Press (1 December 1973), p. 3.

57. 'Minister Burned in Effigy', Irish Independent (17 December 1973), p. 11.

58. 'Civil Rights Protest at British Embassy', Irish Independent (14 January 1974), p. 22.

59. 'The Price Sisters: Some Letters', Spare Rib, 24 (June 1974), p. 26.

60. J. Jeremy Wisnewski, Understanding Torture (Edinburgh: Edinburgh University Press, 2010), pp. 5-8.

61. Gary D. Solis, The Law of Armed Conflict: International Humanitarian Law in War (Cambridge: Cambridge University Press, 2010), p. 441.

62. Hunt, Inventing Human Rights, pp. 94-7.

63. Ibid., p. 140. 
64. 'Price Girls Tied Down, Says Father', Irish Independent (26 February 1974), p. 20.

65. 'Multiple Rape', Irish Independent (11 March 1974), p. 20.

66. See, among others, Proctor, Racial Hygiene; Nicosia and Huener (eds), Medicine and Medical Ethics in Nazi Germany.

67. Jonsen, A Short History of Medical Ethics, p. 100

68. See James H. Jones, Bad Blood: The Tuskagee Syphilis Experiment (New York and London: Free Press, 1992); Washington, Medical Apartheid, pp. 157-88; Hornblum, Newman and Dober, Against their Will.

69. Rothman, Strangers at the Bedside, pp. 85-148.

70. Sim, Medical Power in Prisons, pp. 103-28.

71. Wilson, Making of British Bioethics, pp. 24-63.

72. BBC Archives, Ulster Folk Museum, 'The World at One', I February 1974.

73. Chronicle Archives, 'Interview with Albert Price', Scene around Six, 25 February 1974.

74. 'SDLP', Irish Press (10 January 1974), p. 4.

75. 'Letters to the Editor', Guardian (30 March 1974), p. 14.

76. 'Standing Firm', New Law Journal, 124 (6 June 1974), pp. 513-14 on p. 513.

77. Donald Gould, 'Doctors and Force-Feeding', New Statesman (7 June 1974), pp. 789-90 on p. 790.

78. Jacqueline Kaye, 'Feeding by Force', New Society, 27 (24 January 1974), pp. 200-1 on p. 201.

79. L. G. Hart, 'Forced-Feeding', New Society, 27 (7 February 1974), p. 339.

80. Venceremos Sisters, pp. 9-10.

81. 'Price and Price v. Home Office'.

82. Kew, TS84/22, 'Letter from T. H. Williams to Duncan Watson', 11 December 1973.

83. Kew, TS84/22, 'Treatment, including Prescriptions-History and Progress of Case: Marion Price', 1973-4.

84. Kew, TS84/22, 'Treatment, including Prescriptions-History and Progress of Case: Dolours Price', 3 December 1973.

85. 'Siobhan McKenna is Restrained', Sunday Independent (20 January 1974), p. 3.

86. 'Force Feeding Protest Urged', Irish Press (26 January 1974), p. 3.

87. 'Doctor's Congress', Irish Independent (19 April 1974), p. 7.

88. 'Forced Feeding: IMA Stands Off', Irish Independent (19 April 1974), p. 7.

89. 'Let the Price Sisters Starve-Doctor', Daily Express (12 March 1974), p. 5. 
90. Author's interview with Berry Beaumont, 30 January 2015.

91. 'Fresh Protests', Guardian (6 May 1974), p. 5.

92. Author's interview with Berry Beaumont, 20 January 2015.

93. 'Price Sisters', House of Commons Debates (23 May 1974), vol. 874 cols 599-602.

94. John Campbell, Roy Jenkins (London: Random House, 2014), pp. 423-4.

95. Donald Gould, 'Doctors and Force-Feeding', New Statesman (7 June 1974), pp. 789-90 on p. 790.

96. Maurice Moore, 'Force-Feeding of Prisoners', Lancet, 303 (1 June 1974), p. 1109.

97. 'Last Rites for Sisters', Guardian (28 May 1974), p. 28.

98. 'Last Rites for Sisters', Guardian (28 May 1974), p. 28.

99. 'IRA Warns over Price Girls', Daily Express (31 May 1974), p. 2.

100. 'With a Hunger for Martyrdom, Death is No Longer a Torture', Daily Express (5 June 1974), p. 5.

101. Flynn, Pawns in the Game, p. 152.

102. 'Irish Prisoner Dies on Hunger Strike', Guardian (4 June 1974), p. 1.

103. Ibid., p. 1.

104. 'Alert for Inquest: Gaughan Reprisal Fear', Irish Press (6 June 1974), p. 1.

105. 'The Gaughan Funeral', Irish Press (19 June 1974), p. 10.

106. 'More Hope on Price Sisters', Guardian (7 June 1974), p. 24.

107. 'Self-Neglect Verdict at Gaughan Inquest', Irish Press (27 June 1974), p. 3.

108. 'Anger Over Sisters 'Deal': Five Demands by the Price Girls', Daily Express (10 June 1974), p. 1.

109. 'Forced-Feeding', Irish Press (4 May 1974), p. 4.

110. 'Hunger Striker Man Dies in Prison', Irish Times (4 June 1974), p. 9.

111. 'Forced-Feeding', House of Commons Debates (10 June 1974), vol. 874 cols 471-2W.

112. 'Forcible-Feeding: BMA Accused', Irish Press (27 June 1974), p. 4.

113. 'Force-Feeding: BMA Divide', Irish Independent (12 July 1974), p. 24.

114. 'The Law and Force-Feeding', British Medical Journal, i (29 June 1974), pp. 737-8.

115. 'Ethical Statement: Artificial Feeding of Prisoners', British Medical Journal, ii (6 July 1974), p. 52.

116. 'Prisoners (Artificial Feeding)', House of Commons Debates (17 July 1974), vol. 877 cols 451-5.

117. Lila Lewey, 'Force-Feeding: A Clinical or Administrative Decision?', Canadian Medical Association Journal, 116:4 (19 February 1977), pp. 416-17.

118. 'Plan Draft on Force Feeding', Irish Independent (8 October 1974), p. 2. 
119. 'Mr. Nathan Greenberg', House of Commons Debates (20 October 1975), vol. 898 cols 11-12W.

120. 'Doctors to 'Black' Force-Feeding?', Irish Independent (20 October 1975), p. 3.

121. 'Forced-Feeding', Irish Press (30 October 1975), p. 8.

122. Paul Bowden, 'Medical Practice: Defendants and Prisoners', Journal of Medical Ethics, 2:4 (December 1976), pp. 163-72.

123. 'Stagg's Hunger Fast Threat', Sunday Independent (16 June 1974), p. 4.

124. 'Stagg's Father Says: 'Thank God, It's Over', Connaught Telegraph (13 June 1974), p. 1.

125. 'Fears Grow over New IRA Fast', Guardian (28 October 1974), p. 26.

126. 'Hunger Striker Has Only Ten Days to Live', Irish Independent (28 October 1974), p. 7.

127. 'Dublin Helps End Stagg Fast', Irish Press (6 November 1974), p. 1.

128. 'Prisoner's Fourth Hunger Strike', Guardian (16 December 1975), p. 5.

129. PRONI, NIO/12/482, 'Letter from D. K. Middleton', 5 January 1975.

130. 'Hunger Striker Close to Death', Irish Press (16 January 1976), p. 7.

131. PRONI, NIO/12/482, 'Letter from Amnesty International to Roy Jenkins', 23 January 1976.

132. 'Rocket Raid by Provos', Sunday Independent (15 February 1976), p. 3; 'Bombing and Rioting', House of Commons Debates (19 February 1976), vol. 905 cols $1480-1$.

133. NAI, 2006/68/27, 'Death of Frank Stagg' 1976; NAI, 2007/116/771, 'Frank Stagg: Hunger Strike and Death in 1976', 1977; Flynn, Pawns in the Game, pp. 166-73.

134. Evening Herald, 12 February 1976.

135. PRONI, NIO/12/482, 'Points of View on Ireland', February 1976.

136. Kew, HO299/88, 'Note for the Record: Frank Stagg-Inquest', 17 February 1976.

137. For analysis of the H-blocks, see McAtackney, Archaeology of the Troubles, pp. 137-82.

138. See Declan Moen, 'Irish Political Prisoners and Post-Hunger Strike Resistance to Criminalisation', British Society of Criminology Conference: Select Proceedings Volume Three (2000), pp. 1-20.

139. O'Malley, Biting at the Grave, pp. 18-25.

140. Ibid., pp. 28-34.

141. Ibid., p. 64.

142. Aogán Mulcahy, 'Claims-Making and the Construction of Legitimacy: Press Coverage of the 1981 Northern Irish Hunger Strike', Social Problems, 42:4 (November 1995), pp. 449-67.

143. Hennessey, Hunger Strike. 
144. Richard O'Rawe, Blanketmen: An Untold Story of the H-Block Hunger Strike (Dublin: New Island, 2005); Richard O'Rawe, Afterliveas: The Hunger Strike and the Secret Offer that Changed Irish History (New York: Lilliput Press, 2011).

145. Beresford, Ten Men Dead, pp. 116-17

146. Allen Feldman, Formations of Violence: The Narrative of the Body and Political Terror in Northern Ireland (Chicago: Chicago University Press, 1991), p. 253.

147. O'Malley, Biting at the Grave, p. 191.

148. University of Ulster, Nuffield Trust Oral History Interviews (hereafter UU-NT), July 2003.

149. UU-NT, July 2003.

150. UU-NT, August 2004.

151. O'Malley, Biting at the Grave, pp. 64-5.

152. Ibid., p. 71.

153. 'Jail Fast Families: INLA Decide to Withdraw', Irish Press (7 September 1981), p. 1.

154. Kew, CJ4/3024, 'Letter from W. I. Davies to Mr Concannon', March 1976.

155. 'Prisoners (Artificial Feeding)', House of Commons Debates (4 March 1976), vol. 906 cols 676W.

156. See the account in William McKee, Governor: Inside the Maze (Dublin: Gill and Macmillan, 2009).

157. UU-NT, March 2003.

158. UU-NT, June 2004.

159. UU-NT, May 2003.

160. 'Doctors to Treat McLaughlin', Irish Press (27 June 198), p. 1.

161. UU-NT, August 2004.

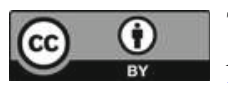

This chapter is distributed under the terms of the Creative Commons Attribution 4.0 International License (http://creativecommons.org/ licenses/by/4.0/), which permits use, duplication, adaptation, distribution and reproduction in any medium or format, as long as you give appropriate credit to the original author(s) and the source, provide a link to the Creative Commons license and indicate if changes were made.

The images or other third party material in this chapter are included in the work's Creative Commons license, unless indicated otherwise in the credit line; if such material is not included in the work's Creative Commons license and the respective action is not permitted by statutory regulation, users will need to obtain permission from the license holder to duplicate, adapt or reproduce the material. 


\section{Conclusion}

Since 1909, force-feeding has proven to be ethically contentious. Discussion of the issue has overlapped, at different historical junctures, with broader conversations about prisoner welfare, medical ethics, human rights, and civil rights. These discussions were set against historical contexts, including female suffragism, the Irish War of Independence, Irish Civil War, Cold War, and the Northern Irish Troubles. Public opinion on force-feeding was shaped by the exigencies of each of these particular contexts. Yet, regardless of historical setting, broadly similar ethical debates were played out. These primarily related to whether:

(i) force-feeding amounts to torture;

(ii) prison doctors have an ethical duty to preserve life; and

(iii) the state has the right to over-rule medical decision-making to preserve the lives of prisoners who refuse to eat.

Despite the World Medical Association formally declaring force-feeding as unethical in 1975, the very same questions have once again re-emerged during the so-called 'War on Terror'. Guantánamo Bay is the latest space in which governments have chosen to tackle the problem of prison hunger strikers with the stomach tube. Numerous critics have rallied to denounce the re-emergence of force-feeding and situated the practice within broader institutional problems such as the loss of basic human rights and dignity. 
Although suffragette force-feedings retain a prominent place in public perceptions of the history of the practice, this study has revealed a far wider story. Using Britain, Ireland, and Northern Ireland as a case study-a geopolitical space in which force-feeding debates were rehearsed throughout the twentieth century - this study has revealed a far more complex, multifaceted history. It has also addressed key questions posed about forcefeeding with the hope of broadening present-day discussions being waged by bioethicists and human rights campaigners. Force-feeding first emerged as a contentious issue in England during 1909 when suffragette prisoners, including Mary Leigh, were fed with a stomach tube against their will. Little did the Home Office know that its decision would instigate over a century of heated conversation about the ethical implications of force-feeding. Suffragettes were fed in a more disciplinary socio-cultural environment than exists today, one in which prisons still relied heavily on Victorian moral principles and negative gendered presumptions perpetuated by the medical profession itself. The suffragettes made claims about force-feeding that still resonate today. They pointed out that providing 'patients' with medical treatment without their consent constitutes a violation of basic medical ethical principles; that prison doctors often feed prisoners in an intimidating and degrading manner; and that the forceful insertion of a feeding tube can cause serious, and lasting, physical and emotional damage, even death.

The Home Office stopped feeding suffragettes as the First World War commenced. Yet the British government had by now realised the effectiveness of force-feeding in quelling prison rebellions being staged by politicised prisoners. It saw no reason not to force-feed hunger striking republican prisons in sites such as Mountjoy Prison, Dublin, during the tumultuous years leading up to the War of Independence and the Civil War. But force-feeding took on new meanings in revolutionary-period Ireland. It became upheld as a telling example of British aggression on Irish soil, as a hostile act that ultimately killed a leading Irish republican: Thomas Ashe. From 1917, force-feeding was rarely performed in Ireland. Yet the state only abandoned the practice in Ireland due to the political meanings that had become associated with the stomach tube and the potential social unrest that have ensued should further prisoners die. The government was less concerned with the medical ethical implications of force-feeding prisoners (as demonstrated by the ongoing use of the 
practice in English prisons). A general impression exists that the British government was willing to allow hunger strikers to die during the War of Independence, as demonstrated by the high-profile positioning of the 1920 death of Terence MacSwiney in the Irish historical psyche. In reality, thousands of imprisoned hunger strikers were released prior to completion of their sentence in this period. The government allowed their bodies to waste and decay, but rarely let them be entirely eradicated through the act of dying. Indeed, and perhaps ironically, it was the Irish government of the 1940s who had few qualms about letting imprisoned republicans starve themselves to death if they wished.

In twentieth-century England, force-feeding continued to be seen as an appropriate, and highly effective, means of tackling prisoner hunger striking. Inspired by an increasingly fashionable form of prison protest, numerous First World War conscientious objectors decided to refuse food to protest against the harsh, violent institutional conditions which they encountered. Indeed, the context of war provided a setting that supported the use of violence against those who seemed to pose a threat to the military cause. While this group of prisoners elicited considerable media attention, even in a climate of imposed censorship, the same could not be said for the large number of convict prisoners who chose to protest by the simple act of refusing to eat throughout the twentieth century. Convict prisoners went on hunger strike to protest against an array of conditions including adverse institutional conditions, excessive punishments, poor quality diets, or simply due to a desire to attract attention and prove their innocence to the public. Yet it tended to be only individuals who formed part of a cohesive group who attracted public interest, such as Cold Warperiod peace protestors. The protests of most hunger strikers passed barely noticed. They were force-fed behind the secretive walls of the prison; their protests were swiftly ended by the forceful insertion of a stomach tube.

Public debate on the ethical implications of force-feeding was only truly reignited in the 1970s during the Northern Irish Troubles. The feedings of Marian and Dolours Price between 1973 and 1974 captured international attention. Although the gender and age of these hunger strikers played an important role, force-feeding was now being discussed in a context that emphasised the importance of human, prisoner, and patient rights. The formation of the modern human rights and bioethics movements provided a suitable setting for the practice to be formally denounced. From 
the mid-1970s, prisoners were no longer fed against their will. Yet prisoners continued to hunger strike. Allowing starvation to run its natural course presented new medical, bodily, and political problems. Rather than being subjected to the inherent violence of force-feeding, hunger strikers were now allowed to perpetrate violence on their own bodies. The issue of force-feeding had finally been closed, so it seemed. At least until the American government once again resorted to the practice at the start of the twenty-first century.

To connect to present-day concerns, this study has focused on three key areas: prisoner experiences, medical ethics, and public responses. In all of the historical contexts discussed in this study, prisoners portrayed forcefeeding as painful, degrading, and emotionally traumatic. Many claimed that the insertion of a stomach tube was accompanied by verbal and physical abuse, restraint, and intimidation. These insinuations about prison medical encounters ran counter to government suggestions that 'artificial feeding' was safe, harmless, and ethically unproblematic. Undoubtedly, many prisoner accounts were exaggerated, particularly those that served propaganda purposes at the time. Yet they were remarkably consistent. It is hard to imagine that having a stomach tube forcefully inserted into one's body and food poured into the stomach would not be painful, physically and emotionally. Yet force-feeding has been performed-and still is at Guantánamo-in a western socio-cultural context that abhors the idea of needless pain being inflicted upon vulnerable individuals, one that shares cultural sensitivities towards torture and brutality. The harsh treatment of politicised prisoners is, supposedly, something confined to eastern or third world countries, not in the seemingly civilised west. For such reasons, force-feeding causes emotional conflict among the public. It is generally performed to support wars and conflicts which, at their core, are being waged to protect western liberal culture. Yet, today, force-feeding directly contravenes the basic underlying principles of 'civilised' culture; it seems to draw us closer to the supposed violence of alien, non-western societies whom we are waging war against. An examination of prisoner experiences draws us into the inner life of the prison, illuminating the physical and emotional landscape that surrounds hunger strikers.

Although normally discussed by historians in terms of its political implications, prison hunger striking is undoubtedly a medical problem. Hunger strikes, at their core, are about bodies, emotions, and ethics. Since 
1909, prison doctors have been called upon to care for starving prisoners, whether by using stomach tubes or monitoring the health of starving prisoners. Many were cast as aggressive individuals willing to collude with government agendas of subduing recalcitrant politicised prisoners. Yet the reality is undoubtedly more complex. Doctors, such as Raymond Dowdall, seem to have resorted to the stomach tube with remarkable vigour; his attitude towards prisoners was inflected by the broader contexts of the Easter Rising and Anglo-Irish conflict. But it is reasonable to assume that many doctors truly believed that they had a medical ethical duty to preserve the lives of prisoners who might otherwise die from starvation. Force-feeding was certainly an unpleasant task, but was it really any less pleasant than watching bodies decay and death occur? Others perhaps had mixed emotions; personal considerations such as avoiding legal action undoubtedly influenced decisions made to feed. Today, doctors who force-feed at Guantánamo are often accused of complicity with government agendas relating to the 'war on terror'. Yet historical analysis reveals diversity of opinion and willingness to force-feed.

Public opposition has always coalesced around ethical considerations, and still does. Suffragettes, Irish republicans, convict prisoners, and PIRA members all elicited support even from individuals who had no enthusiasm whatsoever for the particular political agendas of hunger strikers. Indeed, many deplored the violence being waged by political militants. Nonetheless, they formed an emotional connection with prisoners whom they imagined to be deeply suffering, their sensitivities to pain encouraged them to speak out against force-feeding and protect the vulnerable. Situating force-feeding debates in particular historical and socio-cultural contexts helps us to understand the nature of this opposition. Yet, even when diversity of medical opinion is taken into account, historical analysis seems to make clear that force-feeding has held clear disciplinary value (as exposed by an examination of convict prisoner feedings); that politicised prisoners are vulnerable to being fed in a violent, degrading manner; that force-feeding has proven itself to be potentially unsafe even in the most careful of medical hands; and that the practice clashes with western sensitivities towards pain and torture. Moreover, today, force-feeding is at odds with a general drive towards patient autonomy which occurred from around the 1980s which began to prioritise the rights of the comatose and other patient groups to be able to die, or refuse nourishment, if they 
wished (or if their representatives wished). Medical paternalism is meant to have given way to patient autonomy which, in turn, highlights the capacity of patients to choose their own direction and, in some instances, to starve themselves to death.

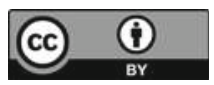

This chapter is distributed under the terms of the Creative Commons Attribution 4.0 International License (http://creativecommons.org/ licenses/by/4.0/), which permits use, duplication, adaptation, distribution and reproduction in any medium or format, as long as you give appropriate credit to the original author(s) and the source, provide a link to the Creative Commons license and indicate if changes were made.

The images or other third party material in this chapter are included in the work's Creative Commons license, unless indicated otherwise in the credit line; if such material is not included in the work's Creative Commons license and the respective action is not permitted by statutory regulation, users will need to obtain permission from the license holder to duplicate, adapt or reproduce the material. 


\section{BiBLIOGRAPHY}

\section{Archival Material}

(i) National Archives, Kew

Criminal Justice papers

Colonial Office papers

Home Office papers

Metropolitan Police Office papers

Prison Commission Office papers

Treasury Solicitor's Office papers

(ii) National Archives of Ireland

2006 files

2007 files

Department of Taoiseach files

General Prison Boards

Online census

President of Ireland files

S11369/9, 'Letter from M. H. O'Connor to Military Governor', 13 November 1922.

(iii) Public Record Office of Northern Ireland

Cabinet Office files

Northern Ireland Office files

'Letter from Constance Markievicz from North Dublin Internment Camp to Unknown Recipient', 1923.

(iv) National Library of Ireland

MS44.612, 'Account of the Forcible Feeding at Mountjoy Prison resulting in the Death of Thomas Ashe', 20-25 September 1917

(C) The Author(s) 2016

I. Miller, A History of Force Feeding,

DOI 10.1007/978-3-319-31113-5 
(v) University College Dublin archives Terence MacSwiney papers

(vi) Linen Hall Library, Belfast, Archives (pamphlet) Venceremos Sisters: Prison Writings of the Price Sisters (Anderstown: Cathal Brugha Cumann, 1974)

(vii) BBC Archives, Ulster Folk Museum

The World at One

(viii) Chronicle Archives

Scene around Six

(ix) Ulster University/Nuffield Trust Private Archives

'Transcript of Interview with Dr P. McClements', 5 August 2004

'Transcript of Interview with Gerard Kelly', 9 July 2003

'Transcript of Interview with John Steele', 9 June 2004

'Transcript of Interview with Laurence McKeown', 7 March 2003

'Transcript of Interview with Raymond McCartney', 7 May 2003

\section{Newspapers}

An Plobacht

Birmingham Mail

Connaught Telegraph

Cork Examiner

Daily Express

Daily Mirror

Evening Herald

Guardian/Manchester Guardian

Irish Citizen

Irish Independent

Irish Press

Irish Times

Kerryman

King's Co. Independent

Observer

Spare Rib

Sunday Independent

Times

Votes for Women

\section{OfFicial Documents}

Dáil Éireann Debates

Hansard (House of Commons Debates) 
Minutes of Evidence of the Royal Commission on the Care and Control of the FeebleMinded Volume III, Commons, Reports of Commissioners, 1908 [Cd. 4215], p. ix.

Report of the Commissioners of Prisons and Directors of Convict Prisons for the Years 1939-41, Reports of Commissioners, 1945-6, [Cmd. 6820], xiv.281.

Report of the Commissioners of Prisons and the Directors of Convict Prisons, with Appendices, for 1912-13, Reports of Commissioners, 1914, [Cd. 7092, 7093], xlv.i. Seanad Eireann Debate

Stormont Papers

\section{Bureau of Military History Archives}

Witness Statement 355, Joseph Furlong Witness Statement 517, Maurice Crowe Witness Statement 671, Patrick Rankin Witness Statement 779, Robert Brennan Witness Statement 802, Sean Prendergast Witness Statement 836, Seán Moylan Witness Statement 942, Patrick J. Berry Witness Statement 1093, Thomas Treacy Witness Statement 1135, William McNamara Witness Statement 1209, Stephen Keys Witness Statement 1348, Michael Darven Witness Statement 1393, Edmond McGrath Witness Statement 1415, Michael Hartney Witness Statement 1474, Eamon O'Dwyer Witness Statement 1702, Seán O'Carroll

\section{WEBSITES}

america.aljazeera.com

amnestyusa.org

emotionsblog.history.qmul.ac.uk

hrw.org

irishfreedom.net

reprieve.org.uk

soviet.ie

spartacus-educational.com

wma.net 


\section{Primary Sources}

A Catholic Priest. (1920). The ethics of hunger striking. London: Sands and Co.

Allen, V. L. (1958). The National Union of police and prison officers. Economic History Review, $11(1), 133-143$.

Anon. (1893). Five years penal servitude. London: Routledge.

Anon. (1903). Editorial. British Journal of Nursing, 31, 231-232.

Anon. (1909). Fasting prisoners and compulsory feeding. British Medical Journal, ii, 1099.

Anon. (1910). Forcible feeding. British Medical Journal, $i, 50$.

Anon. (1945). Our prison system. Lancet, 246, 145-146.

Anon. (1947). H. M. Prisons in the war years: Report for 1942-4. British Medical Journal, $i, 304-305$.

Anon. (1974a). Ethical statement: Artificial feeding of prisoners. British Medical Journal, ii, 52.

Anon. (1974b). Standing firm. New Law Journal, 124, 513-514.

Anon. (1974c). The law and force feeding. British Medical Journal, i, 737-738.

Ashe, T. (1917). The death of Thomas Ashe: Full report of the inquest. Dublin: J. M. Butler.

Babington, A. (1968). The power to silence: A history of punishment in Britain. London: Robert Maxwell.

Bast, T. H. (1926). The life and times of Adolf Kussmaul. New York: P. B. Hoeber.

Benedict, F. G. (1915). A study of prolonged fasting. Washington, DC: Carnegie Institute of Washington.

Bowden, P. (1976). Medical practice: Defendants and prisoners. Journal of Medical Ethics, 2(4), 163-172.

Brockway, F. (1942). Inside the left: Thirty years of platform press prison and parliament (p. 91). London: Allen and Unwin.

Catchpool, C. (1941). Letters of a prisoner: For conscience sake. London: George Allen and Unwin.

Cole, R. H. (1924). Mental diseases: A textbook of psychiatry for medical students and practitioners. London: University of London Press.

Coyle, A. (1921). Evidence on conditions in Ireland comprising the complete testimony, affidavits and exhibits presented before the American Commission on conditions in Ireland. Washington, DC: Bliss Building.

Fichner, V. (1968 [1927]). Memoirs of a revolutionist. New York: Greenwood Press.

Fitzgerald, M. (1977). Prisoners in revolt. Harmondsworth: Penguin.

Fox, R. M. (1930). Drifting men. London: Leonard and Virginia Woolf.

Gallagher, F. (2008 [1967]). Days of fear: Diary of a 1920s hunger striker. Dublin: Mercier Press.

Gannon, P. J. (1920). The ethical aspect of the hunger strike. Studies: An Irish Quarterly Review, 9(35), 448-454. 
Gordon, M. (1922). Penal discipline. London: Routledge and Sons.

Gould, D. (1974, June 7). Doctors and force feeding. New Statesman, 789-790.

Hart, L. G. (1974). Forced feeding. New Society, 27, 339.

Herschell, G. A. (1903). Manual of intragastric technique. London: H. J. Glashier.

Hobhouse, S., \& Brockway, A. F. (1922). English prisons today. London: Longmans, Green.

Kaye, J. (1974). Feeding by force. New Society, 27, 200-201.

Kesey, K. (1973 [1962]). One flew over the cuckoo's nest. London: Pan Books.

Keys, A. (1950). The biology of human starvation. Minneapolis: University of Minnesota Press.

Lewey, L. (1977). Force feeding: A clinical or administrative decision? Canadian Medical Association Journal, 116(4), 416-417.

Lytton, C. (1988 [1914]). Prisons and prisoners: The stirring testimony of a suffragette. London: Virago.

Masterton, J. P., Dudley, H. A. F., \& Sheila, M. R. (1963). Design of tube feeds for surgical patients. British Medical Journal, ii, 909-913.

Moore, M. (1974). Force feeding of prisoners. Lancet, 303, 1109.

Moxey, D. A. (1872). Feeding by the nose in attempted suicide by starvation. Lancet, 100, 444-446.

Moxon, F. (1914). What forcible feeding means. London: The Women's Press.

Niles, G. M. (1914). The diagnosis and treatment of digestive diseases. London: Henry Kimpton.

O'Cathasaigh, S. (1917). The story of Thomas Ashe. Dublin: Fergus O'Connor.

Peake, A. S. (1918). Prisoners of hope: The problem of the conscientious objector. London: G. Allen and Unwin.

Prewer, R. R. (1974). The contribution of prison medicine. In L. Blom-Cooper (Ed.), Progress in penal reform (pp. 116-128). Oxford: Clarendon Press.

Prison Medical Reform Council. (1943). Prison medical service: Report of an enquiry conducted by Roger Page into the medical service of H. M. Prisons. London: Prison Medical Reform Council.

Ruggles-Brise, E. (1921). The English prison system. London: Macmillan and Co. Saundby, R. (1902). Medical ethics: A guide to professional conduct. Bristol: John Wright and Co.

Savage, G. (1912). The case of William Ball. London: H.M.S.O.

Savill, A. F., Mansell-Moullin, C., \& Horsley, V. (1912). Preliminary report on the forcible feeding of suffrage prisoners. Lancet, 180, 549-551.

Shaw, T. C. (1913). The psychology of the militant suffragette. Lancet, 181, 1415.

Spencer, J. C. (1965). Problems in transition: From prison to therapeutic community. In P. Halmos (Ed.), Sociological studies in the British penal services (pp. 13-30). Keele: University of Keele.

Stoddart, W. H. B. (1926). Mind and its disorders: A textbook for students and practitioners of medicine. London: $\mathrm{H}$. K. Lewis. 
Turnbull, A. R. (1895). Some remarks on the forcible feeding of insane patients. Journal of Mental Science, 41(175), 646-656.

Waters, J. (1918). The morality of the hunger strike. Irish Ecclesiastical Record, $5(7), 89-108$.

Wright, A. E. (1913). The unexpurgated case against woman suffrage. London: Constable.

\section{SECONDARY SOURCES}

Agamben, G. (2005). States of exception. Chicago: University of Chicago Press.

Alberti, F. B. (2010). Matters of the heart: History, medicine and emotion. Oxford: Oxford University Press.

Alston, C. (2014). Tolstoy and his disciples: The history of an international movement. London/New York: I. B. Tauris.

Anderson, P. (2004). 'To lie down to death for days': The Turkish hunger strike 2000-2003. Cultural Studies, 18(6), 816-846.

Annas, G. J., Crosby, S. S., \& Glantz, L. H. (2013). Guantánamo Bay: A medical ethics-free zone? New England Journal of Medicine, 369, 101-103.

Anon. (1995). Assistance in hunger strikes: A manual for physicians and other personnel dealing with hunger strikers (P. Cooper, Trans.). Amersfoort: Johannes Wier Foundation.

Anon. (1997). Hunger strikes: Understanding the underlying physiology will help doctors provide proper advice. British Medical Journal, 315, 829-830.

Anon. (2000). Rethinking the role of tube feeding in patients with advanced dementia. New England Journal of Medicine, 342(3), 206-210.

Anon. (2004). Doctors and the war on terrorism. British Medical Journal, 329, 66.

Anon. (2005). The Guantánamo prisoner hunger strike and protests February 2002August 2005: A special report by the center for constitutional rights. New York: Center for Constitutional Rights.

Anon. (2006). Force feeding and restraint of Guantánamo Bay hunger strikers. Lancet, 367, 811.

Anon. (2013). Ethics abandoned: Medical professionalism and detainee abuse in the war on terror. New York: Institute on Medicine as a Profession.

Baker, R. B. (1995). The discourses of practitioners in nineteenth- and twentiethcentury Britain and the United States. In R. B. Baker (Ed.), The codification of medical morality: Historical and philosophical studies of the formalization of western medical morality in the eighteenth and nineteenth centuries Volume Two: AngloAmerican medical ethics and medical jurisprudence in the nineteenth century (pp. 446-464). Dordecht: Kluwer.

Banerjee, S. (2012). Muscular nationalism: Gender, violence and empire in India and Ireland, 1914-2004. New York/London: New York University Press. 
Başoğlu, M. (2007). Torture vs other cruel, inhuman and degrading treatment. Archives of General Psychiatry, 64, 277-285.

Başoğlu, M., Yetimalar, Y., Gürgör, N., Büyükçatalbaş, S., Kurt, T., SeÇil, Y., \& Yeniocak, A. (2006). Neurological complications of prolonged hunger strike. European Journal of Neurology, 13(10), 1089-1097.

Bearman, C. J. (2005). An examination of suffragette violence. English Historical Review, 120, 365-397.

Begg, M. (2007). Enemy combatant: The terrifying true story of a Briton in Guantánamo. London: Pocket Books.

Beresford, D. (1994 [1987]). Ten men dead: The story of the 1981 hunger strike. London: HarperCollins.

Bew, P. (1994). Ideology and the Irish question: Ulster unionism and Irish nationalism, 1912-16. Oxford: Clarendon Press.

Bibbings, L. S. (2009). Telling tales about men: Conceptions of conscientious objectors to military service during the First World War. Manchester: Manchester University Press.

Biggs, M. (2007). The rationality of self-inflicted sufferings: Hunger strikes by Irish Republicans, 1916-23. Sociology Working Papers, 3, 1-24.

Bloche, M. G., \& Marks, J. H. (2005). Doctors and interrogators at Guantánamo Bay. New England Journal of Medicine, 353(1), 6-8.

Blumberg, J. J. (1988). Fasting girls: The emergence of Anovexia Nervosa as a modern disease. Cambridge, MA/London: Harvard University Press.

Boddice, R. (Ed.). (2014). Pain and emotion in modern history. Basingstoke: Palgrave Macmillan.

Boulton, D. (1967). Objection overruled. London: MacGibbon and Kee.

Bourke, J. (2011). What it means to be human. London: Virago Press.

Bourke, J. (2014). The story of pain: From prayer to painkillers. Oxford: Oxford University Press.

Bowman, T. (2012). Carson's army: The Ulster Volunteer Force, 1910-22. Manchester: Manchester University Press.

Breathnach, C. (2014). Medical officers, bodies, gender and weight fluctuation in Irish convict prisons, 1877-95. Medical History, 58(1), 67-86.

Brown, A. (2003). English society and the prison: Time, culture and politics in the development of the modern prison. Woodbridge: Boydell.

Brown, A. (2013). Inter-war crime and penal policy in England: The Dartmoor convict prison riot, 1932. Basingstoke: Palgrave Macmillan.

Bruce, S. (2001). Fundamentalism and political violence: The case of Paisley and Ulster Evangelicals. Religion, 31(4), 387-405.

Bukovsky, V. (2003). Account of torture. In Being human: President's Council on bioethics. Washington, DC: President's Council.

Bynum, C. W. (1985). Fast, feast and flesh: The religious significance of food to medieval women. Representations, 11(Summer), 1-25. 
Callanan, F. (1996). T. M. Healy. Cork: Cork University Press.

Campbell, J. (2014). Roy Jenkins. London: Random House.

Carroll-Bourke, P. (2000). Colonial discipline: The making of the Irish convict system. Dublin: Four Courts Press.

Clark, E. B. (1995). 'The sacred rights of the weak': Pain, sympathy and the culture of individual rights in Antebellum America. Journal of American History, 82(2), $463-493$.

Clark, P. A. (2006). Medical ethics at Guantánamo Bay and Abu Ghraib: The problem of dual loyalty. Journal of Law, Medicine and Ethics, 34(3), 570-580.

Cole, D. (2005). Enemy aliens: Double standards and constitutional freedoms in the war on terrorism. London/New York: The New Press.

Coogan, T. P. (1994). The IRA: A history (p. 294). Niwot: Roberts Rinehart.

Cooter, R. (2003). The ethical body. In R. Cooter \& J. V. Pickstone (Eds.), Companion to medicine in the twentieth century (pp. 451-468). London: Routledge.

Costello, F. J. (1995). Enduring the most: The life and death of Terence MacSwiney. Kerry: Brandon Book Publishers.

Coveney, J. (2006 [2000]). Food, morals and meaning: The pleasure and anxiety of eating (2nd ed.). London: Routledge.

Crispin, E., \& Nathanson, V. (2013). Force feeding of mentally competent detainees at Guantánamo Bay. British Medical Journal, 347, 1-2.

Davis, M. (2009). Terrorists are just patients. American Journal of Bioethics, 9(10), 56-57.

Driscoll, C. (2002). Girls: Feminine adolescence in popular culture and cultural theory. New York: Columbia University Press.

Durbach, N. (2005). Bodily matters: The anti-vaccination movement in England, 1853-1907. Durham: Duke University Press.

Fanning, R. (2013). British government and Irish revolution 1910-1922. London: Faber and Faber.

Farrell, E. (2013). 'A most diabolical deed': Infanticide and Irish society, 18501900. Manchester: Manchester University Press.

Feldman, A. (2008). Formations of violence: The narrative of the body and political terror in Northern Ireland. Chicago: University of Chicago Press.

Ferber, S. (2013). Bioethics in historical perspectives. Basingstoke: Palgrave Macmillan.

Ferriter, D. (2012). Ambiguous republic: Ireland in the 1970s. London: Profile Books.

Fessler, D. M. T. (2003). The implications of starvation induced physiological changes for the ethical treatment of hunger strikers. Journal of Medical Ethics, $29,243-247$.

Fletcher, G. P. (2004). Black hole in Guantánamo Bay. Journal of International Criminal Justice, 2(1), 121-132. 
Flynn, B. (2011). Pawns in the game: Irish hunger strikes 1912-1981. Cork: Collins Press.

Foucault, M. (1977 [1975]). Discipline and punish: The birth of the prison. London: Penguin.

Francis, M. (2002). Tears, tantrums and bared teeth: The emotional economy of three conservative Prime Ministers. Journal of British Studies, 41(3), 354-387.

French, R. D. (1976). Antivivisection and medical science in Victorian Society. London: Princeton.

Fried, T. R., Stein, M. D., O'Sullivan, P., Brock, D. W., \& Novack, D. H. (1993). Limits of patient autonomy: Physician attitudes and practices regarding lifesustaining treatments and Euthanasia. Archives of Internal Medicine, 153(6), $722-728$.

Gatrell, V. A. C. (1994). The hanging tree: Execution and the English people, 1770-1868. Oxford: Oxford University Press.

Geddes, J. F. (2008). Culpable complicity: The medical profession and the forcible feeding of suffragettes 1909-14. Women's History Review, 17, 79-94.

Gesundheit, B., Ash, N., Blazer, S., \& Rivkind, A. I. (2009). Medical care for terrorists: To treat or not to treat? American Journal of Bioethics, 9(10), 40-42.

Godderis, R. (2006). Dining in: The symbolic power of food in prison. Howard Journal of Criminal Justice, 45(3), 255-267.

Gooldin, S. (2003). Fasting women, living women and hunger artists: Spectacles of body and miracles at the turn of a century. Body and Society, 9(2), 27-53.

Grant, K. (2011). British suffragettes and the Russian method of hunger strike. Comparative Studies in Society and History, 53(1), 113-143.

Grant, K. (2012). Fearing the danger point: The study and treatment of human starvation in the United Kingdom and India, c.1880-1974. In M. D. McCue (Ed.), Comparative physiology of fasting, starvation and food limitation (pp. 365-378). Berlin/New York: Springer.

Gregory, B. (2005). Hunger striking prisoners: The doctors' dilemma. British Medical Journal, 331, 866.

Gregory, D. (2006). The black flag: Guantánamo Bay and the space of exception. Geografiska Annaler, 88B(4), 405-427.

Grisard, D. M. (2015). The spectacle of the hunger-stricken body: A GermanItalian terrorist, Swiss prisons and the (ir)rational body politic. European Review of History, 22(1), 136-160.

Hamilton, S. (Ed.). (2004). Animal welfare and anti-vivisection 1870-1910: Nineteenth century women's mission. London/New York: Routledge.

Hanafin, P. (2000). D(en)ying narratives: Death, identity and the body politic. Legal Studies, 20(3), 393-408.

Hanley, B. (2002). The IRA, 1926-1936. Dublin: Four Courts Press.

Hannigan, D. (2010). Terence MacSwiney: The hunger strike that rocked an empire. Dublin: O’Brien Press. 
Hardy, A. (1995). Development of the prison medical service 1774-1895. In R. Creese, W. F. Bynum, \& J. Bearn (Eds.), The health of prisoners: Historical essays (pp. 59-82). Amsterdam: Rodopi.

Hart, P. (1998). The IRA and its enemies: Violence and community in Cork, 19161923. Oxford: Clarendon Press.

Hart, P. (2003). The IRA at war, 1916-1923. Oxford: Oxford University Press.

Hauser, G. A. (2000). Body rhetoric: Conflicted reporting of bodies in pain. In S. Chambers \& A. Costain (Eds.), Deliberation, democracy and the media (pp. 135-155). Lanham: Rowman and Littlefield Publishers.

Healy, J. (1982). The Civil War hunger strike: October 1923. Studies: An Irish Quarterly Review, 71, 213-226.

Hennessey, T. (1997). A history of Northern Ireland 1920-1996. London: Macmillan Press.

Hennessey, T. (1998). Dividing Ireland: World War One and partition. London/ New York: Routledge.

Hennessey, T. (2013). Hunger strike: Margaret Thatcher's battle with the IRA, 1980-1981. Dublin: Irish Academic Press.

Hepburn, J. R. (1984). The erosion of authority and the perceived legitimacy of inmate social protest: A study of prison guards. Journal of Criminal Justice, $12(6), 579-590$.

Hopkinson, M. (1988). Green against green: A history of the Irish Civil War. Dublin: Gill and Macmillan.

Hopkinson, M. (2002). The Irish War of independence. Dublin: Gill and Macmillan.

Hornblum, A. M., Newman, J. L., \& Dober, G. J. (2013). Against their will: The secret history of medical experimentation on children in Cold War America. Basingstoke: Palgrave Macmillan.

Howland, C. (2013). To feed or not to feed: Violent state care and the contested medicalization of incarcerated hunger strikers in Britain, Turkey and Guantánamo Bay. New Zealand Sociology, 28(1), 101-116.

Hunt, L. (2007). Inventing human rights: A history. London: W. W. Norton.

Ignatieff, M. (1978). A just measure of pain: The penitentiary in the industrial revolution, 1750-1850. London: Macmillan.

Ignatieff, M. (2005). The lesser evil: Political ethics in an age of terror. Edinburgh: Edinburgh University Press.

Jackson, M. (2013). The age of stress: Science and the search for stability. Oxford: Oxford University Press.

Jeffrey, K. (2000). Ireland and the Great War. Cambridge: Cambridge University Press.

Johns, F. (2005). Guantánamo Bay and the annihilation of the exception. European Journal of International Law, 16(4), 613-635.

Jones, J. H. (1992). Bad blood: The Tuskagee syphilis experiment. New York/ London: Free Press. 
Jonsen, A. R. (2000). A short history of medical ethics. Oxford/New York: Oxford University Press.

Kelly, S. (2013). Fianna Fáil, Partition and Northern Ireland, 1926-1971. Dublin: Irish Academic Press.

Kenney, M. A., Silove, D. M., \& Steel, Z. (2004). Legal and ethical implications of medically enforced feeding of detained asylum seekers on hunger strike. Medical Journal of Australia, 180, 237-240.

Kerndt, P. R., Naughton, J. L., Driscoll, C. E., \& Loxterkamp, D. A. (1982). Fasting: The history, pathophysiology and complications. Western Journal of Medicine, 137(5), 379-399.

Khan, M. (2008). My Guantánamo diary: The detainees and the stories they told me. New York: Public Affair Books.

Khodorkovsky, M. (2014). My fellow prisoners. London: Penguin Books.

King, J. F. (2011, March). The foundations of police unionism in the United Kingdom: The case of inspector John Syme. Law Enforcement Executive Forum, 173-187.

Laffan, M. (1999). The Resurrection of Ireland: The Sinn Féin party, 1916-1923. Cambridge: Cambridge University Press.

Lansbury, C. (1985). The old brown dog: Women, workers and vivisection in Edwardian England. Madison: University of Wisconsin Press.

Law, R. (2013). Terrorism: A history. Hoboken: Wiley.

Lederer, S. (1995). Subjected to science: Human experimentation in America before the Second World War. Baltimore: John Hopkins University Press.

Liddington, J., \& Norris, J. (1978). One hand tied behind us: The rise of the women's suffrage movement. London: Virago.

Liebling, A., \& Ward, T. (1995). Prison doctors and prison suicide research. In R. Creese, W. F. Bynum, \& J. Bearn (Eds.), The health of prisoners: Historical essays (pp. 118-133). Amsterdam: Rodopi.

Lifton, R. J. (2004). Doctors and torture. New England Journal of Medicine, $351(5), 415-416$.

Lowry, D. R. (1976). Internment: Detention without trial in Northern Ireland. Human Rights, 5(3), 261-331.

Maehle, A.-H. (2011). Medical ethics and the law. In M. Jackson (Ed.), The Oxford handbook of the history of medicine (pp. 543-560). Oxford: Oxford University Press.

Maguire, J. (2008). IR A internments and the Irish government: Subversives and the state, 1939-1962. Dublin: Irish Academic Press.

Mangham, A. (2007). Violent women and sensation fiction: Crime, medicine and Victorian popular culture. Basingstoke: Palgrave Macmillan.

Marks, J. H. (2007). Doctors as pawns? Law and medical ethics at Guantánamo Bay. Seton Hall Law Review, 37(3), 711-731.

Marks, J. H. (2009). The terrorist and the doctor: A legal and ethical response. American Journal of Bioethics, 9(10), 49-51. 
Martin, F. X. (1963). The Irish volunteers 1913-15: Recollections and documents. Dublin: James Duffey.

Mayhall, L. E. N. (2003). The militant suffrage movement: Citizenship and resistance in Britain. Oxford: Oxford University Press.

McAtackney, L. (2014). An archaeology of the troubles: The dark heritage of Long Kesh/Maze Prison. Oxford: Oxford University Press.

McConville, S. (1995). The Victorian prison: England, 1865-1965. In N. Morris \& D. J. Rothman (Eds.), The Oxford history of the prison: The practice of punishment in Western society (pp. 117-150). Oxford: Oxford University Press.

McGee, O. (2007). The IRB: The Irish republican brotherhood from the land league to Sinn Féin. Dublin: Four Courts Press.

McKee, W. (2009). Governor: Inside the maze. Dublin: Gill and Macmillan.

McKenna, J., Manzoor, F., \& Jones, G. (2009). Candles in the dark: Medical ethical issues in Northern Ireland during the troubles. London: Nuffield Trust.

McKittrick, D., \& McVea, D. (2012 [2000]). Making sense of the troubles: A history of the Northern Irish conflict. London: Viking.

Meehan, C. (2010). The Cosgrave Party: A history of Cumann na nGaedheal, 1923-33. Dublin: Royal Irish Academy.

Miles, S. H. (2007). Medical ethics and the interrogation of Guantánamo 063. American Journal of Bioethics, 7(4), 5-11.

Miller, I. (2009). Necessary torture? Digestive physiology, vivisection, the suffragette movement and responses to new forms of clinical practice in Britain, c.18701920. Journal of the History of Medicine and Allied Sciences, 64(3), 333-372.

Miller, I. (2011). A modern history of the stomach: Gastric illness, medicine and British Society, 1800-1950. London: Pickering and Chatto.

Miller, I. (2013). Constructing moral hospitals: Childhood health in Irish reformatories and industrial schools, c.1851-1890. In A. Mac Lellan (Ed.), Growing pains: Childhood illness in Ireland, 1750-1950 (pp. 105-122). Dublin: Irish Academic Press.

Miller, I. (2014). Reforming food in post-famine Ireland: Medicine, science and improvement, 1845-1922. Manchester: Manchester University Press.

Miller, I. (2015). Food, medicine and institutional life in the British Isles, c.17901900. In C. Helstosky (Ed.), The Routledge history of food (pp. 200-219). London: Routledge.

Miller, I. (2016). 'No hanging here': The persistence of the death penalty in twentieth-century Ireland. In L.-M. Griffith \& C. Wallace (Eds.), Grave matters: Death and dying in Dublin. Dublin: Four Courts Press.

Moen, D. (2000). Irish political prisoners and post-hunger strike resistance to criminalisation. In British Society of criminology conference: Select proceedings (Vol. 3, pp. 1-20).

Moore, J. (2007). Paramilitary prisoners and the peace process in Northern Ireland. In A. O'Day (Ed.), Political violence in Northern Ireland: Conflict and conflict resolution (pp. 81-94). London: Praeger. 
Moran, J. (2005). State power in the war on terror: A comparative analysis of the UK and USA. Crime, Law and Social Change, 44(4-5), 335-359.

Morrison, D. (2006). Hunger strike: Reflections on the 1981 Republican hunger strike. London: Brandon.

Morsink, J. (1999). The Universal declaration of human rights: Origins, drafting and intent. Philadelphia: University of Philadelphia Press.

Mulcahy, A. (1995). Claims-making and the construction of legitimacy: Press coverage of the 1981 Northern Irish hunger strike. Social Problems, 42(4), 449-467.

Murphy, W. (2007). Suffragettes and the transformation of political imprisonment in Ireland, 1912-1914. In L. Ryan \& M. Ward (Eds.), Irish women and the vote (pp. 114-135). Dublin: Irish Academic Press.

Murphy, W. (2013). Dying, death and hunger strike: Cork and Brixton, 1920. In J. Kelly \& M. A. Lyons (Eds.), Death and dying in Ireland, Britain and Europe: Historical perspectives (pp. 297-316). Dublin: Irish Academic Press.

Murphy, W. (2014). Political imprisonment and the Irish 1912-1921. Oxford: Oxford University Press.

Nic Dháibhéid, C. (2011). Seán MacBride: A republican life, 1904-1946. Liverpool: Liverpool University Press.

Nicosia, F. R., \& Huener, J. (Eds.). (2002). Medicine and medical ethics in Nazi Germany. New York/Oxford: Berghan Books.

Novick, B. (2001). Conceiving revolution: Irish nationalist propaganda during the First World War. Dublin: Four Courts Press.

O'Branski, M. A. (2014). 'The savage reduction of the flesh': Violence, gender and bodily weaponisation in the 1981 Irish Republican hunger strike protest. Critical Studies on Terrorism, 7(1), 97-111.

O'Halpin, E. (1999). Defending Ireland: The Irish state and its enemies since 1922. Oxford: Oxford University Press.

O'Keefe, D. (2011). Michael Ignatieff: The lesser evil? London/New York: Verso.

O'Malley, P. (1990). Biting at the grave: The Irish hunger strikes and the politics of despair. Belfast: Blackstaff Press.

O'Rawe, R. (2005). Blanketmen: An untold story of the H-Block bunger strike. Dublin: New Island.

O'Rawe, R. (2011). Afterlives: The hunger strike and the secret offer that changed Irish history. New York: Lilliput Press.

Oguz, N. Y., \& Miles, S. H. (2005). The physician and prison hunger strikes: Reflecting on the experience in Turkey. Journal of Medical Ethics, 31(3), 169-172.

Okie, S. (2005). Glimpses of Guantánamo: Medical ethics and the war on terror. New England Journal of Medicine, 353(24), 2529-2534.

Owens, R. C. (1984). Smashing times: A history of the Irish women's suffragette movement, 1889-1922. Dublin: Attic Press.

Passmore, L. (2012). The ethics and politics of force feeding terror suspects in West German prisons. Social History of Medicine, 25(2), 481-499. 
Patel, S. (2014). Racing madness: The terrorizing madness of the post-9/11 terrorist body. In L. Ben-Moshe, C. Chapman, \& A. C. Carey (Eds.), Disability incarcerated: Imprisonment and disability in the United States and Canada (pp. 201-216). Basingstoke: Palgrave Macmillan.

Pernick, M. S. (1985). A calculus of suffering: Pain, professionalism and anaesthesia in nineteenth-century America. New York: Columbia University Press.

Porter, R. (1978). Medical ethics: History of nineteenth-century Great Britain. In W. T. Reich (Ed.), Encyclopaedia of bioethics (Vol. 3). New York: Free Press.

Priestley, P. (1999 [1985]). Victorian prison lives: English prison biography, 1830-1914. London: Pimlico.

Prince, S. (2007). Northern Ireland's '68: Civil rights, global revolt and the origins of the troubles. Dublin: Irish Academic Press.

Proctor, R. N. (1988). Racial bygiene: Medicine under the Nazis. Cambridge, MA/London: Harvard University Press.

Pugh, M. (2002). March of the women: A revisionist analysis of the campaign for women's suffrage 1866-1914. Oxford: Oxford University Press.

Purdle, B. (1990). Politics in the streets: Origins of the civil rights movement in Northern Ireland. Belfast: Blackstaff Press.

Purvis, J. (1995). Prison experience of the suffragettes in Edwardian Britain. Women's History Review, 4, 103-133.

Rachels, J. (1997). Active and passive euthanasia. In N. S. Jecker, A. R. Jonsen, \& R. A. Pearlman (Eds.), Bioethics: An introduction to the history, methods and practice (pp. 77-82). London: Jones and Bartlett.

Radzinowicz, L., \& Hood, R. (1986). A history of English criminal law and its administration from 1750. London: Stevens.

Rae, J. (1970). Conscience and politics: The British government and the conscientious objector to military service, 1916-1919. Oxford: Oxford University Press.

Regan, J. M. (2013). The 'O'Brien ethic' as an interpretative problem. Journal of British Studies, 52(4), 908-939.

Richards, S. (1986). Drawing the life-blood of physiology: Vivisection and the physiologists' dilemma, 1870-1900. Annals of Science, 43(11), 27-56.

Rogan, M. (2011). Prison policy in Ireland: Politics, penal welfarism and political imprisonment. London: Routledge.

Rose, D. (2004). Guantánamo: America's war on human rights. London: Faber and Faber.

Ross, F. S. (2011). Smashing H-Block: The popular campaign against criminalisation and the Irish hunger strikes, 1976-1982. Liverpool: Liverpool University Press.

Rothman, D. (1975). Behaviour modification in total institutions. Hastings Center Report, 5(1), 17-24.

Rothman, D. J. (1991). Strangers at the bedside: A history of how law and bioethics transformed medical decision making. New York: Basic Books. 
Rubenstein, L. S. (2009). Medical ethics at Guantánamo Bay detention centre and in the US military: A time for reform. Lancet, 374, 353-355.

Rupke, N. A. (Ed.). (1987). Vivisection in historical perspective. London: Croom Helm. Russell, R. R. (2012). Nausea and vomiting: A history of signs, symptoms and sickness in nineteenth-century Britain (Unpublished $\mathrm{PhD}$ thesis). University of Manchester.

Showalter, E. (1987). The female malady: Women, madness and English culture, 1830-1980. London: Virago.

Sim, J. (1990). Medical power in prisons: The prison medical service in England 1774-1989. Milton Keynes/Philadelphia: Open University Press.

Sim, J. (1995). The prison medical service and the deviant, 1895-1948. In R. Creese, W. F. Bynum, \& J. Bearn (Eds.), The health of prisoners: Historical essays (pp. 102-117). Amsterdam: Rodopi.

Slahi, M. O. (2015). Guantánamo diary. New York: Little, Brown and Company.

Smith, B. A. (1982). The Irish prison system-Men in the middle, 1865-90. Medical History, 26(4), 371-394.

Smith, C. S. (2007). Bad men: Guantánamo Bay and the secret prisons. London: Weidenfeld and Nicolson.

Solis, G. D. (2010). The law of armed conflict: International humanitarian law in war. Cambridge: Cambridge University Press.

Spjut, R. J. (1986). Internment and detention without trial in Northern Ireland, 1971-1975: Ministerial policy and practice. Modern Law Review, 49(6), 712-739.

Sunshine, S. C. (1984). Should a hunger striker be allowed to die? Boston College Law Review, 25(2), 423-458.

Sweeney, G. (1993). Irish hunger strikes and the cult of self-sacrifice. Journal of Contemporary History, 28(3), 421-437.

Taylor, P. (1999). Loyalists. London: Bloomsbury.

Thornton, R. (2007). Getting it wrong: The crucial mistakes made in the early stages of the British Army's deployment to Northern Ireland (August 1969 to March 1972). Journal of Strategic Studies, 30(1), 73-107.

Todd, J. (2007). Through the darkness: A life in Zimbabwe. Cape Town: Zebra.

Tomkins, A. (2013). Workhouse medical care from working-class autobiographies, 1750-1834. In J. Reinarz \& L. Schwarz (Eds.), Medicine and the workhouse (pp. 86-102). Rochester: University of Rochester Press.

Turner, J. (1980). Reckoning with the beast: Animals, pain and humanity in the Victorian mind. Baltimore/London: John Hopkins University Press.

Valiulis, M. (2000). Neither feminist nor flapper: The ecclesiastical construction of the ideal Irish woman. In D. Urquhart \& A. Hayes (Eds.), The Irish women's history reader (pp. 168-178). London: Routledge.

Vernon, J. (2007). Hunger: A modern history. Cambridge, MA/London: Belknap Press. 
Vierucci, L. (2003). Prisoners of war or protected qua unlawful combatants? The judicial safeguards to which Guantánamo Bay detainees are entitled. Journal of International Criminal Justice, 1(2), 284-314.

Walker, G. (1992). 'The Irish Dr Goebbels': Frank Gallagher and Irish republican propaganda. Journal of Contemporary History, 27(1), 149-165.

Walker, R. K. (2008). The hunger strikes. Belfast: Lagan Books.

Walkowitz, J. (1980). Prostitution and Victorian society: Women, class and the state. Cambridge: Cambridge University Press.

Walsh, P. (1989). From civil rights to national war: Northern Ireland Catholic politics, 1964-74. Belfast: Athol Books.

Washington, H. A. (2006). Medical apartheid: The dark history of medical experimentation on Black Americans from colonial times to the present. New York: Anchor Books.

Wee, L. (2007). The hunger strike as a communicative act. Journal of Linguistic Anthropology, 17(1), 61-76.

Weiner, M. J. (1994). Reconstructing the criminal: Culture, law and policy in England, 1830-1914. Cambridge: Cambridge University Press.

Weiner, M. J. (1995). The health of prisoners and the two faces of Benthamism. In R. Creese, W. F. Bynum, \& J. Bearn (Eds.), The health of prisoners: Historical essays (pp. 44-58). Amsterdam: Rodopi.

Welch, M. (2009). Guantánamo Bay as a Foucauldian phenomenon: An analysis of penal discourse, technologies and resistance. Prison Journal, 89(1), 3-20.

Welsh, J. (2002). The problem of torture. In M. Peel \& V. Lacopino (Eds.), The medical documentation of torture (pp. 1-19). London: Greenwich Medical Media.

White, R. W. (1989). From peaceful protest to Guerrilla War: Micro-mobilization of the provisional Irish Republican Army. American Journal of Sociology, 9(6), 1277-1302.

White, R. W. (1999). Comparing state repression of pro-state vigilantes and antistate insurgents: Northern Ireland, 1972-75. Mobilization: An International Quarterly, 4(2, Fall), 189-202.

White, P. (2006). Sympathy under the knife: Experimentation and emotion in late Victorian medicine. In F. B. Alberti (Ed.), Medicine, emotion and disease 1700-1950. Basingstoke: Palgrave Macmillan.

Wilcox, L. (2011). Dying is not permitted: Sovereignty, biopower and force feeding at Guantánamo Bay. In S. Biswas \& Z. Zalloua (Eds.), Torture, power, democracy and the human body (pp. 101-128). Washington, DC: University of Washington Press.

Wilks, M. (2006). Guantánamo: A call for action: Doctors and their professional bodies can do more than you think. British Medical Journal, 332, 560-561.

Williams, E. A. (2007). Neuroses of the stomach: Eating, gender and psychopathology in French medicine. Isis, 98, 54-79. 
Williams, E. A. (2008). Gags, funnels and tubes: Forced feeding of the insane and of suffragettes. Endeavour, 32, 134-140.

Williams, E. A. (2010). Stomach and psyche: Eating, digestion and mental illness in the medicine of Phillipe Pinel. Bulletin of the History of Medicine, 84(3), $358-386$.

Wills, C. (2008). That neutral Island: A history of Ireland during the Second World War. London: Faber.

Wilson, R. J. (2003). United State detainees at Guantánamo Bay: The InterAmerican Commission on human rigs respond to a 'legal black hole'. Human Rights Brief, 10(3), 2-5.

Wilson, D. (2013). What can history do for bioethics? Bioethics, 27(4), 215-223.

Wilson, D. (2014). The making of British bioethics. Manchester: Manchester University Press.

Wisnewski, J. J. (2010). Understanding torture. Edinburgh: Edinburgh University Press.

Worthington, A. (2009). Guantánamo's hidden history: Shocking statistics of starvation. London: Cageprisoners.

Yin, T. Y. (2010). 'Anything but Bush?': The Obama administration and Guantánamo Bay. Harvard Journal of Law and Public Policy, 34(2), 453-492.

Yuill, C. (2007). The body as weapon: Bobby sands and the Republican hunger strikes. Sociological Research Online, 12(2). 